\title{
A construção do imaginário urbano no documentário brasileiro contemporâneo
}

Tese apresentada ao Programa de Pós-Graduação em Ciências da Comunicação, na área de Estudo dos Meios e da Produção Mediática, da Escola de Comunicações e Artes da Universidade Estadual de São Paulo, como requisito parcial para obtenção do Título de Doutor, sob a orientação da Prof. Dra. Maria Dora Genis Mourão.

São Paulo 


\section{A construção do imaginário urbano documentário brasileiro contemporâneo}

Tese apresentada ao Programa de Pós-Graduação em Ciências da Comunicação, na área de Estudo dos Meios e da Produção Mediática, da Escola de Comunicações e Artes da Universidade Estadual de São Paulo, como requisito parcial para obtenção do Título de Doutor, sob a orientação da Prof. Dra. Maria Dora Genis Mourão.

São Paulo 
Banca Examinadora 
A Clara e ao Júnior 


\section{Resumo}

Este trabalho investiga documentários brasileiros contemporâneos sob a perspectiva da inscrição dos imaginários urbanos engendrados em suas formas de narrar as cidades brasileiras, convocando três filmes, realizados no século XXI: Edifício Master, Ônibus 174 e Rua de mão dupla. No desenvolvimento de nossa análise, partimos da percepção do documentário como encontro maquínico instaurador de dispositivos técnicos e conceituais, nutrindo-se de um imaginário coletivo ao mesmo tempo em que a ele incorpora-se como imagem. Posto isso, desenvolvemos a hipótese de que os dispositivos de interação empregados pelos documentaristas configuram sociabilidades documentais, moduladas em relações de proximidades e distâncias que acabam, a um só tempo, por expressar o estar junto nas imagens, bem como espelhar (e modular) o contexto de onde elas partem. Tais sociabilidades são formas de partilha e de relações narrativas que se abrem à fabulação criadora ou que, ao contrário, tentam domesticá-la em proveito de um efeito de veracidade. Com esses pressupostos, preocupamonos em analisar pormenorizadamente os três filmes acima citados, notando que as diferentes formas de sociabilidade documental acabavam por agenciar distintas inscrições do imaginário urbano brasileiro.

Palavras-chave: documentário; sociabilidade documental; dispositivos de interação; cidade; estilo narrativo. 


\begin{abstract}
This thesis examines Brazilian contemporary documentaries from the perspective of the urban imaginaries insertion engendered in the form they narrate Brazilian cities, convoking three films made in the $21^{\text {st }}$ century: Edificio Master, Ônibus 174 e Rua de mão dupla. In developing our analysis, our starting point is the conception of documentary film as an encounter towards camera that establishes technical and conceptual dispositives, nourishing itself from collective imaginary and at the same time incorporating itself in it as image. That stated, we develop the hypothesis that interaction dispositives employed by documentary filmmakers form documental sociabilities, modulated in their relation of proximity and distance, which not only express the beingtogether in the images, but also mirror (and modulate) the context from which they start out. These sociabilities are forms of sharing and narrative relations that open themselves to creative fabulation or that, in a contrary way, try do domesticate it in benefit of a veracity effect. Having these presuppositions in mind, our concern is to analyze in detail the three films above mentioned, noting that the different forms of documental sociability set different insertions of Brazilian urban imaginary.
\end{abstract}

Key-words: Documentary; documental sociability; interaction dispositives; city; narrative style. 
1. A CIDADE IMAGINÁRIA E A SOCIABILIDADE DOCUMENTAL .......................14

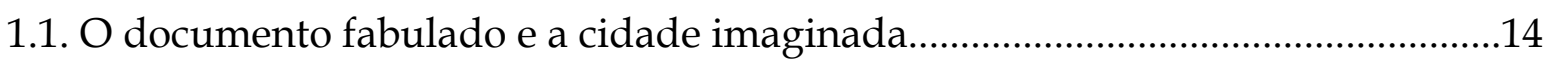

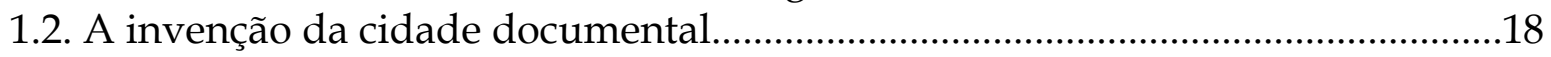

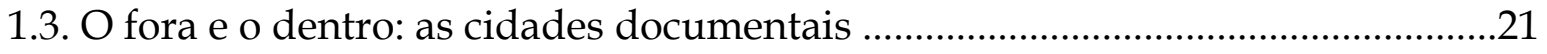

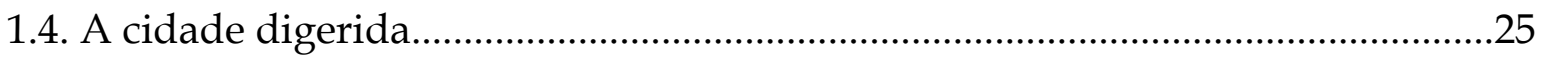

1.5. O documentário como encontro e a inscrição da cidade na sociabilidade documental

\section{PROXIMIDADES E DISTÂNCIAS NA CONSTRUÇÃO DAS CIDADES}

DOCUMENTAIS

2.1. A inscrição do tempo urbano no espaço narrativo.

2.2. Prévias de Primárias: o encontro de Robert Drew, Richard Leacock, D.A.

Pennebaker e Albert Maysles . .43

2.3. Primárias: a cidade observada e a sociabilidade distanciada. .48

2.4. Prévias de Crônica de um verão: o encontro de Morin e Rouch.

2.5. Crônica de um verão: a cidade do encontro/confronto e a sociabilidade partilhada....

2.6. Sociabilidades documentais urbanas: o objetivo-orgânico e o imaginário-cristal na narração das cidades 83

3. DISPOSITIVOS DE INTERAÇÃO .87

3.1. A integração dos dispositivos de interação no Brasil

PARTE II

Os dispositivos de interação e a construção do imaginário urbano nos documentários contemporâneos

\section{EDIFÍCIO MASTER: O JOGO DA SOCIABILIDADE E A CIDADE FANTÁSTICA}

4.1. Um filme de visitas

4.2. A polifonia dos vazios

4.3. A palavra encarnada

5. ÔNIBUS 174: A SOCIABILIDADE DISTANCIADA E A CIDADE VISÍVEL

5.1. A palavra desencarnada e o dogma da objetividade 
5.4 A cidade, Sandro, os meninos de rua e a mídia como personagens

6. RUA DE MÃO DUPLA: A SOCIABILIDADE ÀS AVESSAS E A CIDADE DO OUTRO

6.1. A cidade interior .184

6.2. Um filme de espelhamentos 190

CONCLUSÃO 205

BIBLIOGRAFIA 209

FILMOGRAFIA 216 


\section{INTRODUÇÃO}

Para concebermos a relação entre documentário e cidade, gostaríamos de evocar, a princípio, o imaginário urbano, esse grande patrimônio de imagens que encerram a atmosfera do estar na cidade, vivê-la e compartilhá-la. Em registros de visibilidades, as cidades contemporâneas já não podem ser dissociadas dos plurais e ininterruptos fluxos de imagens que as constituem ao mesmo tempo em que são constituídos por elas em um jogo intercambiável e permanente. A cultura visual, bem sabemos, integra nossos sentidos e afirma-se como prótese e extensão dos habitantes citadinos neste século XXI. Entretanto, a consciência dessa condição imagética na qual estamos submersos independe dos bens materiais que possamos ter, pois trata-se da presença simbólica, da formatação dos padrões culturais e sociais exacerbados nos fluxos cotidianos.

Nesse sentido, preocupação fundamental da escolha da cidade, para a reflexão acerca dos documentários brasileiros contemporâneos, é a de perceber como as narrativas produzidas por caminhos diversos $\mathrm{e}$ independentes dos discursos midiáticos afirmam sua singularidade nas formas de inscrição das cidades brasileiras. Narrativas estas que, em seu conjunto, nos remetem a diferentes formas dos documentaristas olharem, imaginarem e construírem a cidade em inter-relação com o mundo registrado.

Edificio Master (2002), de Eduardo Coutinho, Ônibus 174 (2002), de José Padilha e Felipe Lacerda, e Rua de mão dupla (2002), de Cao Guimarães, 
trazem, cada um a seu modo, originalidades estéticas, ao mesmo tempo em que colocam em cena as possibilidades do cinema de inscrever múltiplos imaginários urbanos, através dos seus dispositivos de interação e partilha com o outro. São filmes que, na impureza de suas práticas documentais, estabelecem diálogos afinados não apenas com a tradição do cinema moderno, mas também com a televisão e com as artes do vídeo, tomadas aqui em acepção ampla.

Pensar no documentarista como um sujeito urbano que atualiza, recria e inventa em seu dia a dia a memória e a história da cidade é, a um só tempo, circunscrever o lugar de onde parte o gesto cinematográfico na documentação em contexto urbano contemporâneo e propor a dimensão em que o testemunho no documentário é, também ele, contaminado pelo espírito de fabulação e de invenção.

Tomando como premissa uma cidade documental atravessada por múltiplas imaginações - a saber: a do realizador, de suas personagens e do espectador -, o Capítulo 1 problematiza o encontro documental. A cidade do documentarista é simultaneamente a de sua experiência cotidiana e também aquela nascida do encontro maquínico entre ele e suas personagens. Esse encontro não apenas engendra o acontecimento narrativo, mas também estabelece, em suas relações de proximidade e distância, uma certa sociabilidade documental.

O Capítulo 2 resgata a gênese dessa sociabilidade documental como configuradora de uma estética urbana que, segundo entendemos, tem sua 
origem no documentário moderno. Os filmes-manifestos Crônica de um verão (Chronique d'un été, 1961), de Jean Rouch e Edgard Morin, e Primárias (Primary, 1960), de Robert Drew e Richard Leacok, trazem elementos estéticoconceituais que acreditamos possuir importantes desdobramentos para a reflexão acerca da produção das imagens documentais contemporâneas. São filmes que afirmam a presença do realizador em inter-relação com as personagens. Seja uma presença diante das câmeras, exercitando a arte da palavra no jogo de partilha e interação, (como reza a tradição do cinema verdade), seja uma presença-ausente, configurando-se como um observador discreto que compartilha o evento registrado de acordo com o princípio da não-intervenção, como quer a tradição do cinema direto norte-americano. Esses diferentes princípios de compartilhamento do espaço narrativo com o outro constituem sociabilidades documentais que acabam por inscrever diferentes imaginários urbanos nas relações de filmagem.

Atualizando tais reflexões ao contexto nacional, lançamos no capítulo 3 o olhar a uma trajetória específica do documentário brasileiro dos anos 60 até hoje, pontuando alguns momentos que consideramos relevantes na documentação das cidades, e focalizando nossa atenção aos dispositivos de interação com o outro na construção do imaginário urbano. Há um diálogo intenso entre o cinema, a televisão, o vídeo independente e, mais recentemente, a vídeo-arte; e ele acompanha o percurso e as transformações do documentário nacional. Pensar acerca de tais passagens e rupturas da estética/ética documental, ocorridas entre os anos 60 e o século XXI, ajuda a 
situar as filiações dos documentaristas e de suas obras.

Considerando ainda a sociabilidade documental como configuradora de dispositivos de interações, materiais e simbólicas, a segunda parte deste trabalho dedica-se às análises de Rua de mão dupla, Edifício Master e Ônibus 174, buscando definir qual estética de cidade inscrevem eles em seus diferentes métodos de entrevista e de incursão ao mundo do outro. Edifício Master, em seu diálogo com a tradição do cinema verdade, no desenvolvimento de sua partilha da intimidade, constrói uma cidade ausente, evocada pelas imagens desde dentro do prédio e pelas fabulações de suas personagens. Originalmente uma vídeo-instalação, Rua de Mão Dupla compactua com o filme de Coutinho no sentido de que a cidade também aparece às avessas, do interior dos apartamentos e das personagens, embora neste caso não falem de um bairro ou de uma cidade, mas do outro. Apesar de ser a cidade sugerida pelas vistas de paisagens que as personagens, portadoras de câmeras, fazem das janelas de seus anfitriões ausentes, é precisamente da estética metropolitana do relacionar-se com o diferente que mais emerge o espírito urbano.

Todavia, se esses dois filmes apresentam a cidade interior, Ônibus 174 faz ressoar o imaginário do espaço público. Padilha e Lacerda envolvem as imagens de arquivo do seqüestro captadas por câmeras de televisão e de vigilância da Companhia de Energia de Tráfego (CET/RJ) em uma série de depoimentos, para redesenhar o imaginário de uma cidade violenta como resposta à produção de invisibilidades da vida contemporânea. 
Enfim, ao desenvolvermos a tese de que, a partir do documentário moderno, inauguram-se dispositivos de interação configuradores de sociabilidades documentais que se atualizam e se desdobram nas narrativas contemporâneas, acreditamos reafirmar o documentário como a arte do encontro, bem como o lugar privilegiado da inscrição de diferentes imaginários da vivência nas cidades brasileiras no século XXI. 


\section{PARTE I}




\section{A CIDADE IMAGINÁRIA E A SOCIABILIDADE DOCUMENTAL}

Não há mundo pronto para ser visto, um mundo antes da visão, ou antes, da divisão entre o visível (ou pensável) $e$ o invisivel (ou pressuposto) que institui o horizonte de um pensamento.

Eduardo Viveiro de Castro

\subsection{O documento fabulado e a cidade imaginada}

Se for fato que os documentários dialogam com as imagens do mundo, arriscamos dizer que eles também criam mundos e que em suas realizações a imaginação torna-se tão essencial quanto a observação. É nessa perspectiva que podemos pensar que Rua de mão dupla (2002), de Cao Guimarães, Edifício Master (2002), de Eduardo Coutinho, e Ônibus 174 (2002), de José Padilha e Felipe Lacerda revelam tanto ou mais a forma dos documentaristas olharem, imaginarem e construírem audiovisualmente as realidades do que elas próprias, tornando esse gesto criador também da ordem do sensível. É propositalmente que falamos em 
construção e criação; para endossar a idéia de que o documentário, longe de estar a serviço de uma história objetiva e hipostasiada, só pode ser pensado em seus atravessamentos pela imaginação. Tanto a imaginação criadora do documentarista, como aquela em que a obra encontra o espectador.

Em cotejo a essa concepção, do documentário como fabulação e recriação de um mundo, convocamos Bill Nichols, ${ }^{1}$ que o concebe como uma representação do mundo histórico traçando uma dicotomia entre esse e o mundo imaginário, ou ainda, o mundo imaginado pelo cineasta que acredita ser acionado, sobretudo, no campo da ficção. Partindo dessa concepção, Nichols propõe uma taxionomia identificando modos de representação da realidade que dariam conta de classificar formas que adquirem o encontro documental em suas possíveis combinações. Concordamos com o autor no sentido de acreditar que o documentário efetivamente se refere a um encontro do realizador com o mundo histórico, mas observamos que para nós é impossível estabelecer, no espaço narrativo ou mesmo fora dele, um princípio dicotômico entre esse e o regime imaginário.

A idéia, portanto, a que nos filiamos, é de que o real é atravessado pelo imaginário, assim como o imaginário nutre-se do real em um jogo de espelhamentos e duplicidades. Regimes de imagens que dialogam e se complementam em um trajeto antropológico na assimilação, acomodação e criação das imagens como nos mostra a

\footnotetext{
${ }^{1}$ Cf. Introdução ao documentário. Campinas: Papirus, 2005. p. 135. Nessa obra, Nichols revisa e amplia os modos de representação elaborados em La representación de la realidad: cuestiones y conceptos sobre el documental. Barcelona: Paiadós Comunicación, 1991.
} 
obra de Gilbert Durand.2 O imaginário, talvez seja importante precisar, como "algo que ultrapassa o indivíduo e que impregna o coletivo"3.

Assim, no nosso entender, as construções narrativas dos documentários urbanos delineiam arranjos singulares das cidades brasileiras atravessados pelos imaginários dos seus realizadores e pela maneira através da qual optam contar suas histórias. São pedaços de mundo, tal a noção de paisagem em Simmel, arrancados de um todo qualquer e adquirindo, com seu destaque e diferenciação, um status de ponto de vista estético e atmosférico. ${ }^{4}$ Dessa perspectiva, podemos falar que os documentários que iremos analisar narram realidades que existem nas imagens e que nascem com elas. $\mathrm{O}$ ato narrativo torna-se, portanto, um jogo de articular peças, onde o realizador propõe uma forma possível de inscrever a cidade nas imagens audiovisuais.

Comolli, em ensaio acerca da cidade filmada 5 afirma que

bem longe de copiar o mundo a imagem se contenta em produzi-lo como imagem. Nem reprodução, nem duplicação, a imagem é evidentemente este 'original', ela já é esta primeira inscrição que racha a imagem do mundo 6 .

\footnotetext{
2 Cf. DURAND, Gilbert. As estruturas antropológicas do imaginário. São Paulo: Martins Fontes, 2002. p.29. Segundo o autor, o trajeto antropológico "é a incessante troca que existe em nível imaginário entre as pulsões subjetivas e assimiladoras e as intimidações objetivas que emanam do meio cósmico e social".

${ }^{3}$ MAFFESOLI, Michel. O imaginário é uma realidade. Revista da Famecos, Porto Alegre:PUCRS, p.76, ago. 2001,

${ }^{4}$ SIMMEL, George. A filosofia da paisagem. Política e Trabalho, v. 12, p.15, 1996.

${ }^{5}$ COMOLLI, Jean-Louis. A cidade filmada. In: Cadernos de Antropologia e Imagem. v. 4: A cidade em imagens. Rio de Janeiro: UERj, 1997. p. 152.

${ }^{6}$ Op.cit. p.164-165.
} 
Aderimos, portanto, à sua noção de cidade filmada, uma cidade inaugurada nas imagens em íntima inter-relação com o olhar que a apreende. Dessa maneira “a cidade do cineasta tem mais chances de existir nos filmes do que em outros lugares"7 à medida que é (re)inventada nas imagens, constituída pelo gesto criador do documentarista em inter-relação com as pessoas e lugares que elege como pedaços de mundo e que ao mundo retornam como imagens. Um pedaço de mundo que nos olha, segundo Comolli, tomando-nos como sujeitos do olhar, colocando-nos no poder do olhar do outro. Possibilitando a nós, espectadores, olhar a cidade através do olhar do documentarista, de seu "mundo simbólico e criativo" ${ }^{8}$

Portanto, a noção que defendemos aqui é de uma cidade modulada por fluxos da ordem do sensível que impregnam o gesto cinematográfico, os encontros do documentarista-câmera com o mundo ao qual se aproxima, bem como a instância da fruição do espectador com a obra, ela mesma configurando um outro estatuto de encontro e confronto. Percepção que nos remete à Andréa França em seu pressuposto da imagem cinematográfica como "escrita do pensamento, uma lógica do sensível em imagem". Premissa que se contrapõe à idéia do cinema “como mera representação, analogia ou reprodução" já que relativiza a pretensão de uma equivalência entre obra e mundo captado, colocando-a em um regime de atravessamentos imaginários, criativos e sempre negociados entre filmados e filmantes. A autora intui, em seu diálogo com Maurice Blanchot, que

\footnotetext{
${ }^{7}$ Idem. Ibidem.

${ }^{7}$ ECKERT, Cornélia; ROCHA, Ana Luiza Carvalho. Lês enjeux du temps moderne: ville et cinéma. Premières rencontres anthropo-cinematographiques de Besançon. Besançon: Presses Universitaires FrancComtoises, 2002.
} 
se a narrativa é errância e encontro inacabado, lugar onde nos instalamos em um devir, ela deve ser assimilada à imagem dos começos, imagem que participa da criação dos mundos. ${ }^{9}$

Percebemos a cada narrativa documental, portanto, não uma continuidade, mas ela mesma como uma origem de atualização de uma realidade, com toda a carga de (re)criação que isso implica.

\subsection{A invenção da cidade documental}

Ao descrever a experiência urbana na literatura, Paulo Cordeiro Gomes ${ }^{10}$ propõe pensar a cidade como um discurso, como uma linguagem pulsante e dinâmica que se oferece ao habitante, ele também percebido como um ser-linguagem em seu ato de vivê-la e nela produzir significados incessantemente. É nesse campo que se situa o documentarista urbano e sua obra, que acaba por engendrar formas narrativas para uma realidade dinâmica e sempre móvel. ${ }^{11}$ Mapear a cidade em sua multiplicidade de sentidos e de "suas múltiplas vozes e grafias é uma operação poética que procura apreender a escrita da cidade e a cidade como escrita, num jogo aberto à complexidade", 12 diz Gomes.

\footnotetext{
${ }^{9}$ FRANÇA, Andréa. Terras e fronteiras no cinema político contemporâneo. Rio de Janeiro: 7 Letras, 2003. p. 131.

10 GOMES, Renato Cordeiro. Cartografias urbanas: representações da cidade na literatura urbana. Revista Semear, n. 1. Cátedra Pe. António Vieira de estudos portugueses. PUC/RIO. Disponível em: <http://www.letras.puc-rio.br/Catedra/revista/semiar_1.html>.

${ }^{11}$ Idem. Ibidem.

12 Idem. Ibidem. Grifos meus.
} 
A cidade se oferece como narrativa a ser descoberta, desvendada, recriada pela vivência pessoal e coletiva de seus habitantes.

Quando observamos o espaço, ruas, edifícios, nós visualizamos e 'produzimos' um espaço diferente do real, um espaço simbólico. Este espaço novo, resultado da observação e de uma visualização influenciada pela vivencia da cidade, é, de certa forma, o espaço real. ${ }^{13}$

Com De Certeau ${ }^{14}$ acrescentaria que esse sempre renovado espaço é fruto da atualização do homem ordinário, verdadeiro narrador do cotidiano que nas suas práticas diárias reinventa incessantemente a vida urbana das cidades brasileiras. Assim, integrando os fluxos de imagens da contemporaneidade, os documentários desenham cartografias a um só tempo pessoais e coletivas das cidades que narram. Cartografias onde se cruzam o imaginário do realizador, “a memória da cidade e a cidade da memória". 15

Nessa dinâmica da razão e do sensível entendemos, com Aumont, que fazer uma imagem é apresentar o equivalente a um "campo visual e campo fantasmático, e os dois a um só tempo, indivisivelmente". ${ }^{16}$ Pontos de vistas que compõem significados ao mundo que o documentarista imagina, observa e interage. E, nesse sentido, “o filme representa um mundo imaginário que ele representa pra nós nas formas de um substituto, de um significante ele próprio imaginário". ${ }^{17} \mathrm{O}$

\footnotetext{
${ }^{13}$ Op.cit., p.84. Grifo meus.

${ }^{14}$ CERTEAU, Michel de. A invenção do cotidiano. v. 1 e 2. Petrópolis: Vozes, 1994.

${ }^{15}$ Idem, Ibidem.

${ }^{16}$ AUMONT, Jacques. O olho interminável (cinema e pintura). São Paulo: Cosac\&Naify, 2004. p. 114.

17 Op.cit. p. 153.
} 
documentário entendido, portanto, segundo a perspectiva de Aumont, como uma "máquina simbólica de produzir pontos de vista", todos os pontos de vista imagináveis, aqueles do imaginário. ${ }^{18}$

Rua de mão dupla, Edifício Master e Ônibus 174 inscrevem diferentes formas dos documentaristas olharem, imaginarem e construírem a cidade em inter-relação com suas personagens. Ao apresentarem formas diversas de falar dos fenômenos urbanos, tornam-se portas de acesso a maneiras de compartilhar, com o espectador, outros imaginários possíveis dos cotidianos e dos habitantes das cidades brasileiras. Mesmo em se tratando de eventos excessivamente midiatizados como em Ônibus 174, esses filmes têm como norte atuar como uma caixa de ressonância ${ }^{19}$ das produções das grandes redes de comunicação, geralmente mais comprometidas com visões totalizantes e consensuais da realidade.

Como intenção, eles operam em chave alternativa às obras audiovisuais das emissoras comerciais de televisão, embora Ônibus 174, por exemplo, mesmo querendo propor um olhar mais adensado e diferenciado àquele que pautou a transmissão ao vivo do seqüestro, enrede-se em estratégias muito similares à grande mídia, utilizando recursos narrativos para endossar clichês da imagem como prova do real. Contudo, Edifício Master e Rua de mão dupla, em suas propostas estéticoconceituais, acabam por evidenciar toda uma pedagogia do olhar na contramão dos assujeitamentos dos grandes discursos mídiaticos que costumam reduzir o espaço urbano a um lugar onde as personagens ocupam lugares emblematizados e préconcebidos (o pobre, o classe média, o negro, a prostituta, etc.).

\footnotetext{
${ }^{18}$ Op.cit. p. 77.

19 Comolli propõe que o cinema é uma ferramenta de pensamento, o livro da história, a memória da crítica do mundo como olhar.Cf. Op. cit. p. 182.
} 
Engendra-se aí uma partilha entre o espectador e a pluralidade de imaginários que se apresentam nessas narrativas documentais acionando toda uma sensibilidade em relação à diversidade urbana. Podemos pensar, por essa ótica, que nesse encontro com o público, constitui-se um terceiro espaço de enunciação simbólica. ${ }^{20}$ Espaço que não sendo nem aquele da narrativa, nem aquele do espectador, inclui os dois para formar um terceiro: desestabilizador, híbrido e intersticial. Acreditamos ser nele que as imagens urbanas se conformam e se recompõem, mobilizando um lugar onde a narrativa assume sua riqueza semântica e sua instabilidade de sentidos. Assim, as cidades brasileiras propostas nesses filmes nascem nesse entre-lugar e se formatam em uma dinâmica frágil, instável e potente como é a imaginação.

\subsection{O fora e o dentro: as cidades documentais}

Com suas diferentes formas de narrar Rua de mão dupla e Edifício Master articulam o imaginário da cidade desde o interior dos apartamentos; neles a cidade está lá fora, no extracampo, desenhando-se de maneira sugerida e quase sempre ausente. Já Ônibus 174 articula seu desenho narrativo pautando-se na visibilidade do espaço urbano apresentadas, a maior parte do tempo, com os offs dos entrevistados.

\footnotetext{
${ }^{20}$ Essa expressão é emprestada de Homi Bhabha, que, em suas análises da desterritorialização e identidade das culturas diaspóricas, propõe que elas se delineiam em um terceiro espaço de enunciação simbólica. Espaço impuro e indeterminado que "embora em si irrepresentável, constitui as condições discursivas de enunciação que garantem que o significado e os símbolos da cultura não tenham unidade nem fixidez primordial e que até mesmo os signos possam ser apropriados, traduzidos, re-historizados e lidos de outro modo". Cf. BHABHA, Homi. O local da cultura. Belo Horizonte: Editora UFMG, 1998. p. 68.
} 
São filmes que esboçam, cada um a seu modo, uma cidade que a um só tempo leva ao espectador a possibilidade de vivenciar um efeito de alteridade com o outro e uma certa sensação de violência inerente à vida na metrópole. Violência por imagens abjetas como em Ônibus 174, pela solidão que cerca as personagens de Edifício Master ou mesmo na intolerância ao diferente e à diferença presente em Rua de mão dupla.

Edificio Master mostra uma cidade fabulada que se faz presente através dos relatos e rememorações de alguns moradores. Como reza a tradição de Eduardo Coutinho, o documentário se estrutura a partir de "conversas", sendo a maior parte delas dentro dos apartamentos conjugados (quarto e sala) do Master, locação única das gravações. A voz e/ou a figura do realizador estão quase sempre presentes no espaço cinemático reforçando a filosofia do encontro adotado pelo realizador. As personagens têm uma única aparição, o que as desvincula com um antes ou depois, ${ }^{21}$ valorizando o presente do acontecimento, o momento e as circunstâncias da entrevista. Entre uma conversa e outra há imagens intersticiais que tanto podem ser os bastidores da filmagem de Coutinho e sua equipe perambulando de um lado a outro, como também sequências de vazios: o interior dos apartamentos, as janelas, os corredores e outros espaços de circulação do prédio.

As imagens capturadas pelas câmeras de vigilância do Edifício Master e agenciadas na montagem do filme adquirem maior densidade narrativa em contraponto aquelas intersticiais às entrevistas, permeadas de silêncios e vazios. Arranjo visual que retumba em alguns depoimentos que evocam a presença de um ambiente violento, caótico e fraturado socialmente povoando tanto o interior do prédio como o local onde ele se situa, a imaginária Copacabana (que só se faz 
presente como uma "figura de ausência"22). É também através das imagens de controle que vemos, na cena inicial e por uma única vez, a imagem da cidade, da calçada, do trânsito. Cena que narra a chegada de Coutinho e de parte de sua equipe ao local da filmagem em diálogo afinado com a política reflexiva ${ }^{23}$ inaugurada em Cabra marcado para morrer, 1964-1984.

É de forma mais sutil que percebemos a presença da cidade em Rua de mão dupla, onde o próprio nome já remete ao espaço público, lugar das vivências cotidianas e confronto com a diferença e o diferente, temática que o documentário desenvolve desde o interior dos apartamentos. O dispositivo desenvolvido por Cao Guimarães é aparentemente simples: pessoas que moram sozinhas e que não se conhecem trocam de casa por 24 horas, portando uma câmera de vídeo, uma fita de gravação com duração de 60 minutos e total liberdade para registrar o que quisessem uma na casa da outra. Ao final desse período cada participante, a partir do que viu e vivenciou, relata sua experiência de estrangeiro e tenta traçar uma imagem mental do outro, imaginar suas características e arriscar se teria ou não afinidades com ele. Despontam aí personalidades eminentemente urbanas em suas formas de olhar e falar sobre o outro.

Apesar da paisagem da cidade aparecer nas imagens que os "invasores" três duplas, divididas em três blocos - fazem com suas câmeras das janelas dos apartamentos ou na evocação acerca do lugar que registram, são nos depoimentos que dão ao diretor Cao Guimarães que o espírito do viver na metrópole fica mais evidenciado: no desenho dos retratos falados, no confronto das suposições

\footnotetext{
${ }^{22}$ Cf. VERNET, Marc. De l'invisible au cinema: figures de l'absence. Paris: Cahiers du cinéma, 1988.

${ }^{23}$ STAM, Robert. Introdução à teoria do cinema. Campinas: Papirus, 2000. p. 174-176.
} 
(imaginárias) de um sobre o outro e, sobretudo, na forma metropolitana de perceber o outro. O estranhamento, a repulsa e até mesmo a indiferença ao diferente remetem o espectador aos preconceitos e intolerâncias características que formatam os laços sociais nas grandes cidades.

Esse estranhamento é incorporado pela própria estética do documentário que desestabiliza o lugar do espectador propondo uma narrativa pouco convencional. Ainda que se aproxime dos modelos dos reallitys shows em chave de "troca de casas", Rua de mão dupla desloca e subverte o show da visibilidade, característico dos programas televisivos, insistindo na estranheza de seus registros. Em parte, por migrar de uma videoinstalação onde o corpo e a percepção do espectador eram provocados por duas telas simultâneas, com informações distintas, dispostas separadamente no espaço. Interessante que no movimento de desterro a um formato tradicional de exibição ela mantém o princípio que lhe originou subdividindo a tela em dois espaços, onde podemos assistir, concomitantemente, os relatos videográficos das duas personagens em estética precária e amadora.

Ônibus 174 traz a cidade vista de cima, do ponto de vista aéreo e distanciado, o que lhe dá uma perspectiva topográfica. Vôos que, no percurso narrativo, peregrinam pelo Rio de Janeiro conduzindo-nos a lugares que marcaram a experiência na cidade do menino de rua e seqüestrador do ônibus, Sandro Nascimento. Agenciando as imagens de arquivo do seqüestro, captadas pelas câmeras de vigilância da CET/RJ (que controlam as ruas do RJ) e por diferentes emissoras de televisão que transmitiram o evento em tempo real, Padilha convoca os envolvidos na tragédia (jornalistas, policiais, reféns), os conhecidos e familiares de 
Sandro, bem como o ex-secretário de segurança do Rio de Janeiro, Luiz Eduardo Soares, para conferir um novo enfoque ao acontecimento e à relativização da culpabilidade de Sandro.

Interessante observar também que Rua de mão dupla, Edifício Master e Ônibus 174 integram uma constelação de imagens da/na cidade e remetem à vida em grandes centros onde foram filmados, endossando sua pertença urbana ao apresentarem fatura reflexiva do lugar da imagem como vigilância, controle e espetáculo nas cidades contemporâneas. Realizados em vídeo, no século XXI, incorporam às suas narrativas marcas de uma cultura mediada e controlada por dispositivos de captação de imagens. Nesse sentido, as paisagens impuras desses documentários remetem à impossibilidade de pensar o espaço urbano e a vida nas cidades sem a presença de imagens midiáticas, da diversidade de câmeras digitais, do olho atento das emissoras e das câmeras de controle em ambientes públicos e privados. É desde esse estado de impureza que Edifício Master, Ônibus 174 e Rua de mão dupla trazem ao centro da cena elementos de sua pertença urbana e engendram desde aí outras formas de narrar, reafirmando a arte cinematográfica sempre aberta a novos amalgamas e incorporações.

\subsection{A cidade digerida}

Mesmo os filmes de Cao Guimarães e de Eduardo Coutinho que em seus títulos reportam ao espaço público (uma rua e um edifício, respectivamente) e que desenvolvem suas narrativas no interior das casas, acabam por afirmar, a partir das 
ações e visões de mundo das personagens, o "espelhamento e referência constante à cidade como a matriz maior das experiências". ${ }^{24}$ Em uma perspectiva de inversão, poderíamos falar que a cidade imaginariamente engolida por seus habitantes, impregna as relações e manifesta-se através delas nos jogos e trocas (simbólicas) que se estabelecem entre documentarista e personagens no momento da filmagem. É nesse sentido que aderimos à percepção de Comolli em sua proposta de uma mudança da fórmula clássica do cinema dos "corpos nos cenários" para que possamos imaginar uma outra na qual os "cenários seriam levados nos corpos". A cidade aderindo ao "complexo de Jonas" 25 e sendo engolida por aqueles a quem deveria engolir. $\mathrm{O}$ engolidor sendo engolido, digerido e encarnado em um outro corpo que é, ao mesmo tempo, por ele habitado. ${ }^{26}$

A cidade, propõe Comolli, desaparece por dentro, torna-se "a mola, a armadura, o motor, a estrutura dos corpos". Não somente uma cidade que contamina seus habitantes e exterioriza-se nos seus relatos e movimentos, mas a cidade no interior dos habitantes.

A cidade encarnada, digerida pelos corpos dos seus, tornada pensamento no interior, na espessura, nas dobras da carne que toma forma no corpo (...) As coisas essenciais da cidade, de qualquer cidade $e$

24 XAVIER, Ismail. São Paulo no cinema: expansão da cidade máquina, corrosão da cidade arquipélago. Sinopse, v. VIII, n. 11, p.19, set. 2006.

${ }^{25}$ Cf. DURAND, Gilbert. As estruturas antropológicas do imaginário. São Paulo: Martins Fontes, 2002. p. 199-236. Durand desenvolve uma longa reflexão acerca dos símbolos de inversão como constituintes do regime noturno do imaginário. Segundo ele "Jonas é eufemização de todo o engolimento e, em seguida, antífrase do conteúdo simbólico do engolimento. Transfigura o despedaçamento da voracidade dentaria num suave e inofensivo sucking". p. 206.

${ }^{26}$ Idem. Ibidem. Grifo meu. 
seja qual for a experiência de cidade se inscreve no gesto do seu habitante, no corpo do "filho do lugar". 27

Um jogo de dupla inversão, tendo em vista que se a cidade está nos corpos ela também passa a possuir um corpo, em concomitância de metáfora e metonímia.

A parte pelo todo, mas ao mesmo tempo uma coisa pela outra: o corpo que vale por um cenário, mas, ao mesmo tempo, o cenário que se tornou corpo, um pedaço de cidade pela cidade. ${ }^{28}$

Nessa perspectiva simbólica, onde a cidade digerida atravessa a subjetividade e habita os corpos, os gestos e as expressões de seus habitantes, é que podemos pensar a "estética comportamental" 29 do encontro - que se estabelece com a câmera e por causa dela, gerando o acontecimento narrativo - entre o documentarista e suas personagens.

Sob o prisma dessa "digestão", gostaríamos de recolocar o pressuposto que orienta o percurso de nossa reflexão: nos documentários urbanos recentes a cidade se inscreve nos dispositivos de interação do documentarista com o outro. São os encontros (confrontos e desencontros) com esses outros somados ao resultado desse processo através da montagem, que se tornam os principais agenciadores na composição dessas cidades, ou mesmo de um espírito urbano. Como veremos em Rua de mão dupla, Edifício Master e Ônibus 174, a dramática das personagens, seus relatos e

\footnotetext{
27 COMOLLI, Jean-Louis. A cidade filmada. In: Cadernos de Antropologia e Imagem. v. 4: A cidade em imagens. Rio de Janeiro: UERj, 1997. p.165-166. Grifos meus. Cf. também o original: COMOLLI, JeanLouis. La ville filmée. In: ALTHABE, Gerard; COMOLLI, Jean-Louis (Orgs.). Regards sur la ville. Paris: Centre Georges Pompidou, 1984.

${ }^{28}$ Op. cit. p.166-167.

29 SIMMEL, G. Sociabilidade - um exemplo de sociologia pura ou formal. In: MORAES, E. (Org.). Sociologia: Simmel. São Paulo: Ática, 1983. p. 165-181.
} 
fabulações, suas referências a si próprios e aos outros expressas nas "artes" de fazer e dizer, ${ }^{30}$ bem como as performances realizadas para a câmera ou com ela (como é o caso das "personagens-câmera" de Rua de mão dupla ${ }^{31}$ ), atuam em um sentido de exterioridade, de compor e expressar a personalidade da cidade que se inscreve nas imagens documentais. Nesse sentido, mesmo apresentando estilos narrativos diversos - ou por causa deles -, possibilitam um cotejo entre seus dispositivos de interação propostos pelo documentarista com o pacto de adesão das pessoas envolvidas.

\subsection{O documentário como encontro e a inscrição da cidade na sociabilidade documental}

Nossa percepção, portanto, reafirma-se na crença de perceber o documentário como um encontro maquínico ${ }^{32}$, instaurador de dispositivos técnicos e conceituais. À dinâmica desses encontros entre documentarista e personagens e às formas de interação que ali se estabelecem, atribuímos o conceito de sociabilidade documental, inspirados nas teorias do ensaísta da metrópole Geor Simmel. O autor alemão, que desenvolveu suas teorias no nascer da modernidade européia, tornou-se conhecido como o sociólogo dos contrários, percebendo as reciprocidades e interações existentes entre conteúdo e forma. É na perspectiva simmelliana de

\footnotetext{
${ }^{30}$ DE CERTEAU, 1994. p. 83-86.

${ }^{31}$ Em Rua de mão dupla, como veremos adiante, são as personagens que portam as câmeras e realizam grande parte das imagens do documentário.

${ }_{32}$ Cf. expressão em DUBOIS, Phillippe. Vídeo, cine, Godard. Buenos Aires: Libros del Rojas..
} 
arranjos em espaços descontínuos, como são aqueles que regem a vida nas metrópoles, que se pode pensar a sociabilidade documental como um lugar narrativo onde o documentarista interage inscrevendo uma estética às relações, ao mesmo tempo em que vai sendo constituído por elas, num processo permanente.

Uma sociabilidade que, assim como o cinema, afirma-se como jogo e a arte do presente. Uma arte temporária e que estabelece formas no aqui e agora do seu acontecimento. Um jogo submetido a uma série de regras entre seus participantes, sem memória e tampouco vínculos com um antes ou depois. Em consonância com a arte e o jogo, a sociabilidade configura-se como uma expressão estética da interação entre os homens, uma forma lúdica de associação, onde o sentimento positivo - ou não - de pertencimento e do estar juntos faz com que atribuam valor a esta formação. O fenômeno urbano da sociabilidade, descola-se de seus conteúdos e desenha formas de "estar com um outro, para um outro, contra um outro". ${ }^{33}$ Fatos que a colocam em sintonia para pensar o momento da filmagem e os dispositivos de interação estabelecidos entre o realizador e as pessoas envolvidas. Como a noção de intercâmbio em Simmel, sublinho a idéia de dispositivo de interação como uma “ação recíproca" e de interdependência gerada a partir da proximidade," um processo de síntese espiritual que transforma a proximidade das coisas em uma relação de dependência mútua" ${ }^{34}$

Perspectiva que coloca a filmagem fundando uma realidade circunstancial, uma situação de partilha que ali se instaura com suas precariedades, tensões e conflitos entre sujeitos urbanos vulneráveis às diferenças e ao diferente. No jogo da

\footnotetext{
33 SIMMEL. 1983. p.168. Grifos meus.

${ }^{34}$ SIMMEL, Georg. Sobre la individualidad y las formas sociales. Quilmes: Universidade Nacional de Quilmes, 2002. p. 114. Grifos meus.
} 
alteridade a experiência diante do outro, como lembra Fickinger, 35 "dá-se antes de toda a atividade reflexionante", pois "trata-se sempre "de alguém que se encontra à nossa frente e, como tal, dirige-se a nós e inquieta-nos, devido única e exclusivamente ao fato de ser outro que nós mesmos." Diferenças que imprimem, nesses encontros, harmonias conflituais e dissonâncias.

Andréa França, refletindo acerca da “construção da imagem desejada de si (própria da situação de filmagem) e essa mesma imagem tornada filme, obra, fato estético (a partir da edição, montagem)", desenvolve a noção do documentário como “jogo sempre a ser jogado entre diretor e personagem". ${ }^{36}$ A situação de filmagem no documentário, percebe a autora "é uma circunstância em que todas as pessoas são sujeitos ao mesmo tempo em que estão sujeitas umas às outras e a uma situação determinada". ${ }^{37}$ Documentarista e personagem, sujeitos urbanos que partilham através de sua relação, com seus saberes e lugares, a construção de um conhecimento da cidade, inscrito no espaço narrativo.

Condição que relativiza as posições tradicionais de "sujeito" como aquele que conhece ou busca conhecer versus "objeto" como a realidade ou fenômeno a ser apreendido, colocando-os em um solo de pertença comum, sendo (co-)habitantes da cidade. Habitantes que, embora com estatutos diferenciados de poder e posição, situam-se no espaço urbano. "Nesse espaço comum, que é cotidianamente trilhado, (onde) vão sendo construídas coletivamente as fronteiras simbólicas que separam,

35 FLICKINGER, Hans Georg. Hermenêutica filosófica: nas trilhas de Hans Georg Gadamer. Porto Alegre: Editora da PUCRS, 2000. p. 27.

${ }^{36}$ FRANÇA, Andréa. Encenado papéis (ou o espaço do jogo em dois documentários). Revista Sinopse, São Paulo, USP, n. 11, set.2006. Nesse artigo a autora analisa a construção de "momentos de intimidade" em dois documentários recentes: Justiça (2004), de Maria Augusta Ramos, que se filia à tradição do filme observacional, camuflando a presença do realizador e Preto e branco (2003), de Carlos Nader, que expõe as negociações de filmagem.

${ }^{37}$ Op.cit. p. 53. 
aproximam, nivelam, hierarquizam ou, numa palavra, ordenam as categorias e os grupos sociais em suas mútuas relações". 38 Fronteiras flexibilizadas no encontro documental a ponto de estabelecer "zonas de contato e negociação"; 39 zonas onde se compõem as relações narrativas.

Portanto, o que aqui estamos pensando como sociabilidade documental urbana traduz-se nas formas que adquirem esse encontro entre o documentarista e suas personagens e que estabelecem um jogo de reciprocidades sempre frágil, precário e inter-relacional, expresso em maneiras diversas de interação. Jogo no qual “tanto quem filma como quem é filmado tem papéis bastante ativos, assim como provisórios e cambiáveis a depender da própria situação de negociação dos indivíduos na filmagem" ${ }^{40}$ Situações que ocorrem com a presença da câmera e por causa dela, fato que cola a sociabilidade documental ao acontecimento narrativo, inscrevendo-a como "o lugar onde esse acontecimento fílmico é chamado a se produzir" $^{41}$

No nosso entender, foi no nascer do documentário moderno que se instituíram, graças aos dispositivos técnicos, aliados a preceitos estéticos e conceituais, formas diferenciadas de partilha, de encontro e do estar com o outro no espaço narrativo. Instaurando um jogo de proximidades e distâncias, Crônica de um verão e Primárias, filmes manifestos do cinema verdade e do cinema direto,

\footnotetext{
38 ARANTES apud LEITE, R. P. Contra-usos e espaço público: notas sobre a construção social dos lugares na Manguetown. Revista Brasileira de Ciências Sociais. São Paulo, ANPOCS/Edusc, v. 17, n. 49, p. 130. jul. 2002.

${ }^{39}$ Idem. Ibidem.

${ }^{40}$ Op.cit. p. 52.

${ }^{41}$ PARENTE, André. Narrativa e modernidade. Campinas: Papirus, 2000. p. 121. O autor parafraseia a concepção de narrativa de Maurice Blanchot, pois, segundo ele, é assim que percebe tanto o cinema direto como os filmes não-narrativos.
} 
respectivamente, configuraram formas de sociabilidade documental que desdobram suas influências ainda contemporaneamente. É o que veremos no capítulo a seguir. 


\section{PROXIMIDADES E DISTÂNCIAS NA CONSTRUÇÃO DAS CIDADES DOCUMENTAIS}

O espírito produz inumeráveis formas que perduram com uma autonomia especialíssima, independentes da alma que as cria e de outra alma qualquer que as aceita ou rechaça.

Simmel

Partindo da perspectiva, já anunciada anteriormente, da sociabilidade documental como acontecimento narrativo configurador de encontros, confrontos e “embates cineasta mundo"1, gostaríamos de resgatar alguns elementos estéticoconceituais das tradições do cinema direto norte-americano e do cinema verdade através dos filmes Primárias (Primary, 1960, Estados Unidos, Robert Drew e Richard Leacock) e Crônica de um verão (Chronique d'un été, 1961, França, Jean Rouch e Edgard Morin). Sugerimos que eles instituíram, a partir de seus estilos, diferentes

\footnotetext{
${ }^{1}$ Expressão de XAVIER, Ismail. O cinema brasileiro dos anos 90. Estudos marxistas 9. São Paulo: Hucitec,
} 2000. p. 122. 
modulações de proximidade e partilha urbanas até então inéditas e ainda atualizadas, de maneira impura e híbrida, nos documentários contemporâneos.

Por um lado, como veremos, Crônica de um verão opera em horizonte reflexivo no qual os documentaristas tornam-se personagens, atuando diante da câmera. $\mathrm{O}$ processo do filme é desde o início revelado e debatido tornando-se o próprio filme o acontecimento narrativo. Aqui as noções de proximidade e partilha são constituídas a partir da presença-imagem dos realizadores, na divisão e inter-relação no espaço filmico com os outros participantes da experiência. No seu método de filmagem desenvolve-se toda uma dramaturgia da intervenção documental através de um amplo repertório de possibilidades (enquetes de rua, entrevistas, conversas íntimas, debates, espectadores integrados ao filme, etc). A palavra emerge como elemento central no jogo da sociabilidade e rege os encontros entre as personagens. Da intenção dos realizadores em relação ao filme, aos sentimentos, opiniões e memórias dos entrevistados, tudo passa pela fala e a palavra torna-se, assim, veículo de integração e confronto, engendrando o espaço narrativo como um lugar de evocação do imaginário e da fabulação regidos pela oralidade.

Primárias opera em registro mais distanciado e funda um estilo no qual a transparência entre o material documentado e o espectador é preservada em nome do efeito de real desejado por Robert Drew e sua equipe. Ao contrário do cinemaverdade, que promove o encontro cênico entre documentaristas e documentados, o cinema direto evita o contato direto com as personagens desenvolvendo uma filosofia da não-intervenção em relação ao universo abordado. A preocupação central é propor uma narrativa onde os gestos, ações e falas das personagens se bastem para 
contar a história, sem a necessidade de perguntas do diretor ou da narração over (reduzida a poucos minutos no total da obra).

Porém, se em Crônica de um Verão o documentarista passa à frente da câmera, aqui ele se configura como o sujeito da tomada e, mesmo sem entrar em quadro, articula na relação câmera-personagens uma outra noção de proximidade e partilha. O corpo do realizador não se oferece como imagem, característica da tradição francesa, mas configura-se como uma presença que observa a um só tempo de perto e de forma distanciada as experiências das pessoas documentadas. A proximidade, portanto, desenha-se pelo ponto de vista do documentarista-câmera que afirma a singularidade do seu olhar na estética de captação das imagens. Os detalhes da ação passam a ser importantes para o atento observador, que silencioso e sem jamais se revelar em cena conduz o espectador a compartilhar o nascimento de toda uma dramaturgia dos gestos e de uma pedagogia do "observar próximo para observar bem" - a movimentação que se desenrola diante do documentarista e da câmera. Podemos até mesmo propor que a tradição norte-americana engendra o espaço narrativo como um lugar da fabulação regida pela ação e gestualidade das personagens em inter-relação com o gesto cinematográfico do documentarista.

Apesar de estabelecerem métodos e estéticas diferenciadas entre si, o verdade e o observacional, em suas origens, tinham em comum a convenção de alguns dogmas como a ausência de roteiro, a captação das imagens e das situações no seu acontecer, câmera na mão, equipe reduzida, trabalhar com não atores, ou seja, com pessoas comuns, e, sempre que possível, com iluminação natural. Renovações estilísticas que se deram, em parte, graças às mudanças técnicas, conceituais e 
estéticas potencializadas por uma época que propôs uma vigorosa mudança de valores sociais e, consequentemente, da paisagem do mundo urbano contemporâneo. As câmeras 16mm (blimpadas) e o som sincrônico à captação de imagem possibilitaram, além da redução da equipe e de uma maior mobilidade da câmera, novas formas de encontro e inter-relação do realizador com o universo documentado.

Percebemos, assim, que no nascer do documentário moderno configura-se, dentro de um mesmo tempo histórico e possibilidades técnicas comuns, um campo documental $^{2}$ riquíssimo aonde o estilo narrativo do cinema verdade viria a problematizar o do cinema direto norte-americano criando, mesmo que indiretamente, um território de disputas e de questionamentos acerca das propostas éticas e estéticas de cada um. Ressaltaríamos, sobretudo, a visibilidade e intervenção do cinema-verdade - em simetria oposta à proposta de não-intervenção e invisibilidade dos realizadores do cinema direto norte-americano - que, em política reflexiva, acabavam por tensionar os dogmas da pura observação. Os franceses pareciam gritar aos olhos e ouvidos dos norte-americanos que para haver encontro é preciso uma série de pactos, acordos e negociações com os filmados e, mais do que isso, eles devem ser revelados, trazidos ao interior da cena, transformados em acontecimento e em encenação.

Tanto os corpos daqueles que tradicionalmente ocupavam o extracampo, como também os dispositivos cinematográficos, afirmava indiretamente o cinema-verdade ao

\footnotetext{
2 Remetemos aqui à noção de "campo intelectual" desenvolvida por Pierre Bourdieu, ao longo de sua obra, para perceber o campo documental como um lugar de disputas e tensões de representação e legitimidade narrativa, bem como uma adesão às regras estilísticas e sensação de pertencimento e filiação à determinada tradição. Cf. BOURDIEU, Pierre. Esboço de auto-análise. São Paulo: Companhia das Letras, 2005 e A ontologia política de Martin Heidegger. Campinas: Papirus, 1989.
} 
seu contemporâneo observacional que tudo ocultava (na ambição de melhor revelar), estão presentes no momento da filmagem, alteram a realidade registrada e, portanto, devem ser transmutados em imagem, ofertados à precariedade da representação cinematográfica. Assim, são nesses dissensos narrativos do advento do cinema direto dos anos 60, que ocorrem no interior do campo documental, que devemos entender a diversidade dessas propostas de sociabilidade documental urbana com suas modulações de proximidades e distâncias (cênicas).

\subsection{A inscrição do tempo urbano no espaço narrativo}

François Niney constata que essas tradições do direto, em suas atualizações e dramáticas, recolocam em causa a noção de acontecimento que se reformula diante das novas práticas documentais preocupadas com o registro das miudezas e cotidianidades. O acontecimento, diz o autor, "passa a ser não mais o sensacional, mas a vida ordinária; não mais o teatral, mas o espontâneo, não mais a história regida por um roteiro, mas aquela que se apresenta (e se presentifica) diante da câmera" 3 .

Os documentários até os anos 50 eram, em sua maioria, dominados pelos pressupostos clássicos e com fins didáticos herdados da escola inglesa dos anos 30 . John Grierson, fundador dessa linhagem, estudioso e militante das causas sociais, desenvolveu um modelo de documentário que expressava suas ambições

\footnotetext{
${ }^{3}$ NINEY, François. L'épreuve du réel à l'écran: essai sur lê príncipe de la réalité documentaire. Bruxelles: De Boeck\&Larcier s.a., 2002. p.131.
} 
pedagógicas em relação às artes cinematográficas. Já em 1929, dirige seu primeiro e único filme, Drifters, que estabeleceria parâmetros de realização e que dominaria a cena documental por longo tempo. São filmes de propaganda e engajamento onde a preocupação com o lugar do homem no processo de desenvolvimento industrial centraliza o foco do pai do documentarismo inglês. Influenciado, não sem críticas, por Flaherty, que o inspirou a partir de Moana, 1926, a definir o documentário como tratamento criativo da realidade, bem como por Vertov, em sua poética do cotidiano. Em 1939 Grierson é convidado a coordenar a equipe do ONF (Office National du Film Canadien), estendendo ainda mais a influência de seus conceitos documentais.

Apesar da dinâmica do modelo fundado por Grierson, que se acrescia de novos elementos implantados pelos membros da EMB Films Unit ${ }^{4}$, havia um repertório estilístico, mais ou menos estabelecido, do qual faziam parte encenações com atores, trilhas, montagem analítica e, sua marca mais constante, a autoridade narrativa, com fins didáticos, professada em voz over (voz de Deus), explicando e reduzindo as possibilidades de leitura da imagem.

No contrafluxo da tradição clássica, é nessa década de 50 que há todo um movimento na França, nos Estados Unidos, na Inglaterra e no Canadá de “aspirantes a um cinema mais verdadeiro" 5 que recusam as encenações, partindo em busca de formalizar uma linguagem que dê conta de captar a vida como ela se apresenta, no momento de seu acontecer, com as pessoas que verdadeiramente vivem as situações

\footnotetext{
4 A Empire Marketing Board Films Unit contava com uma equipe em que, entre os nomes mais importantes, figuravam Paul Rotha, Basil Wright, John Taylor, Alberto Cavalcanti e Flaherty que, convidado por Grierson, foi contratado temporariamente para realizar Industrial Britain, 1931.

5 Op.cit., p.133.
} 
e não mais com atores representando papéis. Inaugura-se ali um novo pacto entre personagens reais, documentarista e câmera.

Os precursores do fim dos anos 50 - Free cinema britânico, Candid eye canadense, cinema direto quebequense e norte-americano, Nouvelle Vague e cinema-verdade francês - se acordam todos a procurar uma liberdade de filmar, uma vivacidade da tomada realizando-a sobre a vida que havia sobre os seus olhos'.

É, de certa forma, a retomada da mobilidade da câmera e inventividade do ponto de vista nascida e valorada pelas sinfonias metropolitanas, como percebe Aumont que propõe pensar os anos 20 na Alemanha, França, Rússia e Estados Unidos como “a época do reino das câmeras, cujas qualidades são, em toda parte, consideradas, realçadas, salientadas". A inventividade visual ao adotar um ponto de vista inédito e a mobilidade fazem parte do repertório experimental e seriam, segundo ele, um território comum às chamadas sinfonias metropolitanas de Routman, na Alemanha (Berlim, sinfonia de uma metrópole, 1929), Vertov na URSS (Um homem com a câmera, 1926) e Vigo, na França (À propos de Nice, 1930). “Os cineastas constroem aí retratos imaginários de cidades, no modo de fragmentação infinita, retalhados, em resposta mais ou menos consciente, ao sentimento difuso de uma ordem urbanística ainda em gestação, fundada sobre a circulação e a descentralização" 7 .

Nesse sentido de atualizar a tradição vanguardista, merecem destaque as produções do Nacional Film Board do Canadá e, sobretudo, Aiguiller de tram, 1954, de Roman Kroitor, um curta-metragem que segue a movimentação de um imigrante

\footnotetext{
${ }^{6}$ Idem, ibidem.

7 AUMONT, Jaques. O olho interminável: cinema e pintura. São Paulo, Cosac\&Naify, 2004, p. 69.
} 
polonês encarregado de limpar os trilhos por onde passam os trens do nascer do dia até à noite. Filme que antecipa, segundo $\mathrm{Niney}^{8}$, não somente uma câmera que acompanha os passos da personagem, como também lhe confia a narração off realizando "uma espécie de documento autobiográfico onde a subjetividade da voz disputa à objetividade da imagem" ${ }^{\prime \prime}$ antecipando, dessa maneira, o recurso narrativo que Rouch utilizaria em Eu, um negro, 1958.

Também dessa década Bientôt Noël (The days before Christmas), 1958, é um filme relevante, pois reúne à câmera Michel Brault (que iria posteriormente à Paris filmar Crônica de um verão) e Macartney-Filgate (que comporia uma das equipes de Primárias), além de Georges Dufaux e Wolf Koening. Produzido pela mesma Nacional Film Board do Canadá, Bientôt Noël foi um dos primeiros documentários a usar o som sincrônico captando os ruídos ambientes do espaço urbano, além das conversas das crianças com o Papai Noel. Além disso, há um travelling clássico, citado por Marsollais, Rouch e Niney ${ }^{10}$, que parte do cofre do banco que se fecha para seguir a pistola de um policial que acompanha o dinheiro até sua chegada no carro blindado onde ele é guardado. Plano emblemático de uma época que buscava formas de narrar que seriam consolidadas no cinema direto e também libertar a câmera do tripé.

Inventividade do ponto de vista e mobilidade da câmera que o neo-realismo reelabora, sobretudo nos filmes de Rossellini, ensaiava inscrever no gesto cinematográfico a paisagem das relações humanas conjugada a um sentimento de

\footnotetext{
${ }^{8}$ Op.cit., p.136.

${ }^{9}$ Idem, ibidem.

${ }^{10}$ Cf. MARSOLAIS, Gilles. L'Aventure du cinéma direct. Paris: Seghers, 1973. p.116. ROUCH, Jean. La caméra et les hommes. In: FRANCE, Claudine (org.). Pour une Anthropologie Visuelle. Paris: Cahiers de l'homme, 1978. p. 62. NINEY, op.cit., p. 136-137.
} 
estar no mundo, bem como à própria expressão desse mundo urbano desencantado do pós-guerra. A linguagem cinematográfica era capaz de avançar nessa direção como demonstram os pressupostos estéticos do diretor italiano preconizando as rupturas das tradições documentais modernas. Estéticas apoiadas, principalmente, no princípio da personagem e de seus movimentos que fazem com que o diretor desenvolva toda uma filosofia da espera e da revelação (do espaço).

Eu procedo de maneira exatamente oposta (à decupagem clássica): um homem se desloca e a favor de seu deslocamento descobrimos o meio em que ele se encontra. Eu começo sempre com um primeiro plano, depois o movimento do aparelho que acompanha o ator descobre o ambiente. Trata-se então de não abandonar o ator e este de efetuar os trajetos completos ${ }^{11}$.

Neste itinerário estético proposto por Rossellini, de descortinar o espaço pela personagem e de acompanhá-la em sua trajetória, há uma premonição, por assim dizer, do estilo que marca o nascimento da primeira idade do cinema direto. Ou seja, a sensação do espaço transformado em tempo, onde o tempo é movimento e este serve para medir a duração e descortinar o espaço. Esta marcação do tempo pelo movimento, tão característica dessa etapa do direto, esta espera pelos movimentos da personagem imprimem, na visibilidade dos gestos ordinários, densidade temporal à narrativa. A câmera se desloca, adere ao ritmo da caminhada, ela é o sujeito urbano que a um só tempo observa e vivencia o evento, submersa na situação. Isto imprime um outro tempo narrativo, uma certa banalidade na duração, no tempo que passa e

${ }_{11}$ BERGALA, Alan. Roberto Rossellini. Le cinéma révélé. Paris: Cahiers du cinéma, 1984. p. 41. Tradução e grifos meus. 
no estar ali, nesta presença do tempo que passa junto às personagens. Uma câmera que peregrina nas ruas e nos acontecimentos fazendo com que a paisagem urbana adquira densidade na contextualização e produção de sentidos.

Mas aqui também, apesar das condições técnicas muito similares, a mobilidade e inventividade das tradições do direto e verdade são contaminadas por seus preceitos estético-conceituais distintos. Enquanto o direto norte-americano tem como princípio observar a personagem na situação vivenciada e entrar em sintonia com a cadência de seus movimentos assumindo, muitas vezes, uma câmera subjetiva indireta na aderência de seus pontos de vista - Primárias, Don't look back, 1966, e The Beatles: The First US Visit ,1964 são exemplares nesse sentido - o cinema-verdade de Rouch aposta a relação entre "a câmera e os homens"12 em um "cine-diálogo" onde a interação com os fenômenos registrados contamine o documentarista e o leve a um estado de possessão, de "cine-transe", como nominava o antropólogo.

Para mim a única maneira de filmar é de caminhar com a câmera, de conduzi-la onde ela é mais eficaz e de improvisar para ela um outro tipo de ballet onde a câmera torne-se tão viva quanto os homens que ela filma. Está aí a primeira síntese entre as teorias vertovianas do "cine-olho" e a experiência da "câmera-participante" de Flaherty. Esta improvisação dinâmica - que eu comparo à improvisação do toureiro diante do touro - onde nada é dado antecipadamente e a suavidade de uma faëna não é outra coisa que a harmonia de um travelling com a câmera na mão em perfeita adequação com os movimentos dos homens filmados ${ }^{13}$.

${ }^{12}$ Referência ao artigo de Rouch que mencionamos aqui. Cf. Op.cit.

${ }^{13}$ Idem, ibidem. 
$\mathrm{Na}$ "adequação com os movimentos dos homens" e do mundo traduzidas em formas sensíveis e expressivas, as antropólogas Eckert e Rocha ${ }^{14}$, em reflexão acerca dos desafios de filmar a/na cidade, propõem que a evolução da linguagem cinematográfica revela a maneira dos cineastas apreenderem e reformularem criativamente as pulsações dos tempos urbanos, bem como de comunicá-los dramaticamente através das estéticas cinematográficas. Nesse sentido, propomos que Crônicas de um verão e Primárias inscrevem o espírito urbano de seu tempo comunicando-o através de formas narrativas. Suas propostas estilísticas, que já vinham sendo germinadas em trabalhos e movimentos cinematográficos anteriores, consolidam-se, no nascer dos anos 60, e formalizam, cada uma a seu modo, tradições documentais que se unem com maestria ao ritmo, ao movimento, aos gestos, à duração e às ondulações da dinâmica urbana contemporânea e de seus personagens.

Vejamos o contexto onde elas nascem para propormos que, na gênese das tradições do documentário, modernas são configuradas, a partir do encontro entre os realizadores e as personagens, estéticas do distanciamento e da intimidade, caras à sociabilidade documental.

2.2. Prévias de Primárias: o encontro de Robert Drew, Richard Leacock, D.A. Pennebaker e Albert Maysles

14 ECKERT, Cornélia; ROCHA, Ana Luíza. Les enjeux du temps moderne: ville et cinéma. In: Filmer la ville. Premières rencontres anthropo-cinématographiques de Besançon UFR Lettres et Sciences Humaines, Section d'Anthropologie et de Sociologie. France: Besançon, 2002. 
A trajetória que leva à realização de Primárias demonstra que ali houve a consagração de uma profunda pesquisa iniciada pelo jornalista norte-americano Robert Drew, que ambicionava construir um outro modelo de reportagem televisiva. Buscando na própria linguagem televisual e no estudo da dramaturgia as inspirações para esse empreendimento, encontraria ao longo do percurso companheiros que o ajudariam a concretizar suas ambições. Assim, Primárias é o resultado de alguns anos de pesquisas, iniciadas por Drew e aprimoradas junto aos seus parceiros ${ }^{15}$, em que desenvolveram uma nova dramaturgia documental centrada na ação das personagens e no princípio da não-intervenção.

Era o primeiro filme em que conseguíamos que a câmera com som sincronizado se movimentasse com os personagens seguindo a história (...). Éramos como uma pessoa, podíamos nos mexer e tomar decisões enquanto nos movíamos. E foi isso que tornou Primary um divisor de águas: o fato de podermos filmar o que estava acontecendo no momento, sem nenhuma direção ou imposição de nossa parte ${ }^{16}$.

Já há algum tempo Drew empenhava-se em construir um novo paradigma na maneira de fazer televisão, mais liberta da herança radiofônica. Jornalista da revista Life, como lembra João Salles, “convivia diariamente com as fotos de Capa, CartierBresson, Eisenstadt, McAvoy que lhe davam a sensação de acesso direto aos fatos. Era como estar junto da ação, sem mediações"17. Suas primeiras tentativas de

\footnotetext{
${ }^{15}$ Richard Leacock, DA Pennebaker, Albert Maysles , Terrence McCartney Filgate, Bill Knoll.

${ }^{16}$ Depoimento de Robert Drew nos Extras do DVD Primárias (Primary), Rio de Janeiro, Videofilmes, 2006. Todas as falas de Drew e Leacock, daqui em diante, serão retiradas desta fonte.

17 SALLES, João Moreira. Sobre senadores que dormem. (texto publicado originalmente na revista Bravo, n. 85, abril de 2005). Encarte do DVD Primárias (Primary), Rio de Janeiro, Videofilmes, 2006.
} 
importar o espírito das fotos às imagens em movimento não foram bem sucedidas, pois acabaram reproduzindo um modelo de televisão que abominava, mas ainda sem precisar muito o porquê.

O que descobri é que a reportagem na televisão e a reportagem que eu fazia estavam baseadas na lógica da palavra. (...) A vida real nunca aparecia no filme, nunca aparecia no aparelho de televisão. Teríamos que abandonar a lógica da palavra e encontrar uma lógica dramática em que as coisas realmente acontecessem. Se fizéssemos isso obteríamos uma concepção totalmente nova, de um jornalismo totalmente novo. (...) Seria como um teatro sem atores, peças sem autores, seria reportagem sem editorial e opinião. Seria a capacidade de ver a vida das pessoas em momentos cruciais em que poderíamos deduzir algumas coisas, e ver um tipo de verdade que só pode ser obtido através da experiência pessoal ${ }^{18}$.

Ou seja, desde sempre Drew ambicionou a fabricação de um efeito de verdade instrumentalizando-se com os artifícios possíveis da ficção. Isso o motivou a tirar licença da revista e ir a Havard estudar jornalismo para tentar entender essa lógica da palavra e superá-la com a construção de uma nova forma dramática: "tentei idealizar um plano para um novo jornalismo que usasse câmeras que se movimentassem livremente com pessoas", condição fundamental para a ruptura estilística que ambicionava. O equipamento pesadíssimo e a dificuldade de captar o som ao mesmo tempo em que a imagem eram fatores que dominavam a cena

\footnotetext{
${ }^{18}$ Extras do DVD Primárias (Primary), Rio de Janeiro, Videofilmes, 2006. Grifo nosso.
} 
televisiva e cinematográfica favorecendo o predomínio da herança radiofônica e da tradição griersoniana, explicando as imagens a partir de uma narração over ${ }^{19}$.

Aliás, Grierson é uma referência citada por Drew ${ }^{20}$ em sua ambição de provocar uma partilha do conhecimento do mundo e dos seus problemas através da imagem cinematográfica. Diz ele:

Grierson acreditava que a democracia funciona na experiência comum compartilhada e temos que conquistar essa experiência. E a forma de fazer isso é construir um teatro cinema em cada povoado e realizar filmes documentários com suficiente visão do mundo. E, uma vez por semana, todos os membros de uma nação irão ao pequeno teatro no seu próprio povoado e assistirão esses filmes e assim receberão educação. Eu não concordo inteiramente com Grierson porque ele se vê como um professor e um divulgador além de ditar o que seria melhor pra você. Mas suas idéias sobre um teatro-cinema em cada povoado coincidiram com o desenvolvimento do cinema-verité e o desenvolvimento da televisão. E temos um teatro na sala de cada casa.

Para além das intenções de partilha de Grierson, a estética do documentarismo clássico, tal como a concebeu nos anos 30, com encenações, narrações oniscientes em voz impostada e textos professorais estava fadada a caducar em um didatismo enfadonho. Contudo, para superá-la era preciso novas

${ }_{19}$ Voz over ou voice over: narração sobreposta à imagem. Quando a voz se descola da imagem em espaço e tempo.

20 Extras do DVD Primárias (Primary), Rio de Janeiro, Videofilmes, 2006. 
estratégias narrativas e, sobretudo, equipamentos que permitissem uma consonância entre as mobilidades da imaginação e as da filmagem²1.

Adriana Cursino lembra que

Drew levou aproximadamente seis anos para desenvolver o equipamento necessário: câmera portátil com cristal para sincronização, gravadores que substituíram as válvulas pelos transistores e por isso ficam mais leves, oferecendo a possibilidade de sincronizar som e imagem in loco, console de edição portátil com várias pistas de som que pudesse ser montado em qualquer quarto de hotel, permitindo edição imediata do material ${ }^{22}$.

O encontro com Leacock foi fundamental na implementação dessas mudanças e os esforços de Drew começam a fazer sentido. Posteriormente, juntaram-se a eles DA Pennebaker e Albert Maysles e Macartney-Filgate, um dos integrantes do movimento Candid Eye, precursor do estilo direto no Canadá. Maysles, junto com seu irmão David, Pennebaker e Leacock ${ }^{23}$ tornar-se-iam, independentemente de Drew, mas aprimorando os preceitos esboçados por ele, nomes fundamentais do cinema observacional. Um dado curioso é que Leacock havia trabalhado com Robert Flaherty como câmera-man em Louisiana Story, 1948, mas é através de um filme exibido no programa de televisão Omnibus, da NBC, que Drew, impactado pela narrativa visual, chega até Leacock, responsável pela direção de fotografia da reportagem.

\footnotetext{
${ }^{21}$ André Parente, em suas aproximações do campo do direto, fará uma distinção radical entre a tradição norte-americana a qual considera "ligada ao sistema de representação clássica" e aquelas adotadas por Rouch, Perrault e Cassavetes que nominará como cinema indireto, vinculados ao cinema moderno.

22 CURSINO, Cinema diriana. norte-americano. http://www.pos.eco.ufrj.br/revista/modules/wfsection/print.php?articleid=94

${ }^{23}$ Leacock formaria um grupo denominado Living Câmera.
} 
A trupe chegava na cidade e armava a lona do picadeiro e, à medida que a lona era armada você tinha uma noção do tamanho da tenda, do seu volume etc. Em seguida a tenda se enchia de pessoas de forma que, em última análise, você se sentia dentro da tenda cercado de pessoas e essa sensação advinha do filme e não da narração. Um cara chamado Leacock constava nos créditos como fotógrafo. Eu fui atrás dele e o encontrei no porão, no centro da cidade, no escuro, sentado em uma moviola editando um filme. Eu entrei, ele mal me deu atenção e perguntei por que o filme era tão bom e ele disse: Porque Russel Lyons escreveu uma ótima narração. Aí pensei com meus botões 'muito bem, talvez seja ele o cara que fez o filme’24.

E Drew chama Leacock para trabalhar com ele.

\subsection{Primárias: a cidade observada e a sociabilidade distanciada}

Com o equipamento quase pronto, Drew parte em busca de uma história:

(...) o que aconteceu foi que a câmera sincronizada de som portátil só ficaria pronta em uma determinada época. Acho que foi em abril de 1960. Então, tive que procurar uma história para poder filmar nossa primeira experiência. E o jovem senador estava concorrendo à Presidência em Wisconsin e ele me agradava muito por estar enfrentando um desafio quase impossível contra a máquina democrática.

${ }^{24}$ Extras do DVD Primárias (Primary), Rio de Janeiro, Videofilmes, 2006. 
Drew e Leacock vão à Detroit conversar com Kennedy sobre o filme e propõem acompanhá-lo durante os cinco dias e noites, filmando tudo o que estava acontecendo e que ele, Kennedy, não deveria se incomodar com a presença das equipes. "Pra coisa funcionar ele deveria confiar na gente". Drew fez essa mesma proposta a Humphrey que, ao contrário de Kennedy, não hesitou em aceitá-la.

Assim, Primárias colocou em prática uma série de princípios que vinham sendo desenvolvidos durante esses anos de pesquisas criadas por Drew em busca de um telejornalismo diferente e que foram aprimoradas, em ato, pelas equipes que participaram do filme com as recomendações do diretor: "sem entrevistas, não pedir às pessoas fazerem coisas, nunca pedir pra ninguém repetir coisa alguma e manter-se transparente"25. Dogmas que acabam por compor a figura do cineasta, ambiguamente, como uma presença-ausente, partilhando situações públicas e momentos de intimidade com suas personagens, mas de maneira silenciosa e sem jamais se colocar em cena. Composições que seriam aprimoradas e relidas, posteriormente, em obras primorosas das quais destacaria Don't look back, de Pennebaker, The first visit the Beatles in the USA, Gimme shelter,1970, Salesman, $1968 e$ Grey gardens, 1975, dos irmãos Maysles que, nesse último filme, rompem com os dogmas de transparência do observacional demonstrando vários momentos de cumplicidade, entrosamento e até mesmo confronto com as personagens.

Nesse filme, os irmãos Maysles acompanham o cotidiano de Edith Bouvier Beale, uma senhora de 79 anos, e de sua filha Edie, com 57. Elas moram em Grey Gardens, uma mansão em estado de deterioração e por isso se vêem ameaçadas de despejo pelas autoridades locais. O clima entre as duas é hostil e ao longo do período ${ }^{25}$ Comentário de Leacock e Drew ao filme Primárias. Extras, DVD Primárias. 
de filmagens elas conversam com os realizadores que respondem, fazem algumas perguntas e observam. Estimuladas pela presença dos documentaristas as memórias de Grey Gardens atravessam as histórias de vida das personagens. Edie é constantemente agressiva e podemos perceber que Albert, à câmera, começa a tomar partido da velha senhora desencadeando uma atitude mais violenta da filha que o insulta verbalmente. Relação que rompe com os dogmas até então perseguidos pelos documentaristas que mantinham-se, até ali, fieis e aprimorando os preceitos propostos por Drew.

Primárias é também um filme que experimenta e inventa estilisticamente. A célebre caminhada em que Leacock segue a entrada em cena de J.F.Kennedy na sociedade polonesa, carregando a câmera acima da cabeça, sem poder visualizar o que registrava, em um longo plano seqüência, testando uma lente grande-angular que

Pennebaker foi, segundo Rouch"26,"o carro-chefe desse novo estilo de filmagem". Estética de

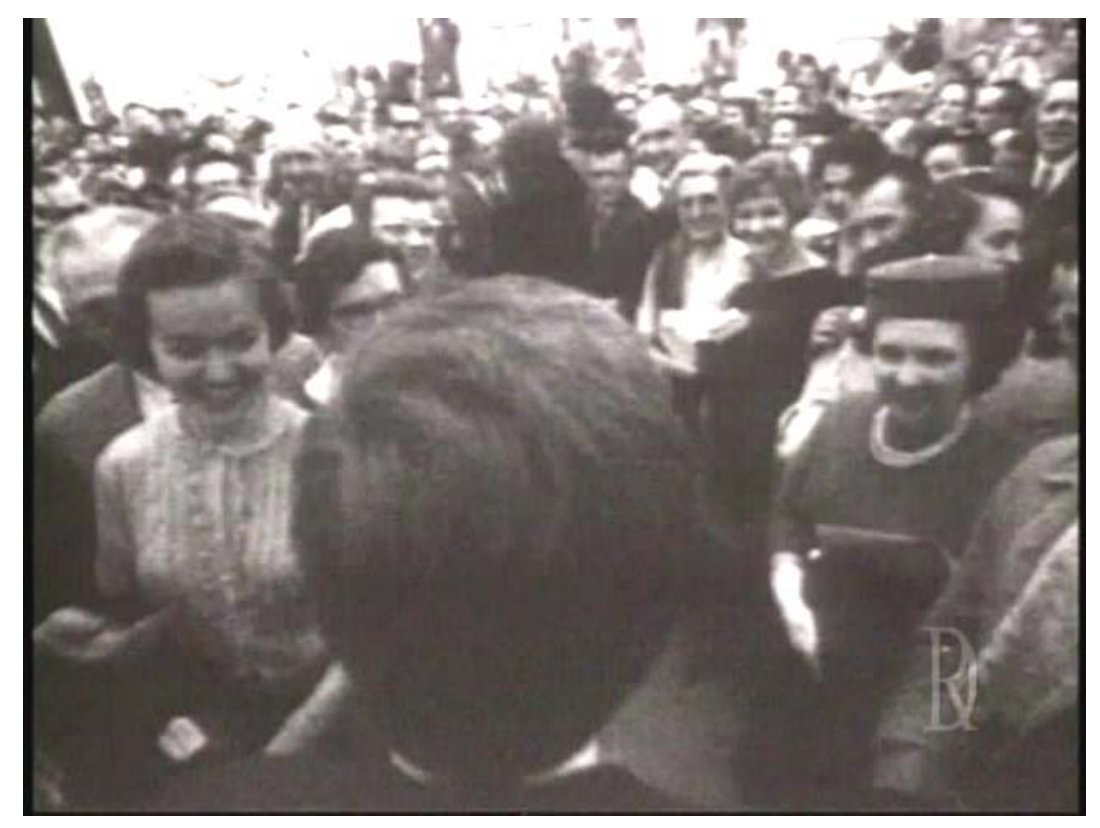
captação que viria a contaminar nas cenas cinematográficas e televisuais dali em diante, "seguir uma pessoa em som sincronizado hoje em dia pode parecer banal. Mas, em 1960, era uma total raridade" como diria Drew.

${ }^{26} \mathrm{ROUCH}$, Jean. op.cit., p.62. 
Talvez contagiado pelos princípios jornalísticos da imparcialidade, Primárias apresenta momentos emblemáticos na composição de uma "sociabilidade documental distanciada". Um deles são os depoimentos que integram o momento da votação construído em montagem paralela alternando o interior da sala com cenas externas, o ambiente da rua. Na primeira seqüência Kennedy está à porta de uma zona eleitoral cumprimentando os eleitores que entram. Corta para o interior do local de votação, com depoimentos em off falando em qual candidato votariam e o porquê. Depoimentos que têm sua duração até a última imagem de um eleitor entrando na cabine de votação. Corta para a seqüência seguinte que identifica de onde vêm essas vozes. São depoimentos de eleitores que estão de perfil para a câmera, recortados em close, com o movimento da cidade desfocada ao fundo, conversando com alguém que está fora de quadro e de quem não ouvimos a voz.

Hoje em dia diríamos que é uma enquete, embora ainda não houvesse esse conceito à época, com pessoas na rua dando seus palpites sobre o resultado das eleições. Inaugura-se ali uma estética comum ao telejornalismo e mesmo a estilos de documentários que adotam depoimentos de anônimos como método narrativo. Uma conversa onde o entrevistador guarda distância do entrevistado não revelando ao espectador suas perguntas, sua voz ou figura. O sentido se constrói a partir das próprias respostas daqueles que estão sendo inquiridos. Depoimentos que guardam a alma dos dogmas do cinema observacional da presença ausente do documentarista através da não-intervenção. ( $\mathrm{O}$ caráter de distanciamento desses depoimentos acentua-se, sobretudo, em contraponto à moda do cinema-verdade, onde veremos Marceline e Nadine em quadro, microfone em punho, Nagra a tiracolo em, 
literalmente, um corpo a corpo com seus entrevistados na busca de saber se eles são felizes).
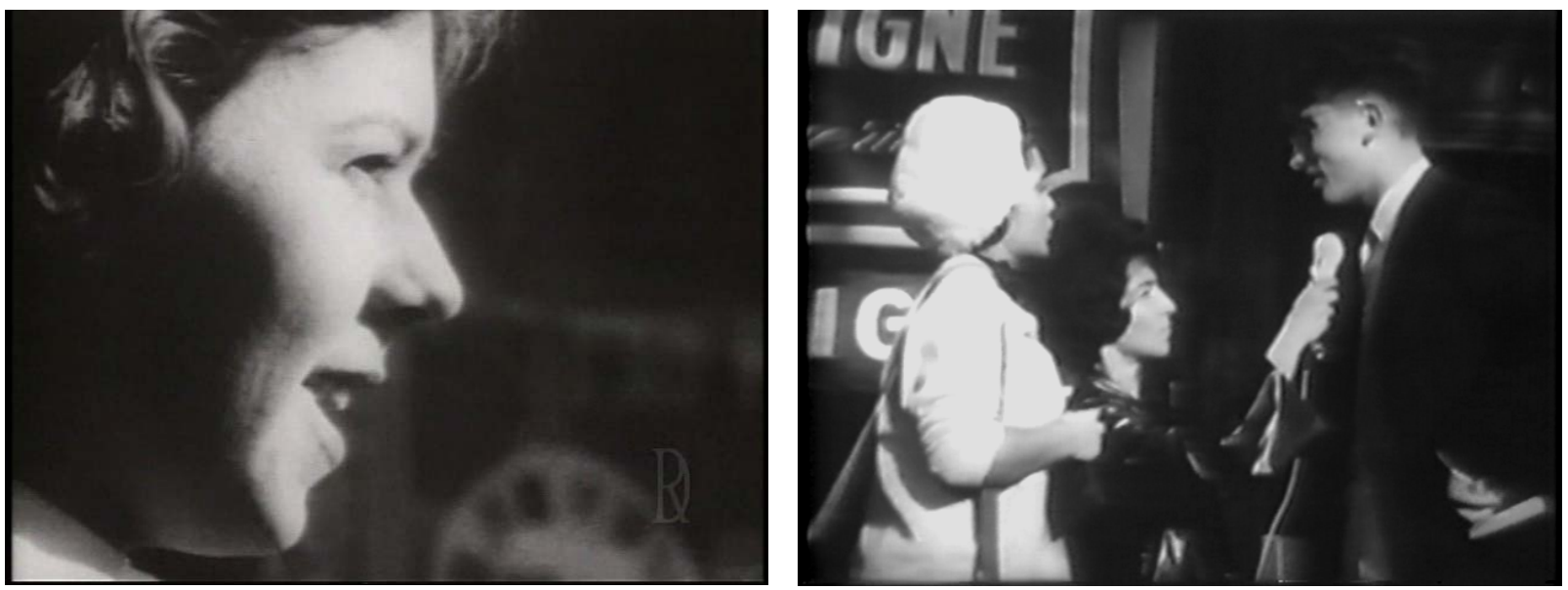

fotos: Primárias e Crônica de um verão

Um último depoimento, agora dentro de um carro e conversando com um motorista de táxi, conduz a narrativa para dentro da sala de votação novamente onde os depoimentos irão permanecer em off, sobrepostos às imagens. Estamos dentro da cabine onde os eleitores votam. Não vemos seus rostos, pois o documentaristacâmera (Albert Maysles) opta por contá-la a partir dos pés dos votantes. Entre os depoimentos off, ouvimos a voz de um locutor (provavelmente da rádio) anunciar que tanto as facções de Kennedy como as de Humprey já se sentem vitoriosas. O último votante retira-se. Os offs também silenciam. Uma caneta, presa à mesa por uma corda, balança pra lá e pra cá marcando a ausência dos corpos e o suposto encerramento da votação. Interessante ressaltar a integração da mídia como dispositivo narrativo e até mesmo como personagem em Primárias, pois a partir dali, esses seriam recursos recorrentes nos filmes do cinema direto, sobretudo àqueles que versavam sobra a vida privada de pessoas públicas, já citados acima. 


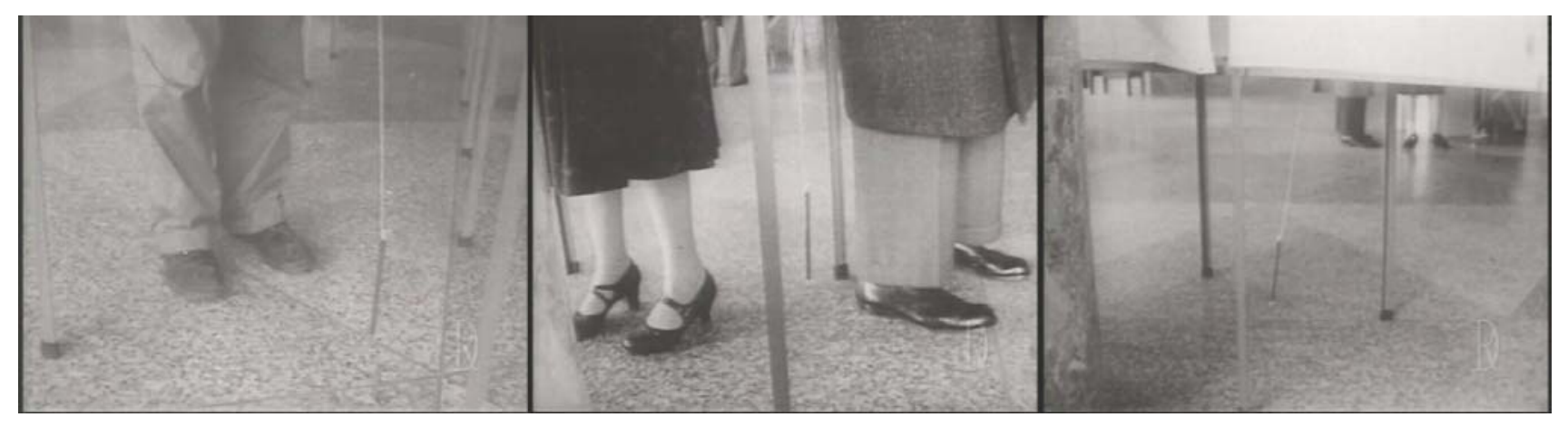

Um outro ponto alto de Primárias é o momento inaugural de uma estética da observação da intimidade, de um corpo-câmera submerso no acontecimento e, aparentemente, ignorado pelos que vivenciam a situação. Drew e sua equipe gravam os candidatos em seus respectivos quartos de hotel, acompanhando o resultado das votações.

Kennedy concordou que um de nós estivesse para filmar o que acontecesse naquele quarto de hotel ganhando ou perdendo. $\mathrm{Na}$ hora marcada eu fui encontrar Leacock que ia ser posto no quarto com sua câmera. Procurei na cafeteria e lá estava Rick sentado e eu perguntei: 'Rick, e o quarto do Kennedy?' E ele disse 'ah! Detesto ter que invadir a privacidade deles!'.

Tímido, Leacock se coloca num canto do quarto, sentado, operando microfone e câmera a um só tempo, acompanhando a movimentação que se desenrolava diante da câmera. Estética em chave distanciada que se manteria nos filmes precedentes dessa primeira fase do cinema direto explorando tanto os momentos privados de pessoas públicas (Bob Dylan, Beatles, o próprio J.F. Kennedy, Rollings Stones etc.), como o de pessoas comuns: vendedor de bíblias em Salesman e do cotidiano de uma família em 
Grey Gardens. Edgard Morin falará em uma "socialidade intensiva"27, que permite que nos filmes de observação a câmera e a equipe de filmagem sejam familiarizadas a tal ponto pelas personagens envolvidas no evento registrado que tenham um efeito imperceptível. Mas, sem dúvida, essa estética da observação intimidade também precederia aquelas dos reallitys shows contemporâneos ou mesmo das câmeras de vigilância $^{28}$. Um olhar prospectivo do cinema observacional nos ajuda a pensar além da ingênua crença na objetividade e na construção de uma verdade alcançada graças ao distanciamento entre sujeito e objeto da observação, que alguns precursores possam ter professado no nascer do cinema direto norte-americano.

Havia entre eles - e honrando as diretrizes do mestre Drew - a preocupação em desenvolver uma dramaturgia documental em íntimo diálogo com estratégias narrativas ficcionais alcançadas na filmagem e na montagem. Nesse sentido, os filmes dos irmãos Mayles são exemplos desse processo, sobretudo Salesman (Caixeiro Viajante), que seus autores consideram um documentário ficcional ${ }^{29}$ por agenciar sua montagem em íntimo diálogo com as estratégias de construção narrativa do romance clássico, bem como Grey Gardens, onde apesar do método observacional a interação entre personagens e documentaristas integra o acontecimento narrativo e deflagra as inevitáveis negociações entre documentaristas e documentados que, embora não reveladas ao espectador, eram essenciais para os resultados finais alcançados.

\footnotetext{
27 Apud McDOUGALL, David. In: FRANCE, Claudine. Op.cit., p.93.

28 Vale lembrar que recentemente João Moreira Salles filmou Entreatos (2004), acompanhando a campanha presidencial de Lula até a vitória nas eleições. Apesar de ter muitas horas de imagens da movimentação da equipe e contrariando as intenções do diretor que gostaria de integrar esse material ao filme, ele foi usado com muita parcimônia na montagem final. Da mesma maneira, as cenas da campanha pública foram eliminadas e Entreatos privilegia, como comenta João Salles, os momentos mais reservados da campanha como carros, hotéis, aviões, etc.

29 João Salles entrevista Albert Maysles. Extras do DVD Caixeiro Viajante, 1968, (Salesman). São Paulo, Videofilmes, 2006.
} 

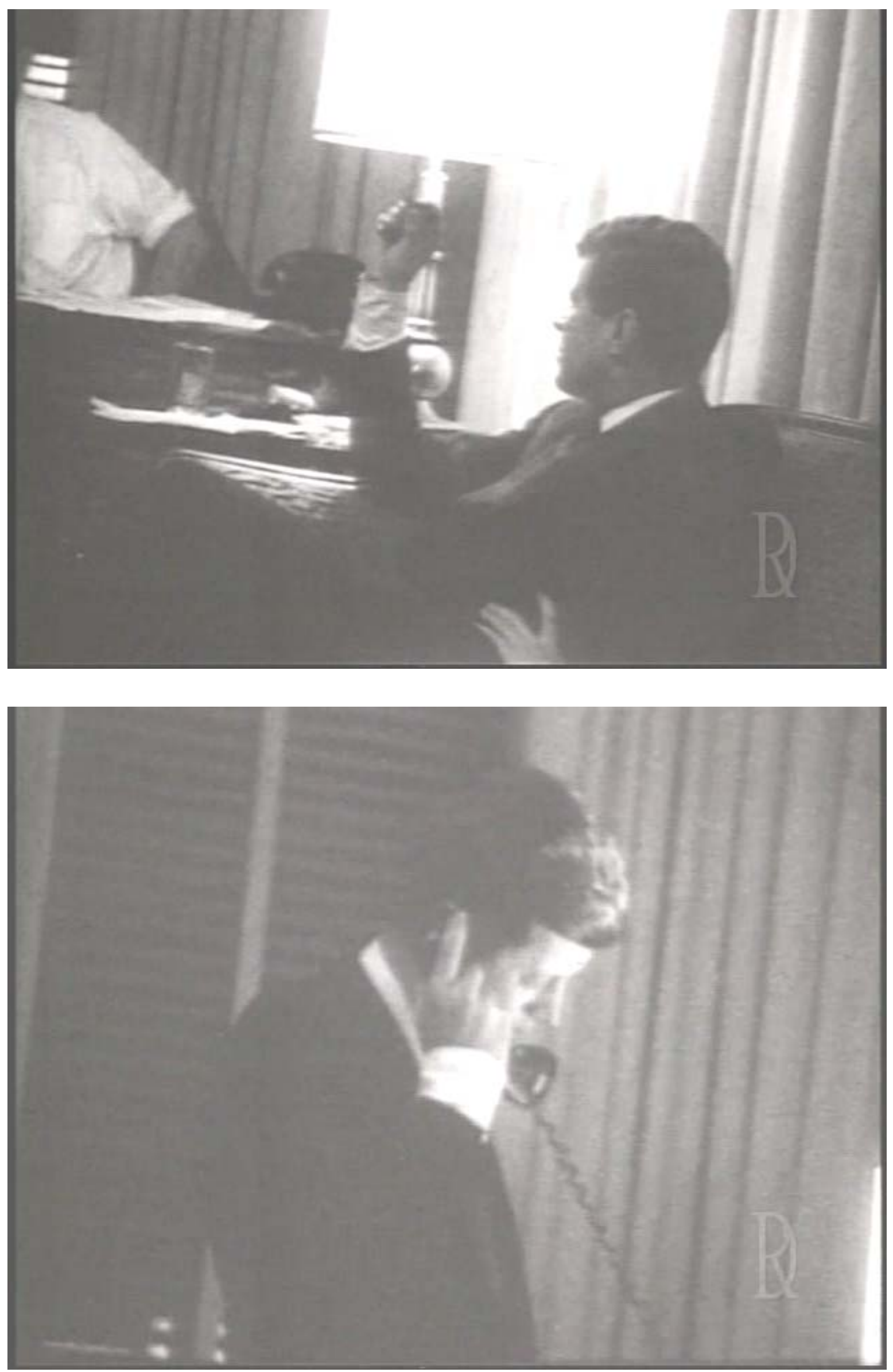
Em entrevista recente a João Moreira Sales ${ }^{30}$, Albert Maysles convoca a necessidade da inter-relação e de se firmar um pacto entre documentaristas e personagens como forma de alcançar o efeito de naturalidade e de ausência da câmera que, segundo ele, jamais é esquecida por aqueles que estão sendo filmados.

Não existe uma maneira de você se esconder totalmente. Você está presente de forma que faz uso da sua presença para incutir sem ter a necessidade de falar nossa afinidade, conquistando a confiança dos personagens a ponto deles sentirem que tudo está bem e que devem continuar nesta mesma linha que não tem importância a nossa presença. Muitas pessoas já me elogiaram achando que eu fosse uma mosca na parede (...) Ora, uma mosca na parede é algo sem coração e sem alma, logo não é nada parecido com aquilo que nós fazemos. $\mathrm{O}$ coração e a alma que nós possuímos têm que atingir a pessoa que nós estamos filmando e a imagem de forma que você seleciona de acordo com o que está sentindo. Embora as pessoas achem 'que coisa maravilhosa de capturar tudo aquilo e ninguém perceber a presença de uma câmera!'. As pessoas dizem que esquecem a presença da câmera, mas existe uma certa consciência de que ela está registrando. Se esta pequena coisa não estivesse ligada e continuasse a rodar não haveria a interação que o operador de câmera tem com o objeto filmado ${ }^{31}$.

Robert Drew, da mesma maneira, reafirma a imagem do cinema observacional como resultado da alteridade e do compartilhar

\footnotetext{
${ }^{30}$ Extras do DVD Caixeiro viajante (Salesman). Videofilmes.

${ }^{31}$ Idem, grifos meus.
} 
o que cinema-verité32 significa pra mim, e creio que para muitos de nós (precursores) é o fato de podermos estar com as pessoas durante períodos críticos, estranhos ou maravilhosos e compartilhar seus sentimentos, seus pontos de vista e suas alegrias diretamente, vendo você mesmo. E se você faz isso de cabeça para baixo ou com a câmera em movimento, em fita ou em filme a tecnologia não tem mais importância.

Tais posicionamentos que convocam a partilha com o outro a partir do sensível e da confiança mútua entre filmantes e filmados vão também estar presentes, ainda que em chave interativa e não mais observacional, nos princípios professados pelos mentores de Crônica de um verão, Edgard Morin e Jean Rouch.

\subsection{Prévias de Crônica de um verão: o encontro de Morin e Rouch}

Conforme estamos analisando, o direto e o verdade são duas tradições narrativas que nascem ao mesmo tempo, com dispositivos técnicos similares, mas partindo de pressupostos antagônicos. O direto, de um lado, preconiza um cinema de não-interferência do realizador que jamais deve acusar sua presença no desenrolar do acontecimento e aposta na invisibilidade do realizador como método central na relação com os sujeitos filmados. O verdade, ao contrário, coloca o documentarista e o próprio processo da filmagem em cena e sugere a interação, através da palavra, como estratégia narrativa.

32 A expressão "cinema verdade" foi incorporada também pelos norte-americanos praticantes do direto. 
Podemos observar que a tradição do cinema direto norte-americano nasce do desejo de criar novos modelos às reportagens de televisão, enquanto o cinemaverdade é resultado do encontro de intelectuais que atuavam nas áreas das ciências humanas e que unem suas experiências individuais para construir a carta de intenções de um novo movimento cinematográfico. Morin, preocupado em se utilizar do cinema como dispositivo de reflexão do homem pelo homem em um jogo de projeções e espelhamentos possibilitados pela imagem e Rouch dando continuidade e atualidade em seu próprio país, aos métodos de antropologia partilhada e improviso de atuação que vinha desenvolvendo na África, realizam um filme que construiria o paradigma máximo do cinema-verdade. Com essa união Crônica de um verão desenvolve uma dramaturgia documental centrada nos registros da fala e da intervenção, influenciando definitivamente as formas de narrar o mundo.

Um filme que reflete a iniciativa do sociólogo Edgard Morin, que convida, através do produtor Anatole Dauman, o cineasta-antropólogo Jean Rouch para fazer um filme juntos em Paris e não mais na África, campo de pesquisa e da maior parte das produções cinematográficas de Rouch antes e depois de Crônica de um verão $0^{33}$. Os dois haviam participado do $1^{\circ}$ Festival Internacional do Filme Etnográfico de Florença, em 1959, e Morin voltara impactado com o que vira por lá: "tive a impressão que um novo cinema verdade era possível", afirma em referência direta ao kino-pravda de Vertov em sua depuração à utilização de atores e encenações.

\footnotetext{
${ }^{33}$ Além do documentário Crônica de um verão, Rouch filmou as seguintes ficções em Paris: La punition, 1962, Paris vu par... - Gare du Nord, 1965, Les veuves de 15 ans , 1966, e Petit à petit, 1969.
} 
Impressões que deixa registrado em Pour un nouveau cinema-verité34, artigo manifesto publicado na revista France-Observateur, em janeiro de 1960, onde convoca a necessidade de retomar experiências documentais que investissem na autenticidade do vivido. O que já fizera Vertov e sua captação da vida ao improviso, bem como aquelas de Flaherty, que em suas realizações procurava "penetrar para além das aparências e entrar no universo desconhecido do cotidiano", desenhando desde já os princípios que formatariam o seu próprio filme com Rouch.

Para Morin, apesar das felizes experiências do cinema soviético e do neorealismo italiano de introduzirem atores não profissionais e fazerem as pessoas interpretarem as suas próprias vidas, ainda "faltava um não sei que de irredutível" que acreditava ser possível encontrar nas captações não-ficcionais. Convicção fundamentada na crença de que para além de "todas as ambivalências do real e do imaginário", há em qualquer "apreensão do vivido a introdução de um elemento radicalmente novo na relação entre o espectador e a imagem" 35 .

A essa época, Morin, antigo membro da resistência, expulso do partido comunista por ser anti-estalinista, editor da revista Arguments e admirador da obra de Rouch, já havia dedicado dois livros à reflexão cinematográfica: $O$ cinema e $o$ homem imaginário, 1956 e As estrelas: mito e sedução no cinema, 1957. As obras desenvolvem o cerne de sua tese acerca da constituição do imaginário do espectador a partir de projeções e identificações com o filme ficcional. Contudo, impregnado pelo desejo documental, estava interessado em explorar uma realização cinematográfica onde os próprios pesquisadores integrassem o fenômeno estudado.

\footnotetext{
${ }^{34}$ MORIN, Edgard; ROUCH, Jean. Chronique d'un été. Paris: Domaine cinema, 1962. p.5.

35 Op.cit., p.8.
} 
Habitado pelas imagens dos filmes de Rouch, sobretudo Eu, um negro, 1958, (Prix Louis Delluc ${ }^{36}$ ) e A pirâmide Humana, 1959, bem como pelos documentários que assistira no festival - "nós tivemos a impressão de que havia um novo movimento para reinterrogar o homem através do cinema" 37 - volta motivado com a experiência urbana e a proximidade atingida nas relações das personagens em We are the Lambeth boys, 1959, de Karel Reisz, do coletivo Free Cinema e representante britânico em Florença.

O Free Cinema foi constituído por um grupo de jovens cinéfilos que passam a realizar seus próprios filmes. Eram revolucionários no sentido de repensarem as convenções do establishment cinematográfico e proporem rupturas tanto na área da produção buscando recursos próprios, independentes do Estado, como também no desenvolvimento de outros paradigmas de roteiro e filmagem. Intelectuais ingleses colaboravam na revista Sequence, que deu origem a Sight and Sound. Em 1956 escrevem um manifesto onde reivindicavam "um cinema autônomo e leve financeira e tecnicamente, liberto de pensadores profissionais e de preconceitos de classe" 38 .

A prática do grupo inglês, como lembra Niney, "visava transgredir as noções de "sujeito" (personagem-herói) e de roteiro pré-fabricado, aproximando-se de pessoas comuns" para, nessa estética, desestabilizar as encenações e valorizar situações improvisadas ${ }^{39}$. Princípios que Reisz aplica ao filmar os jovens de um clube

\footnotetext{
36 O Prêmio Louis-Delluc foi fundado em 1937 por Maurice Bessy e Marcel Idzkowski em homenagem a Louis Delluc, primeiro jornalista francês especializado em crítica cinematográfica e fundador de diversos cineclubes do país. O prêmio, dedicado ao melhor filme do ano, já honrou nomes como JeanLuc Godard, Claude Chabrol, Alain Resnais, Michel Deville, etc., bem como diretores estreantes, caso, na época, de Jean Rouch.

37 Op. cit., p. 6.

${ }^{38}$ Cf. NINEY, François. L'epreuve du réel à l'écran. Bruxelles: Éditions De Boeck Université, 2002. p.134135.

${ }^{39}$ Op.Cit. p. 134.
} 
de periferia de Londres, beneficiado pela câmera leve e que, no entender de Morin, desencadeia um movimento inovador nas narrativas documentais. "Pressente-se que o documentário quer abandonar o mundo da produção (...) para reencontrar o mundo da intimidade das relações humanas" 40 , comenta Morin, que atribui esse sucesso da produção inglesa, em parte, ao método desenvolvido nas práticas etnográficas e, por outro, ao caráter experimental e alternativo da obra já delineando alguns dogmas da nova cinematografia francesa.

"Isto não poderia ser obtido não fosse a observação participante, a
integração do cineasta nos clubes de jovens e ao preço de mil
imperfeições ou, sobretudo, do abandono das regras do
enquadramento. Mas essa reportagem nos abre uma via
prodigiosamente difícil, prodigiosamente nova"41.

É essa face inovadora traduzida pelas imagens de uma sociabilidade documental, na maneira em que o realizador-câmera se faz presente e inscreve sua presença nas imagens (estética depurada no cinema observacional), alcançada em algumas seqüências do filme de Reisz, que mobiliza o sociólogo a chamar Rouch para inscreverem na tela o "universo desconhecido do cotidiano" 42 parisiense. A proximidade possibilitada pela intimidade e convívio com o mundo pesquisado, bem como a criação de uma escritura documental livre e inventiva Rouch já vinha desenvolvendo em suas cine-produções no Mali e na Nigéria alcançando, para Morin, o estatuto de um "cineasta-mergulhador que submerge em um ambiente real" $^{43}$. Qualidades que o tornavam um companheiro ideal na construção desse novo

\footnotetext{
${ }^{40}$ Ibid. Ibidem. p. 7.

${ }^{41}$ Ibid. Ibidem. Grifo nosso.

42 Ibid. Ibidem. p. 7. Grifo nosso.

${ }^{43}$ Ibid. Ibidem
} 
projeto que previa a utilização do cinema como um dispositivo de aproximação com o outro - "o cinema pode ser um dos meios de quebrar esta membrana que nos isola uns dos outros nos metrôs, nas ruas, nas escadas dos prédios?" 44 - bem como na revelação do estilo de vida do homem urbano contemporâneo. Ou antes, na interrogação coletiva desse espírito.

Quando recebe o convite de Morin para filmar em Paris, Rouch já havia realizado uma série de filmes no continente africano, alguns deles conhecidos do público francês. Seu primeiro curta-metragem, Au pays des mages noirs, 1947, foi exibido nos cinemas como complemento de Strombolli, de Roberto Rossellini e dois anos após, em 1949, Initiation à la danse des possédés, 1948, ganha o grande prêmio do Festival du Film Maudit de Biarritz, presidido por Jean Cocteau. Da mesma maneira, Os mestres loucos (Les maîtres Fous), 1955, obtém o grande prêmio da Bienal Internacional de Veneza em 1957 e, como já falamos acima, seu segundo longametragem ${ }^{45}$, Eu, um negro (Moi, un noir), obteria no ano seguinte o concorrido prêmio Louis Delluc.

Nas origens de seu método, Rouch costuma evocar dois pais fundadores do documentário, Robert Flaherty e Dziga Vertov. “Um geógrafo explorador e um poeta futurista" que colocaram, segundo ele, questões essenciais com as quais ainda nos defrontamos quando vamos filmar um documentário: “é necessário encenar a realidade (a encenação da vida real) como fez Flaherty ou filmá-la como Vertov, espontaneamente (a vida captada ao improviso)"46? Rouch parece encontrar a meio

\footnotetext{
${ }^{44}$ In: MORIN; ROUCH, op. cit., p. 8-9.

${ }^{45} \mathrm{Na}$ verdade, o primeiro longa-metragem de Jean Rouch, Jaguar, foi filmado em 1955, mas lançado em 1967.

${ }^{46} \mathrm{ROUCH}$, op. cit., p. 57.
} 
caminho dessas propostas uma linguagem própria e original ancorando sua obra a partir do improviso, do cinema como dispositivo de interação e partilha com o outro, elementos que remetem de uma maneira ou de outra a esses "pais fundadores".

Vertov que, segundo Rouch, é um “visionário da era do cinema verdade"47, em seu Manifesto do cinema-olho (kinoks 1923), realiza um elogio às potências do cinema, professando o dogma da captação da vida ao improviso, execrando as encenações com atores e reconstituições.

“O cinema-verdade é um novo título de arte, a arte da vida mesmo. O cinemaolho compreende: todas as técnicas de filmagem; todas as imagens em movimento; todos os métodos, sem exceção, que permitem alcançar a verdade - uma verdade em movimento" 48 .

Honrando sua filiação construtivista, Vertov privilegia a montagem investindo em nas possibilidades de articular um discurso inovador e experimental, como demonstra com excelência em Um homem com a câmera, 1929, filme que será evocado em Crônica de um verão, sobretudo em relação ao próprio processo de filmagem, assim como em integrar os espectadores no acontecimento narrativo. Porém, é também no diálogo com o desejo do vivido, do imprevisto e do espírito urbano, que tanto inspiraram o construtivista russo na elaboração de seus princípios, que a obra de Rouch e Morin reflete os desdobramentos vertovianos.

${ }^{47}$ Op.cit., p.57

48 XAVIER, Ismail. A experiência do cinema. Rio de Janeiro, Graal, 1991, p.249. 
Contudo, se o documentarista russo "prediz a era do cinema-verdade" 49 , é em Flaherty que Rouch irá se espelhar e encontrar as linhas de força de seus métodos narrativos desde muito cedo.

Para Flaherty, em 1920, filmar a vida dos esquimós do Pólo Norte era filmar um esquimó, em particular, não uma coisa, mas um indivíduo, e a honestidade elementar consistia em lhe mostrar o que se fazia.

Propostas que engendram sua noção de "antropologia partilhada", na qual Rouch evoca o mestre em seu princípio de inclusão do outro e de retornar aos personagens suas próprias imagens, para que eles opinem sobre a construção do filme. Filosofia que promovia a desestabilização da autoridade narrativa, incorporando o olhar e as idéias do outro ao filme, na medida em que ia sendo rodado e/ou montado, dispositivo que cunhou como "contra-audiovisual" e que se tornou para o antropólogo um "caminho de iniciação ao coração mesmo do conhecimento"50.

Quando Flaherty improvisou um laboratório de revelação dentro de uma cabana na baía de Hudson, quando ele projetou essas imagens ao seu primeiro espectador, o esquimó Nanook, ele não sabia que, através de meios precários ele vinha de inventar de uma só vez a observação participante (...) e o feedback (das imagens) que experimentamos ainda desajeitadamente ${ }^{51}$.

\footnotetext{
${ }^{49}$ ROUCH, op.cit., p. 57.

${ }^{50}$ ROUCH, Jean. La câmera et les hommes. In: FRANCE, Claudine. (org.). op.cit, p.56-69.

${ }^{51}$ Idem, ibidem.
} 
Para Rouch, Nanook é fruto dessa interação entre criador e criatura, entre documentarista e documentado, realidade possibilitada pelos dispositivos cinematográficos.

Se Flaherty e Nanook chegam a contar a difícil história da luta do homem contra a natureza prodigiosa em benfeitorias e sofrimentos é porque havia entre eles uma terceira personagem, uma pequena máquina caprichosa, mas fiel, de uma memória visual infalível que possibilita Nanook de ver suas próprias imagens na medida em que essas iam nascendo ${ }^{52}$.

Portanto, é no diálogo com a obra de Flaherty que Rouch "rasga" o roteiro e importa a interação e a partilha como métodos de construção narrativa, conduzida, orquestrada e finalizada por ele, é importante dizer.

Jaguar, filmado em 1957, mas que só viria a público dez anos mais tarde, em 1967, inaugura o gênero rouchiano da etno-ficção e aposta na interação entre diretor e personagens (antropologia partilhada), além de investir no método da improvisação como estratégia narrativa. A etno-ficção é um método híbrido em que Rouch convoca não-atores africanos para, desde suas experiências pessoais e a adoção de um método compartilhado de roteiro e improvisação, construírem uma ficção onde o imaginário ganha estatuto documental.

Assim, nesse novo modo narrativo permeado de atravessamentos entre o real e o ficcional, o filme torna-se paradigmático na obra do antropólogo, pois é ali que estabelece os preceitos do método de trabalho consolidado ao longo de sua carreira. Jaguar nasce de uma sugestão do ator Damouré Zika, entusiasmado com a idéia de

52 Idem, ibidem 
fazer um outro trabalho com Rouch após ver A caça ao hipopótamo (La Chasse à L'Hippopotame), 1951, no qual participara.

O filme, um road movie a pé, conta a história de três amigos (Damouré, Lam e Illo) que viajam em direção a Accra, onde esperam alcançar sucesso e dinheiro para poder voltar a sua terra natal. Rouch filma pela primeira vez com um equipamento mais leve que lhe permite portar a câmera no ombro, sem som direto e tampouco diálogo. As cenas a serem filmadas eram decididas dia após dia, em conjunto entre diretor e atores. O som inserido na montagem funda um "diálogo em estilo indireto" $^{53}$. Rouch justifica sua inspiração como sendo ancorada nos elementos oferecidos por uma cultura marcadamente oral, como a africana.

Trabalhando com gente que são os campeões da tradição oral é impossível escrever diálogos. Assim, eu sou obrigado a me submeter à uma certa improvisação que é a da arte da palavra e da arte do gesto. É necessário deslanchar uma série de ações para ver e, de um só golpe, emergir a verdade, da ação inquietante de uma personagem tornar-se inquieta ${ }^{54}$.

Moi un noir vem nos registros da partilha e do improviso inaugurados em Jaguar de perseguir, no nosso entender, a elaboração de uma dramaturgia do imaginário e da fabulação engendrados em um modelo híbrido tanto no pacto entre cineasta e atores, como nos atravessamentos dos registros do documentário e da ficção. A subjetividade das personagens é valorizada através de suas próprias falas em comentários incorporados posteriormente na montagem. Pela primeira vez na

\footnotetext{
${ }^{53}$ NINEY, Op. cit., p. 158.

54 Apud. NINEY, Op.cit., p. 158.
} 
história do documentário (ou dessa etno-ficção) o desejo, a memória e o imaginário professados pelas próprias personagens são elevados a estatuto de documento. $\mathrm{O}$ pensar conjunto, as filmagens a cada dia, ainda em honra ao mestre Flaherty, aprofundam o conceito de partilha rouhniano, como também consolidam estratégias de improvisação, uma das heranças do antropólogo ao período moderno do cinema e, sobretudo, à nascente nouvelle vague.

Michel Marie indica diferentes aspectos sob os quais o cinema de Rouch, entre eles Crônica de um verão, influenciou e dialogou com as novas cinematografias dos anos 60 na França. Além da já citada ficção improvisada, que o autor considera um dos mais fortes traços do cinema moderno francês, a utilização do som direto, o atravessamento do ficcional e do documental e a voz do próprio realizador citando precisamente o texto do autor que ele adapta foram contribuições fundamentais ${ }^{55}$.

O crítico Ruy Gardnier, observa que Moi un Noir e Jaguar tem um aspecto decisivo como influência em Jean-Luc Godard:

o primeiro pelos jump cuts, o segundo pela forma de falar e de agir das personagens, malandros safos que lembram por diversas vezes o Michel Poiccard de Acossado): despojamento na maneira de filmar exteriores, desobrigação para com a gramática de corte e encadeamento de planos, fluência cotidiana da fala - até então dominada por um literatismo de roteiro, ao menos no cinema francês a improvisação das cenas e a ausência de roteiro prévio são constantes da obra de Rouch, e serão traços determinantes de boa prouchianoarte da nouvelle vague que virá logo depois ${ }^{56}$.

55 Cf. MARIE, Michel. La nouvelle vague: une école artistique. Paris: Éditions Nathan, 1997.
56 Cf. GARDNIER, Ruy. Atualidade de Jean Rouch. www.contracampo.com.br. 
Persistindo na temática da juventude desterrada e vivendo à margem nas capitais africanas, $E u, u m n e g r 0^{57}$ conta a história de cinco jovens nigerianos que deixaram o interior para procurar trabalho na Costa do Marfim (Cote d'Ivore), vindo parar em Treichville, bairro popular de Abidjan. Essa etno-fiçcão-documental roça, a um só tempo, um clima de jogo e brincadeira onde esses atores não profissionais dão livre curso à imaginação e nominam-se como Edward Robinson, Eddie Constantine, Tarzan e Dorothy Lamour, todos estrelas do cinema americano. Como em Jaguar, foi sonorizado na pós-produção, com offs de Rouch e os comentários instintivos de Oumarou Ganda, personagem condutor da trama que desempenhava o papel de Edward Robinson.

Na locução off inicial de Rouch, sobreposta às imagens de jovens sentados à calçada iniciando toda uma sequiência que descortina o cenário urbano onde eles se encontram, ficam estabelecidas as autorias, bem como a polifonia narrativa que conduzirá a trama. Narração emblemática também, porque além de marcar a presença do realizador, coloca o método de filmagem como estratégia e acontecimento narrativo, evento que iria se reprisar, sob outros moldes, em Jaguar, A pirâmide humana e Crônicas de um verão.

${ }^{57}$ Lançado em DVD (acompanha Os mestres loucos) no Brasil pela Videofilmes. São Paulo, 2006. 


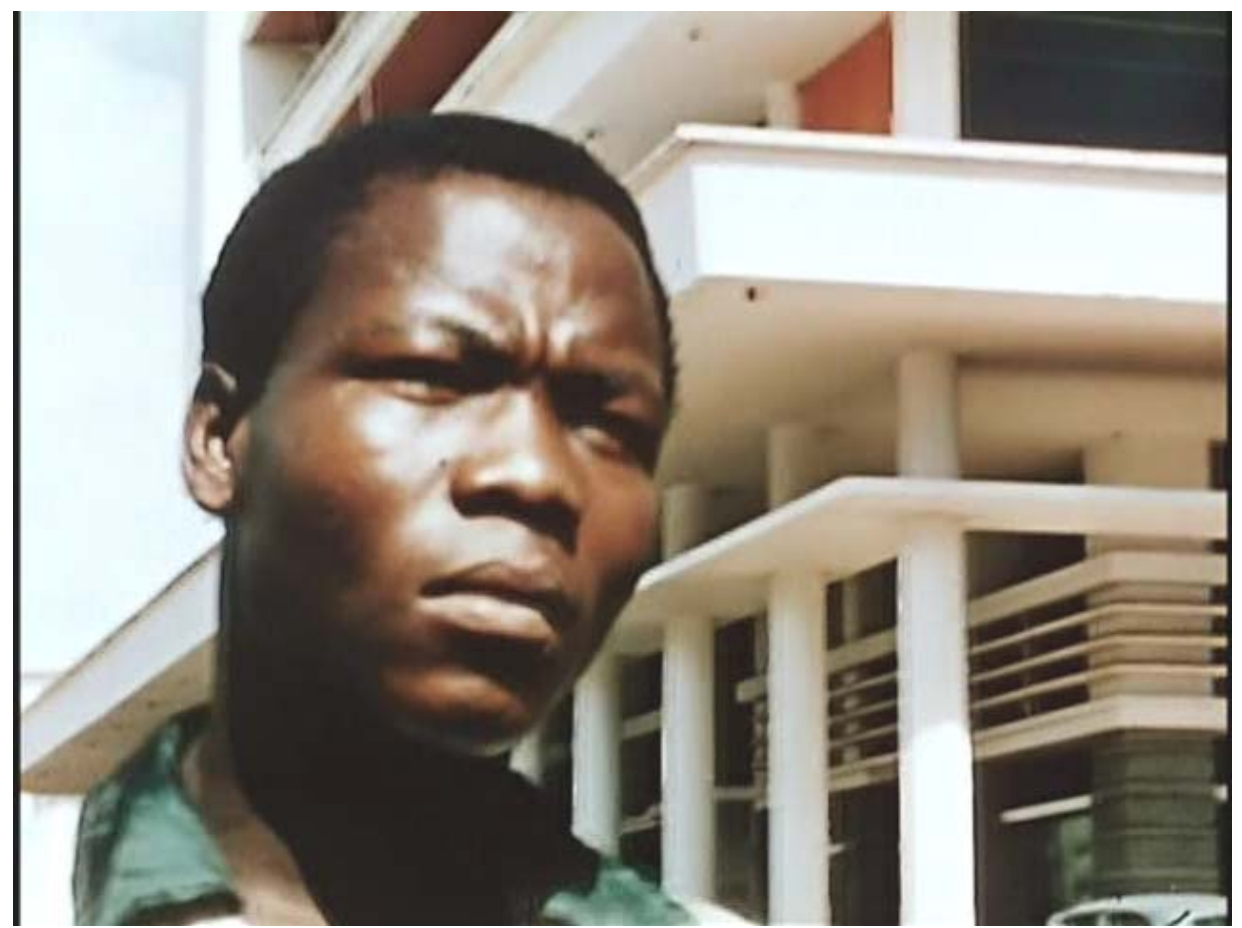

foto: Eu, um negro.

Diz Rouch:

Todo dia jovens parecidos com os personagens desse filme chegam às cidades da África. Eles abandonaram a escola ou a família para tentar entrar no mundo moderno. Não sabem fazer nada e fazem de tudo. (...) Durante seis meses segui um grupo de jovens nigerianos a Treichville, um bairro de Abidjan. Propus fazer um filme que eles representariam a si mesmos, em que eles teriam direito a fazer tudo e a dizer tudo. Foi assim que improvisamos esse filme. Um deles, Eddie Constantine foi tão fiel a seu personagem Lenny Caution, agente federal americano que, durante as filmagens foi condenado a três meses de prisão. Para o outro, Edward G. Robinson o filme tornou-se um espelho no qual se descobriu: o ex-combatente da Indochina, perseguido pelo pai porque perdeu a Guerra. Ele é o herói do filme. Passo a palavra a ele. 
E o jovem Oumarou Ganda, que em um dado momento irá se apresentar e justificar a adoção da identidade de Edward G. Robinson - seus amigos o acham parecido com o ator hollywodiano, nos levará a vivenciar suas peregrinações por Treichville.

Mas é sem dúvida A pirâmide humana que mais transpira referências à Crônica de um verão. Já à primeira cena o dispositivo do filme é explicitado: colocar brancos, europeus e negros africanos em uma mesma classe de aula, na cidade de Abidjan, Costa do Marfim. A experiência, diz Rouch, é pesquisar as relações entre as raças em relação aos preconceitos e afinidades mútuas. Como em Jaguar e Eu, um negro não há roteiro fixo, cada um interpreta e improvisa como quiser dentro do seu papel, mas aqui se estabelece uma dinâmica de psicodrama, em um sofisticado jogo etnoficcional.

Rouch proporá a esses jovens que imprimam seus desejos e reações a partir do tema proposto, dando vazão a não-atores exercitarem toda uma dramaturgia do imaginário e da fabulação já referida anteriormente. Seu filme seguinte, Crônica de um verão, em parceria com Edgard Morin, atualizaria de diferentes maneiras essas heranças estético-conceituais das obras anteriores. Como constata Niney,

Crônica de um verão é um exercício de antropologia partilhada entre documentaristas/ documentados/ espectadores onde a lição se mostra irritante àqueles que tomam a verdade como essência e não como devir, como revelação e não como ação ${ }^{58}$.

58 NINEY, op.cit., p.163. 
Para além dos princípios de partilha, Crônica de um verão roça as intenções psicanalíticas, implementa a técnica do improviso aliada ao som direto e inova com o princípio da intervenção.

\subsection{Crônica de um verão: a cidade do encontro/confronto e a sociabilidade partilhada}

Na realização de Crônica de um verão, Rouch desloca e investe às ambições de Morin a experiência adquirida em territórios africanos para desenharem as pretensões de um filme não-ficcional em espaço urbano. Buscando na vida cotidiana dos moradores de Paris a representação da imagem de si e do outro, trazem ao núcleo das discussões o próprio documento que estava sendo produzido. Situação que evoca, em chave metalingüística, um diálogo com o Um homem com a câmera, na evolução de uma crônica e, no caso, crítica da própria filmagem colocando o processo documental ao centro do acontecimento narrativo do início ao fim.

$\mathrm{Na}$ sinopse que Morin envia ao C.N.C. (Centre National de la Cinématographie), as intenções estético-conceituais demonstram-se amadurecidas em relação ao que seria o resultado final da obra. Em chave reflexiva, o sociólogo propõe uma experiência de interrogação cinematográfica estruturada a partir de uma pergunta chave

Como você vive? quer dizer não somente o modo de vida (moradia, trabalho, laser), mas o estilo de vida, a atitude ao olhar a si mesmo e aos outros, a maneira de conceber seus mais profundos problemas e a resposta a esses problemas. (...) a ambição do filme é que a questão que parte de dois autores-pesquisadores, encarnados em personagens reais 
ao longo do filme - ao ser exibida, leve cada espectador a se colocar essa mesma interrogação 'como você vive?', ‘o que você faz de sua vida?'59.

Fiéis a esse argumento e com espírito de cronistas de seu tempo, Rouch e Morin integram corpo e voz ao próprio relato e indagam a vida cotidiana de seus amigos parisienses para tentar compreender sua concepção de felicidade e visão de mundo confrontadas a deles próprios. São por esses caminhos que nascem as intenções de Crônica de um Verão, com as facilidades da leveza do equipamento 16mm possibilitando maior mobilidade da câmera, a captação em som sincrônico com o gravador portátil Nagra e as filmagens de improviso, sem roteiro prévio.

Uma experiência que faz emergir o contexto do imaginário urbano em discussões sobre estilo de vida, política, memórias do holocausto e as guerras de descolonização no Congo e na Argélia60. Diante das câmeras, desenrolam-se discussões entre pessoas comuns (estudantes, operários, artistas, militantes, africanos desterrados, etc.) acerca de eventos tanto banais como extraordinários que lhes diziam respeito, contrapostos às suas vidas e conflitos diários de insatisfação pessoal, crise profissional, dramas afetivos e preconceitos raciais. Rouch e Morin vão aos bares, aos bailes e nas casas dos amigos-personagens; organizam encontros entre conhecidos e pessoas que jamais haviam se visto e filmam o tempo todo perfazendo 25 horas de material, condensados em 90 minutos.

Com espírito provocador e mantendo a chave do sociodrama já trabalhada em A pirâmide humana, os documentaristas propunham situações capitalizadas ao seu

\footnotetext{
${ }^{59}$ Op. cit., p.9-10. (Grifo nosso).

60 O filme foi rodado durante a guerra da Argélia pela descolonização francesa.
} 
desejo de buscar maior proximidade com as personagens e entre elas. Desejo que lhes impulsiona transgredir os limites do quadro cinematográfico e invadir o espaço cênico. Visto dessa perspectiva, Crônica de um verão é um momento emblemático, onde o documentarista passa a atuar e torna-se ele também personagem ${ }^{61}$ de seu filme estabelecendo um sistema de trocas e reciprocidades com os entrevistados. $\mathrm{O}$ autor responsável pela construção da cena cinematográfica, tradicionalmente engendrada como recorte do mundo do outro, ocupa o interior de seu próprio olhar pensando o seu pensamento.

Portanto, Rouch e Morin não se colocam como quem fala sobre algo que lhes é exterior, mas inscrevem-se desde dentro de suas próprias imagens e atuam ao lado das outras personagens, expondo seus conceitos de filmagem e deixando-se contaminar pelo espírito da performance de diretor diante das câmeras. Esta relação entre os pesquisadores-documentaristas e os participantes convocados à "experiência de cinema-verdade" 62 provoca, ao longo do filme, confrontos e desencontros de estilos de vida, bem como acerca do estatuto da autenticidade ou não da representação do si mesmo e do outro diante das câmeras. Documentaristas-imagem que funcionam como "catalisadores da ação através de suas presenças com a câmera e sua interação perpétua com os filmados"63.

Nasce simbolicamente a cidade do encontro e do confronto documental urbano atualizado de maneiras diversas nos dias de hoje. Uma relação onde o documentarista engancha-se em um lugar que originalmente seria somente do outro

${ }^{61}$ Cf. DA-RIN, Sílvio. O espelho partido. Rio de Janeiro: Azougue Editori, 2004. p.152. DI TELLA, Andréas. In: MOURÃO; LABAKI (orgs.). O cinema do Real. São Paulo: CosacNaif, p. 78.

${ }^{62}$ Expressão retirada do off inicial de Crônica de um verão.

${ }^{63}$ Cf. Ciné-Rouch,(DVD), de Pierre-André Boutang. 
para, desde aí, buscar a distância crítica e estranhar o seu próprio universo de pertença. Encontros/confrontos no nosso entender, possibilitados pela migração do realizador receptivo aos imponderáveis e acasos do jogo documental e, principalmente, das inter-relações inscritas no processo fílmico.

Quase sempre em quadro, expondo suas intenções e pontos de vista, Rouch e Morin atuam suas subjetividades: intervém, conversam, estimulam as discussões, provocam reuniões entre pessoas que não se conheciam e se provocam a si mesmos. Indo na direção, até mesmo, de suas vidas privadas: as cenas no sul da França foram filmadas na casa de Morin, com a presença de seus filhos. O Museu do Homem, locação do diálogo final entre os dois documentaristas-pesquisadores, era local de trabalho de Rouch e, da mesma forma, quase todas as personagens do filme, seus amigos e conhecidos.

Essa estética do encontro e do confronto pontuará todo o filme inaugurando a cena documental como um lugar polifônico, dialógico, de escuta e também de incompreensão do outro. Um espaço de sociabilidade documental que privilegia a proximidade inovando os padrões da época. Proximidade contaminada de elegâncias e simpatias mútuas, mas também de discórdias, rancores e preconceitos, elementos que agem comumente na formatação dos laços sociais urbanos, como já havia captado Simmel em sua análise das relações metropolitanas ${ }^{64}$.

Enquanto roça esses limites da verdade cinematográfica, Crônica de um verão traz vida nova ao documentário investindo na noção de intervenção através da palavra (propiciada pelas novas tecnologias de captação do som sincronizado à imagem) e em desdobramentos aos métodos rouchianos de antropologia partilhada e improviso que 64 SIMMEL, 1983, p.168. 
vinham sendo desenvolvidos nas suas etno-ficções Jaguar, Eu, um negro e A pirâmide humana.

Bob W. White marca três registros dos filmes de Rouch: os etnográficos, que têm sua data de término com Os mestres loucos; um segundo na "invenção" da etnoficção, que exerceria até o fim de seus dias e, por fim, o terceiro marcado pelo cinema-verdade inaugurado em Crônica de um verão. Momento em que Rouch aplica métodos etnográficos a sua própria sociedade 65 e, no nosso entender, realiza uma alquimia dos dispositivos empregados em suas obras anteriores acrescidos das possibilidades do som direto.

A palavra sincronizada com a imagem e o explorar a oralidade em todas as suas riquezas no próprio acontecer do evento marcam a tradição do cinema verdade, em registro oposto a Primárias, seu parceiro de época e técnica, que captava os sons do evento, sem jamais provocá-los. Morin enfatiza “o ato, afinal, é a palavra; o ato se traduz através dos diálogos, das discussões, conversas etc. O que me interessa não é o documentário que mostra as aparências, é uma intervenção ativa para ir além das aparências e extrair delas a verdade escondida ou adormecida" 66.

Em Crônica de um verão a palavra atua como protagonista, inaugurando no documentário moderno todo um jogo de proximidade nos dispositivos de interrelação em ambiente urbano, bem como construindo dinamizações cênicas mobilizadas pelas artes do dizer, nas escolhas e valorizações do quê e como falar. Dispositivos como entrevistas, conversas, debates, enquetes, que nos dias de hoje são super banais, ali tinham um frescor de propostas narrativas que estavam nascendo. A

\footnotetext{
${ }^{65}$ WHITE, Bob W. Hommage à Jean Rouch: caméra intouchable. www.horschamp.qc.ca/article.

${ }^{66} \mathrm{ROUCH}$; MORIN, op.cit., p. 29-30.
} 
palavra compõe-se, assim, como elemento fundante na construção e expressão dos dilemas e conflitos destas personagens modernas, articuladas às paisagens que as inserem em uma vida cotidiana na cidade.

E é pela palavra que Crônica de um Verão articula uma estética da intimidade diferenciada daquela elaborada no cinema de observação ${ }^{67}$, promovendo conversas íntimas tanto em lugares públicos, como dentro das casas das personagens. Uma das cenas mais emblemáticas nesse sentido é o primeiro dos dois encontros de Edgard Morin com Mary-Lou. No primeiro, a jovem italiana mostra-se depressiva e desiludida com a vida. Já na entrevista seguinte, Mary-Lou está feliz e otimista, pois vive uma nova paixão. Quando a vemos pela primeira vez ela está saindo de seu apartamento. Em estilo observacional a acompanhamos caminhando na rua e trabalhando no seu ofício de secretária (no Cahiers du cinéma). Sentada em frente à máquina de escrever, ouvimos a voz off de Morin, locução que invade a cena seguinte com Mary-Lou sentada em seu apartamento, rosto apoiado na mão e olhar atento ao seu interlocutor.

Morin é indiscreto, provocador e curioso. Em sua fala quer construir a diferença da personagem para desde ali questionar suas opções de vida, liberdade e felicidade. O sociólogo-documentarista assume as vezes de um amigo, de um conselheiro, de um psicanalista inaugurando, naquele momento, um estilo de entrevista confessional e realizando o seu projeto de através da "intervenção ativa"68

\footnotetext{
${ }^{67}$ Cena registrada por Leacock no quarto de Kennedy no momento da contagem de votos, citada anteriormente.

${ }^{68}$ Cf. Nota 37.
} 
fazer da filmagem uma "oportunidade de relação interpessoal"69 para "reencontrar o mundo da intimidade das relações humanas"70.

Um outro momento paradigmático de Crônica de um verão é vivido por Marceline Loridan em suas rememorações da deportação dela e do pai aos campos de concentração. Referenciado em suas etno-ficções, onde investe no método de improviso e em toda uma dramaturgia do imaginário abrindo espaço às personagens de reinventarem-se a si próprias na expressão de seus conflitos, Rouch estimula Marceline a relembrar esse momento dramático no próprio local onde ele aconteceu, na Praça da Concórdia. Marceline caminha cabisbaixa, professando suas memórias diante da câmera, deslocando o método do improviso rouchiano ao presente do acontecimento, em som sincrônico e propiciando que documentário e ficção se atravessassem radical e definitivamente.

Deleuze afirma que nos filmes que optam pelo registro do que estamos chamando de dramaturgia do improviso e da fabulação: “a ruptura não está entre ficção e a realidade, mas num novo modo de narrativa que as afeta". Esse novo modo de narrativa é aquele que encontra sua função de fabulação como um modelo de verdade ${ }^{71}$.

É preciso que a personagem seja primeiro real para afirmar a ficção como potência e não como modelo: é preciso que ela comece a fabular para se afirmar ainda mais como real, e não como fictícia. A personagem está sempre se tornando outra, e não é mais separável desse devir que se confunde com um povo. Mas o que dizemos da personagem vale, em segundo lugar e notavelmente para próprio

\footnotetext{
${ }^{69}$ ALTHABE, Gerard. La ville rompue. In: COMOLLI , Jean-Louis; ALTHABE, Gerard. Regards sur la ville. Paris: Editions du Centre Georges Pompidou, 1994. p. 79. Grifo meu.

${ }^{70}$ Vide nota 10. Grifo meu.

${ }^{71}$ DELEUZE, Gilles. A imagem-tempo. São Paulo: Brasiliense, 1990. pp. 183-184.
} 
cineasta. Também ele se torna um outro na medida em que toma personagens reais como intercessores, e substitui suas ficções pelas próprias fabulações deles ${ }^{72}$.

Esse papel de intercessor, caro à obra rouchiana, adquire uma outra forma no uso da palavra sincrônica de Crônica de um verão quando migra a sua forma de presença da voz off (que vinha utilizando até então) a uma voz-corpo como dispositivo de interação ou, antes, de intercessão com as personagens. Nos filmes anteriores, sobretudo em Jaguar, Eu, um negro e A pirâmide humana, Rouch já (se) professava em voz off os dispositivos de realização e a forma de participação de suas personagens na criação do filme abrindo chave reflexiva à obra. Estratégia reprisada em Crônica de um verão, que apresenta uma riqueza de dispositivos ao longo do filme, ampliando ainda mais o repertório criativo do antropólogo em parceria com Morin.

Essas revelações dos conceitos e dispositvos cinematográficos não só incorporados como também propulsores do acontecimento documental são questões centrais à obra e ao nascimento de uma tradição do cinema-verdade francês. A tendência de revelar o processo de produção e concepção do filme, fazendo com que ele se torne o acontecimento narrativo central, pontuará a obra do início ao fim. Já nas seqüências iniciais, sob imagens que cartografam uma típica paisagem parisiense do movimento da saída do metrô, Rouch falará ao espectador que o filme "não foi feito por atores, mas vivido por homens e mulheres que deram um momento de sua existência a uma experiência nova de cinema-verdade". As cenas subseqüentes serão marcadas por essa dimensão reflexiva onde a representação da experiência fílmica será incorporada ao documentário.

72 Op.cit., p. 185. 
Jean Rouch, Edgar Morin e Marceline Loridan estão sentados em torno de uma mesa baixa. Ali estabelecem o estatuto do documento, expondo suas intenções e objetivos, indicando também que há um processo de seleção, negociações e acordos na construção da representação cinematográfica.

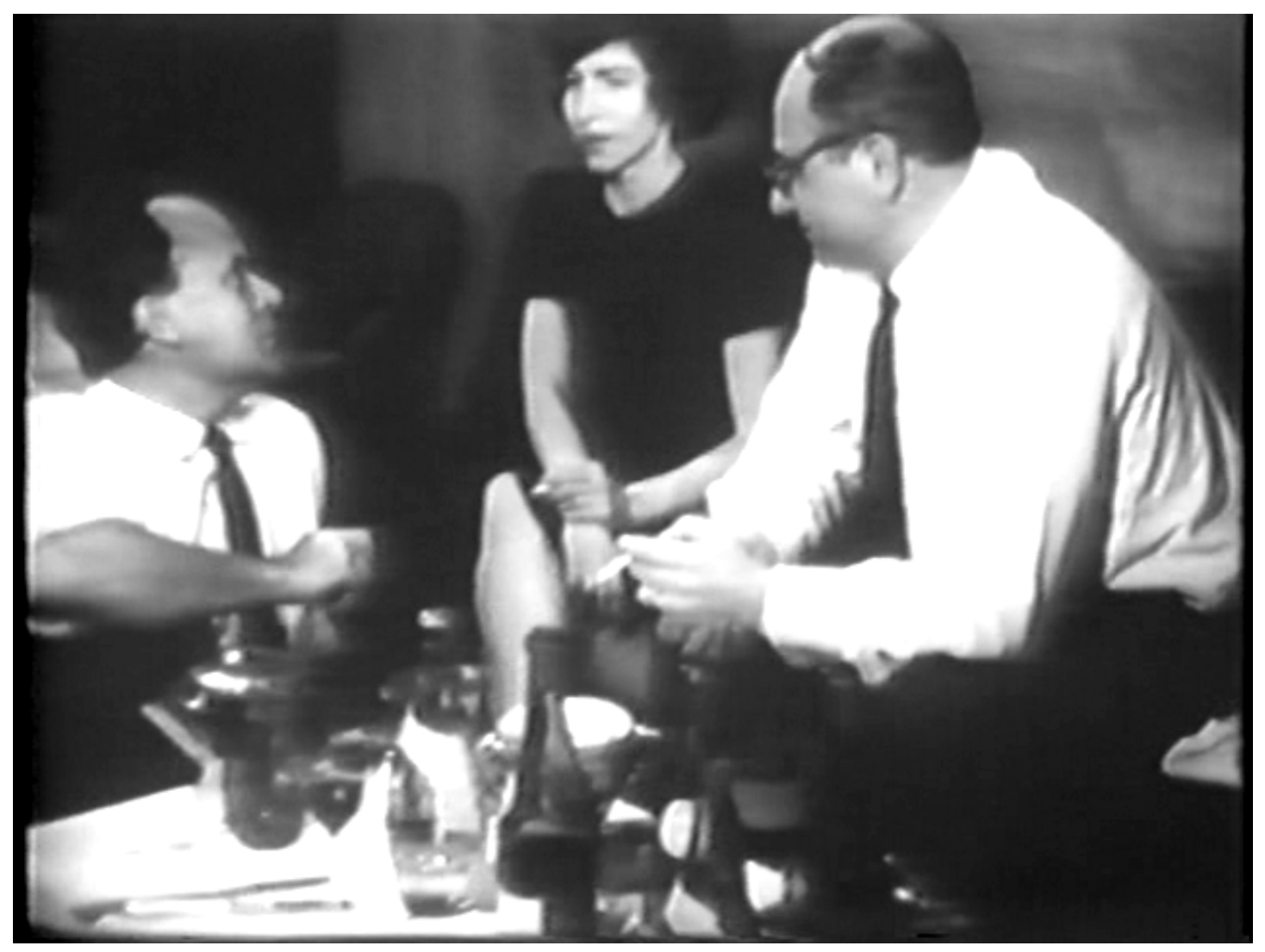

Diz Rouch: "Você vê, Morin, a idéia de reunir pessoas em volta da mesa é uma ótima idéia só não sei se conseguiremos gravar uma conversa como se não houvesse câmera. Não sei se Marceline conseguirá falar normalmente". Marceline se diz intimidada e Rouch esclarece que ela terá acesso às imagens e poderá opinar: "o que pedimos Morin e eu, com astúcia, é que simplesmente responda às perguntas. E se diz coisas que não agradam é só cortar". A fala de Morin ao mesmo tempo em que esclarece ainda 
mais os métodos do filme, introduzindo Marceline como personagem e entrevistadora-assistente, delineia um novo tipo de documentarista: o narrador em dúvida ${ }^{73}$.

Diz Morin:

Você não sabe o que nós vamos perguntar. Nós também não. O que queremos é fazer um filme que responda como você vive? Começamos por você e haverá outros. Como você vive? Como enfrenta a vida Começamos por você porque vai participar intensamente do filme.

Por essa perspectiva, Crônica de um Verão é também um documentário sobre o processo de experiência fílmica. Os elementos que tradicionalmente estariam fora de quadro ou atrás das câmeras são inscritos na imagem. O processo de realização e mesmo as imagens do filme conquistam visibilidade no interior da própria obra. É ali que as questões que circundam as estratégias de representação documental (que os diretores elegeram como elementos narrativos) são apresentadas, debatidas, contestadas e questionadas na sua (im)possibilidade de representar a vida e alcançar uma certa essência de verdade.

Um outro momento se tornaria emblemático na constituição do estilo da nova tradição e na metodologia rouchiana (Morin, decepcionado com a experiência cinematográfica, nunca mais voltaria a filmar). O princípio nominado por Rouch como contra-audiovisual de retornar às imagens, às personagens do filme e problematizar os efeitos da presença dos documentaristas e da câmera é pela

\footnotetext{
${ }^{73}$ A ótima expressão é de Cléber Eduardo em seu artigo "Crônica de um verão: reflexo e invenção de seu próprio tempo". Em: www.contracampo.com.br
} 
primeira vez incluído na montagem final. Intitulada no roteiro "a verdade em questão"74, nessa cena os realizadores mostram o copião aos participantes da "experiência" documental e os estimulam a refletir sobre suas impressões acerca da autenticidade das imagens e a veracidade que as personagens emprestaram às suas performances cinematográficas. Provocados pelos documentaristas discutem, aceitam ou rejeitam as atuações apresentadas, circundando, ampliando e problematizando a noção de cinema-verdade. Podemos mentir diante da câmera atuando os nossos próprios papéis? O que viram era verdadeiro ou não? ${ }^{75}$
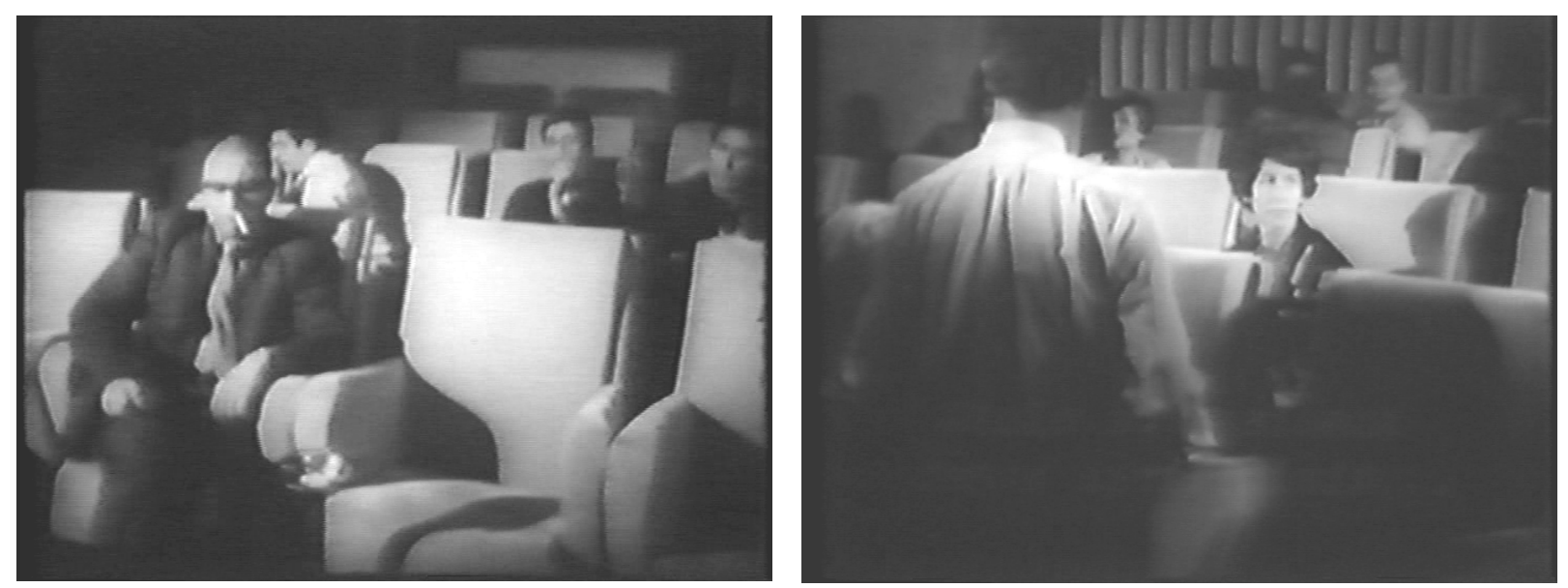

À luz dos nossos olhos de século XXI onde tanto a paisagem das cidades como a própria figura de homem urbano é impensável sem os aparelhos de mediação de imagens como celulares com câmeras, televisões, computadores, câmeras de vigilância públicas e privadas, hand-cams e uma equipe de reportagem de televisão a cada 100 metros nas ruas das grandes cidades, só para citar alguns dos dispositivos

\footnotetext{
${ }^{74}$ Cf. O roteiro de Crônica de um verão em publicação sobre o filme já citada anteriormente. p.125.

${ }^{75}$ Hoje em dia o procedimento de mostrar às personagens suas imagens é uma prática a que tanto os documentaristas como o público brasileiro já estão mais familiarizados. Cabra marcado para morrer, 1964-1984 e Boca do lixo, 1992, de Coutinho, À margem da imagem e As parteiras, 2004, de Evaldo Mocarzel, Nem gravata nem honra, 2001, de Marcelo Masagão, são bons exemplos da utilização desse dispositivo narrativo.
} 
que a sociedade contemporânea adotou como prótese e extensão de si mesma, essa questão pode parecer pueril e anacrônica. Porém, a reflexão da verdade da imagem e da imagem verdadeira se fazia legítima naqueles anos 60 , prenúncio da política da reflexidade, que estabelecia no interior da própria obra a desconstrução da transparência dos modelos narrativos clássicos, inaugurando uma narrativa que pensa e narra a si mesma.

Na cena final, Rouch e Morin conversam acerca do processo à luz e mágoas da opinião dos personagens/espectadores sobre o filme, tornando esse momento, no nosso entender, um dos mais fecundos do documentário. A preocupação com a questão da felicidade e do estilo de vida se dilui no confronto com as reações nem sempre amistosas dos espectadores, dando lugar ao questionamento da autenticidade da representação cinematográfica do outro e de si mesmo. Caminhando em ida e volta no Museu do Homem, lugar de trabalho de Rouch, as personagens-documentaristas contestam impressões e reações das personagensespectadores diante do filme. Esperavam um outro tipo de receptividade, talvez a adesão e empatia total aos "momentos de cinema-verdade" construídos diante da câmera, mas isso não aconteceu. Morin avalia que a reação foi recorrente de um espectador desassistido diante de uma nova forma de narrativa documental.

Esse filme, diferente do cinema habitual, nos reintroduz na vida. As pessoas estão diante do filme como vivem o seu dia-a-dia, quer dizer, elas não são guiadas, porque nós não guiamos os espectadores. Nós não dissemos a ele: esse é gentil, esse é mal, esse é simpático, esse é inteligente... Então diante dessas pessoas que eles bem poderiam encontrar na vida, eles ficam desamparados, eles 
sentem que são colocados à prova eles mesmos, eles se sentem interpelados e tentam recusar (...). E têm outros que se emocionam por isso (...) Ao início pensei que todos se emocionariam com esse filme e ver as pessoas de quem gosto muito (...) serem contestadas... isso me chateia. Eu achei que as pessoas iriam gostar das personagens que eu gostei.

Para além do "filme de amor"76 e ao espelhamento de suas próprias vidas na de outrem, o questionamento acerca do estatuto da representação - desde o interior dela mesma - emergiu com intensidade através da tela. Interessante, diz Morin, que as opiniões dividem-se em: ou bem as pessoas acham que as pessoas encenam demais ou são verdadeiras demais. Percepções que se chocam àquelas dos documentaristas: nós estávamos lá, dizem eles "nós vimos que não era mentira (a atuação de Marceline da qual já falamos), e se era mentira aquela era uma parte sua muito verdadeira". Talvez contaminado por essa experiência gerada pelo choque cultural dentro de sua própria sociedade e por exercitar um cinema de provocação e encontro, Rouch passaria a professar que o cinema verdade remete à verdade das imagens. Uma verdade impura e provocada pela presença do realizador-câmera.

O que eu disse diante deste microfone eu não diria se nós estivéssemos diante de um copo de cerveja. Simplesmente porque há um microfone. Há, então, aí um fenômeno muito estranho. E este fenômeno é uma espécie de catalisador que permite revelar, sem dúvida, uma parte fictícia de cada um de nós, mas que para mim é a faceta mais real do indivíduo ${ }^{77}$.

\footnotetext{
${ }^{76}$ Palavras de Rouch no diálogo referido.

77 Rouch em entrevista a ESNAULT, Philippe. Jean Rouch ou Les Aventures d'un nègre blanc. La Revue du Cinema - Image et Son. n. 249, Avril 1971, p. 72.
} 


\subsection{Sociabilidades documentais urbanas: o objetivo-orgânico e o imaginário-cristal na narração das cidades}

Em seus jogos de proximidade e distância Primárias e Crônica de um verão acabaram por gerar duas formas distintas de sociabilidade documental urbanas. Sociabilidade entendida, sempre é bom lembrar, como a estética cinematográfica engendrada nos inevitáveis encontros, negociações e partilhas entre o documentarista e o mundo sobre o qual fala. Sociabilidade documental, portanto, porque impõe ao documentarista gestar um pacto narrativo e "estar lá" "junto-com" as pessoas sobre as quais fala, em uma dinâmica inter-relacional desde onde gera a construção de um documento, testemunho etc., não importanto o quanto experimental seja essa inscrição nas imagens/sons.

Laços sociais que nos evocam possíveis formas de narrar a cidade e que no nascer desses estilos (direto e verdade) iriam estabelecer também o diálogo com dois regimes de imagens. Um mais voltado à ambição de um efeito de objetividade, à construção de uma estética do real a partir da observação dos acontecimentos, e o outro integrando o imaginário ao real para fazer emergir uma verdade possível e cotidiana a partir da interação com suas personagens.

No nosso entender, podemos problematizar uma certa origem da sociabilidade documental graças ao campo conceitual que se criou na tensão entre os estilos estabelecidos pelo Direto de Drew e sua trupe, com a preocupação de esfacelar sua presença de todas as maneiras possíveis, em contraponto ao Verdade de 
Rouch e Morin, que integrando-se ao fenômeno pesquisado como documentaristaspersonagens, afirmam a presença do processo cinematográfico e de seus dispositivos. Em sua análise acerca dessas tradições, André Parente propõe uma distinção entre o cinema norte-americano, que nomina como direto $^{78}$ e que, no seu entender, não se descola da reportagem e dos grandes acontecimentos e o cinema indireto de Rouch, Perrault e Cassavetes aberto ao improviso, à fabulação e à valorização dos pequenos acontecimentos. Essa distinção de direto/indireto remete-nos aos regimes orgânico e cristalino, respectivamente, tal como propõe Deleuze ${ }^{79}$ em sua reflexão acerca das "potências do falso" nas novas cinematografias inauguradas pelo direto (ainda Rouch, Cassavetes e Perrault).

Para Deleuze, no regime orgânico, sujeito e objeto são descritos como independentes. Não importa se o são realmente, mas sim que "cenários ou exteriores, o meio descrito seja posto como independente da descrição que a câmera dele faz e valha por uma realidade supostamente existente" 80 . Nesse sentido, real e imaginário apresentam-se como dois pólos opostos e dicotômicos e há, na concepção (documental) desse regime, uma percepção do real possuindo uma continuidade nas imagens audiovisuais. Uma "narração verídica que aspira ao verdadeiro" 81.

\footnotetext{
78 Como lembra Parente, o termo Cinema Direto, proposto por Mário Ruspoli, em 1963, se impôs rapidamente reagrupando diferentes tendências: free cinema da escola documentarista inglesa; candid eye do grupo de língua inglesa OFN (Office National du Film), do canadá; living-camera do grupo Drew associates; cinema do comportamento de Leacock; cinema verdade de Rouch e Morin; cinema vivido de M. Brault e Perrault. Para designar o estilo introduzido por Drew e Leacock, utilizaremos aqui os termos cinema observacional, proposto por Bill Nichols. Op.cit., cinema de observação, utilizado, entre outros pelos antropólogos David McDougall, Emille de Brigard e Colin Young (cf. FRANCE, Claudine (org). Pour une anthropologie visuelle....), op. cit.

79 DELEUZE, Gilles. A imagem-tempo. São Paulo: Brasiliense, 1990. p. 155-157. Para Deleuze, o regime orgânico, que opera através de cortes racionais e encadeamentos, tem sua pertença à imagemmovimento, assim como o regime cristalino atua desde o interior da imagem-tempo, campo da irracionalidade e da potência do falso.

${ }^{80}$ Idem, ibidem.

81 Op.cit., p.157.
} 
Porém, se a razão invade o regime orgânico a desestabilização infiltra-se no cristalino. Ali, segundo Deleuze, a descrição vale por seu objeto, que o substitui, criao e apaga-o a um só tempo. Ao contrário da divisão cartesiana do regime orgânicodireto, aqui real e imaginário atuam em relação de indiciossabilidade.

(...) num circuito em que o real e o imaginário, o atual e o virtual, correm um atrás do outro, trocam de papel e se tornam indiscerníveis. Aqui poderemos falar com precisão em imagemcristal: a coalescência de uma imagem atual e de sua imagem virtual, a indiscernibilidade das duas imagens distintas ${ }^{82}$.

Contaminados por essas perspectivas gostaríamos de propor que a sociabilidade distanciada impregna-se de organicidade, muitas vezes reforçando o mito da transparência e objetividade das imagens. Enquanto aquela, mais próxima e intercessora, se reflete no regime cristal, criando um espaço ao esfumaçamento das fronteiras entre real e imaginário, integrando-os como discurso possível e necessário à própria fabulação que é a escritura documental.

O cinema direto no Brasil, seus dispositivos técnicos e de interação, chegaram de forma lenta e fragmentada. Em que isso não pese, seus estilos foram digeridos de forma parcial já que o conceito de moderno vinculava-se a uma pedagogia cinemanovista de critica e cura do subdesenvolvimento nacional. No capítulo seguinte, veremos como essas formas de interação e sociabilidade instauram-se e são

${ }^{82}$ Op.cit., p.156. 
reprocessadas ao longo do tempo, dos anos 60 até os dias de hoje, nas narrativas documentais urbanas brasileiras. 


\section{DISPOSITIVOS DE INTERAÇÃO}

No capítulo anterior vimos que foi no nascer das tradições modernas do documentário que se configuraram dispositivos de interação no encontro entre o documentarista e o mundo apontando às estéticas do distanciamento e da intimidade, caras à sociabilidade documental. Dispositivos de interação que se deram graças ao desenvolvimento de dispositivos técnicos configurados pelas câmeras mais leves $(16 \mathrm{~mm})$ e, sobretudo, pelo som sincronizado engendrando diferentes formas de presença do realizador e da captação da imagem e da voz do outro.

Formas de encontro e de partilha (narrativa, urbana, cultural, etc.) investindo em novas dramaturgias documentais. Desde aí, sugerimos que no agenciamento desses dispositivos de interação possibilitados pela revolução tecnológica desdobram-se atualizações estético-conceituais das tradições modernas no documentário brasileiro contemporâneo.

Do cinema verdade de Rouch e Morin fica a herança do documentarista como personagem, da entrevista intercessora, do clima confessional, dos debates à mesa, do investimento a uma dramaturgia do imaginário e da fabulação regidos pela fala e ainda, como veremos adiante, dos desdobramentos da antropologia 
compartilhada rouchiana apontando, na desestabilização da autoridade narrativa, a certa gênese da entrega da câmera à mão das personagens.

Já a tradição norte-americana deixa como legado a afirmação da presença do realizador-câmera na construção da cena, desenvolvendo a partir da estética de captação, que se contamina pelo ritmo e cadência dos movimentos de suas personagens, uma dramaturgia dos gestos e da fabulação regida pela ação e gestualidade. A um só tempo documentarista e personagens se reinventam através de suas performances no momento da filmagem e por causa dela. É, sem dúvida, a câmera construindo um olhar da experiência-corpo, aderindo ao movimento do mundo captado.

Contudo, dando continuidade ao projeto jornalístico que lhe originou, o cinema direto perpetua-se também em narrativas que apostam nos mitos da transparência, da objetividade e da evidência da imagem, conferindo-lhes um valor irrefutável. Perspectiva que nos reenvia aos conceitos trabalhados anteriormente do objetivo-orgânico e do imaginário-cristal na narração das cidades. Porém, enquanto o objetivo-orgânico mantém o espaço da subjetividade mais domesticado e sob controle do olhar da câmera, o imaginário cristal a eleva ao estatuto de imagem e investe no jogo da intersubjetividade apostando cenicamente na relação entre documentarista e documentados.

Em seus regimes narrativos, entretanto, ambas as tradições trazem um dado importante para olharmos as impuras produções documentais recentes à medida que procuram atravessar a imagem do outro em busca de sua singularidade e de 
transmutar em narrativa audiovisual a vivência cotidiana do homem urbano do seu tempo.

Indo em direção ao microevento, situação já esboçada por Flaherty, apesar da boa dose de romantismo, em Nanook of the north e mesmo por Rouch nas etnoficções em terras africanas, as tradições modernas em seus dispositivos técnicos e de interação dão passos à frente na superação do exotismo da imagem do outro. São tradições que a um só tempo constroem e integram o processo do próprio tempo moderno contemporâneo, enquanto propõem formas de narrá-lo, de testemunhá-lo e de colocarem suas personagens ao centro desse testemunho.

\subsection{A integração dos dispostivos de interação no Brasil}

David Neves cartografa em $A$ descoberta da espontaneidade o encontro dos cineastas brasileiros com as tradições do cinema verdade e do cinema direto que, segundo o cineasta, foi se dando pouco a pouco. A exibição de Crônica de um verão, numa semana oficial do cinema francês promovida pela Unifrance Film, em 1962 e “o nome dos cineastas americanos Robert Drew, Richard Leacock e os irmãos Albert e David Maysles que trabalhavam cobertos por uma leve cortina de discrição"1, esboçaram os primeiros contatos da turma brasileira com os dispositivos de interação nascidos lá fora, sobretudo a entrevista, o flerte com a política da reflexividade na utilização dos dispositivos audiovisuais como estratégia de integração e de

\footnotetext{
1 Cf. NEVES, David. A descoberta da espontaneidade. In: Dossiê David Neves. Disponível em: www.contracampo.com.br
} 
aproximação da personagem, bem como o efeito de intimidade gerado, cada qual a seu modo, nas duas tradições.

Porém, os contatos dos brasileiros com essas estéticas nascentes eram precários, à medida que os filmes dos norte-americanos só chegaram ao Brasil recentemente, em pleno século XXI e Crônica de um verão, como conta Neves, teve essa única exibição promovida pela instituição francesa. Contudo, apesar de precário, esse foi um encontro marcante para a jovem geração de cineastas vinculados ao cinema novo e que buscava promover rupturas com os modelos educacionais anteriores, sobretudo os desenvolvidos pelo INCE (Instituto Nacional do Cinema Educativo, vinculado ao Ministério da Educação), que dominava a cena da produção documental do período.

Nesse mesmo ano de 1962, a Unesco e a Divisão de Difusão Cultural do Ministério das Relações Exteriores organizam, no Rio de Janeiro, um Seminário de Cinema, com o cineasta sueco Ame Sucksdorff, que traz na bagagem dois gravadores Nagras introduzindo, na prática, algumas das possibilidades dos novos dispositivos técnicos e estéticos que propunham os estilos do direto.

Joaquim Pedro Salgado, que havia realizado estágios na Inglaterra, Europa e nos Estados Unidos, onde conviveu pessoalmente com os irmãos Maysles, mestres do cinema direto, volta ao Brasil e realiza Garrincha, alegria do povo, 1962. Contudo, as precárias e pesadas condições técnicas impossibilitam a aplicação de seu aprendizado.

Apesar das deficientes técnicas na obtenção de um som direto perfeito, Maioria absoluta, em 1963, de Leon Hirzsman, dá um passo adiante nessa direção em 
sua temática do analfabetismo cotejada a outros males sociais como a doença e a miséria, integrando com mais propriedade a entrevista e capturando em suas imagens certo espírito urbano de seu tempo. Integração Racial, de 1963, do cinemanovista Paulo César Sarraceni, avança um pouco mais em termos de estilo. Neves conta que Sarraceni

participou, em Sestri Levante, dos encontros e projeções com franceses e canadenses que discutiam as estilísticas do direto. E trouxe certas teorias às quais adaptou o material disponível. A obrigação de intimidade era uma delas, apesar da dificuldade imposta pelo peso, porte e ruído de uma câmera Arriflex $35 \mathrm{~mm}$. Usando algumas objetivas de focal curta $(18,5 \mathrm{~mm}$ e $35 \mathrm{~mm})$ conseguiu-se alguma intimidade com o objeto, sobretudo nos momentos onde o som direto não era absolutamente rigoroso ${ }^{2}$.

Uma outra experiência marcante no seminal cinema direto brasileiro ocorreu por iniciativa do fotógrafo e produtor Thomas Farkas. De olho nas televisões estrangeiras, o fotógrafo produz uma série de três documentários urbanos rodados em São Paulo e Rio de Janeiro onde buscava retratar certa cotidianidade das grandes cidades em um Brasil subdesenvolvido e liderado pelo golpe militar. Nossa escola de samba, de Manuel Horácio Gimenez, Viramundo, de Geraldo Sarno e Subterrâneos do futebol, de Maurice Capovilla, todos produzidos em 1964.

Apesar das novas propostas de leveza, mobilidade, improviso e todo um repertório de rupturas éticas e estéticas em relação às tradições anteriores, que propunham o direto norte-americano e o verdade francês encontrarem eco no

\footnotetext{
2 Idem, ibidem. Grifo nosso.
} 
emergente cinema novo de Glauber Rocha, a assimilação ao campo documental não se deu da mesma maneira. Em parte, como sabemos, por uma defasagem técnica ${ }^{3}$, já que nossos recursos de câmera e captação de som eram ainda pesados e modestos, não permitindo a liberdade e efeito de intimidade alcançado pelos estilos nascentes, mas também por uma outra cultura urbana que motivava a jovem classe cinematográfica, mais pautada nas preocupações político-sociais à sua volta, mas, sobretudo, por um lugar distanciado e privilegiado no qual se colocava a classe cinematográfica dificultando ainda mais o efeito de proximidade e inter-relação.

O subdesenvolvimento emerge como temática recorrente nos documentários da época desenhando a cidade como um cenário, quase sempre hostil, onde os fenômenos acontecem e o cineasta, uma entidade intelectual capaz de diagnosticar e apontar os males sociais. A partir de 1964, quando o mundo vivia a fase áurea das técnicas do cinema direto, os realizadores brasileiros se defrontam com os constrangimentos de viver em um Estado ditatorial repressivo e constantemente vigilante, sobretudo nas ruas das grandes cidades.

Fatos que acabam por reforçar um modelo híbrido que a um só tempo dialogava estilisticamente com o documentário clássico, na fatura da voz over, incorporando também, dentro dos limites técnicos e das concepções pessoais, as inovações propostas pelas novas formas de narrar. Da alma do documentarismo clássico esses filmes herdam a autoridade narrativa com fins pedagógicos operando em horizonte ideológico e de uma responsabilidade intelectual que muitos cineastas, partidários de uma filosofia antiditadura, se atribuem.

${ }^{3}$ Idem, ibidem 
Uma militância educativa, onde o realizador onipresente, representado pelo narrador off e reforçado por sua constante ausência em quadro, propõe teorias e análises aos males sociais. Como nos documentários antecessores ao som sincronizado, em muitos momentos as imagens servem para ilustrar e reforçar as teorias expostas pela locução em voz over. Nesse mesmo sentido atuam as entrevistas reduzidas ao lugar de dispositivo auxiliar ao texto dito pelo locutor ${ }^{4}$, demarcando de antemão o lugar do entrevistado e não lhe dando margens para cumprir um outro papel além daquele que lhe foi determinado pelo documentarista (o analfabeto, o popular classe média, o empresário, o retirante bem ou mal sucedido na cidade, etc.), limitando o jogo da interação entre o cineasta e seus atores sociais. Jean Claude Bernardet observa que grande parte dos filmes desse período está dominada pelo modelo sociológico que tipifica o outro em esquemas generalizantes, destituindo-lhe a subjetividade, a singularização e a ambigüidade inerentes à experiência humana e, sobretudo, às personagens modernas 5 .

Contudo, apesar dessas opções narrativas que reduzem de forma decisiva o charme e a contemporaneidade das obras, elas também têm riquezas que eclodem, sobretudo, nos interstícios das "vozes do saber" ou para além delas. Cláudia Mesquita aponta que na trilogia urbana de Farkas há uma diversidade estética e conceitual que relativiza drasticamente o conceito de modelo sociológico proposto por Bernadet. A autora refere-se, prioritariamente, à Nossa escola de samba, aonde uma locução subjetiva da personagem conduz a trama, vinculando a obra em chave

\footnotetext{
${ }^{4}$ Jean Claude Bernardet em Cineastas e imagens do povo (São Paulo: Companhia das letras, 2003. p. 25), em análise do filme Viramundo, propõe que o empresário entrevistado cumpre a função de locutor auxiliar ao narrador em voice over.

${ }^{5}$ Op.cit., p. $11-18$.
} 
moderna. Nesse sentido destaca ainda no mesmo filme o corpo a corpo que Alberto Salvá e Thomas Farkas estabelecem na captação de imagens do ensaio da escola de samba na favela ${ }^{6}$.

Acreditamos, entretanto, que Subterrâneos do futebol, ainda assim, vincula-se, como os outros filmes do período, a certa ética educacional da dramática do subdesenvolvimento engessando, sob essa pedagogia, até mesmo as possíveis riquezas no jogo da interação entre documentaristas e documentados. Talvez por demarcar a uns e outros lugares muito estanques e sem conexões possíveis. Mas, também concordamos inteiramente com a pesquisadora no sentido de que mesmo que a maior parte dessas produções ancore-se no redutor "modelo sociológico" há em todas elas toda uma imagística da cultura urbana da época propondo um rico repertório comportamental da vida nas cidades brasileiras na década de 60 , bem como uma originalidade no estilo direto e observacional de captação e montagem que transborda para além das amarras do modelo clássico, com o qual também dialogam.

As seqüências religiosas, antecipando com o método de montagem o debate contemporâneo das ciências sociais acerca das aproximações entre as religiões evangélicas e afro-brasileiras ${ }^{7}$, bem como a peregrinação pelas ruas de São Paulo em Viramundo, de Geraldo Sarno; ou ainda as incursões de estética dionisíaca nos ensaios de carnaval em Nossa escola de samba, bem como o inigualável retrato de Copacabana e de toda uma juventude já atravessada pela cultura pop emergente da televisão e da jovem guarda (ainda que apresentada em chave de "alienação da classe média") no

\footnotetext{
${ }^{6}$ MESQUITA, Cláudia. Festival é Tudo Verdade. In: Seminário Internacional de documentários, 2002, São Paulo.

7 Idem, ibidem.
} 
especialíssimo Opinião pública, 1966, de Arnaldo Jabor, que privilegia o estilo observacional e uma sociabilidade distanciada são belos exemplos dessa primeira idade do direto brasileiro.

Momento em que o documentário ficou a meio caminho em termos de estilo e atado, no nosso entender, a um conservadorismo às avessas, construindo ao cineasta uma autoridade que o impedia de se pensar a si mesmo enquanto observava e criticava os seus iguais. Postura que em muitos filmes do período acaba por inscrever um efeito de sociabilidade documental estéril e domesticado em prol do rígido esquema narrativo imposto à obra.

As mudanças formais viriam, porém, por vias inesperadas em uma das mais extraordinárias experiências do documentário brasileiro dentro da indústria. Vários cineastas egressos da ficção produziram verdadeiras obras primas do documentário na maior rede de comunicação do país. Em 1970, a Rede Globo, uma das principais responsáveis pela promoção e manutenção do golpe de Estado, encomenda a Carlos Augusto Oliveira (Blimp Filmes) um programa para homenagear o aniversário de São Paulo. Como lembra Beth Formaggini ${ }^{8}$, São Paulo, terra do amor, produzido em 35 $\mathrm{mm}$, iniciava com uma tomada da metrópole filmada com uma grande angular olhode-peixe prenunciando que "a linguagem do cinema entrava pela primeira vez na televisão brasileira" 9 .

Essa seria a semente do Globo Repórter, que entre as décadas de 70 e 80 reuniu o maior número de documentaristas produzindo trabalhos da melhor qualidade. Em 1973 o veterano Paulo Gil Soares, que havia participado da já citada Caravana

8 CF. FORMAGGINI, Beth. Cinema na TV: Globo Shell especial e Globo Repórter (1971-1979). In: Festival É tudo verdade, 2002, São Paulo.Catalogo. São Paulo, 2002.

${ }^{9}$ Idem, ibidem. 
Farkas, assume a coordenação do núcleo do Rio de Janeiro. Neste período, integramse ao programa nomes caros à cinematografia nacional, entre eles Eduardo Coutinho, Eduardo Escorel, Hermano Penna, João Batista de Andrade, Geraldo Sarno, Walter Lima Jr, Osvaldo Caldeira, Silvio Back, Jorge Bodanski, Alberto Salvá, Maurice Capovilla, Leon Hirszman, como diretores e mais Dib Lufti e Adrian Cooper à câmera, entre outros. Para a maior parte deles este também foi o espaço de suas estréias como documentaristas.

Os filmes eram realizados em película $16 \mathrm{~mm}$ reversível e o tempo do processo de realização incluía pesquisa, filmagem e montagem, tudo dentro de um ritmo alheio à dinâmica das reportagens televisivas.

Até o final dos anos 70 o Globo Repórter era uma espécie de nicho dentro do jornalismo da Globo - sujo, mais autônomo, mais lento. Mais aberto à controvérsia e à experimentação, menos obcecado pelo problema do Ibope, da concorrência. ${ }^{10}$.

As memórias do cineasta delineiam, paradoxalmente a época de interditos e repressões do regime militar, um momento de liberdade onde o Globo Repórter foi cenário de experimentações de forma e linguagem. Muitas dessas rupturas foram capitaneadas por João Batista de Andrade, que em 1974 foi convidado para criar em São Paulo a divisão de reportagens especiais.

Antes de sua entrada na Globo, Batista já vinha promovendo algumas inovações em seus documentários mais voltados a um cinema de intervenção, aonde dialogando com o espírito provocativo atuava em frente às câmeras como

${ }^{10}$ COUTINHO, Eduardo. A astúcia. In: NOVAES, Adauto (org.). Rede imaginária. São Paulo: Secretaria Municipal de Cultura/Companhia das Letras, 1991. p.281. 
personagem de si mesmo, em franco diálogo e atualização das propostas apresentadas em Crônica de um verão. Em documentários como Liberdade de imprensa, 1971 e Migrantes, 1972, desenvolveu um método de trabalho que Bernardet chamou de dramaturgia da intervenção: uma "prática de gerar a realidade que filmava" promovendo eventos com a presença da câmera e por causa dela ${ }^{11}$. Nesses filmes, rodados sobretudo nas ruas da capital paulista, o realizador já minimizava a função do narrador em voz over, agora dirigido mais a contextualizar e informar do que tecer teses eloqüentes sobre o assunto. Eixo que o coloca em sintonia com as tradições modernas do documentário, bem como aponta uma direção diferente daquela que estava sendo perseguida nos filmes de seus contemporâneos.

Assim, quando integra a equipe do Globo Repórter Batista leva esse espírito de mudanças formais na bagagem, direcionando, diferentemente de seus colegas cariocas, o núcleo paulista a temáticas mais urbanas. Coutinho lembra que a grande discussão entre os cineastas do Globo Repórter era a de "se livrar do narrador, identificado com a voz do dono" e, nesse sentido, a contribuição de Batista foi fundamental, sobretudo em Caso Norte, 1977 e Wilsinho Galiléia, $1981^{12}$.

Nessas reportagens, João Batista mistura atores e pessoas comuns em busca de uma reconstituição dos eventos narrados. Operando em registro misto e impuro intercala encenações com depoimentos "reais", criando uma espécie de docudramareflexivo, onde ele mesmo entra em cena, como personagem de si mesmo, para dirigir as atuações.

\footnotetext{
${ }^{11}$ BERNARDET, Jean-Claude. Op.cit. p.69-84.

${ }^{12}$ Conversa entre Eduardo Coutinho e João Salles no Brasil Documenta. Rio de Janeiro, 2001. FITA DE VÍDEO.
} 
Um outro filme produzido no Globo Repórter e que se aproxima do estatuto de obra prima do documentário urbano do período é Retrato de Classe, 1977, de Gregório Bacic, que também promove várias mudanças estilísticas no interior do programa, influenciando as produções posteriores. Realizado no mesmo ano que Caso Norte, merece um olhar mais demorado em suas estratégias formais pelo tanto que avança no diálogo com as tradições documentais modernas, bem como pelos diversificados dispositivos de interação engendrados pelo documentarista em sua aproximação com as personagens (e entre elas).

Assinando o roteiro e a edição, o jornalista Fernando Pacheco Jordão, diretor do núcleo paulista do Globo Repórter à época, vinha de uma estada na $B B C$ de Londres empolgado em desenvolver filmes que apresentassem a biografia de pessoas desconhecidas ${ }^{13}$ e aposta na idéia de Bacic. $\mathrm{O}$ documentário parte de uma foto da turma primária da escola particular Carminda Ribeiro, em 1955, localizada em um bairro paulistano.

Eu fui privilegiado. Tive dez meses para fazer esse trabalho. Optamos por uma foto de escola que tinha meninos e meninas, num bairro de classe média que passava por um processo de transformação ${ }^{14}$,

conta Gregório Bacic.

Vinte e dois anos depois restavam da escola demolida suas ruínas. O diretor, que não possuía o menor vínculo com nenhuma das personagens estampadas na

\footnotetext{
${ }^{13}$ CF. o artigo de João Salles "Retrato de classe" em Ilha deserta: Filmes. São Paulo, Publifolha, 2003.; Felipe Bragança, site contracampo (www.contracampo.com.br) e a matéria da Revista Veja, de 21 de dezembro de 1977, de Guilherme Cunha Pinto.

14 Depoimento de Gregório Bacic a Beth Formaggini, Catálogo do Festival Internacional de Documentários É tudo verdade, 2002.
} 
foto, convoca-se à missão de reencontrar cada uma delas para saber o que era feito de suas vidas. Ao final da pesquisa, com quase todas as pessoas localizadas, ele vai em busca daquela que traria todo o diferencial ao documentário: a professora Eunice, eleita condutora narrativa do filme, grande parte do tempo em off, dispensando, assim, os locutores oficiais do programa.

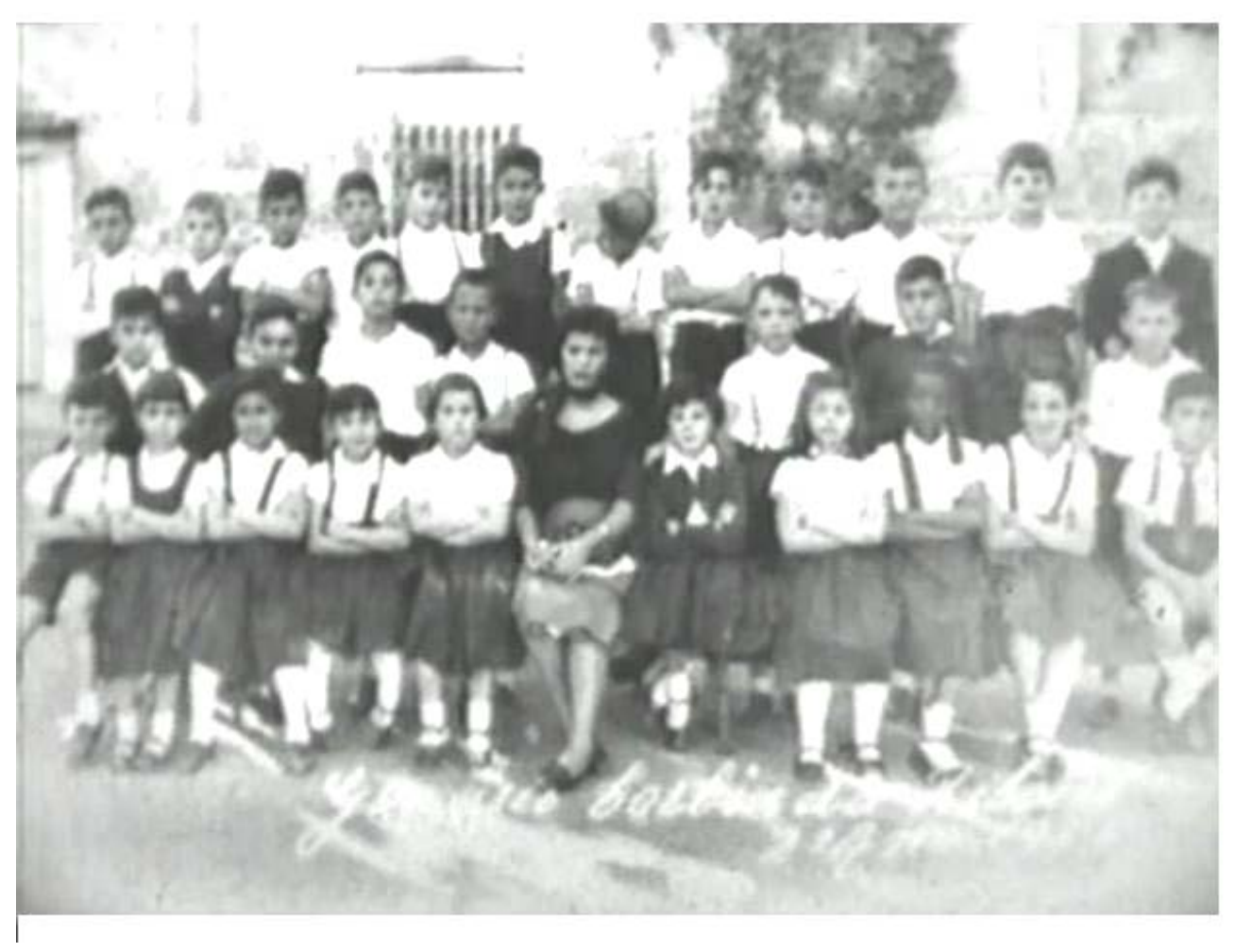

Retrato de Classe vai ainda mais adiante em suas opções narrativas e promove depois de todos esses anos o encontro para o filme entre dona Eunice e seus pupilos em uma festa na casa de um deles. Na ocasião ela é desafiada a reconhecer um ou outro, comove-se, chora, recebe flores, carinhos e declarações de apreço. A câmera observacional registra a surpresa do reencontro, as danças, risadas e a fala de Dona 
Eunice que, provocada por um aluno - “o que você esperava de nós?" -, expõe suas boas expectativas.

A montagem rompe a cronologia de todos esses acontecimentos, apresentando-os sucessivamente nas seqüências iniciais transformando, assim, os próprios dispositivos de aproximação em acontecimento narrativo. A mobilização dos olhares e das lembranças de um em relação ao outro pelo retrato da classe, o uso recorrente do off sem mostrar a imagem daquele que fala, a gravação do áudio da conversa que o documentarista teve com Eunice e que leva a um e outro como forma de provocar reações e transformar o momento da escuta em cena, o registro em ambientes pessoais e privados dos ex-alunos, a festa do reencontro. Apresentadas as armas estratégicas ao espectador, a edição passará a combiná-las fazendo emergir uma sofisticada trama do imaginário urbano e da cultura comportamental da época.

É a foto comentada em voz off, sobretudo pela professora, que pontuará o documentário do início ao fim. Vinculando-se com o que poderíamos, ainda uma vez, nominar como a dramaturgia do imaginário e da fabulação, dona Eunice reconstrói a partir de suas lembranças um perfil de cada criança e arrisca o palpite do seu destino adulto. Momento em que as personagens entram em cena, observadas em suas casas e em seus locais de trabalho. Além de mostrarem-se atuando em seu cotidiano, conversam com o documentarista sobre suas concepções de mundo confrontando, assim, sua vida atual com as evocações e previsões da mestre.

Bacic elabora suas personagens guiadas pelo eixo proposto pela percepção da professora: o perfil do aluno em classe projetado à sua vida futura e profissional. Linha de onde emerge a tensão dos tradicionais valores sociais e culturais que, 
naquele final dos anos 70, estavam mais permeáveis a dúvidas e incertezas até mesmo no interior da conservadora classe média que os sustentava. Há uma militância de classe (cultural/intelectual), quase cruel, no olhar do diretor. O que você fez da sua vida em relação ao futuro que lhe prevê Dona Eunice? Pergunta o filme já engendrando respostas a partir da prova cabal, do testemunho tecido desde o interior da vida de cada um deles.

Um a um ora traem ora confirmam as projeções de dona Eunice na evolução de suas trajetórias. O primeiro e o último da turma, que se tornaram vendedores; a aluna negra que sempre esteve em condição desigual na classe cumpre a profecia social e torna-se empregada doméstica; a menina inteligente com futuro promissor que se dedica com alegria à vida do lar.

É justamente nesse confronto de previsões e atualizações do destino da vida média brasileira que Bacic tenta construir seu Retrato de classe, quase sempre precário aos olhos de uma personagem-vidente, ela mesma ressentida com seu destino. “Já me disseram que eu sou uma mulher realizada, que eu nada mais deveria querer ter na vida além daquilo que eu já tenho. Criar os meus seis filhos e estar comandando a minha casa. Mas, no meu íntimo, eu me sinto frustrada. Eu não dei nada de mim para a sociedade. Eu não fui ninguém lá fora".

Depoimento que encontra coro no elenco feminino do documentário aonde as mulheres estão presas ao lar, seguindo a filosofia doméstica de bem servir os filhos e o marido. Mesmo a infeliz e obediente Aurora, que cultivou o sonho de ser atriz, mas teve uma vida "castrada, controlada e dominada", volta para casa antes das dez e meia da noite, pois "fica feio para uma mulher estar na rua até tarde", rezava a 
tradição dos seus pais naquele prenúncio dos anos 80 . “No dia a dia a minha mãe ensinava a cozinha, a roupa, o colarinho (...) prendas domésticas para uma futura esposa", conta ela que apesar de nunca ter esquecido o desejo da ribalta formou-se em pedagogia e foi trabalhar com carnês de aposentadoria. Luiza que “deve ter sido uma boa mãe ou então fez curso universitário, pois tinha grandes possibilidades para isso devido sua inteligência", conforme a visionária Eunice, afirma que nasceu para ser mãe e faz um curso de artes que lhe ocupa muito tempo. Solange, "de grande capacidade para aprender tudo que eu lhe ensinava", também se dedica com alegria ao lar e aperfeiçoa sua opção de vida emendando um curso no outro. Decoração, paisagismo, bolos artísticos, etiqueta, culinária e o de arranjo de Natal, que gostou muito, mas lamenta "é usado muito pouco, porque é uma vez só por ano".

Esses questionamentos acerca dos valores ligando o gênero e as opções sociais de cada um, serão reveladores da cultura urbana de sua época. Agenciados na montagem ou colocados em cena pelas econômicas e pontuais perguntas de Bacic, o documentário irá operar em chave provocativa nas suas intervenções e articulações narrativas. A apresentação do ex-aluno José Roberto Encerra é um belo exemplo.

Eunice está na festa, mais de vinte anos depois, lenço verde no pescoço, loira, roupa justa de veludo castanho, bolsa da mesma cor, um buquê de flores nos braços, ao centro de uma roda que os alunos fizeram em volta dela. Alguns estão mais próximos e ela parece tão jovem quanto eles. Tenta reconhecer um e outro, os homens, descontraídos, falam mais do que as mulheres das quais quase não se ouve a voz. Um deles aponta as pessoas que ela tenta reconhecer. Alguém fala: “José Roberto Encerra!". Ela olha mais atentamente na direção indicada. Fica em silêncio. 
Corta para plano geral da foto. A zoom se aproxima lentamente de um menino na extremidade esquerda do quadro e o off de Eunice diz "José Roberto Encerra... foi meu aluno no primeiro ano de 1955 até $1957 . . . "$.

Já vemos o aluno agora adulto, de gravata, falando ao telefone, em seu ambiente de trabalho. O off permanece e a mestre nos diz que ele era um menino de grande potencial, embora sofresse grande ascendência da mãe. E profetiza “Eu acho que se ele conseguiu libertar-se um pouco dos pais pode ter tido algum sucesso na carreira que escolheu ou, quem sabe, tenha continuado na mesma, fazendo aquilo que os pais sempre desejaram". Estava assinada a sentença de José Roberto, que se preparando para jogar futebol confessa ao documentarista o sonho de ter sido jogador profissional, o convite para integrar uma equipe na França e a proibição do pai. “E foi a partir daí que eu fui trabalhar com ele na indústria e estou com ele até hoje". O diretor ainda insiste (quase não ouvimos sua voz). Você gostaria de ter ido à França, de ter corrido esse risco? Gostaria sim, diz Encerra, já levantando pra jogar futebol.

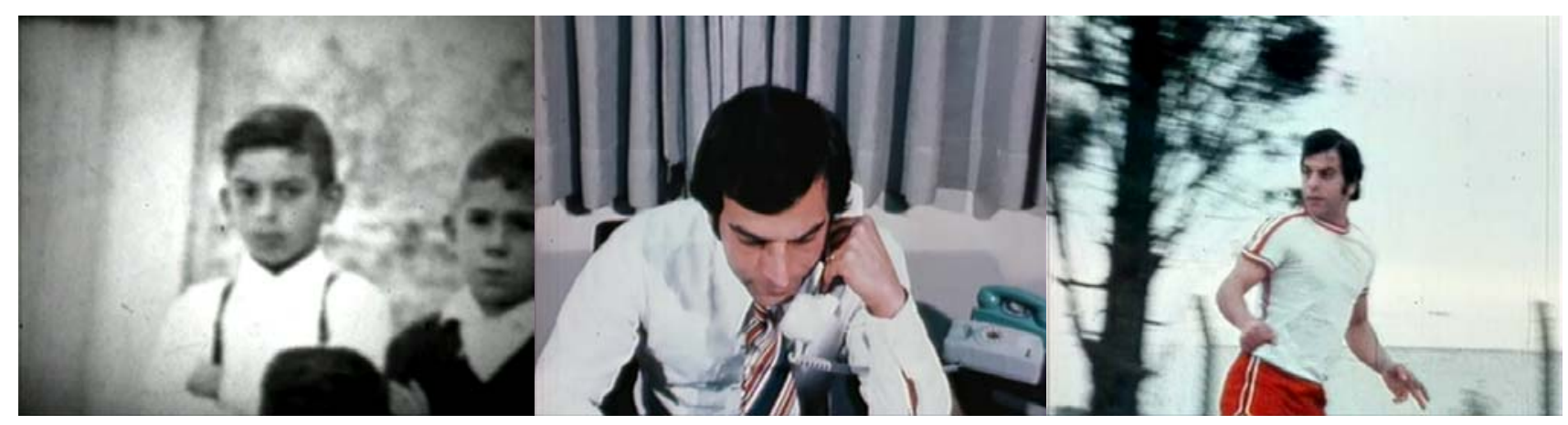

Na seqüência seguinte estamos junto dele e da esposa, grávida, arrumando as roupas na cômoda do quarto do nenê que está prestes a nascer. Ela mostra o único 
sapatinho cor de rosa que comprou. Ele não gosta. Não quer uma menina, gostaria que seu filho fosse menino. Pra mim tanto faz, diz a esposa, nascendo com saúde. Ele insiste. Quer um menino como primeiro filho. Ela diz que o homem tem preferência por menino porque acha que vai trabalhar com o pai, vai dar continuidade à indústria. Ele concorda e olhando para a esposa justifica: “A razão de eu querer um menino antes, você sabe..., lá é uma indústria de família, então precisa haver uma seqüência, uma continuidade nisso!".

Nós, espectadores, estamos perplexos com a pontual previsão de Dona Eunice; José Roberto além de não conseguir perseguir o seu sonho por obediência ao pai, repetirá o erro com seu próprio filho, que talvez seja menina. Astutamente corta para a cena de José Roberto jogando futebol e o conflito é articulado pelo off da esposa que novamente evoca o desejo abortado por uma imposição paterna: “Eu acho o seguinte: você já pensou na possibilidade de seu filho não querer ser industrial? A gente não pode de antemão escolher a profissão do filho, o que o filho vai ser!" conclui a mulher sobre as imagens do frustrado jogador.

Eis aí um dos trunfos narrativos do documentário de Bacic e Jordão: deixar emergir o retrato da classe média brasileira a um só tempo reafirmado e fragilizado em suas certezas, capturado desde o interior das vidas íntimas de seus personagens. Para conversar com os alunos de dona Eunice, Bacic faz um filme de visitas às casas e realiza ainda um outro retrato alcançado por um efeito de intimidade entre o documentarista e os documentados.

Efeito de intimidade já ensaiado com mais timidez em obras anteriores como Maioria absoluta, Integração racial e Opinião pública que também adentraram a vida 
privada de suas personagens, mas que aqui atinge uma maturidade formal. Bacic alterna momentos de pura observação com entrevistas reafirmando que a sensibilidade na maneira de filmar e agenciar a montagem foi tão fundamental quanto a feliz idéia no sucesso do documentário.

Nesse sentido, articula, em muitas seqüências, momentos confessionais de suas personagens. Tanto aqueles da professora que corajosamente confia ao documentarista suas reminiscências, quanto dos ex-alunos que expõem seus anseios e frustrações. Confissões à câmera, ao diretor, ao público da Rede Globo e a elas mesmas onde acabam transpirando seus valores e conceitos sobre o mundo. Da mesma maneira, a opção do documentário de se passar a maior parte do tempo no interior das casas (de Aurora, de Luisa, de Solange, de José Roberto, da festa) e a interação alcançada por Bacic com os entrevistados, antecipam um estilo que seria retomado com mais sistematização a partir dos anos 90 nas narrativas urbanas. Como, por exemplo, nos filmes de "conversa" de Coutinho Santo Forte, Babilônia 2000, Edifício Master, que ao privilegiar a casa como lugar do encontro documental, intensifica o efeito de proximidade e inter-relação do documentarista com sua personagem.

Inspirado nas rupturas propostas por Batista e Bacic, Coutinho realiza Teodorico, o imperador do sertão, 1978 e, da mesma forma, faz de sua personagem a principal condutora da trama amadurecendo o estilo de interação e entrevistas informais que viriam a lhe consagrar, bem como eliminando as narrações dos apresentadores da televisão. É também a partir de sua experiência no programa que ao deixar a Globo retoma o projeto inacabado de Cabra marcado para morrer, 1964-1984, e realiza o documentário considerado um dos marcos do cinema moderno brasileiro. 
Maurice Capovilla ressalta ainda que, ao contrário dos programas jornalísticos atuais que seguem rigorosamente um mesmo padrão, a marca do Globo Repórter era a diversidade imprimida pela personalidade narrativa de cada realizador. Característica que estimulava a eclosão de novos formatos e de uma competição saudável onde o norte das reportagens documentais era mais a preocupação em nutrir dúvidas e perguntas durante o processo de realização do filme do que reportar uma verdade acabada como faz o telejornalismo. Não havia ainda, lembra o diretor, o peso do padrão estético televisual que a um só tempo constrói a identidade e achata as possíveis diferenças. "Cada programa era um programa novo, cada filme era um filme único"15.

Na passagem para os anos 80 começam os problemas com a censura e filmes como A greve de março, 1979, de Renato Tapajós e Wilsinho Galiléia, 1981, de João Batista de Andrade tiveram suas exibições proibidas pelo censor federal. Em 1982 o programa é interrompido e volta em 1983 não mais em filme reversível, mas vídeo UMATIC ${ }^{16}$. Com a incorporação do videotape em detrimento do filme, instala-se uma maior visibilidade no processo de realização dos trabalhos e, consequentemente, um maior controle por parte da direção da emissora. As censuras, como lembra Coutinho, para além de focarem o conteúdo, estavam preocupadas no controle da forma. A manipulação do tempo, do espaço, do som, bem como de suas diferentes relações possibilitadas por opções de captação e montagem eram vigiadas e submetidas a restrições no sentido de uma maior padronização do produto final.

\footnotetext{
${ }^{15}$ Debate realizado em São Paulo por Ocasião do $7^{\circ}$ Festival Internacional de Documentários É tudo verdade, 2002.

${ }^{16}$ Informações retiradas do artigo já referido de Beth Formaggini.
} 
Portanto, quando em 1986 Jorge Pontual implanta no Globo Repórter o modelo de reportagem baseado na série norte-americana 60 Minutes, ancorado no repórter-herói afastando-se definitivamente do estilo documental, apenas consagra o final de um diálogo que já havia minguado.

Mas os anos 80 trariam também o prenúncio de uma mudança que afetaria irreversivelmente o estado do mundo e da cultura ocidental com a expansão das tecnologias do vídeo. Nesse contexto um outro fenômeno se instaura no cenário audiovisual do país: as produções independentes, que trazem uma enorme contribuição à renovação nas programações televisivas, bem como ao documentário brasileiro. Refletindo acerca da experiência do vídeo no Brasil, Arlindo Machado observa que ele emerge das mãos de uma geração que havia sido educada pela televisão e era ela que visava em suas produções.

Para as gerações que atingiram a maioridade nos anos 80, a televisão, com sua linguagem fragmentária, com seu ritmo veloz e com suas imagens em metamorfose, era o referencial mais notário ${ }^{17}$.

De uma certa maneira, os videomakers atuam no contra-fluxo dos experimentais superoitistas da década de 70 que como observa Rubens Machado Jr. ${ }^{18}$, "foi o pólo mais vivo de negação do que se fazia na tv, a sua antípoda viceral, destacando com isso sua especificidade política". Na geração do vídeo, ao contrário,

\footnotetext{
${ }_{17}$ Cf. MACHADO, Arlindo. Máquina e imaginário. São Paulo: EDUSP, 1993. p.293 e, do mesmo autor, A arte do vídeo. São Paulo: Brasiliense, 1984.

18 MACHADO Jr., Rubens. A polis ironizada: sobre a dimensão política do experimentalismo superoitista. In: CARDENUTO Filho, Reinaldo (org.). Golpe de 64: amarga memória, catálogo. São Paulo: Centro Cultural São Paulo, pp. 24-27.
} 
mesmo aqueles mais radicais que investiram em experiências "piratas", ou vinculados aos movimentos sociais (vídeo popular) operando em chave contestatória ao monopólio das comunicações, buscavam propor formas diferenciadas de produção, enfocando a riqueza e diversidade cultural de um país que, até então, se via sempre de forma plana e estereotipada nos meios de comunicação. Portanto, havia um desejo de renovação cultural e estética disseminado nessas novas gerações exaustas dos padrões estabelecidos por uma mídia que refletia uma sociedade conservadora e repleta de interditos, dominada por vinte anos de regime ditatorial.

É importante considerar a pluralidade de estilos e propostas surgidas nessa época na qual câmeras de vídeo amadoras e profissionais popularizam-se e as camadas médias passam a ter acesso a um equipamento que até então pertencia somente a emissoras de televisão. Artistas, jornalistas, movimentos sociais, grupos indígenas, empresários da comunicação, todos se apropriam, cada qual a seu modo e com objetivos diversos, das novas possibilidades de comunicação videográfica, criando festivais e redes alternativas de exibição dos trabalhos.

É nesse contexto que se estabelecem, no nosso entender, duas linhagens fundamentais não só para a renovação da paisagem documental como também para a compreensão de um campo no qual se movimenta a produção nacional contemporânea no que tange ao emprego dos dispositivos de interação na conformação de uma sociabilidade documental agenciada no interior da obra. Uma mais experimental, representada pelos videomakers e, posteriormente, vídeo-artistas; e outra menos preocupada em promover rupturas, mas sim em inscrever melhores padrões culturais e estéticos às suas produções. Essa última representada por 
produtoras que desenvolviam seus trabalhos com as exibições mais ou menos acertadas em alguma emissora de televisão de canal aberto.

Nessa linhagem mais "convencional", duas delas se destacam no período, a Intervídeo, de Roberto D’Avila (Conexão internacional, Os brasileiros, Xingu, etc.), já ao início dos anos 80 e, principalmente, à VideoFilmes dos irmãos Walter e João Salles que a partir de 1985 ocupa um importante espaço independente na extinta Rede Manchete produzindo sofisticadas séries como Japão, uma viagem no tempo, China, América, Kracjberg, o poeta dos vestigios entre outras e, posteriormente, na GNT onde desenvolvem uma série de projetos conjuntos.

Na esteira desses moldes de produzir para a televisão a VideoFilmes realiza em vídeo, ao final dos anos 90, um marco do documentário urbano que endossará a retomada do cinema brasileiro ${ }^{19}$. Insistindo em uma estética distanciada e imparcial cara ao jornalismo, Notícias de uma guerra particular, 1999, de João Salles e Kátia Lund aproxima-se do formato da grande reportagem e preocupa-se em construir o conflito desde o relato de todas as partes envolvidas: a polícia, os traficantes e a população. Há, porém, elaborados momentos de cinema observacional quando, por exemplo, o documentarista-câmera acompanha a caminhada dos traficantes dentro do morro ou mesmo o treinamento dos militares em sua base. Sem preocupações puristas, convocam imagens de arquivos de outros documentários e acervos, bem como seqüências de tiroteio captadas pela TV Manchete que à época, pós-advento do

\footnotetext{
19 Numa enquete realizada pela Revista de Cinema sobre os melhores filmes brasileiros da Retomada (1994-2002), eleitos por 40 críticos, jornalistas e pesquisadores, Notícias de uma guerra particular, codirigido por Kátia Lund, foi eleito um dos vinte melhores e mais importantes títulos dos últimos anos entre 210 produções avaliadas.
} 
programa Aqui, Agora, do SBT, trazia a público a paisagem da periferia e seus conflitos cotidianos ${ }^{20}$.

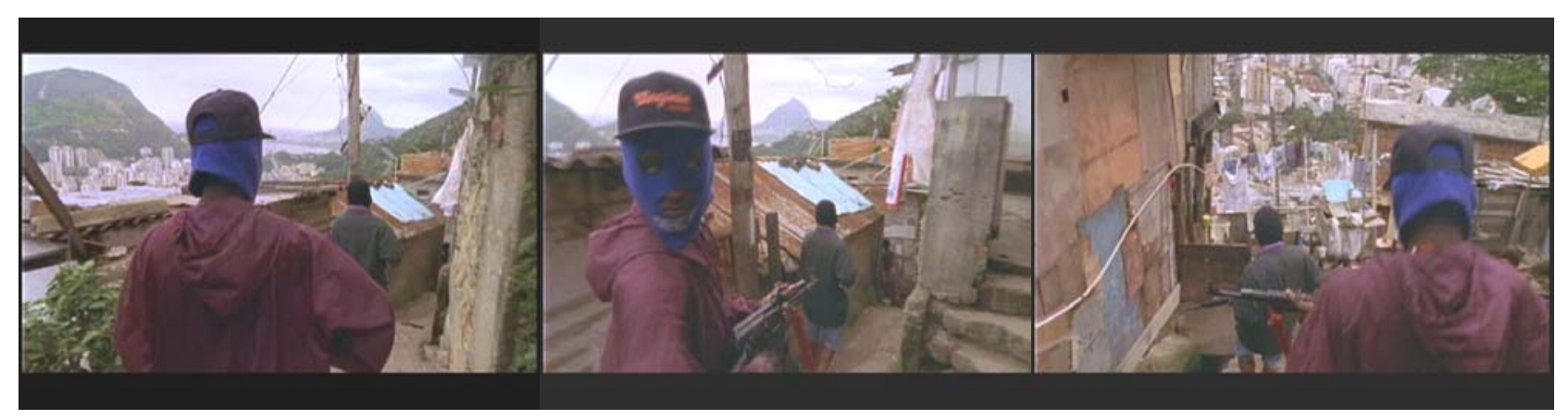

Com direção de fotografia de Walter Carvalho, Salles e Lund traçam um pacto de proximidade com seus entrevistados, construindo um espaço de escuta até mesmo para os traficantes exporem seu ponto de vista do problema. Esse trânsito, acertado de antemão fora das telas entre o traficante Marcinho VP e João Salles, foi motivo de polêmicas e processos a VídeoFilmes, mas possibilitou a subida da equipe ao morro e o acesso a lugares e entrevistas que nenhuma reportagem de televisão ou documentarista havia conquistado até então. Mais tarde, como veremos, José Padilha e Felipe Lacerda retomarão também em chave de uma sociabilidade distanciada nas entrevistas, a estrutura narrativa e mesmo alguns entrevistados de Notícias de uma guerra particular para formatarem o seu próprio documentário, Ônibus 174. Vale lembrar $^{21}$ que Notícias de uma guerra particular foi vencedor do festival É tudo verdade, de 2000, e influenciou uma série de filmes que evocavam os conflitos da violência urbana. Além do já citado Ônibus 174, Cidade de Deus, 2002, de Fernando

${ }^{20}$ Cf. HAMBURGER, Esther. Políticas da representação: ficção e documentário em Ônibus 174. In: LABAKI, Amir; MOURÃO, Maria Dora (orgs.). O cinema do real. São Paulo: Cosac\&Naif, 2005.

${ }^{21}$ Cf. comentários de Carlos Alberto Mattos, João Salles, Kátia Lund e Eduardo Coutinho na faixa comentada do DVD Notícias de uma guerra particular. Videofilmes. 
Meireles e Kátia Lund, O Invasor, 2001, de Beto Brant, O primeiro dia, 1998, de Daniela Thomas e Walter Salles, etc.

Já a cartografia da linhagem mais alternativa representada pelos videomakers que se apresentaram individualmente ou em torno de produtoras independentes é bem ampla e diversificada. Se nos anos 60/70 a cidade foi palco para os cineastas que se preocupavam em assinalar a presença e o trânsito urbano de uma população pobre e migrante espelhada em uma classe média em ascensão, nos 80 os videomakers querem aproximar o olhar do outro, contextualizá-lo, chegar mais próximo com suas câmeras destes seres desconhecidos que coabitam os espaços públicos da cidade. Os moradores de rua, a prostituição e a banalidade cotidiana, já desenvolvendo o que contemporaneamente situamos como relatos autobiográficos, integram as paisagens das representações audiovisuais.

Sandra Kogut, Lucila Meireles, Jacira Melo, Marcelo Dantas, Rafael França e tantos outros nomes caros ao documentário recente têm nos anos 80 suas estréias e experimentos nas artes videográficas. Mais tarde, integrando o que Machado chamou de a terceira geração do vídeo egressa dos anos 90, juntariam-se a essa turma nomes como Kiko Goifman, Carlos Nader, Cao Guimarães e Lucas Bambozi que “tirando proveito de toda experiência acumulada" dos anos 70 e 80 optariam "por um trabalho mais pessoal, mais autoral, menos militante ou socialmente engajado, retomando, portanto, certas diretrizes da geração dos pioneiros" 22 .

É importante destacar, contudo, produtoras que despontaram nesses anos 80 , como a TVDO, uma das responsáveis por radicalizar nas invenções formais e estéticas, evocando as artes do vídeo da "primeira fase" dos anos 70 e estabelecendo 
a origem de um diálogo afinado com as estratégias da arte contemporânea que viria a ser retomado com intensidade a partir da segunda metade dos anos 90, quando as fronteiras entre vídeo-arte e documentário são definitivamente esfumaçadas.

Imagens dissociadas, colagem de estilos compondo mosaicos heterogêneos de gêneros em ruptura: assim pode ser definido, em resumo o processo construtivo de $\mathrm{TVDO}^{23}$.

Também no eixo paulistano, a Olhar Eletrônico acaba por retomar e atualizar alguns elementos conceituais que remontam, em espírito, as estratégias formais do cinema verdade francês e do direto norte-americano. Remarco, prioritariamente, o documentário-reportagem Do outro lado da sua casa, 1986, de Renato Barbieri, Marcelo Machado e Paulo Morelli, onde o entrevistado passa a integrar a equipe transformando-se, nesse deslocamento, em entrevistador.

Em Do outro lado da sua casa o deslocamento do sujeito se dá a partir da apropriação da cena por um papeleiro, Gilberto, que passa a conduzir o rumo do documentário. Retomando o eixo do direto norte-americano, a narrativa se constrói no tempo, no percurso pela cidade que Gilberto desenha acompanhado pela câmera e pelos documentaristas. Ao longo do trajeto eles encontram outros moradores de rua: loucos, bêbados, travestis, personagens das quais Gilberto e "sua equipe" aproximam-se para observar, conversar, confrontar. Nesses momentos o papeleiro tece teorias sobre o mundo, sobre a vida e sobre seus princípios éticos e morais. Volta e meia os documentaristas fazem intervenções a Gilberto e às outras personagens lembrando o mote de seus questionamentos: o que eles pensam dessa desigualdade 
tão grande: enquanto têm homens indo à lua, eles estão ali, vivendo à margem da sociedade. Com espírito de cronistas do seu tempo inscrevem-se desde dentro de suas próprias imagens, deixando transparecer suas preocupações e questionamentos. Mas aqui, diferente da tradição brasileira precedente, já não se tem mais a preocupação de ver como o outro de classe vê. O que conta é o embate das idéias e visões de mundo desse outro trazendo à cena uma cidade impura, do diferente e da diferença, mesmo entre os iguais.

Uma cidade impura onde os bêbados, loucos, miseráveis são olhados pelos olhos de Gilberto sem comiseração e sem o peso da vitimação apesar da proximidade à deterioração. Eis aí um dos diferenciais de Do outro lado da sua casa e onde ele avança em termos de proposta documental urbana: a presença de Gilberto como condutor narrativo, como a voz da cidade que se coloca lado a lado com o narrador. As câmeras observam Gilberto que observa o mundo e que fala de si, falando dos outros e aproveitando cada situação que encontra em seu caminho para proferir suas teses e juízos sobre o mundo. Tudo conformado em um enquanto isso, que o percurso narrativo colado à caminhada da equipe implica em termos de uma aderência ao tempo e movimento do papeleiro.

Enquanto a câmera segue os passos e integra-se à rotina e ao ritmo da personagem, essa, assumindo a sua nova posição de entrevistador, vai conversando com um e outro que, em diferentes condições, habitam de forma nômade as ruas da cidade. É também nesse sentido, de uma personagem que se revela e se constrói ao longo do percurso narrativo, que se modifica a cada encontro provocado pelo e para o filme que nessa quebra de transparência transforma-se ele mesmo acontecimento 
narrativo, é que podemos mais uma vez perceber uma atualização das tradições modernas.

Machado fala que essa geração trará como conseqüência uma outra antropologia e experimentará outras possibilidades entre sujeito enunciador $e$ o representado, investindo na construção de uma proximidade que possibilita falar dos pequenos movimentos do cotidiano, de comportamentos fragmentários e microscópicos que tecem as cidades brasileiras.

Aquele que aponta suas câmeras para o outro não se encontra mais necessariamente numa posição privilegiada como produtor de sentidos, não está mais autorizado a dizer toda a verdade sobre o representado, nem está apto a dar uma coerência impossível à cultura focalizada. Os próprios realizadores não se encontram mais ausentes do "texto" audiovisual, nem se escondem mais atrás das câmeras de modo a sugerir uma pretensa neutralidade. A produção de sentidos e a legibilidade dos novos produtos videográficos vão depender agora de uma capacidade de criar novos processos de relação entre as partes em questão. E o que se busca realmente é menos dizer a verdade sobre o outro, revelá-lo, "traduzi-lo" aos nossos cânones de inteligibilidade, do que tentar construir uma ponte entre duas culturas, para que elas possam finalmente dialogar ${ }^{24}$.

Essa citação de Machado bem parece corroborar a evocação do diálogo reestabelecido pelos videomakers com as tradições modernas. Percepção compartilhada com Andréa França, que refletindo sobre as relações entre documentário e artes visuais percebe nessas diferentes gerações de "vídeo-autores", como os nomeia toda uma "problematização a respeito das imagens do mundo, da

\footnotetext{
${ }^{24}$ Idem, ibidem. Grifos meus.
} 
possibilidade de falar do outro, da dinâmica das subjetividades em jogo (do realizador e do personagem), de modo a questionar a posição privilegiada do diretor como produtor exclusivo de sentido" 25 .

Nessa mesma chave de uma atualização de elementos estéticos conceituais e retomando a metáfora da ponte que evoca Machado, podemos pensar que o próprio acontecimento fílmico é acionado como dispositivo de interação e sociabilidade entre os documentaristas e Gilberto, bem como entre o papeleiro e todos os outros que, através de seu olhar e intervenção, integram a cena. Não foi, $\operatorname{como} \operatorname{sabemos}^{26}$, a primeira vez no documentário brasileiro que esses deslocamentos do entrevistado migrando ao lugar de entrevistador seriam apresentados como uma voz possível (de afirmações, contestações, ambigüidades e contradições), mas a inovação aqui é que bem aos moldes do cinema verdade francês há um efeito de partilha e co-autoria entre a personagem e os documentaristas que contaminam a narrativa e a abordagem daqueles que trazem à cena em sua caminhada pela cidade.

\subsection{A câmera na mão da personagem como dispositivo de interação}

\footnotetext{
25 FRANÇA, Andréa. Documentário brasileiro e artes visuais: das passagens e das verdades possíveis. Disponível em: www. publique.rdc.puc-rio.br/revistaalceu

26 Cf. BERNADET, Jean Claude. Op.cit, em seu comentário acerca de Tarumã, 1975, de Aloysio Raulino, Guilherme Lisboa, MárioKuperman, Romeu Quinto.
} 
Vamos retomar o parâmetro do documentário moderno para restabelecer um olhar acerca dos deslocamentos $e$ assujeitamentos entre documentaristas e documentados relativizando os lugares e autoridades do jogo documental. Podemos pensar que se a tradição observacional do cinema direto norte-americano veio reafirmar a clássica divisão entre sujeito e objeto, no cinema verdade há uma desestabilização desses lugares. Deslocamentos ocasionados, sobretudo, pela integração do olhar do outro ao acontecimento narrativo, bem como pela conseqüente relativização do lugar da autoridade do olhar do autor a partir da noção de partilha com os próprios documentados. É claro que as diferentes maneiras de agenciar os materiais na montagem podem convocar sentidos diversos a essa participação, assim como ressaltar - ou não - as diferenças conceituais e formais entre o olhar do diretor e da personagem.

Crônica de um verão, como sabemos, atualiza em solo urbano ocidental a noção de antropologia partilhada ensaiada por Rouch em suas etno-ficções como Eu, um negro, Jaguar e A pirâmide humana. Nesses filmes o antropólogo-cineasta e suas personagens criavam juntos as situações a serem filmadas e investiam na dramaturgia do imaginário e da fabulação, instaurada pelo método do improviso. Rouch, a exemplo de Flaherty, utilizava as próprias imagens captadas como dispositivo de discussão, partilha e elaboração das próximas cenas a serem filmadas. Mas, ao contrário do mestre que se manteve transparente, o antropólogo afirmava narrativamente o jogo da intersubjetividade incluindo-se no texto fílmico. Sua presença, professada em voz off, situava o espectador dos procedimentos realizados 
para a elaboração do filme e do diálogo que diretor e personagens mantinham ao longo do percurso narrativo.

Quando realiza Crônica de um verão com Edgard Morin, o antropólogo aplica esses princípios de partilha em sua própria Paris, mas brincando ainda mais com os deslocamentos e subversões ensaiados anteriormente. Em uma "dança das cadeiras" cinematográfica sem antecedentes, os realizadores integram-se à cena como personagens, os personagens integram-se à equipe como entrevistadores e o próprio filme e os espectadores ocupam o espaço diegético. Eis aí a gênese documental de todas as desestabilizações posteriores, inclusive a que nos traz Rua de mão dupla de entregar a câmera à mão das personagens.

Profético, em 1973, no IX Congresso Internacional de Ciências Antropológicas e Etnológicas em Chicago, Rouch anuncia em sua comunicação que o vídeo engendraria outras formas de deslocamento e, portanto, de dispositivos de interação entre os sujeitos envolvidos no filme, uma via de mão dupla onde os próprios documentados tornar-se-iam eles também documentaristas:

amanhã será o tempo do vídeo, da restituição instantânea da imagem registrada; quer dizer, do sonho conjunto de Vertov e Flaherty, de um cine-olho-orelha-mecânico e de uma câmera de tal forma participante que ela passará automaticamente às mãos daqueles que, até aqui, estavam atrás da câmera ${ }^{27}$

Jardim Nova Bahia, 1971, de Aloysio Raulino, rodado em 16 mm, foi pioneiro no documentário brasileiro urbano ao integrar as imagens captadas pela própria

\footnotetext{
${ }_{27}$ ROUCH, Jean. La caméra et les hommes. In: France, Claudine (org.). Op.cit., p.71.
} 
personagem ao filme, edificando um novo paradigma em relação aos modelos anteriores $^{28}$. Ao dar a câmera ao lavador de carros Deutrudes, o diretor empreende uma outra maneira de criar proximidade com seu objeto e de transformá-lo em sujeito capaz de proferir um discurso visual de seu próprio universo. Os créditos finais do filme informam quais as imagens captadas por Deutrudes e que as mesmas foram realizadas "sem qualquer interferência do realizador". Postura que Consuelo Lins lê como um desejo de capturar o olhar do outro de maneira depurada ${ }^{29}$. Depuração que é também inscrita no agenciamento da montagem que constrói e demarca o lugar das imagens do realizador, na primeira parte, e aquelas captadas por Deutrudes, na segunda parte do filme.

De forma mais desestabilizadora e impura, esse procedimento invade o documentário urbano brasileiro do século XXI e traz alguns momentos felizes nessa utilização da câmera à mão das personagens como dispositivo de interação e construção do universo alheio. Aloysio Raulino empresta sua experiência de Jardim Nova Bahia para integrar a equipe como diretor de fotografia de O prisioneiro da grade de ferro, 2003, de Paulo Sacramento. O filme nasce de alguns meses de oficinas para capacitar os detentos a utilizarem as câmeras digitais no registro de seu próprio cotidiano, um universo absolutamente estranho e repleto de interditos ao documentarista e sua equipe. Ao contrário de Jardim Nova Bahia, os créditos anunciam uma co-autoria nas imagens, não fazendo distinção daquelas captadas pelos alunos das registradas pela equipe.

\footnotetext{
28 Cf. BERNARDET. Op.cit., p.119-142.

29 LINS, Consuelo. Rua de mão dupla: documentário e arte contemporânea. Disponível em: <www.videobrasil.org.br/ffdossier/Ruademaodupla_ConsueloLins.pdf >
} 
Já nas seqüências iniciais vemos os detentos aprendendo a operar o equipamento, estabelecendo toda uma mise-en-scène da sociabilidade documental e do jogo inter-relacional entre documentaristas e documentados. Mas, ao mesmo tempo em que essas imagens expõem a transmissão de operação das câmeras como dispositivo de interação, anuncia que a autoria das imagens será partilhada e os lugares de enunciação absolutamente relativizados.

Mas ao interior da narrativa há momentos sabiamente agenciados pela montagem, onde somente os prisioneiros falam com suas imagens. Lugares onde só eles poderiam estar, vivendo situações que apesar de degradantes são rotineiras e contadas com leveza e humor (negro) por eles que também brincam de se filmar, de filmar o que vêem, de querer falar o que sentem. Mas, eis aí um dos trunfos de Paulo Sacramento, ao fugir com esse dispositivo da ética da vitimação e alcançar tamanha densidade em alguns fragmentos desse mosaico de relatos.

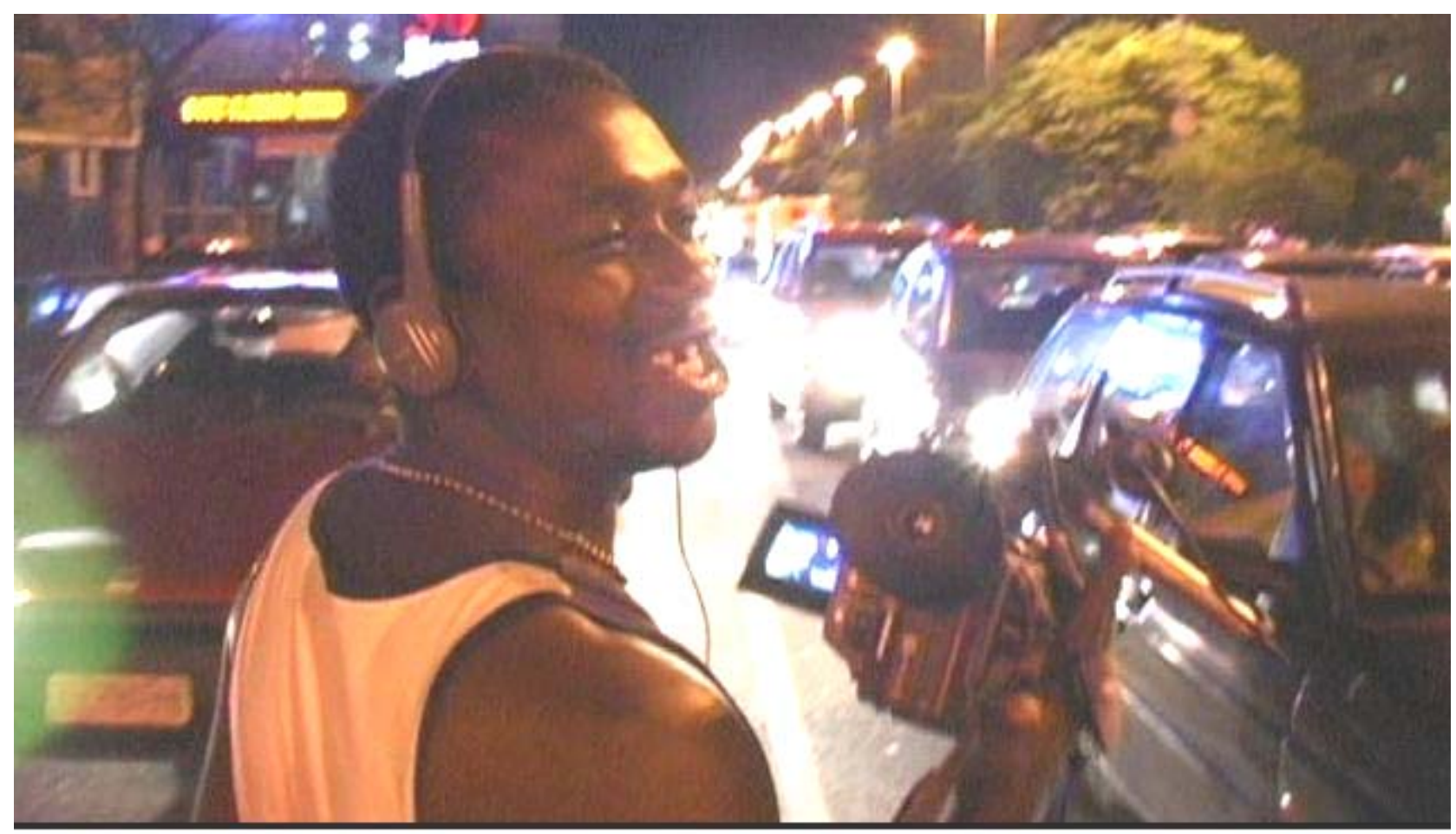


Um outro documentário que serve como exemplo, já que também recorre à entrega da câmera na mão das personagens como dispositivo de interação e de agenciamento da sociabilidade documental, mas focado na construção da cena urbana é Território vermelho, 2004, do vídeo-artista e documentarista Kiko Goifman, que elege o espaço público como palco da interferência que realiza com sua equipe.

O realizador convoca seis personagens que atuam nos semáforos da capital paulista, dando-lhes uma câmera de vídeo para com ela realizar suas intervenções aos motoristas nos sinais fechados. Divididos em blocos distintos flanelinhas, vendedores ambulantes e artistas de rua tornam-se, momentaneamente, cinegrafistas e emprestam sua experiência na cidade para formular suas próprias imagens que são editadas com aquelas da equipe de filmagem.

As personagens e atuações são efêmeras, precárias e instáveis, bem ao ritmo da troca de sinalizações dos semáforos nas grandes cidades. Da mesma maneira, o resultado dessas imagens, precárias e tremidas, confere um estatuto ainda mais frágil e impermanente às relações. Podemos mesmo pensar em uma sociabilidade documental efêmera tanto da equipe em relação a suas personagens, como às personagens-câmeras em relação aos motoristas que convocam a contracenar com elas. Situações que se estabelecem no interior do quadro fílmico, sempre transbordado e evadido pelos fluxos urbanos e pelos constantes movimentos conferidos a esses diferentes jogos de olhares-câmeras agenciados na montagem: o da equipe do filme e os dos personagens-cinegrafistas. 
O projeto nasceu da implicância que tenho com as câmeras de vigilância - as câmeras escondidas. O filme é um pouco "violento" nas abordagens, mas queria ver a reação das pessoas diante da materialização das câmeras invisíveis: algo como a câmera desceu do semáforo e foi na sua cara, ${ }^{30}$

conta o diretor, que provoca com o próprio dispositivo de interação do filme uma outra intervenção na paisagem da cidade.

Nessa crítica urbana de Goifman à cultura da vigilância as personagenscâmeras transmutam-se em câmeras-personagens, simbiose consagrada nos títulos dos blocos que a um só tempo antropomorfizam o dispositivo de filmagem e coisificam as personagens. "A câmera dança - Luis F. Quiniliano", "a câmera seduz Alessandro J. Guilherme", "a câmera autônoma - Genilson A. Ferreira", "a câmera muda - Dona Roseta", "a câmera roda - Evandro S. de Almeida" e "a câmera clone Márcio F. Santos“. Na verdade as protagonistas de Território vermelho são elas, as câmeras, produtoras da interação e do visível; aquelas que roubam as imagens e às quais os personagens emprestam seus corpos, suas atuações, seus gestos, sua jinga e suas performances para contribuir na conformação da imagem e na abordagem desses outros, esses diferentes e indiferentes, enclausurados em seus automóveis.

"Só as câmeras de vigilância salvam" e "Você já roubou uma imagem hoje?" são as duas primeiras inscrições do filme. Elas precedem uma longa seqüência inicial, toda borrada de vermelho, que tem no foco dos quadros a câmera e o jogo da interação entre a equipe do filme e as personagens que recebem a câmera e instruções para usá-la. Muitos parecem se divertir. No encerramento, sobreposto a vários rostos

${ }^{30}$ Conversa por e-mail com Kiko Goifman em abril de 2006. 
a frase: "a farra da câmera visível" parece sintetizar a experiência do encontro daquilo que poderíamos, afinado a um espírito das artes contemporâneas, denominar como um documentário-intervenção.

Vale ressaltar que seguindo a trilha de Território vermelho, Kiko Goifman realiza ainda em 2004 uma série de vídeo-crônicas ${ }^{31}$, persistindo no dispositivo de entregar a câmera para suas personagens fazendo emergir desde a utilização desse dispositivo de interação, o imaginário da cidade. Com duração de um minuto cada, inseridas ao longo da programação da Televisão Cultura Paulista ${ }^{32}$, os pequenos documentários apresentam a um só tempo: a paisagem que a personagem tem de sua janela e o interior de sua própria casa, ambas captadas pelas imagens que elas mesmas fazem com uma câmera super-8, emprestada do diretor.

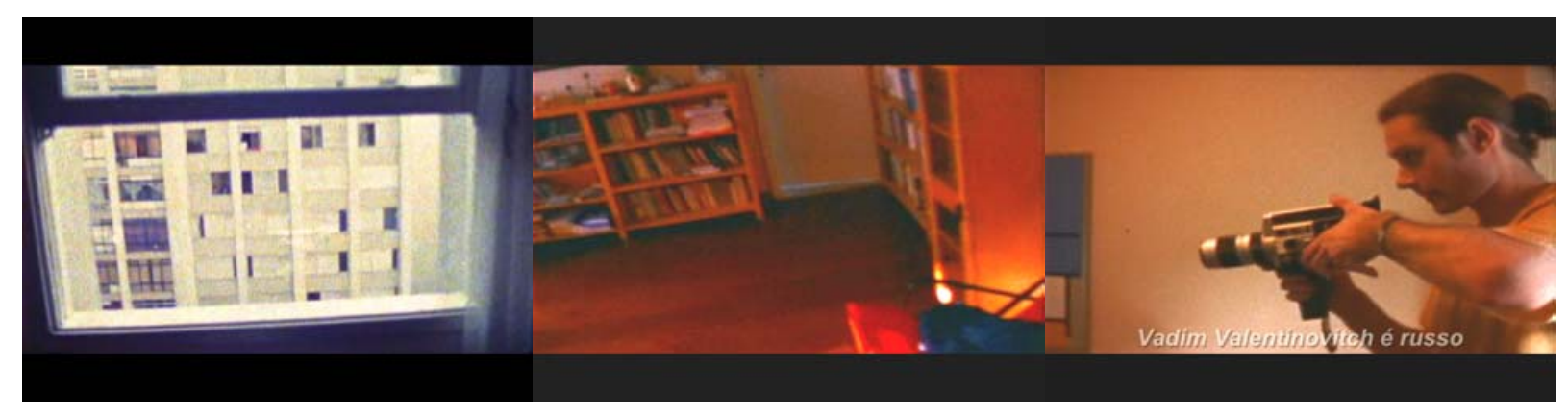

Os seis programetes apresentam a mesma estrutura. A vista da janela, onde se insere o nome do bairro, e o passeio da câmera pelo interior da casa e dos objetos pessoais. É nesse clima de intimidade, que permite o passeio pelo espaço, que as

\footnotetext{
31 "Povos de São Paulo" é um projeto desenvolvido por ocasião do aniversário da capital paulista em 2004. Composto por livro, documentário e vídeo-crônicas realizadas por diferentes documentaristas, entre eles Dainara e Tatiana Toffoli, Jurandir Muller e Rachel Monteiro, cada qual perseguindo estilo próprio.
} 
personagens, sempre em off, narram seu olhar sobre a cidade, seu sentimento de pertença e estranhamento com o novo território de adoção. Agenciamento que coloca-nos ubiquamente na grandiosa e fantasmática São Paulo e no aconchego da casa. O último plano, realizado pelo documentarista-câmera, revela a figura da personagem filmando, o que denuncia também o som da filmadora que junto com a trilha está presente do início ao fim da crônica.

Como podemos perceber, dos anos 60 até hoje se engendram diferentes formas de encontro documental. Procuramos, aqui, traçar os estilos narrativos e a partir deles algumas linhas estético-conceituais as quais se filiam os documentários que iremos analisar nos capítulos seguintes. Interessam-nos a diversidade de imaginários da cidade que eles constroem com seus dispositivos de interação, bem como do estabelecimento de uma sociabilidade documental, sempre ela mesma constituinte da paisagem cultural contemporânea que não pode ser pensada sem os seus atravessamentos pela imagem. Uma paisagem documental, portanto, que constitui os fluxos de imagens contemporâneas ao mesmo tempo em que é constituída por eles em um dinâmico e permanente jogo inter-relacional. 


\section{PARTE II}




\section{OS DISPOSITIVOS DE INTERAÇÃO E A CONSTRUÇÃO DO IMAGINÁRIO URBANO NOS DOCUMENTÁRIOS CONTEMPORÂNEOS}

Edifício Master, Ônibus 174 e Rua de mão dupla são, a nosso ver, narrativas que compõe um campo documental amplo, proposto através de seus dispositivos de interação e abordagens diferenciadas em suas aproximações da cidade. Filmes que nos levam a vivenciar sociabilidades documentais distintas, marcadas por efeitos de proximidade, distância e até mesmo de ausência, como veremos nas imagens das personagens-câmeras no filme de Cao Guimarães.

Apesar de encontrarem no registro da fala um solo em comum é no agenciamento das entrevistas com as demais estratégias narrativas específicas de cada filme que emergem as respectivas expressões estéticas inscritas em suas imagens. Jean Claude Bernardet sugere que

as imagens cinematográficas do povo não podem ser consideradas sua expressão e sim a manifestação da relação que se estabelece nos filmes entre os cineastas e o povo. Essa relação não atua somente na temática, mas também na linguagem ${ }^{1}$.

${ }^{1}$ BERNADET, Jean-Claude. Cineastas e imagens do povo. São Pulo, Companhia das Letras, 2003, pg.9. 
Deslocando essa percepção à configuração da personagem cidade e às formas de narrá-la, gostaríamos de reter a idéia que o encontro cineastamundo acionados desde os dispositivos de interação engendram formas de estar um com o outro nas imagens, ou seja, a já proposta sociabilidade documental que inscreve-se estilisticamente nas imagens documentais. Cada obra, portanto, encontrará uma forma de articular no encontro com o universo abordado uma forma de sociabilidade documental e inscrever o imaginário urbano a partir dos agenciamentos mobilizados em sua realização. Estética que pode ser percebida no conjunto da obra, na fruição que permite torná-la pensamento, sensação, intuição.

Coutinho coloca-se em cena e privilegia as conversas que estabelece com os personagens do Master tramando-as, em seus interstícios, com peregrinações da equipe pelo prédio e seqüências de espaços vazios. Privilegiando a fabulação das personagens e sua aderência ao regime cristalino, convoca uma cidade fantástica, tecida desde o interior do prédio, a partir de imagens de ausência.

Em Ônibus 174 Lacerda e Padilha optam por jamais colocarem-se em quadro e integrarem os depoimentos de seus entrevistados, grande parte do tempo em off, como testemunhos e condutores das imagens de arquivo apresentadas na reconstituição do trágico evento e na reconstrução da história de vida de Sandro Nascimento. A ambição por instituir uma narrativa que se quer como prolongamento do real, em regime orgânico e distanciado, reforça o efeito de objetividade almejada pelos realizadores. 
Rua de mão dupla, em sua interface com o vídeo experimental e a arte contemporânea, opera em registro híbrido, convocando dois dispositivos de interação fundamentais e complementares ao sentido da obra. De um lado as personagens, portadoras de câmeras, são responsáveis por parte das imagens, por outro Cao Guimarães, mimetizando-se a proposta da ausência que pontuará todo o filme, aciona o dispositivo da entrevista e de forma impessoal, sem deixar rastros em cena, recolhe o relato de experiências e construção da imagem do outro professados por suas personagens. Com essas opções narrativas, encharcadas de ações contraditórias e ambíguas, características do regime cristalino, Rua de mão dupla nos traz o imaginário da cidade a partir do estranhamento (do espaço) do outro. 


\section{EDIFÍCIO MASTER: A SOCIABILIDADE PRESENTE E A CIDADE}

\section{FANTÁSTICA}

O invisível no cinema é o que, fora do campo, se articula de maneira aleatória com o visível do quadro, mas é, também, ao mesmo tempo, dentro do próprio quadro, aquilo que é ocultado de maneira aleatória pelo desejo do sujeito que olha.

Jean Louis Comolli

Edifício Master nasce da idéia de Consuelo Lins ${ }^{1}$ de fazer um documentário em um prédio de apartamentos no Leme, em parte inspirado pelos dispositivos de realização desenvolvidos por Eduardo Coutinho em filmes anteriores onde permanecia em apenas uma locação: Santa Marta, duas semanas no morro, 1987, Santo forte, 1999, Boca do lixo, 1992 e Babilônia 2000, 2001, todos realizados na cidade do Rio de Janeiro. O princípio da locação única, como esclarece Lins, atuava em sentido do cineasta criar sua "prisão", para que desde aí emergisse a história². Procedimento

${ }^{1}$ Cf. Capítulo sobre o Edifício Master em LINS, Consuelo. Op.cit., p.139-168.

2 Op.cit. p.65. 
que Coutinho define como "cavar"3, ação que delimita um espaço e necessita de um tempo na construção de pontos de vista, na imersão de subjetividades, na vivência das narrativas locais.

Para o cineasta este seria o primeiro filme em território menos assimétrico, não mais na favela ou com pessoas em situações de miserabilidade, como foi o caso de Boca do Lixo, por exemplo, mas em um prédio de classe média, em plena Copacabana. Depois de algumas pesquisas, os realizadores optam por documentar o Master, onde coincidentemente Coutinho já havia habitado há 35 anos. Integra-se à produção Eliska Altmann, ela também ex-moradora, que ainda mantinha vínculos com os antigos vizinhos e, principalmente, com o sindico Sérgio, figura central no acesso da equipe ao condomínio.

Atualizando uma linhagem inaugurada em Opinião pública, 1966, e Retrato de classe, 1978, Edifício Master retoma a vida cotidiana da classe média brasileira como matéria de seu filme. Já havíamos visto que em seus documentários tanto Jabor quanto Bacic, ainda que em registros distintos, acabam por criticar o conservadorismo e inépcia dessa parte da população para promover transformações sociais.

Em Opinião pública, também filmado em Copacabana, um comentário em off baseado no ensaio White collar - The american middle classes, do sociólogo Wright Mills, estrutura todo o filme e acaba por reduzir a riquíssima atuação das personagens a uma simples reafirmação dessa voz do saber. Já Retrato de classe, apesar de já estar mais desprendido dos dogmas e compromissos do "modelo

\footnotetext{
${ }^{3}$ Anotações pessoais da palestra de Eduardo Coutinho na 26a Mostra Internacional de Cinema de São Paulo em 28 out. 2002.
} 
sociológico", ainda instaura-se em chave crítica em relação às frustradas mudanças (de valores sociais, políticos e culturais) ocasionadas pelo conservadorismo de classe. É como se Bacic fosse reencontrar as personagens de Jabor em suas vidas adultas e, utilizando-se da entrevista direta e da ajuda da vidente professora Eunice, confirmasse o desafortunado destino de uma passiva classe média.

Coutinho, de certa forma, compartilha com esse olhar: “A classe média é um zero absoluto, ninguém está interessado nela. É a mais importante das categorias, não pode mudar as coisas, não tem interesse histórico". ${ }^{4}$ Porém, o que faz o diferencial de seu filme é, em primeiro lugar, a forma como desenvolve a entrevista como dispositivo de interação, o fato de estar focado em descobrir outras lógicas de olhar o mundo e, principalmente, em como elas são atualizadas na vida cotidiana de suas personagens. Investindo nesse registro acaba por abrir um espaço de maior liberdade em relação aos seus antecessores, para que seus entrevistados transcendam os clichês de pura representação e se construam longe do estigma de classe ou apesar dele.

A exemplo de seus outros documentários em território carioca, além de incorporar uma "informante-chave" (Eliska Altmann) como ligação entre a equipe de filmagem e o ambiente a ser explorado, Coutinho trabalhou com pesquisadores que permaneceram durante três semanas no prédio, munidos de câmera de vídeo, em um processo de pesquisa de personagens. Foram a partir destas gravações que o diretor conheceu e selecionou aqueles que seriam seus futuros entrevistados, com os quais iria contracenar e interagir. Consuelo Lins observa em Santa Marta, duas semanas no morro que Coutinho adere à prática de integrar à equipe “pessoas que já possuíssem

\footnotetext{
${ }^{4}$ Apud LINS, Consuelo. O documentário de Eduardo Coutinho: cinema, televisão e vídeo. Rio de Janeiro: Jorge Zahar Editor, 2004. p.140. Grifos meus.
} 
uma relação anterior com a comunidade (...), fazendo ou não pesquisa prévia" 5 .

Coutinho aderiu à pesquisa de personagens, em parte, por motivos econômicos, mas acabou incorporando-a conceitualmente. Em Boca do lixo e, sobretudo, em O fim e o princípio, 2005, arrisca um método diferenciado, despojandose de investigações prévias e introduzindo o próprio processo de busca (de personagens, lugar e história a ser contada) ao acontecimento narrativo.

A pesquisa geralmente não é usável, é filmada sem preocupação técnica. (...) tem o lado irritante e ao mesmo tempo indispensável para economia do filme. (...) Na maioria dos casos dá para conseguir na filmagem mais do que na pesquisa. Pelo fato que eu te falei, quando você chega com sete pessoas ao invés de duas, a pessoa já sente que hoje é jogo, não é treino. ${ }^{6}$

Ao final, os pesquisadores conversaram e gravaram com 70 pessoas, 37 delas escolhidas e filmadas para o documentário, sendo que dez ficaram fora do corte final resultando em um filme de 1h50min. As entrevistas são quase todas intercaladas com a circulação da equipe pelo interior do prédio, bem como por imagens de ausências e vazios espaciais.

A montagem, ao menos das primeiras seqüências, foi estruturada no próprio cronograma de filmagem que segue uma certa ordem temática. Primeiro falando sobre o prédio, nas três primeiras conversas, para logo em seguida fazer descobertas

\footnotetext{
${ }^{5}$ LINS, Consuelo. Op.cit., p.62. Cf. também em relação aos métodos de filmagem desenvolvidos por Coutinho em seus trabalhos conferir o artigo de NOVAES, Regina. Santo forte: notas sobre a conversão do olhar. In: MESQUITA, C.; SARAIVA, L. (Orgs.). Mostra diretores brasileiros: Eduardo Coutinho, cinema do encontro. São Paulo: CBB, 2002.

6 Cf. entrevista de Coutinho. Revelações sobre a vida e ponto final. Disponível em: <http://
} 
diferenciadas da vida dos moradores, que têm em comum a presença do sentimento de viver na cidade do Rio de Janeiro, em Copacabana, no século XXI e, é claro, no Edifício Master.

O critério para a montagem foi, na maior parte das vezes, seguir a ordem de gravação, com exceção de alguns ajustes: "tinham três caras que cantavam em seqüência (...). Separamos dois daqueles lá e tinham duas mulheres que tentavam o suicídio exatamente contíguas"7, que também foram deslocadas. Da mesma forma Coutinho migrou para o meio à emocionada performance de Seu Henrique que em sua longa estadia nos Estados Unidos conheceu Frank Sinatra e subiu com ele ao palco para cantar My way. "Ilusão biográfica"8 que o morador atualiza dois sábados por mês, quando coloca a música em volume altíssimo e canta junto para quem quiser ouvir, encenação que refaz para as câmeras do documentário.

Coutinho até tentou em um dos cortes colocá-lo no final, mas dava um tom de desfecho dramático, o que definitivamente queria evitar já que todo o seu cuidado foi desenvolver uma estrutura narrativa sem intenção dramatúrgica. O resultado disso, acredita, é possibilitar um maior espelhamento e identificação entre suas personagens e os espectadores do filme. Nessa direção, de apontar o quanto somos iguais na diferença em solo urbano, o diretor encaminha a seqüência final com planos focados nas janelas do prédio ao lado. Uma imagem que remete a outras e infindáveis histórias.

\footnotetext{
www.criticos.com.br>. Grifos meus.

${ }^{7}$ Idem. Ibidem.

${ }^{8}$ Cf. expressão de Pierre Bourdieu em Raisons pratiques, sur la théorie de l'action. Paris: Éd. du Seuil, 1994.
} 
(...) você nunca sabe quando o filme vai terminar porque não tem ordem dramatúrgica. (...) A única concessão à dramaturgia, (...) é quando no final você tem as janelas. Eu acho que é muito importante a coisa de naquele momento você ver o prédio da frente. Você pode projetar que aquele prédio em frente, que dá para Avenida Atlântica e é maior, não é diferente desse prédio. ${ }^{9}$

Mas essa preocupação anticlímax presente na ordem de entrada dos entrevistados é completamente neutralizada tanto na construção da personagem, foco central e habilidade maior do documentarista que desde os tempos do Globo Repórter destacou-se em sua capacidade de compor a cena para que seus interlocutores desenvolvessem com maestria suas performances.

O que existe para mim é a personagem. E dessa pessoa que gerou uma personagem e numa conversa de 40 minutos sobrou cinco, eu já estou fazendo uma interpretação, uma redução dos 40 minutos. Eu já estou construindo um retrato que é o melhor que ele tem na minha visão, dramaturgicamente, como pessoa humana ou como personagem, se quiser.

Como a idéia que defendemos aqui e igualmente apoiado no antropólogo David McDougall10, Coutinho percebe o documentário como encontro entre o mundo do cineasta e o do outro, com a presença da câmera e por causa dela. É também como encontro, ou conversas, que costuma definir as entrevistas com suas personagens as quais, ao longo de sua obra, transformaram-se tanto em dispositivo de interação privilegiado, como no cerne do seu método narrativo.

9 Cf. entrevista de Coutinho. Revelações sobre a vida e ponto final. Disponível em: $<$ http://www.criticos.com.br>. Grifos meus. 
No Master, a partir do material das pré-entrevistas feitas pelos pesquisadores, ele tinha idéia de quem iria encontrar e o assunto a desenvolver com cada personagem. Mas pra haver encontro - e não desencontros ou confrontos, embora eles nunca estejam descartados -, é preciso haver disposição do outro, acredita Eduardo Coutinho. "Personagem é quem joga o jogo e tem carisma”, afirma. É quem possibilita e tem disponibilidade de compartilhar, quem permite que a empatia aconteça.

Para facilitar a atuação dessa personagem que contracena com ele e, sobretudo, de conseguir sua cumplicidade para que o jogo dramático se realize, Coutinho concebe o que ele chama de vazio ativo, um estado de escuta em que tenta familiarizar o estranho depurando-se, dentro do possível, de preconceitos. Ou seja, conhecer o desconhecido, aproximá-lo, mas tentando perceber o outro dentro de sua lógica, da lógica que organiza o seu mundo.

É uma necessidade imperiosa ter a colaboração do outro. E essa adesão ao objeto implica uma postura que chamo de vazio, no sentido de que o que me interessa são as razões do outro e não as minhas. Então tenho de botar as minhas razões entre parênteses, a minha existência, para tentar saber quais são as razões do outro porque de certa forma, o outro pode não ter razão, mas tem sempre as suas razões. ${ }^{11}$

Esse se colocar no lugar do outro confronta as tradicionais noções de "dar voz ao outro", mito fundado com o advento do cinema direto quando pudemos,

${ }^{10}$ Idem. Ibidem.

${ }^{11}$ Cf. Cinema: entre o real e a ficção. Intersecções, ano 5, n.1, 2003. 
enfim, ouvir as diferentes vozes do mundo professadas pelas próprias bocas das personagens. Porém, a noção de que o documentarista dá a oportunidade ao outro falar cria um pacto falso já que a situação de filmagem, como sabemos, pressupõe uma relação de assujeitamentos, de mútua dependência e negociações entre ambas as partes. Portanto, se o documentarista dá ao outro a possibilidade de se pronunciar, o outro também dá a ele sua voz, corpo e imagem, matérias-primas a partir das quais o cineasta elabora sua obra.

O problema de dar a voz eu acho perigoso, eu não dou voz a ninguém, parece uma coisa autoritária. (...) Outra coisa que me diferencia de outras pessoas que fazem documentário é que eu faço filme não sobre os outros, mas com os outros. Então eu tenho um filme sobre um prédio, mas é um filme feito com moradores do prédio. Sabendo que o que eles me dão eu construo depois. (...) Fazendo com eles eu faço da voz deles a minha voz e espero que quando o filme estiver pronto da minha voz faça a deles. Porque na verdade se eu estou filmando o outro é porque eu não me conheço e eu preciso conhecer o outro para me ver.

Assim se constitui um jogo intercessor, onde personagem e cineasta, em suas invenções e fabulações de si mesmos, espelham-se um no outro, colocando-se em cena em uma dinâmica inter-relacional diante das câmeras e por causa delas. Ou, como afirma Deleuze:

A personagem está sempre se tornando outra, e não é mais separável desse devir que se confunde com um povo. Mas o que dizemos da personagem vale, em segundo lugar e notavelmente, para o próprio 
cineasta. Também ele se torna um outro, na medida em que toma personagens reais como intercessores, e substitui suas próprias ficções pelas próprias fabulações deles. ${ }^{12}$

Um aspecto essencial em Edifício Master - e isso é recorrente nas produções documentais do diretor -, é que o interesse está focalizado na história de vida das pessoas. Ou antes em fragmentos dessa história, em uma seleção de memórias pessoais e afetivas que atuam como condutoras narrativas. Nesse sentido, as personagens se constroem aos nossos olhos a partir de escolhas e valorizações que elegem para se reinventar diante da câmera, desenvolvendo toda uma dramaturgia documental centrada nos registros da fala e da fabulação. Poderíamos mesmo dizer que estamos falando em um espaço narrativo transformado em tempo subjetivo, em tempo de histórias, de memórias e de escuta.

\subsection{Um filme de visitas}

Edificio Master trama-se aos nossos olhos como um filme de visitas onde estamos sempre em seu interior perambulando pelo prédio, dentro dos apartamentos, assistindo as conversas que Coutinho estabelece com os anfitriões. Conversas impregnadas por uma estética da proximidade, com movimentos que tendem ao zero enquanto recolhem curiosidades e confissões, ancoradas nos relatos dessas personagens que, por princípio, Coutinho verá pela primeira vez no momento da entrevista, sem um antes, nem tampouco depois.

${ }^{12}$ DELEUZE, Gilles. Op.cit., p.185. 
Dogma que rebate na já vista percepção simmeliana das relações de sociabilidade na vida moderna. Um jogo do presente, onde o que vale é somente o momento de seus acontecimentos e no qual seus integrantes, embora sem vínculos duráveis, devem dar o melhor de si para que a interação aconteça. Neste sentido, da afirmação de um encontro para o filme, Coutinho vivencia em Edifício Master o exercício da sociabilidade documental ${ }^{13}$, repletos de sua concepção de intimidade efêmera, por assim dizer.

É na precária associação que se dá no momento da filmagem, acredito, que busca construir um contexto individualizador, como sendo aquele em que focaliza o indivíduo como a unidade significativa e em torno do qual desenvolve um sistema de relevâncias. ${ }^{14}$ Focalizações que espelham no entrevistado "um desejo de apropriação da cena, (de) tornar o momento de filmagem como afirmação de si em consonância com a situação dialógica aí procurada. Compor um estilo, um modo de estar e de se comunicar". 15

Durante suas "visitas" aos apartamentos Coutinho, com uma única exceção quando fala com Daniela, jamais estará em quadro. Em algumas ocasiões mantém-se mais econômico e silencioso, em outras, quando percebe que as personagens podem render bons depoimentos, investe com intervenções pontuais, conferindo um efeito maior de reciprocidade e interação característicos da conversa que o diretor tanto preza.

Como na maior parte dos filmes do diretor a balada, o movimento e os

${ }^{13}$ Cf. expressão de VELHO, Gilberto. Subjetividade e sociedade: uma experiência de geração. Rio de Janeiro: Jorge Zahar editor, 2002. p. 13.

${ }^{14}$ Op.cit., p.85

${ }^{15}$ XAVIER, I. Op.cit., p. 56. 
deslocamentos são feitos, sobretudo, por ele e por sua equipe de filmagem. São eles quem descortinam o espaço e permitem ao espectador apreender uma certa geografia do interior do prédio. E é assim que a figura de Coutinho, como personagem de si mesmo, nos será apresentada: circulando com as equipes do documentário, comandando ou fazendo-se preceder pelas pesquisadoras na chegada aos apartamentos.

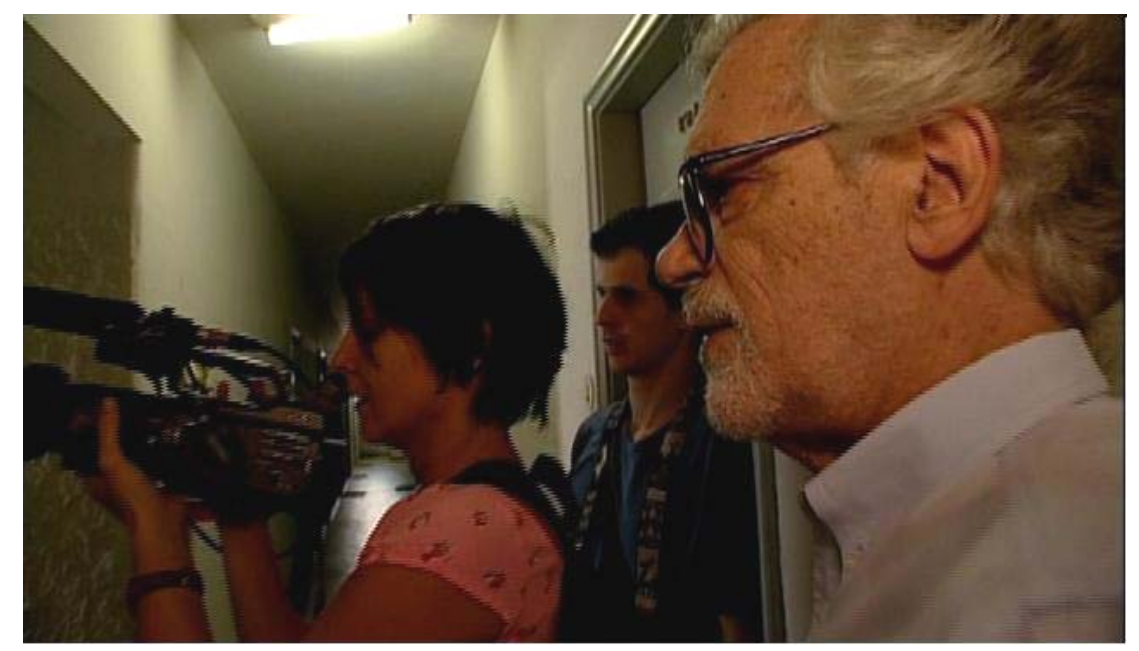

Parafraseando Noel Burch, em sua análise acerca dos espaços narrativos, que exemplifica com Nana, 1926, de Jean Renoir: em Edifício Master o espaço fora da tela é de igual importância ao espaço da tela. ${ }^{16}$ Esse "fora da tela", nos diz Burch, ainda terá duas dimensões: a concreta, quando aquilo que até então permanecia ausente vem a se materializar diante das câmeras e a imaginária, referência fabulada, imaginada, sugerida, mas nunca transformada em cena. E a cidade, nessa perspectiva, habita o invisível, está fora de campo já que não há uma única imagem que não tenha sido captada de dentro do prédio, mesmo aquelas em que a referência externa se faz 
sutilmente presente.

Assim, a arquitetura narrativa do documentário de Eduardo Coutinho ancorase na dinâmica desses fluxos espaciais, jogando com ambigüidades e tensões tanto entre o interior e o exterior (sendo que com diferentes dimensões desse exterior porque o temos em relação ao espaço público, mas também contrapostos aos espaços de circulação do prédio), como entre o visível (os corpos/espaços) e o invisível (as imagens que as personagens evocam em suas fabulações, mas permanecem ausentes). É a partir desses movimentos que articula a construção de um imaginário urbano.

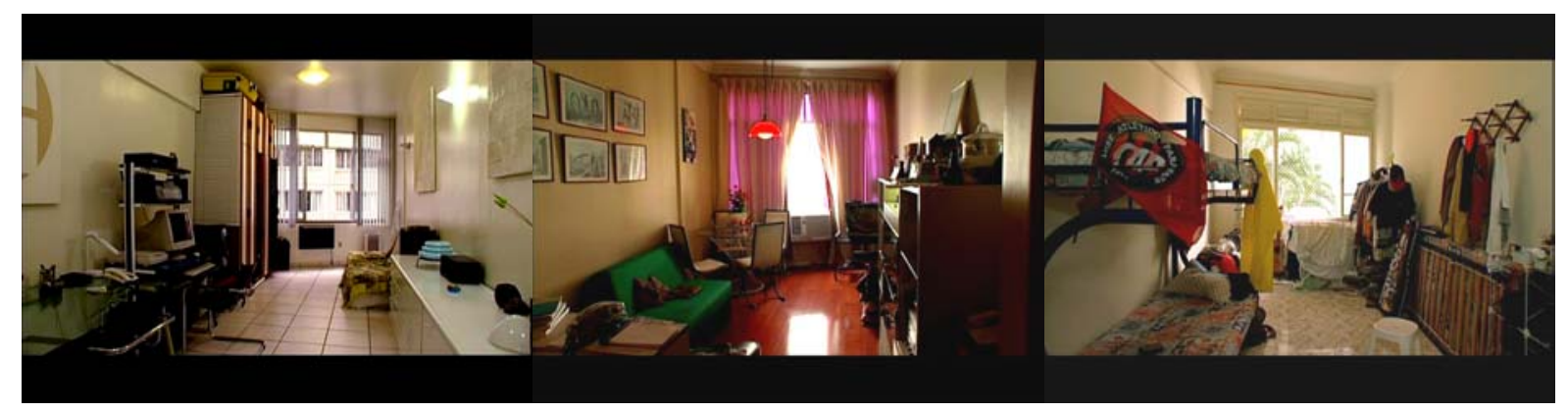

\section{2. Polifonia dos vazios}

Nessa dimensão os vazios, silêncios e "imagens de ausência"17 intersticiais às entrevistas adquirem um caráter polissêmico. De um lado, remetem-nos ao estado de escuta no qual permanece Coutinho. Um interstício de depuração e preparação a uma nova história. Por outro, investem em um "campo imaginário", aquele que nunca nos é

17 Cf. a riqueza da expressão em VERNET, Marc. De l'invisible au cinema: figures de l'absence. Paris: Cahiers du cinéma, 1988. 
mostrado e que no conjunto da obra causam "uma certa perturbação, ocasionada pela ambigüidade de seu status". ${ }^{18}$

Mas o que são os vazios? Seqüências dos interiores dos apartamentos, sem presença humana, sempre captados do ponto de vista da porta tendo as janelas com o ponto de fuga, ou mesmo das janelas dos corredores, igualmente "silenciosas"; planos fixos que comungam com a estética das câmeras de vigilância espalhadas pelo prédio e que captam presenças tão tênues e efêmeras como um menino ao fundo do corredor que bate à porta de um vizinho para um gato entrar, um faxineiro que circula pelos corredores, um segurança que faz sua ronda, etc., bem como imagens captadas pelas próprias câmeras de vigilância que Coutinho incorpora ao filme para documentar o (não) movimento do prédio, inclusive a sua própria peregrinação. Imagens, na maior parte das vezes, "desenquadradas", bem na noção que lhe confere Bonitzer ${ }^{19}$ em sua análise do cinema moderno, com vazios ao centro, com distâncias entre a câmera e o ponto de fuga. Vazios e ausências que se confrontam com os depoimentos nos quais o espaço privado é atravessado pelas memórias, proximidades e desestabilidades do espaço público (o caos e a multidão de Copacabana) e da pregressa vida desordenada do prédio permeado e permeável ao conflitante mundo urbano ("um antro de perdição", como diz uma moradora).

Ao longo da narrativa, portanto, nessas sobreposições de imagens e depoimentos, os vazios são habitados e as bordas do quadro fragilizadas em suas ressignificações confirmando todos os espaços como imaginários. Uma imagem nunca

\footnotetext{
${ }^{18}$ AUMONT. Op.cit., p.135.

19 BONITZER, Pascal. Peinture et cinema: Décadrages. Paris: Cahiers du cinema/Editions de l'etoile, 1995. p. 43-61.
} 
está só e o que conta é a relação entre elas, nos diz Deleuze ${ }^{20}$, retomando o regime cristal que, no nosso entender, traduz a alma coutiniana instaurada em Edifício Master.

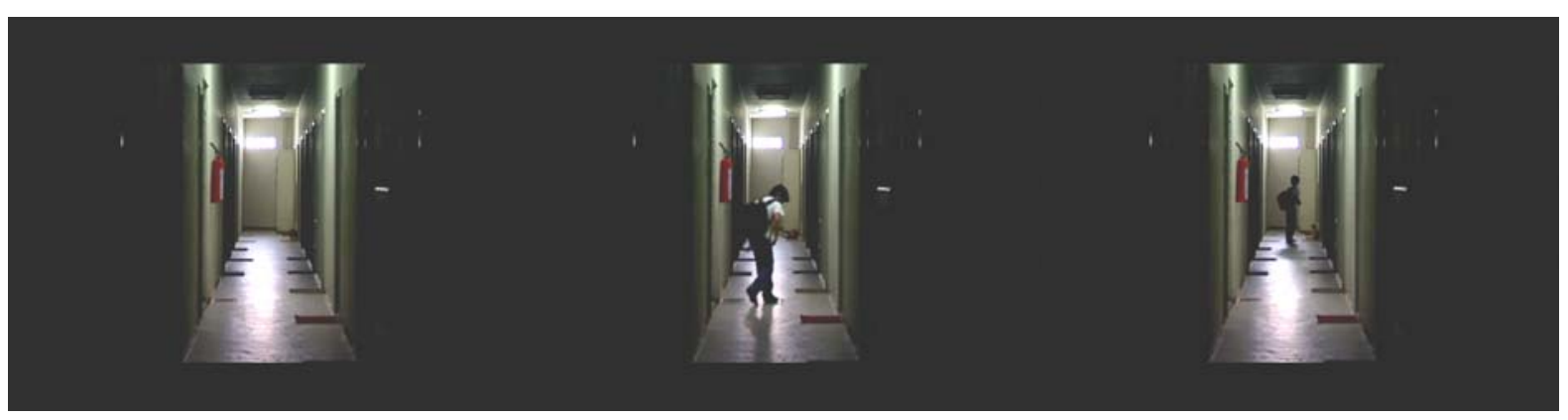

Vi a fábrica, pensei estar vendo condenados (...) Ao invés de um prolongamento linear, tem-se um circuito em que as duas imagens não param de correr uma atrás da outra, em torno da indistinção entre $o$ real e o imaginário. (...) a imagem real e sua imagem virtual cristalizam. É uma imagem cristal. ${ }^{21}$

No Edifício Master os relatos não só povoam, como transbordam os espaços transcendendo aquilo que nos é mostrado. As janelas passam a ser lugares onde as pessoas podem se fazer devorar pela cidade ("pensei em me atirar pela janela", ouviremos das bocas de duas mulheres), os corredores vazios clamarão a presença das centenas de moradores do edifício, as câmeras de vigilância em suas imagens de quase absoluta ausência nos dirão que a qualquer momento o "mundo da rua pode retomar o controle instaurado".

Proposta narrativa que vamos ter já ao início do filme quando Coutinho situa o espectador. No fundo do corredor, na última porta à esquerda, duas mulheres conversam, indiferentes à presença da câmera que as observa. Um movimento

${ }^{20}$ DELEUZE, Gilles. Conversações. São Paulo: Editora 34, 1992. p. 69. Grifo meu. 
panorâmico à esquerda situa esse olhar no centro do corredor e um barulho em off de chaves nos faz imaginar uma porta de onde está saindo o documentarista-câmera. Movimento contínuo, a pan denuncia a presença do corredor vazio à esquerda e avança nele. A partir desse lento travelling, bem ao ritmo da caminhada, uma narração em off com entonação tranqüila e coloquial situa o Master e o dispositivo de produção de filmagem. Momento no qual, a partir da imagem desse corredor vazio, Coutinho nos falará de uma multidão:

Um edifício em Copacabana. A uma esquina da praia. Duzentos e setenta e seis apartamentos conjugados. Uns quinhentos moradores. Doze andares, vinte e três apartamentos conjugados por andar. Alugamos um apartamento no prédio por um mês e, durante sete dias, filmamos a vida de seus moradores.

Desse momento em diante os exteriores, sejam eles os espaços de circulação do prédio ou o espaço público (a rua, o bairro, a cidade), sempre vão ser construídos ou sugeridos por interioridades: pelos vazios dos corredores, apartamentos e elevadores; pelas vistas das janelas e, principalmente, pelas evocações dos narradores eremitas e enguetados do Edifício Master.

Histórias contadas com performances econômicas dentro dos espaços reduzidos dos apartamentos conjugados e restringidos ainda mais pelos planos próximos. Narrativas que pelo seu teor nos remetem ao fora de campo, forçando às margens do quadro, levando-nos a perambular pelos espaços de circulação do edifício, por entre as ruas de Copacabana, bem como a um casamento com os fluxos

\footnotetext{
${ }^{21}$ Idem. Ibidem. Grifo meu.
} 
de imagens que habitam nosso imaginário e que moldam nossa sensibilidade em relação à vida nas cidades brasileiras.

Coutinho é o guia dessa viagem labiríntica pelo Master, que será mapeado nos três primeiros depoimentos como um lugar de passado nebuloso, contaminado pelo caos urbano com circulação de travestis, drogas, mortes e prostituições. Uma desordem controlada com a administração do síndico, Sérgio, que alterna uma pedagogia própria: “Eu uso muito Piaget, quando não dá certo eu parto pro Pinochet". Discursos que fazem eco com as câmeras de vigilância, os corredores vazios e os seguranças circulando pelo prédio; imagens que integram os intervalos entre uma entrevista e outra.

Vera que, segundo conta, já mudou de apartamento mais de 28 vezes nesses 48 anos em que mora no Master, é uma das responsáveis por traçar a instável personalidade pregressa do prédio que descreve de forma macabra.

Aqui era um antro de perdição, muito pesado. Houve suicídios. Houve mortes de porteiros, houve assassinatos, isso já foi muito, muito passado.

Coutinho: Os corredores...

Vera: Nos corredores havia mulheres caídas, filas de homens e mulheres esperando o freguês sair pra entrar outro, sabe. Então havia muitas cafetinas aqui.

Porém, se os depoimentos anteriores se aproximam de uma ética pudica na forma de falar da desordem, Maria do Céu, em sua expansiva performance, irá trazer uma outra ordem de sociabilidade, declarando que eles também viviam momentos prazerosos de trocas, de fofocas, de risadas, de convívio amigável entre alguns 
moradores.

De noite aquela portaria ali era um lugar das mulheres descer e beber junto com os porteiros, toda a noite. Eu também descia lá pela uma da manhã. Eu ficava aqui dentro de casa, eu não tinha sono, eu descia também. A gente comia, daí os porteiros ficavam bêbados, daí um ia dormir abria uma cadeira de praia aí se escondia e ia dormir e a portaria ficava jogada.

Coutinho: Mas a senhora está contando isso com alegria!

Maria do Céu dá uma gargalhada gostosa. Ora, não era muito bom. Era bom na hora, mas na hora da brincadeira, na hora do pega! Então, dali a pouco chegava um rodando a baiana, aí chegava outro com canivete "é hoje!" Aí há pouco chamava a patrulha. Aí quando vinha a patrulha e ela subia acontecia briga. Aí na frente tinha um andaime, tavam pintando o prédio.

(Maria do Céu levanta, interpretando)

Dali a pouco descia um pelado pelas cordas do andaime - já sentando e gargalhando

Coutinho: Que maravilha!

Ah meu filho! Aqui antes do Sérgio...

Esse interior que espelha o mundo da rua, marcado por uma precária estabilidade e permeável aos fluxos da cidade irá tracejar, no percurso narrativo, um território onde as diversidades dos habitantes do Master ganharão força em sua pertença urbana. As visitas de Coutinho aos moradores do prédio acabam por fazer emergir nas suas personagens o espelhamento da diversidade de mundos sociais que povoam as ruas de Copacabana. A cidade habita o Master. 


\section{3. A palavra encarnada}

Essa implosão do quadro em prol do invisível e da imaginação se dá, em parte, pela estética da proximidade desenvolvida por Coutinho que em seus filmes, sobretudo após Santo Forte (1999), privilegia a "palavra encarnada22 como recurso narrativo, como acesso ao imaginário. Um cinema da palavra e do corpo, mas, sobretudo, da palavra no corpo. Da palavra e do corpo presentes em cena, atuando e interagindo." A forma de falar, diz Coutinho ${ }^{23}$, muitas vezes é ainda mais importante do que aquilo que se está falando.

Nessa perspectiva, em Edifício Master o que conta é a fabulação do entrevistado, as imagens que o mesmo evoca enquanto fala. Assim, a construção da memória, do passado ou de algo/alguém que não está ali é sempre sugerida pelo jogo das palavras proferidas pelas personagens e não por imagens exteriores. Não há imagens, nem sons, que não estejam no presente, no aqui e agora do acontecimento. Uma afirmação do presente em que todas as palavras são boas palavras, são as palavras certas, são aquelas que se transformam em ação, em intriga, em narrativa, em imaginação. São as palavras que constroem o espaço necessário para a eclosão da personagem, para a manutenção do jogo da interação, da inter-relação e da reciprocidade.

\footnotetext{
${ }^{22}$ Cf. Revelações sobre a vida e ponto final. Op.cit. Nessa entrevista Coutinho comenta sua concepção
} de "palavra encarnada", afirmando a presença da personagem e suas influências de Shoah, 1985, de 
É nesta dinâmica de testemunhos de singularidades urbanas regidas na palavra encarnada que Coutinho arquiteta a grandeza de suas personagens e, conseqüentemente, de seus filmes. Até mesmo nas reminiscências dos eventos dramáticos das histórias de vida é comum os discursos não soarem ressentidos. ${ }^{24}$ Ao contrário, as mazelas cotidianas podem ser expostas pelos entrevistados permeadas de positividades, inteligências e prazeres pela vida, afirmando constantemente a pluralidade existencial e um "apesar de".

É como se estas personagens, ao contarem de si mesmas, reinventando e refabulando suas trajetórias para a câmera, transformassem suas falas em discursos poéticos, discursos simbólicos que encontram a narrativa em seu sentido pleno e primordial, de veículo da experiência humana". ${ }^{25}$ É esse o caminho que nos leva à Copacabana.

\section{4. A cidade fabulada}

A entrevista com Ester é inaugural em diferentes aspectos. Tanto ao descentrar o tema do Master, que até então vinha sendo desenvolvido por Vera, Sérgio e Maria do Céu, como ao tramar sua história de vida a eventos dramáticos ocorridos no espaço urbano. Através de sua fala passaremos a compor essa Copacabana imaginária. Acompanhando suas lembranças, saberemos detalhes do assalto que aconteceu quando ela "ia passando na Siqueira Campos, ali na porta da

Claude Lanzman, bem como do cinema de Jean-Marie Straub.

${ }^{23}$ Idem. Ibidem.

24 XAVIER, Ismail. Documentário e afirmação do sujeito: Eduardo Coutinho na contramão do ressentimento. In: ENCONTRO ANUAL DA SOCINE, 6., 2002, Niterói. Anais... Niterói, 2002.

${ }^{25}$ Cf. MENESE, Adélia. Do poder da palavra: ensaios de literatura e psicanálise. São Paulo: Duas 
Telemar" e um rapaz, acompanhado por uma moça, a abordou com um revólver. Voltaremos ao apartamento com os dois e veremos Ester ajoelhada, com muito medo, em frente a um "rapaz bonito, branco, bem vestido, mas muito bem vestido mesmo" que quer seu cartão da Caixa Econômica. A senhora nem consegue falar. Abre a gaveta, joga tudo em cima da cama e não acha o cartão. Arrasta-se até ele, segura sua perna e implora que ele não aperte o gatilho. Sobreposta a esse repertório imaginário evocado por suas reminiscências, temos agora, no momento presente da conversa, Ester chorando. “Daí ele foi, eu fui com ele. Ele tirou todo o meu dinheiro, oito mil reais. E sempre na ameaça do revólver." Ela volta para casa e apesar de ter pensado no suicídio está ali, sentada na cadeira, nos contando sua história. Nós vemos a Dona Ester e construímos a partir da imagem dela e de sua fala essas outras imagens. Mesmo que sejam as de fragmentos de uma cidade que não conhecemos. Ou que conhecemos a partir de outros fragmentos e que ressignificamos para compor a história.

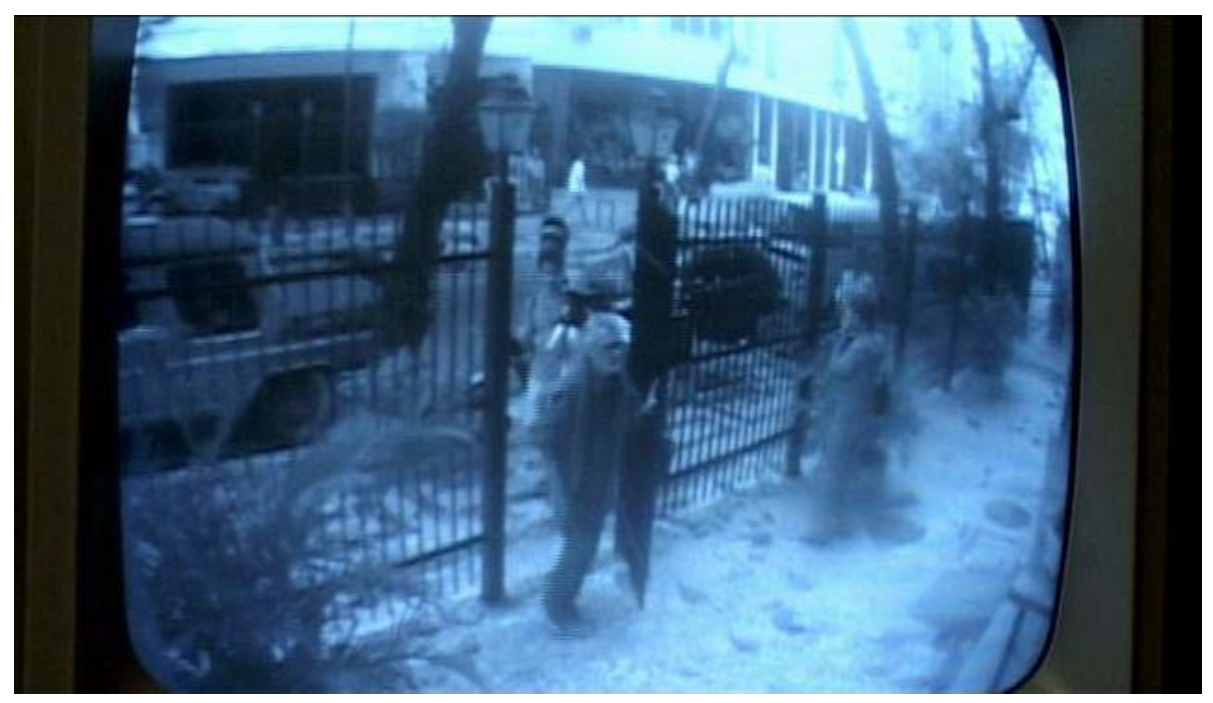

Nessa perspectiva o espaço público é um fantasma. Ele aparecerá uma única 
vez, na primeira cena do filme, em uma imagem com definição precária em relação às outras, construída do ponto de vista do interior do prédio ${ }^{26}$, onde através do monitor de uma câmera de vigilância aparece Coutinho e parte de sua equipe, já se filmando, entrarem no prédio, integrando-se à narrativa como personagens de si mesmos para desde aí atuarem e contracenarem com as personagens escolhidas para o filme. É a única vez que veremos o movimento da rua. As pessoas, os carros, a calçada. Em uma perspectiva de inversão, essa cena pode ser vista como a cidade que entra no prédio e contamina a fala das personagens, incluindo a do próprio realizador.

Como já falamos anteriormente, o off inicial faz com que a referência externa surja pela primeira vez e contextualiza o local onde o Master se situa: Copacabana, a uma quadra da praia. Mas é somente a partir da entrevista de Ester que essa presença invisível passa a habitar a fala de alguns entrevistados. Geralmente provocados pelo diretor, a evocação do superpovoado bairro carioca irá arquitetar a personalidade de uma cidade sob as leis das grandes cidades brasileiras. As imagens fabuladas pelos entrevistados, que oscilam do lazer à violência, com destaque para os constrangimentos da vida na metrópole, oferecem ao espectador o tecido a partir do qual a subjetividade e, portanto, a imaginação desses moradores se alimenta, mesmo aqueles que não falam diretamente de Copacabana. Ela é a matéria que molda grande parte de seu imaginário e que vai impregnar as falas das personagens, entre elas o próprio Coutinho.

Curiosamente o Rio de Janeiro, assim como Copacabana, em diferentes

\footnotetext{
${ }^{26}$ LINS, Consuelo (2005), em sua observação de que "no Master o mundo desapareceu", afirma que todas as imagens foram captadas do interior do prédio.
} 
intensidades, é diluído ao longo do percurso narrativo e a um espectador desavisado. Esses lugares se compõem sem referência geográfica precisa. O depoimento da Dona Ester é um dos raros momentos em que a cidade aparece em primeiro plano, quando diz: “A gente mora no cartão postal do Rio de Janeiro que é Copacabana, mas é muito violento aqui, é muito violento". E, em seguida, busca nossa cumplicidade em seu sentimento contando a história do assalto. Nessa direção, outras entrevistas vão reforçar esse aspecto "muito violento" do qual fala Ester.

Os entrevistados que falam sobre a cidade, para além da multiplicidade de elementos dramáticos a partir dos quais elegem para construir suas personagens; ou seja, para além de tudo o que representam, são também porta-vozes de Copacabana, desse lugar aberto, indeterminado e polifônico que se trama como imagem urbana. Através das conversas, ficamos sabendo que o Edifício Master localiza-se em um lugar movimentado da cidade. “O que me incomoda hoje, diz Marcelo, é que a realidade de Copacabana impregna muito a vida da gente. É (...) é só sair na rua e ver garoto cheirando cola, prostituta, prostituto, traficantezinho... é demais."

O apartamento de Marcelo é diferenciado. Sem paredes, todo pintado de branco, cozinha bem equipada em estilo americano, com balcão. Ele conversa com Coutinho em frente a um computador. Ao fundo vemos um cabideiro cheio de camisas que estão sendo passadas pela empregada, também em quadro.

Quando eu cheguei no Master eu levei um susto. Meus Deus! Mais um prédio desses em Copacabana. Porque eu já tinha habitado não exatamente, mas freqüentado um outro apartamento naquela região da Barata Ribeiro (...) quer dizer o fato de ter essa diversidade de pessoas aqui não me incomoda muito, mas eu acho que é mais a 
concentração. O número é opressivo, não é o fato delas serem diferentes, isso eu acho interessante.

Cristina complementa esse cenário. Provavelmente egressa de um ambiente mais seleto daquele em que hoje vive, foi expulsa da casa do pai por conta de sua gravidez inesperada. Mora no Master contra sua vontade e ainda parece sentir com mais intensidade os constrangimentos da vida no prédio e da diversificada Copacabana.

O que me incomoda é o barulho, conviver com a vida das outras pessoas entrando pelo vão da janela (...) Copacabana é aterrorizante. Antropologicamente acho tudo muito interessante, essa miscelânea, mas na grande maioria eu adoraria matar essas pessoas que batem em mim. Os ambulantes, o caos no trânsito.

Mas, sem dúvida, é Daniela uma das personagens mais marcantes na expressão de um espírito da vida urbana. Quase todo o tempo de lado, sem olhar nos olhos de Coutinho, declara-se absolutamente avessa ao convívio social.

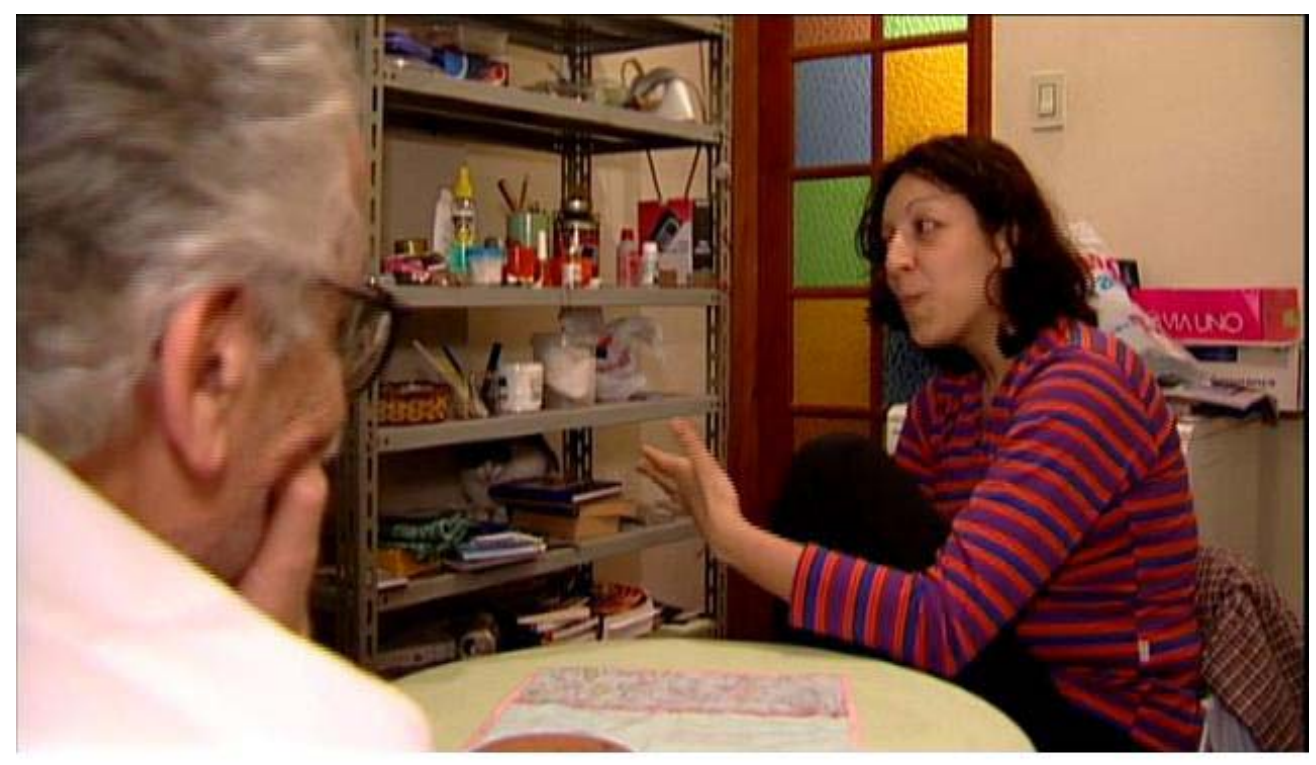


Eu tenho problemas de neurose e sociofobia e a aglomeração típica do vai e vem de Copacabana faz com que eu chegue em casa muito estressada.

Coutinho: Multidão, essa coisa?

Daniela: É porque eu não sei se são pessoas demais ou calçadas muito estreitas ou se é uma fusão desagradável dos dois elementos. Eu sei que pode ser feio, mas eu muitas vezes fico contente quando eu subo e desço o elevador sozinha, não porque eu não vou ter que parar, mas porque eu não vou precisar ver, nem ser vista.

Mostra um quadro que pintou: A floresta do meu desespero.

São os olhares que colocam a selva de pedra como um lugar em que há muita paranóia, muita invasão, em que, de alguma forma parece que estamos sempre sendo assistidos. Esteticamente é ridículo, mas eu não ligo, porque não tenho pretensão e isso aqui no dia foi balsâmico, eu resolvi muitas coisas

Consuelo Lins, em uma análise de alma simmeliana, diz que o depoimento de Daniela

retoma, concentra e explicita, quase didaticamente questões fundamentais para o filme e que atravessam em filigramas diversas falas. Solidão, anonimato, visibilidade, reserva, antipatia e até mesmo aversão em relação aos outros, vistas como reações absolutamente necessárias sem as quais a vida na grande cidade se tornaria insuportável. 27 
Depoimentos que nos trazem uma Copacabana de paisagem social plural, intensificada "pela fusão desagradável de pessoas demais e calçadas muito estreitas", para retomar a fala de Daniela. Uma vivência que se dá a partir da proximidade geográfica e distância social, para retomar Simmel, com multidão, violência, assaltantes, bancos, bares, camelôs, movimento, prostituição em todas as idades e gêneros, traficantes e trânsito.

Mas sabemos também que isso não elimina as redes de sociabilidade, dos velhos que caminham no calçadão, como sugere a conversa com Carlos e Regina, que se diz "coroa" e resiste aos convites do marido de ir ao calçadão "ficar sentada olhando as (outras) coroas passarem". Ou mesmo a Copacabana dos bares e da praia, como elogia o mineiro Bacon: “Aqui é bom! Desce e tem um barzinho. Vai até a praia e tá todo mundo correndo". O ex-ator da Globo, Careca, também fará o elogio dessas redes de relações que se estabelecem tanto no prédio quanto à beira mar, com as "velhinhas" suas amigas de caminhadas. Fluxos e contrafluxos que emprestam uma personalidade à Copacabana moldada pelo Master, de dentro dele.

Nesse sentido, Copacabana é edificada em bases sensíveis, é esse lugar fora de campo, fronteira do Master, um espaço público imaginado "para além dos limites do visível, que é evocada e recuperada em sua própria ausência"28, tanto nessas artes do dizer das personagens, como pelas recorrentes imagens intersticiais às entrevistas, que mostram ou mesmo sugerem com sutileza o exterior abrindo o campo e permeando ainda mais a imaginação do espectador.

Posto isso é interessante pensar que imagem de cidade é essa que se molda a

\footnotetext{
27 LINS, Consuelo, op.cit, p.159.

28 CASETTI, Francesco; DI CHIO, Federico,. 1996. Op. cit. p. 140-141.
} 
um espectador que nunca viu Copacabana em sua vida ou mesmo aquele que já a conhecendo adere ao pacto narrativo e, estimulado pelas rememorações e fabulações dessas personagens, bem como pelas suas artes de dizer e narrar, formula sua cidade imaginária. Que cidade se constrói a esse espectador contemporâneo que já moldado em sua sensibilidade por imagens midiáticas é confrontado por uma narrativa que lhe desafia a integrar seu próprio repertório imaginário para compor essas novas imagens?

Sabemos que essa cidade é edificada em espaço narrativo fantástico, aquele onde é possível implodir o tempo e reordená-lo a partir da memória, do imaginário e da fabulação, como propõe Gilber Durand ${ }^{29}$. Espaço que afirmando o cinema (de Coutinho) como arte do presente e da presença abriga os trajetos imaginários e mantém a duração enquanto viajamos no tempo. Nesse sentido percebemos que as imagens da cidade se compõem nesse espaço narrativo fantástico, lugar onde as imagens urbanas propostas em Edifício Master se compõem e a narrativa assume sua riqueza semântica e sua instabilidade de sentidos.

${ }^{29}$ Cf. expressão de DURAND, Gilbert. As estruturas antropológicas do imaginário. São Paulo: Martins Fontes, 2002. p.409-413. O espaço fantástico na acepção do antropólogo é aquele onde é possível implodir o tempo e reordená-lo a partir da memória, do imaginário e da fabulação. 


\title{
5. ÔNIBUS 174: A SOCIABILIDADE DISTANCIADA E A CIDADE VISÍVEL
}

\author{
As imagens não são mais do lado da verdade dialética, do \\ "ver" e do "mostrar", elas passaram para o lado da \\ promoção, da publicidade, quer dizer, do poder.
}

Serge Daney

A idéia de usar o episódio do ônibus 174 e transformá-lo em um filme nasce quando o diretor José Padilha acompanha a transmissão do evento ao vivo pela televisão. Em suas quase cinco horas de duração, o seqüestro, que culmina com a morte de uma refém e do seqüestrador, Sandro Nascimento, estrangulado pelos policias a caminho da delegacia, torna-se um acontecimento midiático, televisionado por emissoras do país e do mundo. Padilha percebe que ali havia um material de arquivo excepcional.

(...) geralmente, seqüestros acontecem em casas, prédios fechados onde você não consegue filmar e aquele era em um ônibus, com estrutura de vidro. Aquilo para mim já era um material inédito. ${ }^{1}$

\footnotetext{
${ }^{1}$ Folha de S. Paulo Online. Acesso em: 5 dez. 2002.
} 
A intenção de realizar o documentário, porém, ganha corpo em janeiro de 2001, quando o diretor assiste Um dia em setembro, 1999, de Kevin MacDonald, sobre um ato de protesto dos palestinos que seqüestram uma equipe de atletas israelense nas Olimpíadas de Munique, em 1972. Inspirado pelo cuidadoso trabalho com as imagens de arquivo e a estratégia de reconstituir o evento a partir de depoimentos dos envolvidos e parentes das vítimas, Padilha inicia seu documentário antes mesmo de captar recursos. "Era uma idéia muito boa para ficar esperando". ${ }^{2}$ Em parceria com o produtor e sócio Marcos Prado, a produção teve início em fevereiro de 2001 e em setembro de 2002 a primeira cópia já estava pronta. “Durante este tempo todo a gente filmou, refilmou, pesquisou e montou" ${ }^{3}$

Foi realmente uma pesquisa densa e uma investigação minuciosa para recompor tanto o seqüestro quanto a trajetória de Mancha (apelido de Sandro Nascimento) em sua vida nas ruas da capital carioca. Documentos, ocorrências policiais, assistente social, familiares, amigos, companheiros de vida, de cárcere e de baladas, bem como um extenso levantamento de imagens de arquivo fizeram parte desse repertório.

Além das mais de 27 horas de imagens do seqüestro, computando aquelas das emissoras de televisão e das câmeras de vigilância da CET/RJ, a Zazen (produtora de Padilha e Prado) teve acesso a dois vídeos amadores realizados pelos alunos da PUC/RJ nos quais Sandro aparece e que pode incorporar ao filme. Um realizado com os meninos que orbitavam em torno da Candelária e outro que registra uma roda de capoeira organizada pelo professor da PUC, grupo ao qual

\footnotetext{
2 Idem.

${ }^{3}$ Idem.
} 
As pesquisas incluíram ainda os enterros das vítimas e cenas de meninos sendo revistados na instituição para menores Padre Severino. Imagens obtidas nos arquivos da Videofilmes e que já haviam figurado em Notícias de uma guerra particular, documentário ao qual Ônibus 174 não somente filia-se, na chave da violência urbana e crítica ao despreparo do Estado em lidar com as excepcionalidades em espaço público, como também empresta elementos caros à sua estrutura narrativa. ${ }^{4}$

De certa maneira, Ônibus 174 pode ser visto como um desdobramento de Notícias de uma guerra particular, já que ambos são ambientados no Rio de Janeiro e apresentam semelhanças visíveis, como, por exemplo:

- As tomadas aéreas que pontuam ambos os relatos e que em Notícias de uma guerra particular se concentram somente na favela, enquanto no filme de Padilha e Lacerda percorrem a cidade do Rio de Janeiro retraçando os trajetos de Sandro e conduzindo o espectador a lugares a partir dos quais a sua história será remontada;

- O enterro das vítimas da guerra urbana como desfecho narrativo. Em Notícias um policial e um traficante mortos em tiroteios no morro; em Ônibus 174 o seqüestrador e sua refém, a professora de 20 anos, Geísa Firmo Gonçalves. De alguma forma é o conflito que migra dos morros ao Jardim Botânico.

Os filmes também têm em comum alguns tipos, como o marginal encapuzado que profere um discurso aterrorizante marcando seu lugar de força e poder no combate e o, então, policial do Bope, Rodrigo Pimentel, que na sua

\footnotetext{
${ }^{4}$ Cf. HAMBURGER, Esther. Políticas da representação: ficção e documentário em Ônibus 174. In: LABAKI, Amir; Mourão, Maria Dora. O cinema do real. São Paulo: Cosac\&Naify, 2005. p.197-215.
} 
entrevista dá título ao filme de Salles e Lund. Em Ônibus 174 seu depoimento reprisará a tese já esboçada no filme anterior de uma polícia despreparada, desmotivada e sem auto-estima. Um dado curioso é que depois de ter atuado em Notícias de uma guerra particular, Pimentel larga a polícia e passa a fazer cinema, sendo um dos co-produtores de Ônibus 174 e co-roteirista de Tropa de elite, 2007, primeiro longa ficção de José Padilha, que traz em registro ficcional parte de sua experiência de vida no Bope. O ex-combatente já havia narrado sua experiência em um livro, Elite da tropa, ${ }^{5}$ que escreveu com o antropólogo e ex-secretário de segurança do Rio de Janeiro, Luiz Eduardo, ele também um dos entrevistados de Ônibus 174.

Bem a propósito, esse é um outro ponto que vincula os documentários cariocas, a presença de especialistas a quem fica reservada a tarefa de equacionar a tese central do conflito urbano e da narrativa. No caso de Notícias de uma guerra particular, o delegado Hélio Luz expõe a teoria de que é mais vantajoso trabalhar para o bem remunerado tráfico do que ganhar salário mínimo e alerta que a "polícia é política", pois sua função é a de garantir a manutenção de uma "sociedade injusta", onde "o excluído fica sobre controle","6 cerceado em muros simbólicos.

Em Ônibus 174 a personagem convocada é Luiz Eduardo Soares que, como veremos, aposta na teoria da invisibilidade da sociedade em relação aos excluídos como geradora da violência urbana e da polícia como principal produtora e mantenedora dessa situação. Conceito capitalizado no desenvolvimento plástico e narrativo pelos diretores que, em contraponto à teoria apresentada pelo especialista, exacerbam a visibilidade do espaço urbano, das câmeras de vigilância e da mídia.

\footnotetext{
${ }^{5}$ O livro foi lançado em 2006 pela Editora Objetiva.

${ }^{6}$ Palavras do entrevistado no documentário citado.
} 
Mas a filiação ao Notícias de uma guerra particular também se dá na construção de um olhar que se quer mais polifônico no tratamento do conflito do que aquele comumente dispensado pela mídia, embora acabe endossando clichês amplamente utilizados por essa e sucumbindo, em muitos momentos, a uma dramaticidade banal, sublinhada pela utilização da música e por uma engenhosa montagem. Contudo, apesar do diálogo afinado com as técnicas e estratégias da grande reportagem, tanto estética quanto conceitualmente, o filme de Padilha e Lacerda preocupa-se em construir uma outra versão aos fatos apostando na relativização da culpabilidade de Sandro, enunciado como símbolo maior da contaminação de um precário e injusto contexto social.

A partir das imagens de arquivos e dos depoimentos dos envolvidos, a cronologia do seqüestro é habilmente reconstruída e serve como eixo condutor para que esse outro Sandro surja aos olhos do espectador. À essa linha temporal, na qual acompanhamos os desdobramentos da tragédia, tramam-se outros testemunhos de amigos e conhecidos que nos trazem fragmentos biográficos do

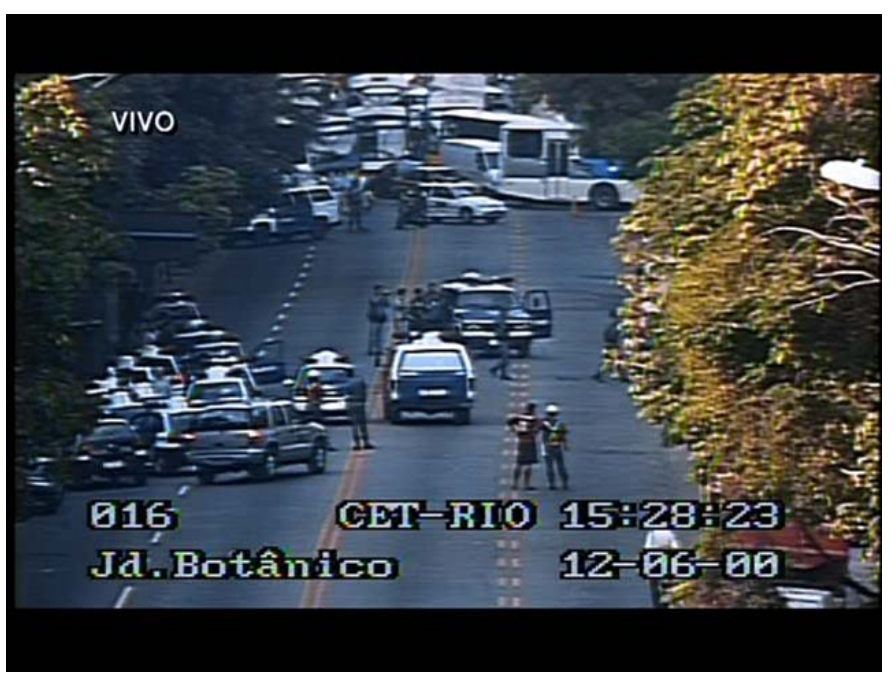
seqüestrador, que ainda pequeno, ao ver a mãe ser assassinada, sai às ruas e nunca mais retorna. Padilha lembra que além de menino de rua "que é importante na vida de todo mundo", Sandro foi uma personagem emblemática já que "às grandes tragédias do Rio de Janeiro - Candelária, Vigário Geral e ônibus 174 -, ele esteve nas 
três".7

No entanto, ao provocarem um jogo de espelhamentos e explicações sociologizantes, os documentaristas acabam por compor uma personagem plana e tipificada, endossando os clichês da pura representação de ser negro, pobre e marginal no Brasil. Cléber Eduardo pontua em sua crítica ao filme "Sandro tem uma definição a priori. É um objeto de estudo moldado enquanto objeto de estudo", 8 aspecto que evoca, em chave de thriller urbano, a "ética da vitimação" já apontada por Brian Winston ${ }^{9}$ em sua análise da herança da escola de Grierson nos documentários contemporâneos.

\subsection{A palavra desencarnada e o dogma da objetividade}

Se podemos pensar que Edifício Master adere à estética da intimidade, engendrando uma cidade e mesmo o prédio a partir das fabulações e reminiscências das personagens, Ônibus 174 ainda que articulado narrativamente pelas memórias dos envolvidos que reconstituem o evento do seqüestro ou que entram em cena para compor uma nova faceta de Sandro do Nascimento, opta por um outro estilo em sua construção remetendo-nos o tempo todo a imagens de arquivo e aquelas produzidas pelo realizador sempre tramadas ao testemunho dos entrevistados. Tanto nas reminiscências do seqüestro como na restauração da trajetória de Sandro, depoimentos e imagens se sobrepõem com o objetivo de criar um efeito de

\footnotetext{
${ }^{7}$ Cf. Entrevista de José Padilha. Disponível em: <http://www.cineweb.com.br> Acesso em: 8 jan. 2003.

${ }^{8}$ Cf. Disponível em: <http: / / www.contracampo.com.br>

${ }_{9}$ Cf. expressão em WINSTON, Brian. Ethics. In: CORNER, John; ROSENTHAL, Alan (Orgs.). New
} 
autenticidade à narrativa. Tudo se torna visível, o que é dito deve ser mostrado, a palavra e a imagem redundam e confirmam-se uma à outra endossando a lógica "da prova da imagem e do dogma da objetividade"10 à qual nossa cultural televisual tão bem nos educou.

Para articular essa pontualidade entre o oral e o visual Padilha e Lacerda utilizam o recurso de mostrar as imagens do seqüestro às personagens antes de ligar a câmera e, se preciso, durante a entrevista também. Dispositivo de aproximação que, segundo eles, enriquece o relato, recupera o caráter emocional e estimula a memória das personagens. ${ }^{11}$ Método que acaba por gerar um efeito de indissociabilidade entre o que é dito e aquilo que está sendo mostrado, fazendo com que a fala assuma rigorosamente o estatuto de narradora das imagens. Essa estratégia utilizada pelos documentaristas é sutilmente revelada ao espectador, quando o comandante da operação fala em off sobre uma imagem onde o vemos conversando com seu superior:

O coronel Penteado me pediu pra eu atirar e perguntou se eu conseguiria fazer um disparo dali onde eu tava (ao lado do ônibus e em frente ao seqüestrador). Eu disse que não, que minha arma estava no colder e eu não teria condições de acertar sem que ele me visse efetuando os movimentos para o tiro. Então ele me disse: vai lá e pergunta a algum voluntário pra fazer esse tiro. E foi exatamente o que eu estou fazendo nesse momento (quando o vemos correr e agachar-se junto a um grupo de policiais).

challenges for documentary. New York: Manchester University Press, 2005. p. 184-193.

10 Cf. NINEY, François. L'épreuve du réel à l'écran: essai sur le principe de réalité documentaire. Bruxelas: De Boeck, 2000. p.232-246.

11 Cf. LAVIA, Jairo. As feridas abertas do Ônibus 174 . Disponível em: <http://www.revistaparadoxo.com> Acesso em: 9 maio 2005 
Nesse sentido, de um corpo-voz que ora aparece ora submerge nas imagens, Ônibus 174 contrapõe-se à noção de "palavra encarnada", chave que o diretor de Edifício Master propõe para a compreensão conceitual de seu filme, que brinca com a total impureza de tempos e espaços. No documentário de Padilha e Lacerda, entretanto, a ambivalência entre presença física e memória ou mesmo da história inscrita na performance dos entrevistados, características dos filmes de Eduardo Coutinho, por exemplo, é abandonada em prol da imagem.

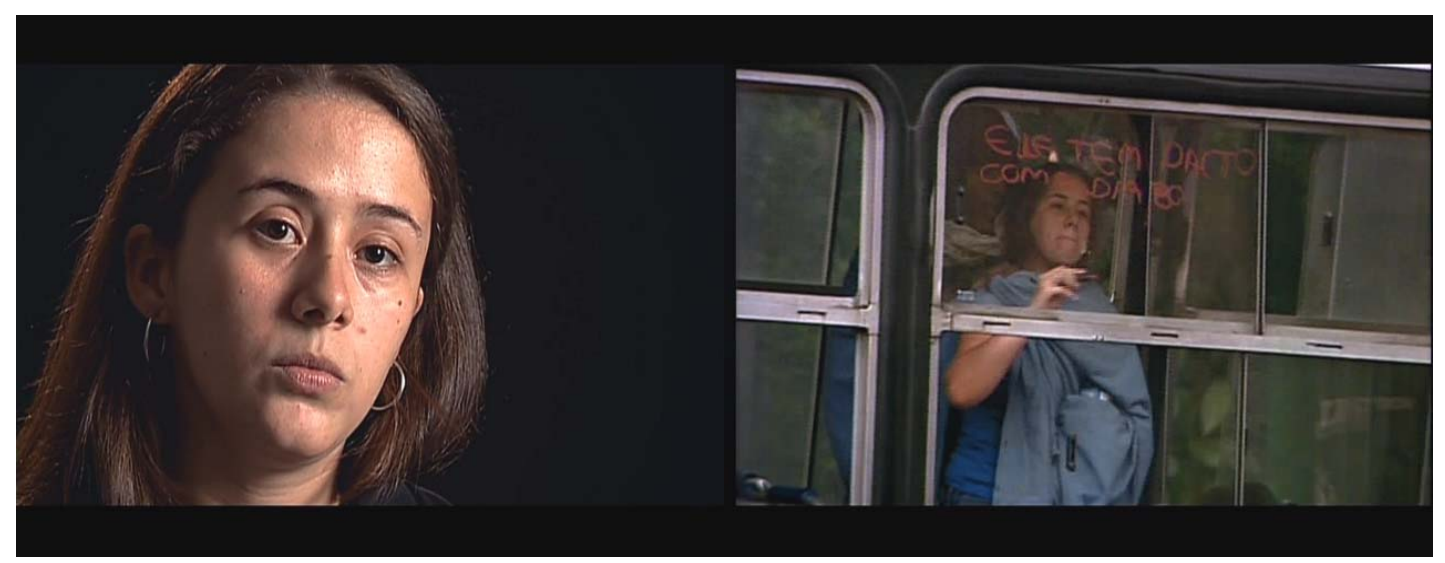

A palavra se desencarna, descola-se do corpo e lança sua voz off em uma pedagogia que orienta o olhar do espectador, de forma canônica e inquestionável.12 Registro explicativo que atua no consenso, sem espaços para reticências e dissonâncias entre o que vemos e aquilo que ouvimos. Reforçando ainda mais essa estética consensual que flerta abertamente com as reportagens de televisão, a música e os efeitos sonoros investem na intensificação da dramatização das situações mostradas, sejam elas momentos de melodrama, suspense ou ação.

12 Cf. análise de NINEY, François, op.cit., p. 237-238. Em chave um pouco diferenciada já que voltado ao estatuto do efeito de sinceridade que a palavra encarnada, propiciada pelo estilo direto, e o 
Para intensificar a impressão de neutralidade, os documentaristas optaram por uma sociabilidade distanciada com seus entrevistados, propondo um jogo de interação domesticado favorecendo o efeito de veracidade desejado. Nesse sentido, os diretores decidem-se pela presença ausente nas conversas com as personagens excluindo do espaço diegético os vestígios dos seus corpos e das suas vozes. "O que me interessa é a objetividade e a verossimilhança, sem aplicar nenhum julgamento",13 diz Padilha em sua franca aderência ao regime orgânico que pressupõe as imagens como prolongação do real engendrando uma "narração verídica que aspira ao verdadeiro",14 para usar novamente a expressão de Deleuze. Nesse investimento, de manter a aparente independência entre sujeito e objeto, ${ }^{15} \mathrm{o}$ caráter testemunhal dos envolvidos - de contar a versão do que "realmente aconteceu", constrói um campo de autenticidade e veracidade incontestável, endossando o mito da transparência.

Ancorado nessa estética da distância, Ônibus 174 estrutura sua retórica apostando na impureza de tempos onde a memória dos relatos é conjugada ao eterno presente do acontecimento reprisado pelas imagens. Não há vazios, tampouco silêncios. As entrevistas são cobertas e intercaladas por imagens e sons. Por essas vias os entrevistados reconstituem tanto os passos da tragédia como a trajetória social de Sandro, sempre com um foco analítico e distanciado, buscando entender sua atitude como um sintoma da doença social que desestabiliza o país.

Aparentemente, até mesmo as vítimas já arrefeceram seus rancores e estão

discurso desencarnado, representado pela voz over recorrente nas emissoras de televisão provocam. 13 Cf. LAVIA, Jairo. As feridas abertas do Ônibus 174. Revistaparadoxo. Disponível em: <http:/ / www.revistaparadoxo.com> Acesso em: 9 de maio 2005.

${ }^{14}$ DELEUZE, Gilles, op.cit., p.157. 
aptas a falar sem qualquer sentimento negativo que possa obscurecer a voz da razão. De alguma maneira, todos estão ali para endossar a tese articulada pelos diretores de um Estado despreparado, de uma sociedade indiferente, produtora de diferenças e preconceituosa. Um país desigual que em suas fraturas sociais promovem a invisibilidade na recusa de reconhecer o outro e de legitimá-lo como portador de existência e singularidades próprias. Máxima proferida na performática desenvoltura de Luiz Eduardo Soares e elevada ao estatuto de tese central pelos realizadores. Nesse sentido, as entrevistas, como dispositivos de interação, em chave distanciada, aliadas às sobreposições de imagens, tornam-se instrumento essencial para conferir um clima de imparcialidade e objetividade no discurso documental de Ônibus 174.

\subsection{A cidade do visível}

Privilegiando uma estética distanciada e analítica, Ônibus 174 atua em chave diferenciada a Edifício Master na composição da cidade. Se no filme de Coutinho temos uma cidade fantástica, fabulada pelas personagens e tecida desde a sua ausência, em Ônibus 174 esse jogo se inverte e as imagens produzidas pelas emissoras de televisão, pelas câmeras de vigilância públicas, por cinegrafistas amadores e pela equipe do filme estarão a maior parte do tempo em cena, impondo a visibilidade da cidade e do espaço público como elemento central ao desenvolvimento plástico e conceitual da narrativa. Padilha e Lacerda trarão, assim, a paisagem urbana ao centro do quadro em uma reflexão que encaminha, para além do conflito social ao qual o filme se propõe a tratar, o lugar fundante da imagem, a um só tempo como vigilância

\footnotetext{
${ }^{15}$ Idem, ibidem.
} 
e espetáculo, na constituição do mundo contemporâneo e de nossa própria sensibilidade metropolitana.

A topografia da cidade é a paisagem e matriz privilegiada a partir da qual os documentaristas articulam seus dois eixos narrativos: a cronologia do seqüestro e a biografia de Sandro. Refletindo acerca das práticas de ocupar o espaço, De Certeau propõe que apreender a cidade do ponto mais alto possível remete ao prazer de vê-la em sua totalidade. Segundo o antropólogo, engendra-se aí um projeto que almeja "superar e articular as contradições urbanas", afastando-se dos comportamentos cotidianos e criando uma "ficção do saber" ${ }^{16}$ Nesse sentido, reforçando a estética do distanciamento, o travelling aéreo pontuará o documentário do início ao fim, retraçando desde o alto uma cartografia topográfica, conduzindo-nos a diferentes lugares da cidade que dizem respeito à trajetória do seqüestrador. Durante o percurso do filme, estaremos sempre alternando esses sobrevôos e mergulhos no Rio de Janeiro, conhecendo lugares e pessoas que tiveram relação na vida de Sandro, assistindo aos encontros do documentarista-câmera com seus entrevistados ou paralisados no Jardim Botânico, olhando o seqüestro pela visão dos envolvidos.

\footnotetext{
${ }^{16}$ DE CERTEAU, Michel. A invenção do cotidiano. v. 1. Artes de Fazer. Rio de Janeiro: Vozes, 1994. p. 172.
} 


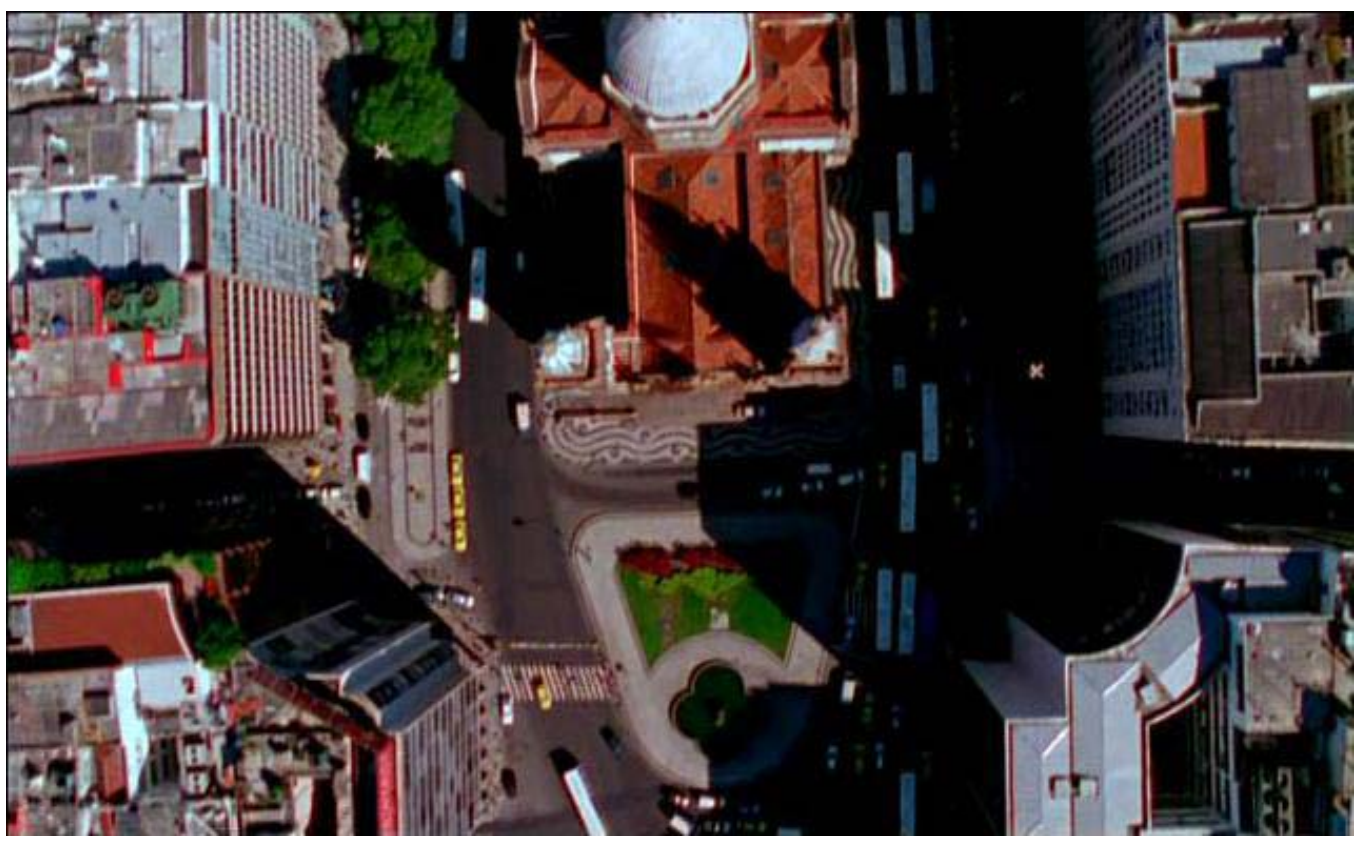

\subsection{Um filme de peregrinação}

Se Coutinho nos propôs um filme de visitas, em Ônibus 174 estamos todo o tempo peregrinando na cidade levados, geralmente, pelas falas das personagens ou por aquelas proferidas caoticamente por Sandro da janela do ônibus para as câmeras de televisão. São as falas que geralmente impulsionam a narrativa e criam um roteiro a partir do qual badalamos de um lugar a outro da capital carioca. Por esses agenciamentos é interessante observar que cidade recriada pelos diretores vai além do contexto ou do cenário onde a história acontece, ela traça uma geometria entre espaço e personagem inscrevendo um princípio de complementaridade, inter-relação e espelhamento entre eles. Sandro é recuperado em sua ausência pelos caminhos que trilhou na cidade, são seus percursos e peregrinações que atribuem sentido aos 
lugares que nos são apresentados de forma fragmentada.

Mesmo cercados de cuidados em sua aderência à “objetividade e verossimilhança", como endossou Padilha, são nas incursões cotidianas de Sandro que se abrem brechas à imaginação do espectador. Nos seus deslocamentos, em sua arte de "moldar percursos"17 e arquitetar uma narrativa espacial pela cidade, os documentaristas nos levam a perseguir imaginariamente as ruas da capital carioca.

A paisagem urbana é moldada no imaginário do desterro, das errâncias dos percursos atribuídos à figura de Sandro e nos lugares que marcaram sua vida na metrópole. Os locais por onde circulou, as situações vivenciadas, as pessoas que cruzou em suas baladas. Essas jornadas, todas tracejadas pelos planos aéreos, marcam os lugares de vivências e rituais de iniciação do seqüestrador na cidade: a casa materna no bairro da Boa Vista, onde presenciou o assassinato da mãe; o Meyer, sua iniciação nas ruas, a migração com outros companheiros para Copacabana, pois “tem dinheiro, tem comida e na zona sul eles passam menos fome que no subúrbio"18; a moradia nas calçadas da Igreja da Candelária, lugar de amizades e confronto com os policiais que realizam uma chacina que mata muitos de seus companheiros; a ponte perto do Teatro Ana Maria Clara, abrigo para os dias de frio; a PUC, no Jardim Botânico, onde é convidado para participar de um grupo de capoeira; o sinal de trânsito onde assalta um carro e é levado à Febem Niterói, onde fala à tia que quer recomeçar a vida; Nova Brasília onde cria um vínculo com uma senhora a quem chama de mãe e passa a viver, o seqüestro de um ônibus, novamente no Jardim Botânico, experiência derradeira.

${ }^{17}$ DE CERTEAU, Michel, op.cit., p.180. 
É, portanto, refazendo nas imagens essa via sacra que imaginamos como Sandro inventou sua maneira de estar na cidade e fez do mundo da rua, apesar de hostil e perverso, um espaço de sociabilidade, de movimento, de circulação de coisas e pessoas. Este contexto, mesmo em meio a ruínas, prenuncia mudança e faz contraponto ao lar de origem, ao seu mito de fundação que ele professa não aos seus iguais para quem, geralmente, constrói a imagem de uma pessoa calada (ele nunca falava de sua infância, diz a ex-menina de rua), mas à sua tia de Candelária a quem parecia ter uma maior abertura (ele sempre voltava à história que tinha visto sua mãe ser assassinada, conta ela).

\subsection{A cidade, Sandro, os meninos de rua e a mídia como personagens}

Essa visibilidade da cidade em Ônibus 174 sabemos, não é neutra nem inocente. Os diretores refazem sua sinfonia metropolitana em século XXI, evocando, desde a exacerbação do cenário urbano, a violência da capital carioca, privilegiando a linha narrativa de um seqüestro em espaço público, transformado em evento mídiatico, que começa durante o dia e termina, tragicamente, à noite com a morte de uma refém. Já ao início o documentário propõe ao espectador uma trama de personagens sendo a cidade, a um só tempo, o palco e a protagonista que contracena com todas as outras.

Esther Hamburger, que estuda as políticas de representação da cidade e suas

${ }^{18}$ Fala de Yonne Mello no filme. 
implicações no contexto brasileiro, afirma que Ônibus 174, para além de todas as afinidades narrativas que cultiva em relação a Notícias de uma guerra particular, traz um dado inovador ao documentário brasileiro: a mídia como personagem.

Os dois filmes expressam os princípios de representação adotados na nova fase do cinema brasileiro. A violência presente como alegoria no Cinema Novo, emerge com força nos marcos dos documentários na produção contemporânea. A violência aparece como força endêmica, que polariza disputas pelo controle da representação. Sintomaticamente Ônibus 174 introduziu mais um ator na cena tripartíade de Notícias: a própria tv, as câmeras, o jornalismo.19

As seqüências inicias tramam essa polifonia, apresentando as personagens e propondo desde ali a articulação que orientará o filme até o final. Leituras possibilitadas pelo agenciamento narrativo conferido na montagem e que acaba por costurar em um mesmo tecido a paisagem urbana, o trágico destino dos meninos de rua espelhados em Sandro, o seqüestro do qual foi protagonista, os passageiros, a polícia e a mídia; esses dois últimos mutuamente imbricados e atravessados em suas funções de vigilância e espetáculo nas metrópoles contemporâneas.

Ao início um longo travelling aéreo faz um passeio que começa no mar, peregrina pelas construções precárias das favelas, sobe o morro, descortina as zonas residenciais e chega ao Jardim Botânico, lugar do seqüestro. ${ }^{20} \mathrm{O}$ ritmo do passeio que parecia rasgar o mar pela velocidade, agora, em seu olhar sobre a cidade, é lento, sem pressa e sugere, pelo recorte e ponto de vista, o olhar da onisciência.

\footnotetext{
${ }^{19}$ HAMBURGER, Esther. Op.cit., p.202. Grifo meu.

20 Plano que evoca tanto Rio 40 graus, 1955, de Nelson Pereira dos Santos, como uma antiga vinheta da Rede Globo.
} 
A trilha investe na conformação de um clima dramático adensado pelos contrastes das rachaduras sociais que emergem nessa geografia e por vozes anônimas que impõem significados à ampla visão da cidade. Vozes que se tramam aos grandes planos aéreos da metrópole de pessoas que moram nas ruas, que falam seus nomes, mas não tem rostos. Elas contam os motivos que as levaram a procurar abrigo na desestabilidade das ruas, ambiguamente vista ora como uma possibilidade de amparo em relação às desestruturas do núcleo familiar, ora como revolta por perceber que enquanto dormem sob a marquise tem "um playbozinho, lá em cima, deitado numa cama e a gente aqui deitado no chão. (...) Quando cresce, já cresce revoltado."

O último depoimento é de alguém que fala de Sandro, chamando-lhe pelo apelido, "Mancha", estabelecendo desde aí um dos jogos narrativos que será reforçado ao longo do documentário, a sobreposição da figura do seqüestrador como porta-voz da trajetória social dos meninos de rua. $\mathrm{O}$ amigo diz que ele foi pra rua criança,

O Mancha, cara (...) não teve tempo de ter o amor de ninguém. Então a única coisa que ele aprendeu na rua foi sobreviver, Mano, foi o que nós todos aprendemos, a sobreviver por si próprios. Porque se eu for um menor de rua e tiver aqui sentado e não correr atrás, ninguém vai querer aparecer ali e dar uma comida, vai não! A gente tem que correr atrás mesmo.

A opção por essa estética documental de vozes invisíveis que emanam da cidade aderem, no percurso narrativo, à fala do antropólogo e ex-secretário de segurança do Rio de Janeiro, Luiz Eduardo Soares, que desenvolve a teoria da 
invisibilidade, usual nas ciências sociais quando se trata de analisar as discriminações socioculturais. Na visão do especialista, banalizamos esse outro com nossa indiferença e recusa em reconhecer nele algum valor. “Sandro é o exemplo dos meninos invisíveis que eventualmente emergem e tomam a cena e nos confrontam com a sua violência". O confronto viria, então, como uma atitude que busca o reconhecimento, uma forma de se fazer ver por uma sociedade perversa ao tratar suas desigualdades sociais. Reside aí, segundo Soares, um dos núcleos geradores da violência urbana:

A grande luta desses meninos é contra a invisibilidade. Nós não somos nada se ninguém nos olha, não reconhece o nosso valor, não preza a nossa existência, não diz a nós que nós temos algum valor, não devolve a nós a nossa imagem ungida de algum brilho, de alguma vitalidade, de algum reconhecimento. Estes meninos estão famintos de existência social. Famintos de reconhecimento.

Hipótese que nas opções narrativas acaba por espelhar os meninos e meninas de rua em Sandro, ele mesmo construído na realidade documental como um símbolo maior da fratura social do país, esboçando um destino trágico, comum àqueles que vivem à deriva nas grandes cidades brasileiras.

Apresentadas essas personagens, a cidade imantada de uma população anônima que habita as ruas da capital do Rio de Janeiro, o travelling aéreo prossegue e a trilha-tema do filme dá lugar a sirenes e ainda em off o policial chamado a conferir a ocorrência dará início à cronologia do seqüestro.

Eu tive notícia pelo rádio da viatura administrativa em que eu estava 
que o Bope estaria sendo acionado para uma ocorrência com refém no Jardim Botânico (...) e fui o primeiro a chegar no local.

Um plongée nos faz ver a viatura estacionada, no meio da rua, ao lado do ônibus parado. Um último depoimento, antes dos créditos iniciais, introduz a mídia como personagem fundamental nesse drama. O jornalista conta que começaram a ver as imagens captadas pelas câmeras de vigilância pública na redação do jornal e que "imediatamente toda a equipe foi pra lá", revelando a trama que se estabelece comumente entre controle, notícia e espetáculo características das cidades contemporâneas. Diga-se de passagem, também, esse agenciamento do comércio das imagens banalmente extraordinárias da violência são moedas correntes ao público brasileiro familiarizados com programas sensacionalistas que vendem as desestabilidades urbanas em registro conservador e preconceituoso. João Salles comenta que "a televisão, mesmo se está na favela no momento de alguma tragédia ou tiroteio, sempre está lá ao lado da polícia, ouvindo e contando a sua versão dos fatos" ${ }^{21}$ Reafirmando um caminho de mão dupla, as imagens captadas pela CET/RJ serão reiteradamente utilizadas no documentário que em sua reconstrução temporal mostra a cena, paulatinamente, sendo povoada por jornalistas, câmeras, fotógrafos. Uns filmam-se aos outros cada vez mais próximos do ônibus e da mira do seqüestrador, ávidos por captar as melhores imagens para suas empresas de notícias.

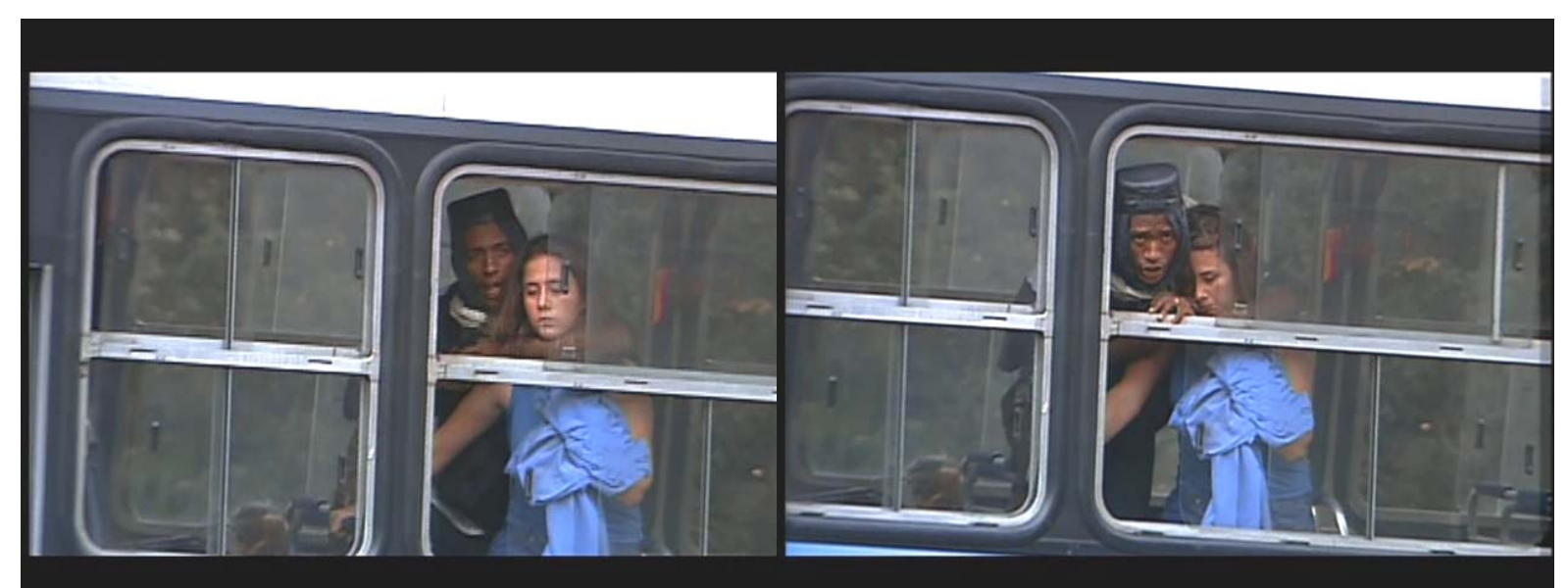


Sandro responde ao apelo midiático e joga com ele. Ao início do seqüestro preocupa-se em cobrir o rosto, aos poucos, na medida em que vê aumentar a presença das câmeras, coloca o rosto para fora da janela e passa a proferir discursos diretamente para elas. Na opinião de Padilha,

O filme deixa claro a ambigüidade do seqüestrador, que nos primeiros instantes se preocupa em fugir e não colocar mais os pés no inferno da prisão. À medida que aumenta o número de cinegrafistas e os flashes disparam em sua direção, ele prolonga o seqüestro, incitando a vontade de chamar a atenção .22

O despreparo da polícia aumenta a situação de vulnerabilidade e perigo dos profissionais da mídia que encontram-se em volta do ônibus, em pleno campo de batalha. Todos têm livre acesso, não há controle nem limites demarcando o território de ação policial. Hamburger é pontual ao observar que como personagem de um reality show Sandro "perversamente tomou a mídia como refém" 23 e a deixou paralisada.

São muitos os olhares em direção a Sandro. As câmeras de vigilância, sem a presença humana, que captam em imagens precárias, codificando na tela local, data e horário e aquelas das emissoras de televisão que espalham-se no território buscando

22 Cf. LAVIA, Jairo. As feridas abertas do Ônibus 174. Revistaparadoxo. Disponível em: <http:/ / www.revistaparadoxo.com> Acesso em: 9 maio 2005.

${ }^{23}$ HAMBURGER, Esther. Op. cit., p. 205. 
os melhores ângulos para registrar o acontecimento. Alguns cinegrafistas, podemos vê-los nas imagens, estão muito próximos do ônibus configurando um "olhar ameaçado", apontando, "de maneira indicial e reflexiva para o perigo mortal enfrentado", na definição de Vivian Sobchack, em suas "dez proposições sobre morte, representação e documentário. ${ }^{24}$ Contudo, a voracidade pelas imagens amenizava o clima da perigosa situação a qual se encontravam.

Com afinco Sandro cumpre a promessa que fez à senhora que o adotou de que um dia ela o veria na televisão fazendo sucesso e, efetivamente, esforça-se em desempenhar com maestria o papel de homem mau aterrorizando e fascinando a mídia ávida em registrar sua performance de diferentes pontos de vista, cada vez mais próximos. Aos berros, de forma confusa e urgente, vai retraçando sua história de vida jorrada pela janela para quem quisesse apanhar. E todos queriam divulgar, ao vivo, esses momentos que animavam o show da violência e da visibilidade.

(...) se liga só rapaziada da mesma forma que vocês é perverso eu também! Não sou de bobeira, não! Tá ligado? Não tenho medo de polícia não! O papo pode ficar sério mesmo! Pode olhar pra minha cara mesmo! Às 6 horas ela vai morrer! Pode filmar todo mundo mesmo!

Os depoimentos das reféns nos levam para dentro do ônibus e revelam que, em muitos momentos, Sandro foi também diretor de cena, orquestrando gritos e reações para simular um desespero maior do que aquele instaurado sob a ameaça do seu revólver. Fingiu matar uma das reféns às 18 horas, conforme prometido,

\footnotetext{
${ }^{24}$ SOBCHACK, Vivian. Inscrevendo o espaço ético: dez proposições sobre a morte. In: RAMOS,
} Fernão (Org.). Teoria contemporânea do cinema. v. I. São Paulo: Senac, 2005. p. 150. 
anunciado aos gritos e escrito com batom na janela do ônibus por uma das passageiras. A mesma que simula sua própria morte.

As imagens aéreas nos levam às torres retransmissoras que enfeitam os morros do Rio de Janeiro. Uma das reféns, que tentou estabelecer vínculos com o seqüestrador, afirma pontualmente "eu acho que a televisão permitiu que ele se sentisse poderoso à medida que ele sabia que estava sendo filmado e queria ser filmado". Percepção reforçada por um policial "a mídia é algo que traz confiança ao seqüestrador. É a certeza de que não vai ser executado ali". Para o antropólogo, que também profere sua fala em off sob as imagens das torres retransmissoras, esse foi um momento que Sandro impôs aos espectadores sua visibilidade, perdida poucas horas depois com seu assassinato pelas mãos dos policiais.

Mas, certamente, não era somente Sandro que tinha consciência das câmeras. Excetuando os reféns dentro do ônibus que estavam em pânico, os policiais (incluindo aquele que, num lance final, erra o tiro direcionado ao seqüestrador e mata a refém diante das câmeras) e a própria mídia, personagem de si mesma, sabiam estar não somente executando seu trabalho, como também agindo diante das câmeras, até mesmo as de vigilância pública. Todos, de certa forma, atuavam e performatizavam suas atuações públicas. Da mesma maneira, posteriormente, as personagens convocadas a participar do documentário estavam predispostas a integrar o jogo e contracenar com os diretores, segundo os pactos e regras que regem a produção audiovisual.

Nesse sentido, a auto-mise-en-scène da mídia, que nos revela Ônibus 174, esse se filmar a si mesma enquanto atua na caça à melhor imagem, nos revela ainda uma 
outra guerra deflagrada no espaço público "a guerra suave e fria da informação", como diz Bonitzer refletindo acerca da produção de imagens contemporâneas, "subimagens" 25 que exploram a miséria, a violência, a tortura e todo o tipo de obscenidade que possa reverter em fluxos de visibilidade vendáveis.

Porém, percebemos que a mídia é a grande personagem desse filme, não só porque ficou paralisada em Sandro e porque as imagens que produziu do seqüestro e de si mesma em ação foram o centro da realização do filme de Padilha e Lacerda. Sem ela esse seqüestro seria mais um assalto efêmero e banal como tantos outros que acontecem diariamente nas ruas das cidades brasileiras. Ela adquire seu estatuto de protagonista, sobretudo por ser o maior emblema do homem urbano contemporâneo, seja ele quem for: Sandro ou mesmo essa instância maior que, falando ao celular com o Coronel que comandava a operação, não permitiu que "os miolos do seqüestrador fossem estourados diante das câmeras à luz do dia", como afirmou o ex-policial do Bope em sua entrevista no documentário. Instância que poderia ser o governador, os patrocinadores do horário, os donos das emissoras, enfim, os invisíveis produtores da visibilidade. A mídia é uma das grandes personagens desse filme, pois não se pode pensar a cidade ou a paisagem urbana excluindo a sua presença, sem os intensos e ininterruptos fluxos de imagens que atravessam nosso imaginário, nos conectam ao mundo e moldam nossa sensibilidade.

No artigo travelling de Kappo, Serge Daney ${ }^{26}$ retoma a crítica e a expressão de Jacques Rivette acerca do movimento de câmera executado por Gillo Pontecorvo em seu filme Kappo. Na visão de Rivette, o diretor produz uma imagem abjeta ao

\footnotetext{
${ }^{25}$ BONITZER, Pascal. La surimage. Cahiers du cinéma, Paris, n. 270, sept.-oct. 1976.

26DANEY, Serge. Perseverance: entretien avec Serge Toubiana. Paris: P.O.L., 2003.
} 
estetizar o suicídio de Riva, personagem que morre eletrocutado jogando-se nas cercas de um campo de concentração nazista. “Um simples movimento de câmera poderia ser o movimento a não se fazer", afirma categoricamente Rivette. ${ }^{27}$ Há outras formas de mostrar a dor do mundo, nos diz o cineasta-crítico, ainda que seja a de sugeri-la ou mesmo evocá-la pela ausência, resguardando-a em sua própria singularidade.

Hoje em dia, diz Daney, a violência é a violência da forma, a espetacularização da miséria, da exclusão, das guerras urbanas, etc., engendradas nas mais diversas maneiras de produções midiáticas, sendo a televisão o lugar privilegiado onde se confiscam as dores do mundo por um objetivo mercantil. É nesse registro que se movimenta Ônibus 174, que a um só tempo se pretende crítico, mas adere à lógica do mercado televisual, em chave de um "humanismo lamuriante" 28 , inscrevendo o fenômeno urbano brasileiro no show dos clichês da visibilidade (abjeta).

Fazer um filme é mostrar certas coisas, é ao mesmo tempo e pela mesma operação mostrá-las por um certo viés: estes dois atos estão rigorosamente indissociáveis. ${ }^{29}$

Em nome de um documentário social - distanciado e objetivo - que repense as assimetrias e fraturas que assolam as cidades brasileiras, os documentaristas lançam mão das mais redutoras técnicas do audiovisual e de um amplo repertório para arrancar lágrimas do espectador.

${ }^{27}$ RIVETTE, Jacques. Cahiers du cinéma, Paris, n. 170, jun. 1961.

${ }_{28}^{8}$ BONITZER, Pascal. Op. cit.

${ }^{29}$ RIVETTE, Jacques. Cahiers du cinéma, Paris, n. 170, jun. 1961. 


\section{RUA DE MÃO DUPLA: A SOCIABILIDADE ÀS AVESSAS E A CIDADE DO OUTRO}

O dispositivo de realização desenvolvido por Cao Guimarães para Rua de mão dupla é aparentemente simples: pessoas que não se conhecem trocam de casa por 24 horas, portando uma câmera de vídeo e com total liberdade para gravar o que quiserem uma na casa da outra. Ao final desse período, cada participante tenta traçar uma imagem mental do outro, imaginar suas características e arriscar se teriam ou não afinidades com o morador ausente.

O filme é composto por três blocos com diferentes duplas. Rafael Soares, produtor musical, 25 anos e Eliane Lacerda, oficial de justiça, 36; Paulo Dimas, arquiteto, 43 anos e Mauro Nevenschwander, construtor, 60 anos; Eliane Marta, escritora, 55 anos e Roberto Soares, poeta, 49 anos. No decorrer das imagens e, sobretudo, dos depoimentos colhidos pelo diretor Cao Guimarães, vamos percebendo as nuances de estilos de vida, classe social e referências culturais de cada um. Percebemos também, através da fala de algumas personagens, que o projeto foi realizado em Belo Horizonte, apesar dessa informação não ser enfatizada em 
nenhum momento pelo realizador.

As seqüências de 20, 25 e 30 minutos, respectivamente, iniciam com uma tela preta com o número do bloco escrito em romano e, em seguida, lê-se o nome completo dos participantes e as regras do jogo: eles não se conhecem e trocam de casas por 24 horas, cada um portando uma câmera de vídeo. É somente após alguns segundos de já estarmos vendo as imagens que, ao pé do quadro, leremos o nome dos autores das imagens, suas idades e profissões.

Realizado originalmente para a $25^{\mathrm{a}}$ Bienal Internacional de São Paulo, em 2002, que teve como tema Iconografias Metropolitanas, ao ser transferido para uma única tela Rua de mão dupla guarda as características do espírito que o originou: a de um cinema expandido que implode o espaço fílmico propondo uma leitura diferenciada e plural. A tela é permanentemente dividida ao meio de maneira que estamos sempre vendo o registro de duas casas paralelamente ${ }^{1}$. Uma narrativa de mão dupla. Duas estéticas engendrando uma terceira pela composição da montagem.

A disposição gráfica da apresentação faz com que os dois quadros estejam dispostos entre duas faixas pretas, acima e abaixo, e que vazem as margens laterais da tela. Também a tênue borda que separa os quadros provoca uma estreita proximidade e faz com que a fronteira entre eles se fragilize e crie a sensação de que os espaços se interpenetram formando um só. Um espaço invadindo o outro numa proposta de mistura e hibridização acentuada pela estética de captação dos participantes. Imagens caseiras, precárias, instáveis, desenquadradas e que

\footnotetext{
${ }^{1}$ Gostaria de observar que o recurso da multitela é bastante explorado nas narrativas audiovisuais. Contudo, poucos realizadores o mantém como estrutura durante toda a narrativa. Nessa chave, ainda que em registros e propostas diferenciadas, destacaríamos dois trabalhos: o projeto videográfico Parabolic people, 1991, de Sandra Kogut e a ficção Timecode, 2000, de Mike Figgis.
} 
predominantemente privilegiam os planos fechados na busca dos detalhes que segredam as características do outro.
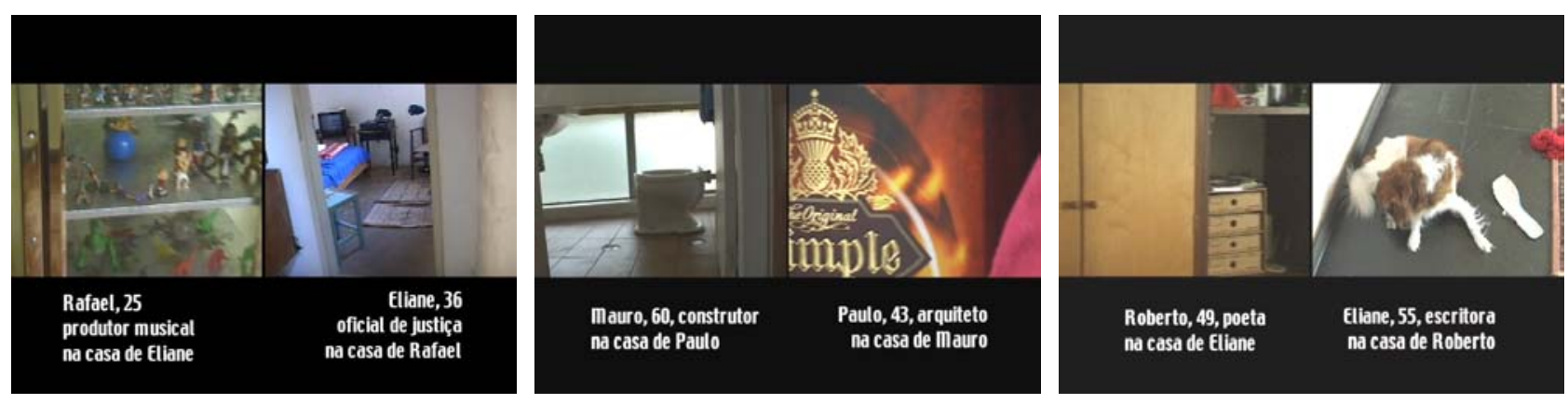

Seguindo a lógica da concomitância de apresentações, ao final de cada seqüência as imagens dos espaços e objetos se corporificam na presença dos seus autores/habitantes, que entram em cena para traçar o retrato-falado do morador ausente, comunicar suas impressões do espaço do outro e o sentimento da experiência de ser um estrangeiro em sua própria cidade. É a primeira vez que veremos as personagens, com exceção, é claro, dos momentos em que elas se incluíram nas imagens que filmavam, como é o caso recorrente de Rafael. Nessa diagramação a dupla aparece ao mesmo tempo na tela dividida ao meio e enquanto uma fala, arriscando suas hipóteses sobre o anfitrião ausente, o espectador a vê no quadro ao lado.

Com movimentos mínimos, sentada, aquela que está sendo descrita permanece em estado de escuta do seu retrato falado. Ela olha pra frente, para a câmera que, em última instância, é nada mais do que nós, o nosso corpo e os nossos olhos de espectadores duplamente seqüestrados por aquele que fala e por aquele que escuta. Ambos roubam, com sua frontalidade, nossa atenção, centro desse triângulo. 
Como o olhar do pintor de Velásquez, narrado sob a ótica de Michael Foucault², essas personagens nos têm como ponto de fuga do seu olhar e solicitam o nosso espaço, "esse espaço em que estamos, esse espaço que somos" representação fílmica.

Os depoimentos, colhidos ao final das 24 horas pelo diretor, foram captados na casa registrada. Na casa do outro. Já o anfitrião escuta o veredito de seu convidado, em sua própria casa. Isso faz com que nesse momento haja na tela uma simultaneidade dos espaços sem, obrigatoriamente, uma equivalência dos ambientes, embora isso possa acontecer, intensificando a sensação de estranheza no espectador. Rafael fala de suas impressões sobre Eliane Lacerda na sala da casa dela, sentado na cadeira e no cenário em que ela o escuta. Da mesma forma Paulo desenha o "retrato falado" de Eliane Marta, no mesmo sofá em que ela aparece sentada no quadro ao lado.

Simultaneidades que provocam ainda mais a atenção e a imaginação do espectador que trabalha ativamente nas possibilidades de leitura das imagens engendrando desde aí a noção de jogo ${ }^{4}$, comparando o que está sendo dito com a figura do outro, ou mesmo contrapondo as duas falas e vendo como as estranhezas de um em relação ao outro acabam por ser, não poucas vezes, opostos complementares (aquele que é descrito como desorganizado, observa a organização da anfitriã; o que notou a falta de mulheres na casa do morador ausente é enquadrado como um macho por seu visitante; aquele que é definido como

\footnotetext{
2 FOUCAULT, Michel. As palavras e as coisas: uma arqueologia das ciências humanas. Lisboa: Edições 70, 1988.

${ }^{3}$ Idem. Ibidem. p.60. Grifo nosso.

${ }^{4}$ Consuelo Lins propõe a noção de jogo na explicitação das regras do dispositivo de filmagem. Cf. em
} 
desprovido, sensibiliza-se à abundância do mundo do outro).

Tornando ainda mais complexa a interação mental e corporal do espectador ${ }^{5}$, podemos observar também quais elementos o visitante privilegiou, entre as imagens que gravou, para articular o seu discurso sobre o outro e o quanto elas acabam por falar dele próprio. Migliorin ${ }^{6}$ propõe que nós espectadores temos mais informações do que os participantes do jogo e "ficamos constantemente comparando nossas leituras com as que estão no filme". Porém, podemos pensar também que temos informações diferenciadas uns dos outros e que até mesmo o arquiteto desse dispositivo que, a princípio, teria a totalidade das informações, acaba por ser engolido pelas múltiplas possibilidades semânticas advindas das diferentes combinações possíveis.

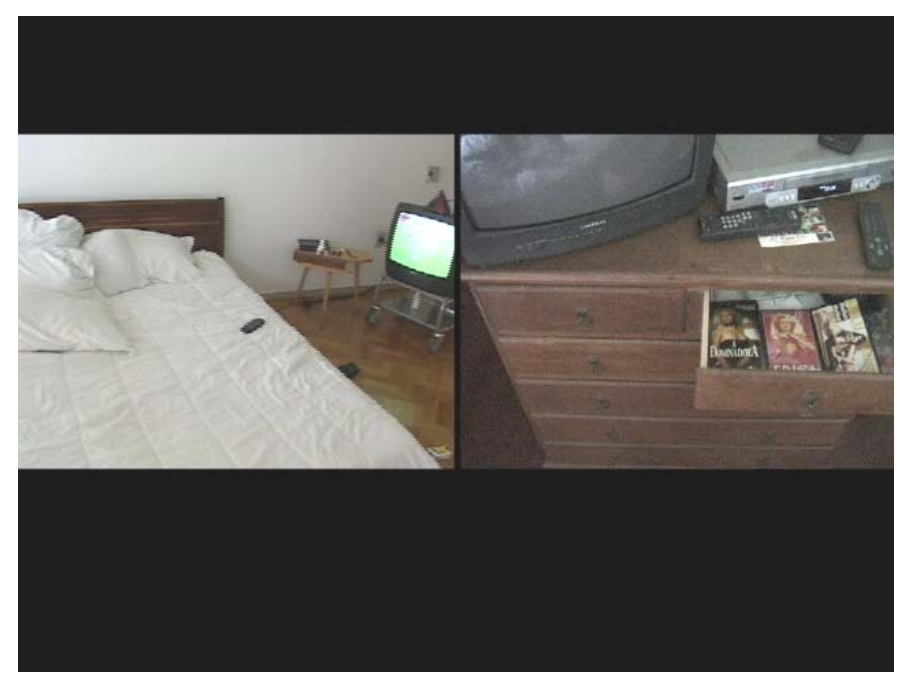

Assim, a cada bloco de imagens há diferentes autorias que se dão a ver: aquela das personagens-convidadas interferindo e construindo uma narrativa própria no

Rua de mão dupla: documentário e arte contemporânea. Disponível em:
<http://www.videobrasil.org.br/ffdossier/Ruademaodupla_ConsueloLins.pdf > 
interior das casas, a do diretor que, além de gravar os depoimentos, propõe o agenciamento narrativo da montagem e a nossa de espectadores diante das múltiplas leituras que a experiência de assistir e se engajar às estratégias do dispositivo adotado por Cao Guimarães na realização de Rua de mão dupla possibilitam.

Por esses fatores a experiência de assistir Rua de mão dupla traz a desestabilização do lugar e do olhar do espectador levado a acompanhar não só a narrativa de espaços de ausência da figura humana, como também a simultaneidade dos relatos apresentados em registro duplo na tela, sacudindo nosso habitual estado de abandono e passividade de consumidores de imagens.

Deslocamentos que inscrevem as imagens sob o signo do fora de lugar e do estranhamento. Estranhamento de não estar no seu lugar próprio, estranhamento do outro, da vida do outro, da ordenação de mundo que ele coloca no seu recanto mais íntimo, na sua casa, agora devassada na aderência ao pacto do jogo documental. Um pacto que se trama na ausência do morador e no olhar fílmico do inquilinotemporário que exerce a um só tempo uma autovigilância e uma auto-mise-en-scène, pois tem consciência que sua solidão será partilhada em um primeiro momento com o diretor a quem entregará suas imagens e com o público por onde a obra irá circular posteriormente. "As imagens acabam sendo fruto deste agenciamento entre um eu privado que exerce seu voyerismo solitário e um eu público que filma para o outro"7.

Podemos pensar também que em seus dispositivos de interação Cao Guimarães atua em registro misto. Por um lado, entrega a câmera às personagens possibilitando que elas realizem grande parte das imagens do documentário. Por 
outro, recolhe seus depoimentos para que a experiência se complete, para que elas possam expressar suas impressões do outro e relatar a experiência de ser um estrangeiro em sua própria cidade.

Mimetizando-se à filosofia da ausência implícita na proposta de realização, o diretor permanece distante nesse contato e borra todo e qualquer vestígio de sua presença no espaço narrativo, perpetuando o efeito de solidão ao qual suas personagens estão condicionadas. Em chave diferenciada àquela que vimos em Ônibus 174, estabelece uma distância entre ele e suas personagens, mas longe do efeito de objetividade que Padilha e Lacerda imprimem em sua narrativa. Aqui, o encontro do documentarista com as personagens vem atravessado pelas fabulações delas acerca do outro, esse outro imaginado que lhes possibilitou viverem uma sociabilidade às avessas, uma sociabilidade ausente onde interagiram e contracenaram com um interlocutor erigido desde as suas projeções imaginárias. Nesse sentido, percebemos que ambos dispositivos de interação: a personagemcâmera na casa do anfitrião ausente e os depoimentos recolhidos pelo diretor, filiamse a um regime cristal flutuando na imprecisão, nas hipóteses acerca do outro e do si mesmo e afirmando a narrativa como um campo imaginário. Lugar onde acena ao estatuto apontado por Edifício Master e distancia-se radicalmente de Ônibus 174.

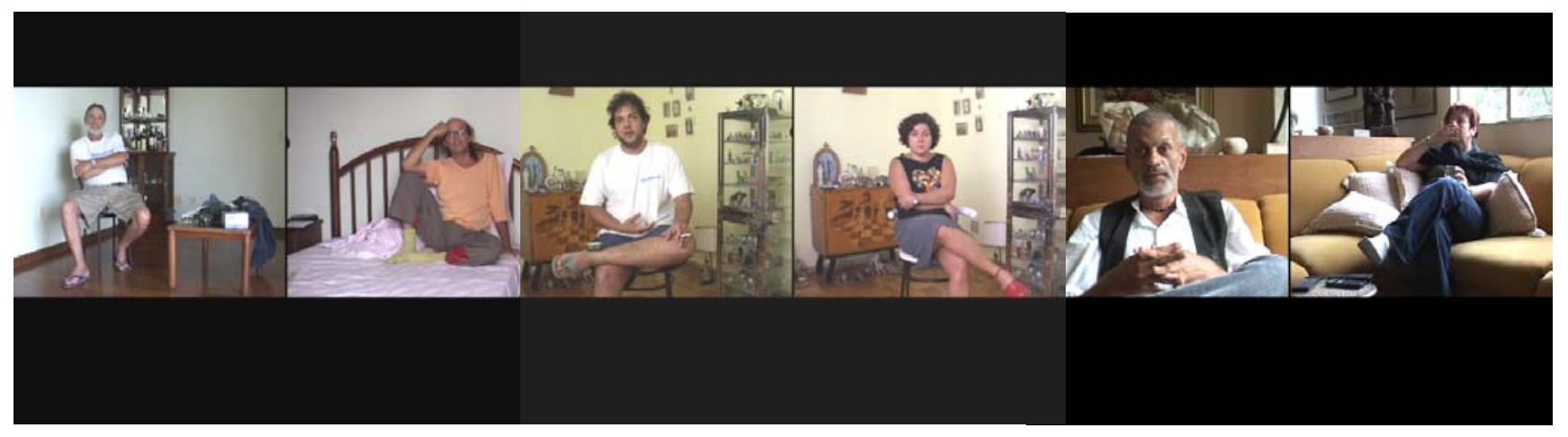




\subsection{A cidade interior}

Se podemos pensar em Edifício Master como um filme de visitas, onde estamos constantemente perambulando pelo prédio com Coutinho e sendo recepcionado pelos moradores nos seus apartamentos, em Rua de mão dupla, apesar de entrarmos nessas casas alheias, não há ninguém para nos receber. A ausência e retardamento da aparição da figura humana no campo de visão provoca uma sensação de invasão (consentida) de privacidade, de um voyeurismo proposto pelo realizador, aceito pelos participantes do jogo documental e endossado pela cumplicidade do olhar do espectador.

Como no filme de Coutinho, Rua de mão dupla constrói a tensão entre a cidade off e sua presença sugerida tanto pelo nome do documentário, como também pelos planos de paisagem captados através das janelas por duas das três duplas. Em Edifício Master, contudo, havia um movimento centrífugo. A pulsação caótica da urbe contaminava nos depoimentos das personagens coutinianas e até mesmo as imagens captadas no interior do prédio, forçavam as bordas do quadro em direção ao exterior. No documentário de Cao Guimarães, ao contrario, o movimento é centrípeto e até mesmo as imagens da rua serão revertidas à construção desse outro, dessa corporeidade que domina o ambiente em suas ausência. Exemplo pontual na segunda dupla.

Tanto Mauro, o construtor, como o arquiteto Paulo, moram em andares altos e 
aproveitam a vista da rua para mapear, ou antes "estranhar", um o estatuto social do outro através dos respectivos ambientes urbanos onde estão localizados, bem como da própria construção, dos seus apartamentos. Mauro revela sutilmente a paisagem da casa de Paulo a partir dos vidros inferiores da janela da sala e aproveita para dizer que aquele é um dos prédios mais chiques de Belo Horizonte, localizado na praça Liberdade. Mais tarde fará severas críticas àquele tipo de "construção moderna". Paulo, por sua vez, aproxima-se da janela, brinca com a tela de proteção, e explora, em diferentes planos, a vista do que viria a denominar como um "bairro classe média, um prédio classe média, de revestimento classe média de média".

A rua também estará presente nas captações do poeta Roberto Soares e da escritora Eliane Marta que irão aderir, como veremos, de forma simetricamente oposta à experiência documental proposta por Cao Guimarães. Apesar de morarem em ambientes que apontam dimensões diferentes à vida social de cada um, as paisagens de seus apartamentos evocam situações de vizinhança. Eliane Marta mostra em diferentes momentos as partidas de futebol que acontecem em um campo em frente à casa que habita temporariamente. Ela também se detém no céu, nas casinhas em volta, no movimento da rua. Em algumas ocasiões aproveita para fazer comentários, muitos deles em tom de crônica cotidiana do seu próprio olhar, em uma espécie de livre interpretação daquilo que vê. Roberto, por sua vez, observa a conversa entre uma senhora bem

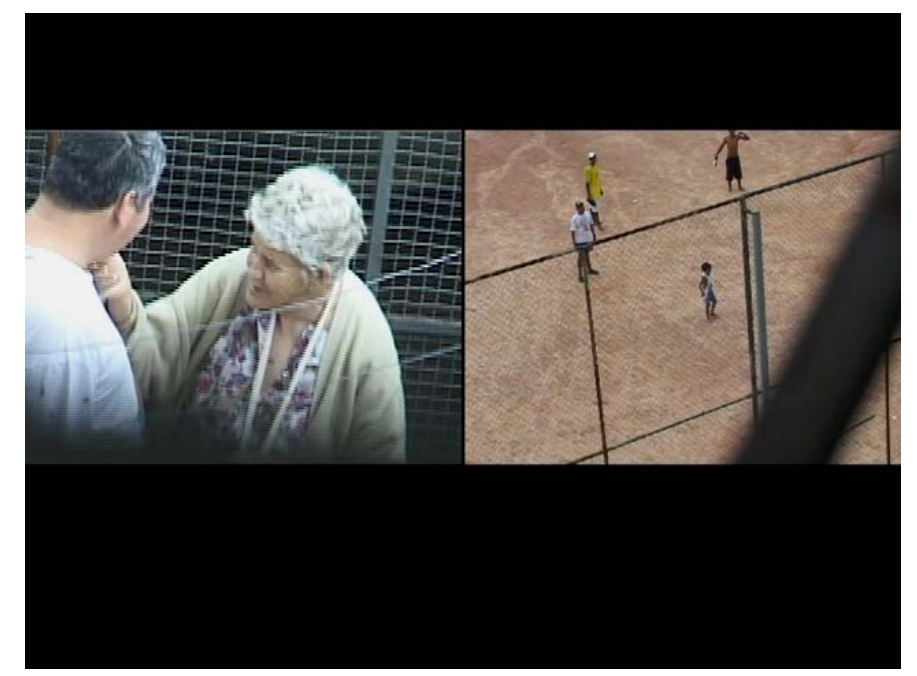


velhinha e um rapaz de meia idade. O pátio da casa onde estão e as roupas que usam denotam uma situação de vida modesta e, de alguma forma, casam com a paisagem que Eliane registra no seu ambiente. Ao contrario da escritora, Roberto permanece em silêncio, deixando-se falar, nesse momento, pelas imagens que registra.

Podemos pensar, contudo, que se em Edifício Master a cidade foi digerida e fabulada pelos moradores do prédio, em Rua de mão dupla ela contamina o próprio interior das casas e dos objetos rastreados pelas personagens-câmeras em seus "relatos do espaço da cultura cotidiana". 8 São fragmentos de cotidianidades que emergem nessas imagens onde tudo aponta para um estilo de vida iminentemente urbano, incluindo aí o próprio dispositivo de filmagem que se aproxima dos reallitys shows em chave de trocas de casas.

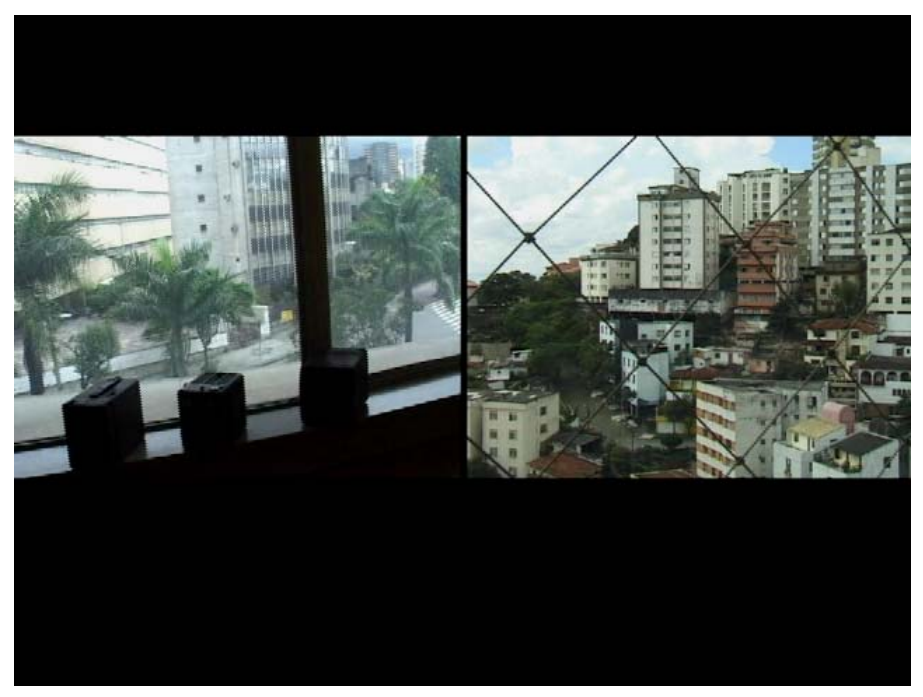

Diferentes elementos tramam-se nesse quadro do outro e do si mesmo: a maneira que as pessoas têm de organizar sua própria casa, a forma que elegem para gravar o espaço do outro, a performance de apresentar suas conclusões, a maneira de falar, bem como o que escolhem dizer e a auto-mise-en-scène ao simularem um estado 
de escuta (na tela ao lado) estão marcadas por suas personalidades urbanas. De maneira emblemática, o estilo de vida traduzido pelo espaço da casa acaba por configurar uma visibilidade que permite arriscar não só uma interpretação do outro, como também de uma certa personalidade dos habitantes da cidade, inscrevendo a cidade nos gestos, nos corpos, nos espaços e objetos.

As paisagens internas dos apartamentos, rastreados pelos olhares-câmeras, bifurcam-se na tela e vemos, concomitantemente, a casa de um através do olharcâmera do outro e vice-versa. E essa simultaneidade de visões que, a princípio, propõe o espaço de um mostrado no gesto do outro (objeto-de investigação em uma tela e sujeito-da-observação-câmera em outra) também sinaliza temporalidades distintas: aquela inscrita nas coisas, que evoca a memória dos objetos da casa, e a temporalidade inscrita no gesto do sujeito que filma e imprime ordem e ritmo pessoal a uma situação absolutamente impessoal (estar e filmar na casa de um anfitrião ausente).

Assim, os espaços interiores da intimidade da casa são traduzidos por temporalidades dos gestos enunciativos do estranho, do forasteiro, daquele que vem de fora e transforma o seu olhar-câmera em investigação, em busca de indícios na construção do mapa mental do anfitrião. Construção feita no tempo, no ritmo e na estética do cinegrafista (amador) que nos propõe seu olhar de investigador nos objetos, rastros e vestígios deixados pelo morador ausente. Proposta que ao mesmo tempo em que nos leva à descoberta desse novo mundo que se oferece a olhar, nos revela um outro através das escolhas e da maneira como o cinegrafista constrói seu olhar-câmera. A um só tempo aquele que olha é olhado e uma outra leitura possível é perceber como olha (estilística e conceitualmente) o outro, aquele que pertence à

${ }^{8}$ Cf. expressão em DE CERTEAU. Op.cit. p. 207. 
intimidade da tela ao lado.

(...) os participantes inserem suas personalidades (através de sua perspectiva) na personalidade da pessoa ausente. Solidões se confundem no fluxo do olhar e ser olhado, na presença ausente e na ausente presença, na identificação e diferenciação. ${ }^{9}$

Desse modo, Rua de mão dupla sugere uma cidade fabulada de dentro, mas aqui diferente de centrar-se na palavra, como em Edifício Master, a fabulação desenvolve-se é regida pela ação e gestualidades das personagens, instaurando outras formas de narrar. Nessa dramaturgia formalista a fala do gesto fílmico percorre as superfícies e a "imagem da casa se transforma na topografia da intimidade do outro". 10

É nesse sentido que essas instâncias de fabulações abrigam as personagens. Ou seja, em Rua de mão dupla as personagens documentais estão, antes de tudo, na estética de captação videográfica do participante estrangeiro, nas imagens e sons que produz e em como os registra, assim como na própria casa das coisas: nas gavetas, nos cofres, nos armários. ${ }^{11}$

O espaço transformado em tempo de ponto-de-vista e em tempo de percurso do narrador que concomitantemente peregrina pela casa e inventa-lhe uma geografia nas imagens que escolhe captar. De alguma maneira podemos pensar que essa é uma peculiaridade de Rua de mão dupla e uma inovação radical no documentário em termos formais: esse espaço transformado em tempo (de olhar, investigar, percorrer

\footnotetext{
${ }^{9}$ Contracapa do DVD Rua de mão dupla.

${ }^{10}$ BACHELARD, Gaston. A poética do espaço. In: Os pensadores. São Paulo: Abril Cultural, 1978. p.196.

${ }^{11}$ Idem. Ibidem. p. 197.
} 
as superfícies da casa e dos objetos) rouba, por alguns momentos, o lugar da personagem mimetizada pelo gesto cinematográfico que rastreia vestígios e traços do habitante daquele lugar. Assim, nessa perspectiva de privilegiar a imagem do espaço e das coisas dentro dele, há um dilatamento do tempo da apresentação dos corpos das personagens, o que só vai acontecer ao final de cada longa seqüência, quando já conhecemos seus estilos de registros com a câmera, os objetos que os participantes elegeram para construir sua "imagem mental" do morador ausente, bem como pela intimidade da casa de um vista pelo olhar do outro. "Um de olho no outro", como diz a capa da revista que Paulo (o arquiteto) grava com diferentes enquadramentos na casa de Mauro (o construtor).

Quando, contudo, chegamos a visualizar suas figuras, seu corpos, seus gestos, suas maneiras de vestir e as texturas de suas vozes; quando visualizarmos seu olhar e “o espaço em que estão e o espaço que são", como diria Foucault, as personagens não falarão de si mesmas, como convém à tradição documental, mas do outro, fabulando a imagem que formaram dele a partir da experiência vivida em sua casa.

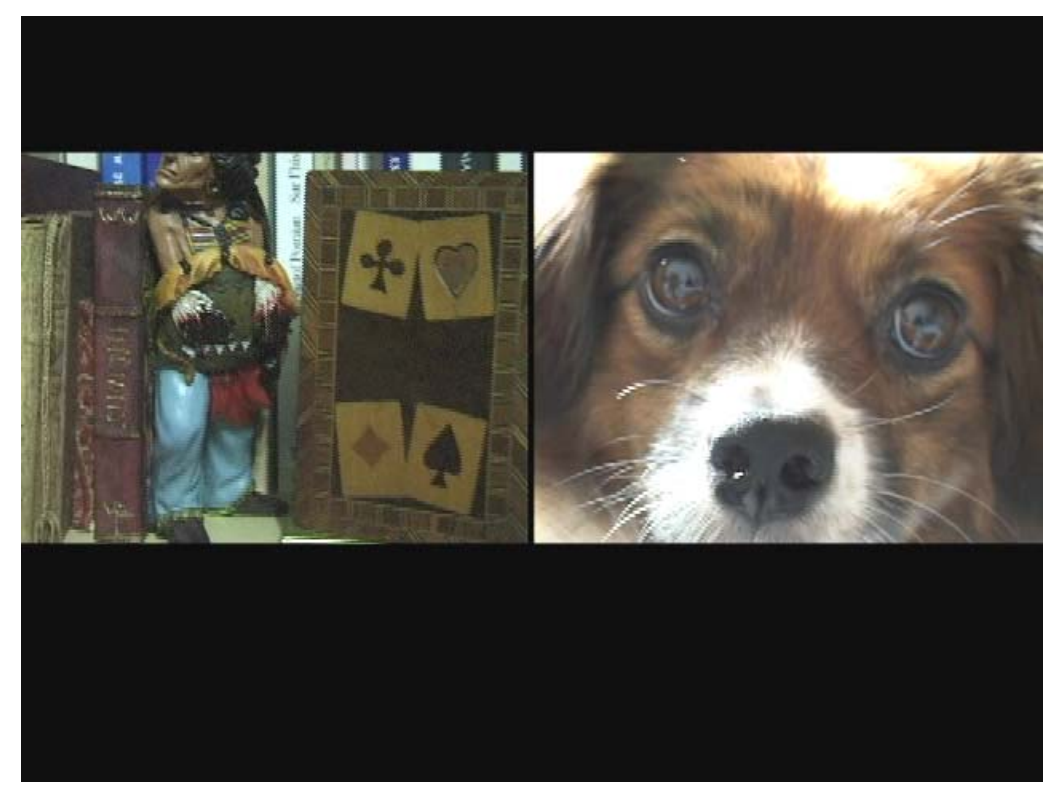




\subsection{Um filme de espelhamentos}

Nesse percurso narrativo onde o outro é o centro da atenção e do discurso, é interessante a maneira como, clandestinamente, acaba por se construir uma representação (estética) do si mesmo. Consuelo Lins observa que Rua de mão dupla "retoma a questão do outro, a quem o filme é dedicado, mas subverte essa tradição com instrumentos de práticas artísticas contemporâneas". Por esses caminhos "as querelas em torno da 'voz do outro' que atravessam a história do documentário" sofrem um deslocamento e o que podemos assistir é a carga de "exposição de si" contida em imagens e depoimentos teoricamente "sobre os outros". ${ }^{12}$ Nessas superfícies sensíveis ${ }^{13}$ é que se mostram as identidades e personalidades urbanas dos participantes de Rua de mão dupla.

Talvez essa seja outra grande contribuição de Cao Guimarães à reflexão documental ao optar por esse dispositivo ${ }^{14}$ de filmagem onde o centro de interesse é a busca da construção da imagem do outro: escancarar que filmar o outro é também se mostrar a si mesmo e com isso levar à reflexão do quanto o documentarista reproduz de si nas imagens que ele constrói para documentar o mundo e, da mesma maneira, o papel da imaginação nas inscrições das representações audiovisuais urbanas. Ou, como coloca Comolli15: “filmar uma cidade recoloca (cruamente) a

\footnotetext{
12 Op.cit. p. 1. Grifo nosso.

13 COMOLLI. 1997, p.156. Grifo nosso.

14 LINS, Consuelo; MIGLIORIN, César. Op.cit.

15 Idem. Ibidem. p.166. Grifo nosso.
} 
questão do sentido: reprodução de si? Produção do outro?".

Bem a propósito poderíamos pensar que o dispositivo de realização de $R u a$ de mão dupla acaba por expor o si mesmo com tanta intensidade que aciona, às avessas, um estilo de etnografia doméstica: “Uma forma de auto-retrato em que o self está em estreita ligação com seu outro familiar"16 provocando, nessa alteridade, um jogo de espelhamentos onde o self requer o outro e o outro refrata o self 17 . Indo por essa direção podemos pensar que as imagens em Rua de mão dupla flertam com as narrativas da subjetividade no sentido de promover para além do discurso sobre o outro um “exercício de auto-expressão" ${ }^{18}$

A ausência de qualquer outro interlocutor, a solidão na qual se encontra o participante do jogo documental, intensifica a auto-expressão que se manifesta, por um lado, pela "arte da palavra"19 (que adensa a personagem "invisível em cena" 20) no momento das gravações dos interiores das casas. Palavras que nas formas do dizer adquirem tons de balbucios, pensamentos íntimos, comentários e narração. Mauro organiza sua fala dirigindo-se a um espectador ausente em estilo afinado com apresentadores de televisão. Peregrina pela casa de Paulo em um travelling estável, fazendo comentários sobre o espaço, a arquitetura, os móveis e adereços:

\footnotetext{
${ }^{16}$ REANOV, Michael. Investigando o sujeito: uma introdução. In: LABAKI, Amir; MOURÃO, Dora. O cinema do real. São Paulo: Cosac Naif, 2005. p. 238. Grifo nosso.

${ }^{17}$ Idem. Ibidem. Grifo nosso.

${ }^{18}$ Op.cit., p.246.

${ }^{19}$ ROTH, Laurent. A câmera DV: órgão de um corpo em mutação. In: LABAKI, Amir; MOURÃO, Dora. O cinema do real. São Paulo: Cosac Naif, 2005. Roth vê o cinema praticado com as câmeras DVs como "a arte da mão e da palavra". Arte da palavra "porque acredito que a grande evolução trazida por essa câmera (...) está na palavra, pela facilidade de se registrar o som",p.35.

${ }^{20}$ BONITZER, Pascal. Peinture et cinema: Décadrages. Paris: Cahiers du cinema/Editions de l'etoile, 1995, p.20. “...comentário (ou o invisível colocado em cena)" é observação de Bonitzer acerca da voz off de documentários que dirigiam o olhar do espectador a um sentido unívoco e preconceituoso na leitura das imagens documentais.
} 
Bem, eu estou entrando na casa do meu hóspede; hóspede não, anfitrião. Casa completamente louca. Dá pra perceber... esse louco que eu falo no bom sentido, não é. Tem muita arte, muita coisa bonita né? Como dá pra perceber é um dos prédios mais chiques de Belo Horizonte, Edifício Niemayer, aqui na Praça da Liberdade e pelo tipo de móveis, e dá pra perceber tratar-se de uma pessoa de muito bom gosto, talvez um arquiteto.

Eliane Marta, escritora, dá um tom de ensaio às suas percepções que ora se dirigem a reportar, com comentários pessoais, aquilo que vê, ora assumem tons de monólogo interior:

Isso parece uma calcinha. Quando entrei vi essa coisa vermelha jogada no chão e pensei que fosse uma calcinha e fiquei me indagando se aquilo era um sapato de homem ou um sapato de mulher (aproxima a zoom do sapato). Mesmo que já soubesse que era a casa de um homem eu fiquei procurando traços de mulher. Não importa se é de homem ou de mulher. É um sapato. Ta aí.

Bem a propósito, Comolli comenta que quando o enunciador não sabe muito bem a quem e para quem ele se anuncia, ele só pode se dirigir a si próprio, tornandose o seu próprio auditor e, nesse sentido, que sem uma referência segura sobre um ouvinte determinado, encontra-se na obrigação de inventar, na cena, o dispositivo de escuta que possibilitará seu relato "criando a necessidade de uma auto-mise-en-scène do personagem". ${ }^{21}$ Rafael é, talvez, quem mais escancara que a ausência do outro (seja o morador ou a equipe de filmagem) provoca uma fala que se volta para o si mesmo, imprimindo ao seu discurso um certo fluxo de consciência resultante de sua 
experiência na casa de Eliane Lacerda.

Já ao início de sua gravação, em uma sala em plano geral, ouvimos suas palavras: "primeira impressão". Aproxima a zoom de uma gravura onde há muitos rostos e ao centro, em tamanho maior, um negro com a boca aberta que parece gritar. Rafael fecha a lente nessa boca aberta e diz: "o que falar". (Nesse momento, na tela ao lado, Eliane fecha a zoom na figura de um menino, talvez Rafael quando criança, e também faz um close nos olhos e, depois, na boca dele que está fechada). Atende ao telefone, dá o seu próprio número dizendo ao interlocutor do outro lado da linha que é onde poderá falar com Eliane. Entra no banheiro filmando a si próprio através do espelho. Caminhando mais e mais em direção a ele até ter somente sua figura no campo de visão. Ele está de calção, sem camisa e de pés descalços.

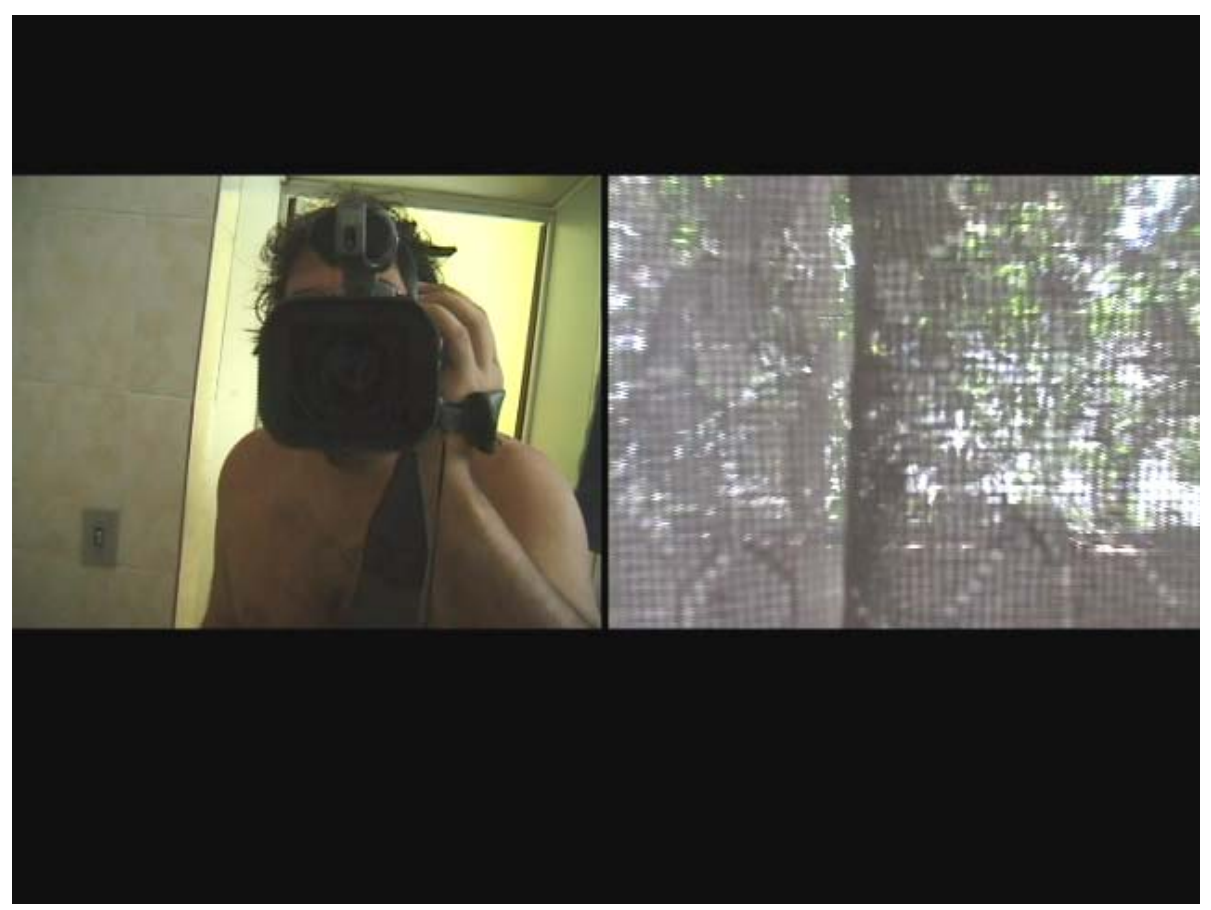

Grava o som de seu xixi, dá descarga, mexe nos móbiles e enquanto foca uma pintura à la Monalisa com as feições de uma outra mulher (que, depois, teremos 
certeza ser Eliane) e pergunta: “será ela a Monalisa?”. Filma o relógio algumas vezes e o passar do tempo, do seu tempo lá dentro. Vemos sua sombra e sua mão a cada porta que abre ou interruptor de luz que acende e apaga. Se mostra simulando dormir. "Acorda" e levanta abruptamente desestabilizando a imagem-câmera. Vê uma foto com três pessoas e diz: "Chute? A do meio, mas ainda tenho minhas dúvidas". Coloca a câmera sobre algum móvel e entra em quadro para sentar no sofá e ler o jornal.

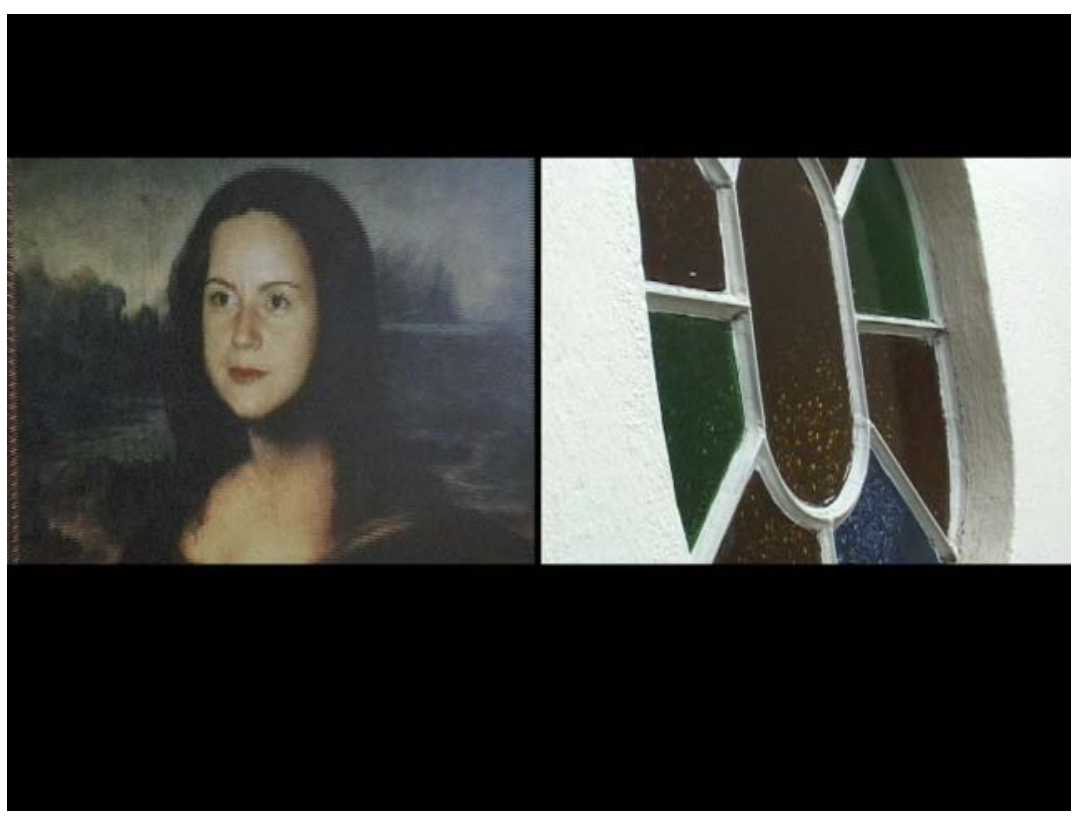

Como em suas imagens, no momento de sua entrevista-depoimento começa também falando que sua "primeira impressão" de sua anfitriã foi a de "ser uma pessoa que gosta de coisas". Descobriu em pouco tempo que era uma mulher, "foi fácil!", e "advogada pelo tanto de livros de direito que tem ali". E, após arriscar algumas características físicas de alguém que tem certeza ser mulher diz que é difícil ficar falando de alguém que não conhece e passa a falar de si, de como, apesar de ter tentado, não conseguiu me sentir em casa. 
Por outro lado, essas expressões subjetivas também podem ser lidas nas formas de registro como a de Paulo Dimas, por exemplo, que intervém no espaço alheio e compõe cenários com as roupas que acha pelo caminho para estetizar a gravação das revistas pornôs encontradas na casa de Mauro. Ou simulando uma masturbação com movimentos na câmera diante de uma foto de mulher nua.

Em uma caminhada no pátio na casa de Rafael, Eliane Lacerda filma os próprios pés em movimento, gesto que marca a presença do "eu" como construtor dessas imagens. Suas captações no interior da casa do produtor musical são as que mais persistem em um mesmo estilo. Ela aciona a zoom na maior parte do tempo e tenta chegar o mais próximo possível dos objetos encontrados na casa, mas o foco automático faz com que a aproximação excessiva dilua a nitidez da imagem, obrigando-a a recuar e abrir um pouco mais a lente, procurando a boa distância na focalização do que quer mostrar. Sua gravação é marcada por um vai-e-vem desse jogo de lentes buscando as imagens-vestígio que lhe ajudem na composição imaginária daquele que a recebe.

Assim, sejam as personagens mais ou menos silenciosas, as gravações dos participantes de Rua de mão dupla portam e atestam a alma do instante da tomada; sua amadora opacidade. A câmera-prótese que adere ao corpo da personagem e dá vazão "a arte da mão e da palavra", para retomar as metáforas de Roth, instrumento de auto-expressão de estéticas e de narrativas identitárias (urbanas) que, nessa perspectiva, flertam com relatos documentais em primeira pessoa.

Ao propor aos participantes de Rua de mão dupla a troca de casas Cao Guimarães os leva a vivenciar, nesse desterro em espaço urbano, uma experiência radical. Além de consentir que sua própria casa seja ocupada e devorada pelas 
imagens do "bisbilhoteiro" desconhecido, a pessoa deverá permanecer solitária, em espaço alheio, cumprindo ela também as vezes de detetive. Na performance de seus registros videográficos, desenvolverá uma narrativa própria àquele espaço e, portanto, a sua lógica de sentidos nessa investigação.

Há um enquanto isso presente no acontecimento da proposta documental que tempera tanto os momentos de filmagem como, posteriormente, a fruição da obra por parte do espectador. "Um de olho no outro", como diz a capa da revista que Paulo filma demoradamente na casa de Mauro. Enquanto estou aqui devassando essa casa em atitude vicária, esse outro também está de olho em mim, dentro do meu espaço e de minha intimidade, talvez indo ainda mais longe do que eu em sua procura de indícios.

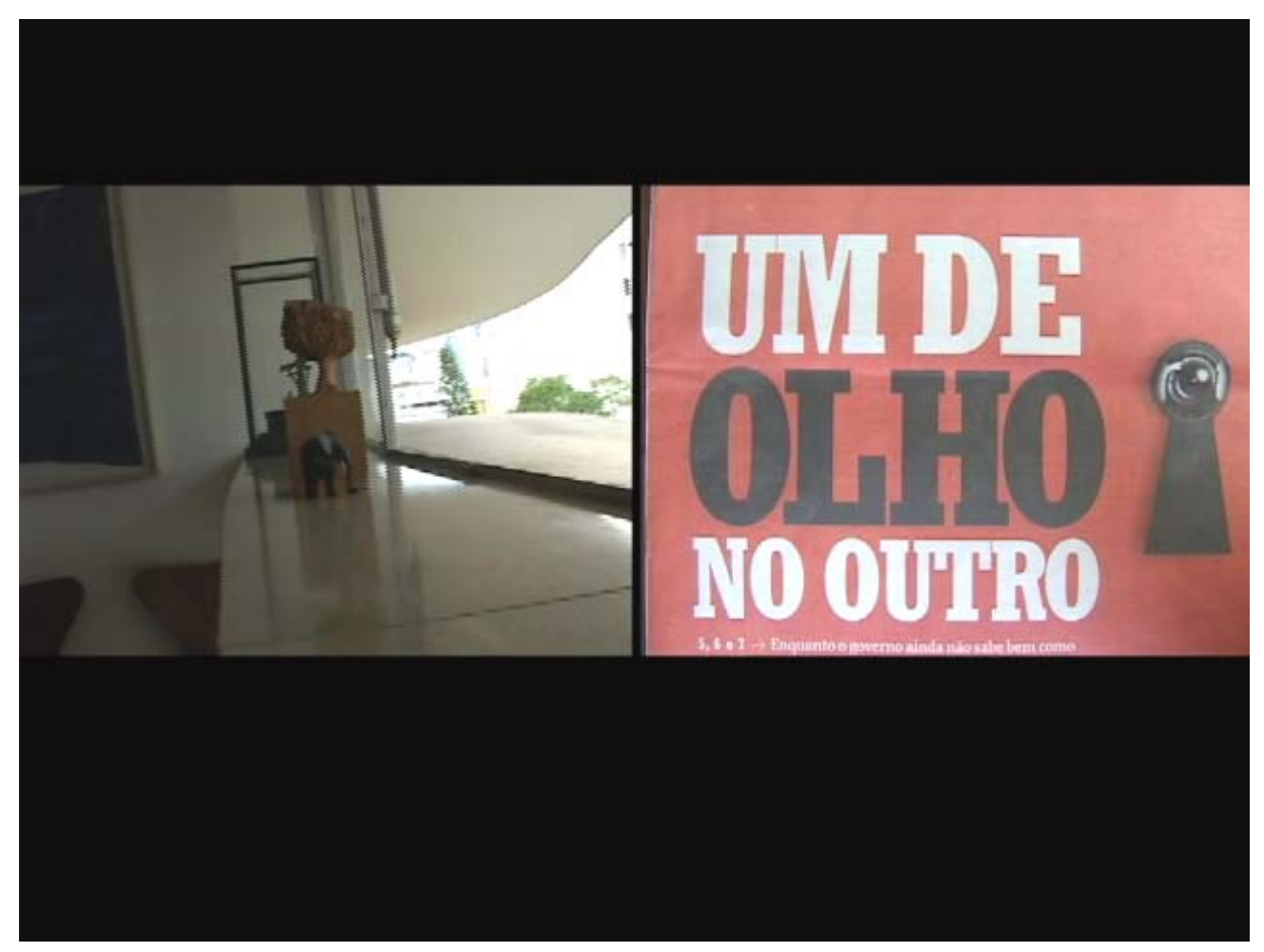

A proposta de afastar-se do seu universo para submergir no espaço alheio 
flerta com a idéia de "colocar-se no lugar do outro", de apreender, de dentro de seu espaço material e simbólico, sua lógica de mundo. Deslocamento que tangencia também a idéia da viagem, não apenas física, mas conceitual. Uma "viagem xamânica" e vertical que tem como norte o distanciar-se de si mesmo para aproximar-se do desconhecido. Intenção que, a princípio, estimularia a uma relativização dos próprios valores no embate com as concepções de mundo do outro.

Porém, em Rua de mão dupla o outro está, fora de campo, mas presente como uma "figura de ausência" 22, como um fantasma do seu próprio espaço entregue às mãos do visitante. Assim, um dos pontos mais interessantes dessa relação das personagens parece mesmo ser a do encontro que nunca acontece, a não ser a partir do espaço, dos objetos e da ausência do outro. Ou seja, a relação (de alteridade), de encontro e negociação com a diferença - com o outro e com o si mesmo -, se dá a partir da mais completa solidão. Mas o interessante aqui é que, de alguma maneira, se estabelece uma sociabilidade documental ausente no encontro da personagemcâmera com o mundo do outro, com esse outro imaginário e imaginado. Ausência que reendereça o outro para si mesmo, para uma sensibilidade apurada de suas próprias sensações em espaço alheio, para um estranhamento do si mesmo e do outro desde seu espaço mais íntimo e, a princípio, inviolável.

Rafael sentiu essa experiência do desterro e do "fora do lugar" com tal intensidade que "parecia estar na casa de um amigo em São Paulo", pois, segundo ele, faltou aquele "se sentir em casa". Já Eliane sintetiza em sua fala como a experiência acabou por provocar não só o estranhamento do outro, mas do si mesmo. Diz ela: 
A experiência é inusitada. É uma experiência única. É de estranhamento no começo e depois a gente vai se adaptando. Depois na hora de dormir dá aquela estranheza de novo, tanto que eu acordei várias vezes durante a noite sem saber onde eu estava. E dá uma certa solidão e um pouquinho de opressão.

Mauro, que fez dobradinha com Paulo, chegou animado, mas, aos poucos, cresce à medida que sua intolerância com o mundo do estrangeiro e a rejeição aos seus códigos de existência, sobretudo do seu espaço e dos seus hábitos, foram crescendo, ele foi se sentindo mais e mais incomodado.

(...) eu cheguei bem animado mesmo porque a gente tinha feito um aquecimento antes, mas depois eu não sei se foi o cheiro da roupa lavada (...) e também o barulho excessivo que tem aqui. (...) Têm horas que por essa sala passam 10 ônibus seguidos entram aqui por esse corredor, saem pelo banheiro, entendeu? Motocicletas passaram várias aqui, carro da polícia, ambulância.

Da mesma maneira Eliane Marta, que parecia animada com a vivência, "é genial muito rica, eu acho que me desfez alguns preconceitos sérios que eu tinha", vai pouco a pouco desconstruindo sua fala e mostrando total intolerância com o espaço e o cheiro do outro:

$\mathrm{Na}$ casa o que me afetou inicialmente foram os cheiros. Toda a casa tem seus cheiros e essa tinha um cheiro muito particular. Quando eu cheguei no quarto foi muito repulsivo. Senti um cheiro muito ruim que eu 
não identifico como o cheiro do outro. Eu disse que é cheiro de algo. Eu não sei o que é. O cheiro do outro, talvez. E foi impossível ficar naquele quarto.

Por essa perspectiva, no corpo a corpo com o território alheio, com seus móveis, seus cheiros, suas regras de higiene e organização que se dá o embate e o reconhecimento das diferenças urbanas. Processo que engendra o estranhamento do outro e do si mesmo, num jogo de descobertas e comparações que muitas vezes geram "conflito culturais", preconceitos e até mesmo hostilidades ${ }^{23}$ evocadas nos depoimentos dos participantes citadinos.

Mas eis aí outra grande contribuição do dispositivo de Rua de mão dupla em sua aproximação com a cidade, mostrar o quanto temos a tendência a ser, em nossa banalidade cotidiana, arraigados a nossos valores, "sempre classificando e rotulando de acordo com os princípios básicos através dos quais fomos socializados"24 e, portanto, o quanto nos é difícil reconhecer, assimilar e negociar com a diferença e com o diferente sem tentar simbolicamente domesticá-lo reduzindo-o aos nossos padrões culturais. Em alguns momentos, essa intolerância em relação à diferença se instaura em uma rua de mão dupla, em discursos simetricamente opostos, e as pessoas passam a falar do outro tão focadas nelas mesmas que reforçam os traços de sua própria personalidade.

Mauro, que é construtor, mapeou em sua gravação o espaço físico da casa de Paulo que, precisamente, identificou como sendo um arquiteto.

\footnotetext{
${ }^{23}$ LINS, Consuelo observa que "a montagem precisa" dispõe as duplas de maneira que "há uma hostilidade crescente da primeira para a terceira dupla". Op.cit.
} 
Bem eu estou entrando na casa do meu hóspede; hóspede, não, anfitrião. Casa completamente louca. Dá pra perceber... esse louco que eu falo no bom sentido, não é? Tem muita arte, muita coisa bonita né? Como dá pra perceber que é um dos prédios mais chiques de Belo Horizonte, edifício Niemayer, aqui na Praça da Liberdade e pelo tipo de móveis, mobiliário e dá pra perceber trata-se de uma pessoa de muito bom gosto, talvez um arquiteto. Esse quadro maravilhoso. Sala, móveis entrando no escritório, tem vários livros. Livros, som, violão que eu já experimentei.

Um discurso entre neutro e simpático, em um primeiro momento, vai dando lugar a um mau humor crescente não só em relação à arquitetura modernista ${ }^{25}$ como ao espaço em si e à própria interpretação que ele faz de Paulo a partir dos indícios recolhidos em sua casa. Em seu depoimento ao diretor, ao final das 24 horas, sua fala já tem outro tom.

Eu inicialmente queria falar sobre o local, o ambiente que essa pessoa vive. Ambiente assim bem diferente do normal. Um prédio todo torto, cheio de curvas, as paredes são tortas enfim é um negócio meio doido assim que eu pelo menos não estou acostumado com esse tipo de edificação. É uma obra famosa, mas bem difícil de se conviver, dentro dela. Pelo menos dentro dos meus parâmetros de habitabilidade, digamos assim.

Na mesma direção Paulo mostra-se mais sarcástico em relação ao estilo de vida de Mauro a quem enquadra em um padrão médio. Faz mordazes críticas ao prédio e ao bairro os quais, supõe, não combinam com seu anfitrião que tem lá suas

${ }^{24}$ VELHO, Gilberto. Individualismo e cultura. Rio de Janeiro: Jorge Zahar Editor, 1999. p.128.

${ }^{25}$ LINS, Consuelo. Op.cit. 
belezas. Aparentemente à vontade professa seu veredito:

(...) esse lugar aqui é um bairro classe média, um prédio classe média, de revestimento classe média de média. Esse prédio aqui poderia estar em diversos outros bairros de $\mathrm{BH}$ ou de outra cidade onde estivesse cercado pelas favelas. É um prédio padronizado e uniformizado igual esse é engraçado que ainda dá pra você encontrar pequenas belezas escondidas onde era mais inusitado estar. E a presença dele nesse prédio aqui é inusitada. Ele é um personagem que não combina com esse prédio. Ele devia estar morando em outro lugar. Ele devia estar morando em outro lugar há pouco tempo e aqui pode ser uma passagem. Pode ser um lugar que ele está porque a vida deixa ele estar por aqui, ele mora com conforto, tem segurança, não tem muita janela em volta... já tô misturando personagem com ele mesmo. Acho que esse cara queria morar num outro lugar, se pudesse.

Após ter revirado a casa de Mauro, abrindo gavetas e repertoriando com as imagens as revistas e filmes pornôs que encontrou pelo caminho chegando até mesmo a simular uma masturbação com a câmera diante da foto de uma mulher nua, Paulo usou esse caminho para descrever o anfitrião. Diz ele:

Essa pessoa é um homem grande, macho e, por religião, desde criança ele torce pro glorioso clube atlético mineiro.(...) Eu compus ele com barba, no mínimo bigode. Se ele pudesse ele usava chapéu na cidade, mas ele usa mais quando viaja.

O que ele gosta mais na vida é de pescaria e mulher pelada. (...) Bem, ele está sozinho, ocupando esse apartamento aqui há pouco tempo. Eu não sei se ele se separou há pouco tempo. Não tá com mulher aqui não porque a zona é tipicamente macha. 
A essa imagem "macha", professada pelo visitante Paulo em cima da cama de seu, Mauro contrapõe com seu próprio retrato de Paulo: uma pessoa solitária e pouco chegada a mulheres, em um verdadeiro duelo de opiniões. Diz ele:

É uma pessoa culta, parece ser um arquiteto, diria até professor (...) e parece também ser uma pessoa bem solitária, ela vive muito só. Não vi nenhum vestígio de presença feminina na área, há uma ausência de Anita total.(...) Tem aqui um mobiliário mais moderno, até contrastando com o ambiente... mas me pareceu uma pessoa muito solitária, tem acho que seis travesseiros na cama. Aquilo representa... já que não tem uma pessoa vamos colocar travesseiro e dormir abraçados neles, etc. Também uma pessoa despojada, não se preocupou em esconder nada, as coisas estavam todas expostas. Eu não sou muito curioso não quis mexer, mas o pouco que eu estive a observar me demonstrou isso aí.

Eliane Marta é talvez a personagem que mais transmite uma atitude blasé26 em suas gravações e depoimentos. É também quem mais parece ter condições intelectuais de articular, em ato, conceitos e critérios de classificação e qualificação do outro que ela chamou de "alguém". Porém, é também quem mais destila preconceitos e transmite um certo despreparo para a intensidade da experiência tornando-se uma personagem quase caricata nesse sentido. Atitude que fica mais evidenciada em confronto tanto com a visível diferença social entre ela e sua dupla, como também pelo depoimento de seu anfitrião, Paulo Renato, impactado com esse novo mundo propiciado pelo filme e para ele.

Eliane Marta estrutura sua fala a partir do princípio da ambigüidade e da

${ }_{26}$ SIMMEL, Georg. A metrópole e a vida mental. In: VELHO, Otávio (Org.). O fenômeno urbano. Rio de 
contradição, argumentos que movem o seu olhar em direção ao morador da casa em que está passando esse tempo. E se incomoda com essa duplicidade, fruto de sua interpretação: “(...) é um personagem muito estranho pra mim que acho que sou toda coerente, que se alguém entra na minha casa e sabe direitinho o que eu sou (...)". É também quem mais se incomoda com a precariedade e carências de infra-estrutura do espaço do outro:

Tudo me faz pensar... que se a gente pensar que a palavra morar vem de mores, costumes, que costumes são esses dessa pessoa que não tem gás na casa dela? Tem uma cozinha, tem uma mísera latinha pra fazer um foguinho com álcool e não dá pra fazer comida nenhuma. No entanto, tem uma panela, tem comida pro cachorro, tem arroz pronto... então é uma personagem muito contraditória essa que mora mal e tem maus costumes. E eu não acho que ele mora mal porque é pobre, não. Não sei se é pobre não. E também não é despojado.

Acho que ele é desprovido de idéia, de bom gosto, de atenção com ele mesmo.

Mas é essa personagem desprovida de idéia e bom gosto quem nos traz um outro retrato da cidade inscrita em seus gestos, em seu corpo e na forma como expressa sua vivência em Rua de mão dupla. Como os outros participantes ele também embasa seu olhar nas carências, diferenças e precariedades dos mundos. Porém, às avessas, confrontado com a abundância do mundo do outro. Conta que chorou, que ficou emocionado pensando no que estava vivendo e em sua fala constrói uma personagem que adere de maneira diferenciada às propostas do filme.

A ausência da outra pessoa ao mesmo tempo assim tanto detalhe, tanta coisa pra buscar. Mil universos diferentes. Diversidade aqui 
dentro. (...) A princípio me pareceu uma pessoa, assim, gorda, mas depois eu fui vendo que talvez ela não coubesse aqui no meio de tanta coisa, teria que ser uma pessoa mais culta, mais fina, que come pouco. O arroz integral na geladeira, regimes, né? A cama pequena. Eu dormi aqui na sala. Eu fiquei emocionado de manhã, chorei muito, fiquei triste, né? Fiquei imaginando essa pessoa na minha casa com tanta carência e eu aqui no meio de tanta coisa sem nem conseguir utilizar todas as coisas. Fiquei pensando assim o que que significa essa intimidade da gente dentro do ambiente de outra pessoa. Achei muito sensacional sentir essa qualidade de expectativa, de tentativa de harmonizar o meu eu com o eu de outra pessoa que eu nem conheço. (...) Cada detalhe do universo descobria identidades, as roupas, as caras, o telefone que tocava. $A$ geladeira, o fogão, a água. O ambiente externo. Como que pode ser isso, né? O que representa isso nesse momento do mundo pra arte, pras linguagens... você abrir a porta de sua casa e deixar uma pessoa entrar e conviver com você ausente. O que significaria isso pro mundo, pra humanidade. Deu um certo medo assim de tocar nas coisas, de se expor, de deixar as marcas ao mesmo tempo uma curiosidade muito grande de me sentir preso aqui dentro e livre ao mesmo tempo. Livre nessa expressão, nessas expressões que aqui dentro eu achei. Aí eu passei mal. Fiquei com dor de cabeça de tanto pensar. Fiquei olhando as portas antigas. Vendo recordações de família. Quem seria, quem seriam? Perguntome. (...) As pessoas deveriam fazer isso né, de vez em quando. Gostei muito da experiência.

A estética do estranhamento atravessa os dispositivos de realização, interação e exibição de Rua de mão dupla e faz do interior um espelho de onde se reflete o exterior. Até mesmo na sociabilidade às avessas vivenciada pelas personagens na ausência do outro, Rua de mão dupla é um documentário repleto de urbanidade. A um só tempo traz a solidão, o estranhamento ao diferente e à diferença, espírito que rege as redes de relações das grandes cidades brasileiras do qual a narrativa se contamina. 


\section{CONCLUSÃO}

No percurso deste trabalho, analisamos documentários contemporâneos sob a perspectiva da inscrição dos imaginários urbanos engendrados em suas formas de narrar as cidades brasileiras. Ainda que com uma dimensão bastante arbitrária, tendo em vista que muitos outros filmes poderiam ter sido convocados para essa análise, pautamos nossa seleção com o intuito de mapear um determinado campo documental que espelhasse as diversidades estilísticas e éticas na produção recente.

Partimos da hipótese de que os dispositivos de interação empregados pelos documentaristas configuram sociabilidades documentais, moduladas em relações de proximidades e distâncias que expressam o estar junto nas imagens e por causa delas. Sociabilidades que apontam às formas de partilha do espaço narrativo que tanto se abrem à fabulação criadora ou que, ao contrário, tentam domesticá-la em proveito de um efeito de veracidade. Jogo entre o cristalino e o orgânico, como intuiu Deleuze, sempre presente no horizonte das narrativas (audiovisuais).

Com esses pressupostos, preocupamo-nos em afirmar nossa percepção do documentário como um encontro (e confronto) maquínico entre culturas diferentes. Um encontro instaurador de dispositivos técnicos e conceituais que se nutre de um 
imaginário coletivo ao mesmo tempo em que a ele incorpora-se como imagem. A partir da perspectiva da presença da máquina na relação entre o sujeito e o real, para retomarmos a expressão de Dubois (cf. capítulo 1), conferimos uma gênese à sociabilidade documental nas tradições modernas inauguradas pelo cinema verdade francês e o direto norte-americano. Vimos que ali se instauram corporeidades que contaminam as formas do encontro, estabelecendo reciprocidades e assujeitamentos no jogo documental.

As revoluções tecnológicas e os pressupostos conceituais almejados pelas novas tradições transmutam o "olhar sem corpo"1 das vanguardas de 30 em uma câmera-corpo naqueles prenúncios dos anos 60 , quando a publicidade, a mídia e os dispositivos de vigilância ainda tinham uma presença tênue no cotidiano dos grandes centros urbanos. De maneiras diversas, construindo um campo documental rico e tensionado, o corpo do documentarista, seja ele um corpo-câmera ou um corpo que se oferece como imagem diante das câmeras, engendra um processo de comunicação e íntima inter-relação com o outro.

Constrói-se, a partir disso, um cinema como afirmação do presente e da presença, ainda que de uma presença-corpo discreta, sempre depurada de intervenções e permeada por silêncios, como quis a linhagem de Drew. Em sentido oposto, a tradição do nascente cinema verdade francês propõe sua presença em cena. Os realizadores se transformam em personagens, trazendo o processo da realização documental ao centro do acontecimento narrativo.

No nosso entender, Edifício Master, Ônibus 174 e Rua de mão dupla retomam,

\footnotetext{
${ }^{1}$ Cf. XAVIER, Ismail. Cinema: revelação e engano. In: NOVAES, Adauto (Org.). O olhar. São Paulo: Companhia das letras, 1989. p. 367-384.
} 
de maneira impura e híbrida, o espírito dessas diferentes modulações de proximidade e partilhas urbanas instauradas pelos modernos. As análises desenvolvidas nesta obra possibilitaram ao leitor um cotejo nos desdobramentos, recriações e até mesmo padronizações nas formas de estar presente e de construir relações nas imagens e por causa delas. Em Edifício Master, encontramos o espírito do cinema verdade na estética da proximidade intercessora, na palavra encarnada e na aderência ao regime cristalino. Ônibus 174 filia-se, em chave estético-conceitual, aos preceitos de distância do cinema direto norte-americano, pautando-se pelo regime orgânico ancorado no efeito de verossimilhança. Rua de mão dupla, entretanto, ao operar com dispositivos de interação em registro misto, subverte e desloca a estabilidade das equações (orgânico versus cristalino, proximidade versus distância), fragilizando possíveis dicotomias. A um só tempo, o imaginário da presença, o efeito de distância entre o realizador e suas personagens, bem como a fabulação, impõemse em todas as instâncias do documentário.

Recolocando a observação de Deleuze $^{2}$ em relação ao esfumaçamento das fronteiras entre ficção e documentário no cinema moderno, diríamos que nessa linhagem do documentário com a arte contemporânea, pelo menos à qual se filia Cao Guimarães, a distinção já não se dá mais entre os efeitos possibilitados pela aderência aos regimes cristalino ou orgânico, mas de um novo modo narrativo que afeta os dois, em que um intercede junto ao outro, em um jogo de contaminações e ressignificações. Colocação que permite até mesmo uma reflexão mais abrangente sobre estatuto, sempre imaginário, dos fluxos das imagens que povoam a vida

\footnotetext{
2 Cf. nota 71 do capítulo 2.
} 
contemporânea.

Acreditamos que esses filmes expressam, cada um a seu modo, certa atmosfera do vivido, e que, em suas exibições ao público, ajudam a formar novos imaginários do sentimento coletivo do viver nas cidades na atualidade. Propusemos que Coutinho desenvolve uma sociabilidade da presença para devolver-nos uma cidade fabulada e imaterial. Privilegia a performance e a desenvoltura de suas personagens e impõe ao espectador, desde sua maestria narrativa, uma constante relativização dos dramas narrados. Ônibus 174 opta por uma sociabilidade distanciada, investindo em recursos que resultem, em chave melodramática, em uma ordenação narrativa do descontrole da violência urbana. Por fim, Rua de mão dupla desenvolve uma sociabilidade às avessas, com a presença ausente de um outro imaginário, e deixa emergir, em tom de uma indiferença que roça o blasé, as intolerâncias ao diferente que orquestram o sentimento dos habitantes urbanos.

Sem dúvida, o século XXI se desenha com relevância em relação à imagem no cotidiano das grandes cidades - simultânea e indissociavelmente - como lugar privilegiado de inscrição, modelagem e exacerbação de nosso imaginário urbano. A câmera-corpo transmuta-se em câmera-prótese, "a câmera da mão e da palavra", como coloca Roth (cf. capítulo 6), engendrando renovadas formas de vincularmo-nos ao mundo e ao outro, de acionarmos formas de sociabilidade pela imagem e por causa dela. 


\section{BIBLIOGRAFIA}

ALMEIDA, Luís Silva de. Hermenêutica filosófica: nas trilhas de Hans-Georg Gadamer. Porto Alegre: EDIPUCRS, 2000.

ALTHABE, G. ; COMOLLI, J.L. Regards sur la ville. Paris: Centre Georges Pompidou, 1989.

AUMONT, Jacques. A imagem. Campinas: Papirus, 1993.

AUMONT, Jacques. $O$ olho interminável (cinema e pintura). São Paulo: Cosac\&Naify, 2004.

BARNOUW, Erik. El documental: historia y estilo. Barcelona: Gedisa, 1996.

BHABHA, Homi. O local da cultura. Belo Horizonte: Editora da UFMG, 1998.

BELLOUR, Raymond. Entre-imagens. Campinas: Papirus,1997.

BENJAMIN. Walter. Obras escolhidas (1). Magia e técnica, arte e política. São Paulo: Brasiliense, 1985.

BERNARDET, Jean- Claude. Caminhos de Kiarostami. São Paulo: Companhia das Letras, 2004.

BERNARDET, Jean- Claude. Cineastas e imagens do povo. São Paulo: Companhia das Letras, 2003.

BEZERRA DE MENEZES, Adélia. Do poder da palavra. Folha de S. Paulo, São Paulo, 29 jan. 1988.

BONITZER, Pascal. Peinture et cinema: Décadrages. Paris, Cahiers du cinema/Editions de l'etoile, 1995.

BONITZER, Pascal. La surimage. Cahiers du cinéma, Paris, n. 270, sept.-oct., 1976. 
BOURDIEU, Pierre. Esboço de auto-análise. São Paulo: Companhia das Letras, 2005.

BOURDIEU, Pierre. Raisons pratiques, Sur la théorie de l'action. Paris: Éd. du Seuil, 1994.

BOURDIEU, Pierre. A ontologia politica de Martin Heidegger. Campinas: Papirus, 1989.

BRESCHAND, Jean. Le documentaire: l'autre face du cinéma. Paris: Cahiers du cinéma, 2002.

BURCH, Noel. Práxis do cinema. São Paulo: Perspectiva, 1992.

CALDEIRA, Teresa Pires do Rio. Cidade de muros: crime, segregação e cidadania em São Paulo. São Paulo: Editora 34/EDUSP, 2000.

CANNABRAVA, Iatã; MONTEIRO, Rachel; MÜLLER, Jurandir (Coords). Povos de São Paulo. São Paulo: Editora Terceiro Nome, 2004.

CINEACTION. 1995. Annes 90: où en est le cinema direct?

CARDOSO DE OLIVEIRA, Roberto. A categoria da (des)ordem e a pós-modernidade da antropologia. Campinas: Unicamp, 1987. Trabalhos em Antropologia 1

CHARNEY, Leo; SCHWARTZ, Vanessa. O cinema e a invenção da vida moderna. São Paulo: Cosac\&Naif, 2001.

CLIFFORD, James. A experiência etnográfica: antropologia e literatura no século XX. Rio de Janeiro: Editora UFRJ, 1998.

COMOLLI, Jean-Louis. A cidade filmada. In: Cadernos de Antropologia e imagem. v. 4: A cidade em imagens. Rio de Janeiro: UERj, 1997.

COSTA, Ricardo. A outra face do espelho. Jean Rouch e o "outro"'. Disponível em <http:/ / / bocc.ubi.pt/pag/costa-ricardo-jean-rouch.html>.

COUTINHO, Eduardo. A astúcia. In: NOVAES, Adauto (Org.). Rede Imaginária. São Paulo: Secretaria Municipal de Cultura/Companhia das Letras, 1991.

CRAPANZANO, V. Diálogo, In: Anuário Antropológico/88. Brasília: Editora da UnB, 1991.

DANEY, Serge. Perseverance: entretien avec Serge Toubiana. Paris: P.O.L., 2003.

DA-RIN, Sílvio. O espelho partido. Tradição e transformação no documentário. Rio de Janeiro: Azougue editorial, 2004.

DE CERTEAU, Michel. A invenção do cotidiano (1). Artes de Fazer. Rio de Janeiro: Vozes, 1994. 
DE CERTEAU, Michel. A invenção do cotidiano (2). Morar. Cozinhar. Rio de Janeiro: Vozes, 1994.

DELEUZE, Gilles. A imagem-tempo. São Paulo: Brasiliense, 1990.

DELEUZE, Gilles. Conversações. São Paulo: Editora 34, 2000.

DUBOIS, Philippe. Vídeo, cine, godard. Buenos Aires: Libros del Rojas/ Universidade de Buenos Aires, 2001.

DURAND, Gilbert. A imaginação simbólica. São Paulo: Cultrix/ Editora da Universidade de São Paulo, 1988.

DURAND, Gilbert. As estruturas antropológicas do imaginário. Lisboa: Editorial Presença, 1989.

DURAND, Gilbert. As estruturas antropológicas do imaginário. São Paulo: Martins Fontes, 2002.

ECKERT, Cornélia; ROCHA, Ana Luísa. Jean Rouch e os encontros e confrontos da sociedade ocidental com alteridade/diferença pelos olhos de um contador de histórias. In: ZANINI, Maria Catarina Chitolina (Org.). Santa Maria: Editora da UFSM, 2007.

Eckert, CORNÉLIA; Rocha, ANA LUÍSA. Les enjeux du temps moderne: ville et cinéma. In: Filmer la ville. Premières rencontres anthropo-cinématographiques de Besançon UFR Lettres et Sciences Humaines, Section d'Anthropologie et de Sociologie. France: Besançon, 2002.

FLICKINGER, Hans Georg. Hermenêutica filosófica: nas trilhas de Hans Georg Gadamer. Porto Alegre: EDIPUCRS, 2000.

FOUCAULT, Michel. As palavras e as coisas. Portugal: Edições 70, 1988.

FRANÇA, Andréa. Encenado papéis (ou o espaço do jogo em dois documentários). Revista Sinopse, São Paulo, USP, n. 11, set. 2006.

FRANÇA, Andréa. Terras e fronteiras no cinema político contemporâneo. Rio de Janeiro: 7 Letras, 2003.

GAUTHIER, Guy. Le Documentaire un autre cinéma. Paris: Armand Colin, 2005.

GEERTZ, Cliford. A interpretação das culturas. Rio de Janeiro: Zahar, 1989.

GEERTZ, Cliford. O conhecimento local. Petrópolis: Vozes, 1999. 
GERVAISEAU, H. O Abrigo do tempo. Abordagens cinematográficas da passagem do tempo e do movimento da vida dos homens. Tese (Doutorado em Comunicação), Rio de Janeiro: ECO/UFRJ, 2000.

LABAKI, Amir. O cinema do real. São Paulo: Cosac\&Naif, 2005.

LABAKI, Amir. É tudo verdade: reflexões sobre a cultura do documentário. São Paulo: Francis, 2005.

LAVIA, Jairo. As feridas abertas do Ônibus 174. Revistaparadoxo. Disponível em: <http:/ / www.revistaparadoxo.com.br>

LEITE, R. P. Contra-usos e espaço público: notas sobre a construção social dos lugares na Manguetown. Revista Brasileira de Ciências Sociais, São Paulo, ANPOCS/Edusc, v. 17, n. 49, jul. 2002.

LINS, Consuelo. O documentário de Eduardo Coutinho - televisão, cinema e vídeo. Rio de Janeiro: Zahar, 2004.

LINS, Consuelo. Rua de mão dupla: documentário e arte contemporânea. Disponível em:<http://www.videobrasil.org.br/ffdossier/Ruademaodupla_ConsueloLins.pdf> MACHADO, Arlindo. A arte do vídeo. São Paulo: Brasiliense, 1988,

MACHADO, Arlindo. Máquina e imaginário. São Paulo: EDUSP, 1993.

MACHADO, Arlindo. Pré-cinemas E pós-cinemas. Campinas: Papirus,1997.

MACHADO Jr., Rubens. A polis ironizada: sobre a dimensão política do experimentalismo superoitista. In: CARDENUTO Filho, Reinaldo (or,). Golpe de 64: amarga memória. catálogo. São Paulo: Centro Cultural São Paulo.

MAFFESOLI, Michel. No fundo das aparências. Petrópolis: Vozes, 1999.

MAGNANI, J. G. C. De perto e de dentro: notas para uma etnografia urbana. Revista Brasileira de Ciências Sociais, São Paulo, ANPOCS/Edusc, v. 17, n. 49, p.11-29, jul.2002. MARIE, Michel. La nouvelle vague: une école artistique. Paris: Éditions Nathan, 1997. MARSOLAIS, Gilles. L'Aventure du cinéma direct. Paris: Seghers, 1973.

MAUSS, Marcel. Sociologia e Antropologia. v.II. São Paulo: Editora Pedagógica e Universitária Ltda./ Editora da Universidade de São Paulo, 1974.

MCDOUGALL, David. Au delà du cinéma d'observation. In: FRANCE, Claudine (Org.). Pour une anthropologie visuelle. Paris: Mouton Éditeur et École des Hautes Études en Sciences Sociales, 1979. 
MCDOUGALL, David. Transcultural cinema. New Jersey: Princeton University Press, 1998.

MESQUITA, C.; SARAIVA, L.(Orgs.). Mostra diretores brasileiros: Eduardo Coutinho, cinema do encontro. São Paulo: CCBB, 2002.

MORIN, Edgard e ROUCH, Jean. Chronique d'un été. Paris: Inter Spectacles, 1962.

MOURÃO, Maria Dora. A montagem no cinema direto. Socine, 2005.

MURCH, Walter. Num piscar de olhos. Rio de Janeiro: Zahar, 2004.

NATALI, Maurizia. L'image-paysage: iconologie et cinema. Saint-Denis: PUV, 1996.

NEVES, David. A descoberta da espontaneidade. In: Dossiê David Neves. Disponível em: <http: www.contracampo.com.br.>

NICHOLS, Bill. Introdução ao documentário. Campinas: Papirus, 2005.

NICHOLS, Bill. La representación de la realidad: cuestiones y conceptos sobre el documental. Barcelona: Paiadós Comunicación, 1991.

NINEY, François. L'épreuve du réel à l'écran: essai sur le príncipe de realité documentaire. Bruxelas: de boeck, 2000

PARENTE, André. Narrativa e modernidade. Campinas: Papirus, 2000.

PRYSTHON, Angela (Org.). Imagens da cidade: espaços urbanos na comunicação e cultura contemporâneas. Porto Alegre: Sulina, 2006.

PIMENTA, Carlos Henrique Gomes. Disponível em:

<http://www.mnemocine.com.br/aruanda>.

RAMOS, Fernão Pessoa (Org.). Teoria contemporânea do cinema: documentário e narratividade ficcional. v. II. São Paulo: Editora SENAC, 2005.

RAMOS, Fernão Pessoa (Org.). Teoria contemporânea do cinema: pós-estruturalismo e filosofia analítica. v. I. São Paulo: Editora SENAC, 2005.

RIVETTE, Jacques. De 1'abjection. Cahiers du cinéma, Paris, n.170, jun. 1961.

ROCHA, Ana Luísa. Antropologia das formas sensíveis: entre o visível e o invisível, a floração de símbolos. 2000.

ROCHA, Ana Luísa. Le sanctuaire du désordre, ou l'art de savoir faire des tenders bárbares sous les tristes tropiques. Ethude de l'esthétique urbaine et de la mémoire collective au sud du Brésil. Tese (Doutorado em Antropologia Social), Paris: Universidade René Descartes, Paris V, 2004. 
ROSSELLINI, Roberto. Le cinéma révélé. Textes Réunis e prefaces par Alain Bergala. Paris: Editions de l'etoile, 1984.

ROUCH, Jean. La caméra et les hommes. In: FRANCE, Claudine (Org.). Pour une anthropologie visuelle. Paris: Mouton Éditeur et École des Hautes Études en Sciences Sociales, 1979.

SATT, Maria Henriqueta. Circularidades e superfícies: uma leitura videográfica das imagens batuqueiras. Dissertação (Mestrado em Multimeios), Campinas: Unicamp, 1995.

SIMMEL, G. Sociabilidade - um exemplo de sociologia pura ou formal. In: MORAES, E. (Org.). Sociologia: Simmel. São Paulo: Ática, 1983. (Coleção Grandes Cientistas Sociais).

STAM, Robert. Introdução à teoria do cinema. Campinas: Papirus, 2003.

SOBCHACK, Vivian. Inscrevendo o espaço ético: dez proposições sobre a morte. IN.:

RAMOS, Fernão (Org.). Teoria contemporânea do cinema. v. I. São Paulo: Senac, 2005.

RENOV, Michel. New subjectivities: Documentary and Self-Representation in the PostVerité Age. Disponível em: < http://www.yidff.jp/docbox/7/box7-1-e.html>.

TEIXEIRA, Francisco Elinaldo (Org.). Documentário no Brasil. São Paulo: Summus, 2004.

VELHO, Gilberto. Individualismo e cultura. Rio de Janeiro: Zahar, 2002.

VELHO, Gilberto. Subjetividade e sociedade uma experiência de geração. Rio de Janeiro: Zahar, 2002.

VELHO, Otávio Guilherme (Org.). O fenômeno urbano. Rio de Janeiro: Editora Guanabara, 1987.

VERNET, Marc. De l'invisible au cinema: figures de l'absence. Paris: Cahiers du cinéma, 1988.

VIRILIO, Paul. La maquina de vision. Madrid: Cátedra, 1998.

XAVIER, Ismail (Org.): A experiência do cinema. Rio de Janeiro: Graal/Embrafilme, 1983.

XAVIER, Ismail. Cinema: revelação e engano. In: NOVAES, Adauto (Org.). O olhar. São Paulo: Companhia das letras, 1989. 
XAVIER, Ismail. Alegorias do subdesenvolvimento: cinema novo, tropicalismo, cinema marginal. São Paulo: Brasiliense, 1993.

XAVIER, Ismail. O cinema brasileiro moderno. Rio de Janeiro: Paz e Terra, 2001.

XAVIER, Ismail. O discurso cinematográfico: a opacidade e a transparência. Rio de Janeiro: Paz e Terra, 1984.

XAVIER, Ismail. O olhar e a cena. São Paulo: Cosac\&Naify, 2003.

XAVIER, Ismail. Documentário e afirmação do sujeito: Eduardo Coutinho, na contramão do ressentimento. Estudos de cinema SOCINE, São Paulo, ano IV. Panorama/Fapesp, 2003.

YOUNG, Colin. Le cinéma d'observation. In: FRANCE, Claudine (Org.). Pour une anthropologie visuelle. Paris: Mouton Éditeur et École des Hautes Études en Sciences Sociales, 1979.

ZALUAR, Alba. As imagens da e na cidade: a superação da obscuridade. Cadernos de Antropologia e Imagem, Rio de Janeiro, n.4, 1995.

WINSTON, Brian. Ethics. In: CORNER, John; ROSENTHAL, Alan (Orgs.). New challenges for documentary. New York, Manchester University Press, 2005. 


\section{FILMOGRAFIA}

A alma do osso, Brasil, 2004, direção de Cao Guimarães.

Aiguiller de tram, Canadá, 1954, direção de Roman Kroitor.

À margem da imagem, Brasil, 2002, direção de Evaldo Mocarzel.

América, Brasil, 1989, direção de João Moreira Salles.

À propôs de Nice, França, 1929, direção de Jean Vigo.

Babilônia 2000, Brasil, 2000, direção de Eduardo Coutinho.

As parteiras, Brasil, 2004, direção de Evaldo Mocarzel.

Au pays des mages noirs, França/Nigéria, 1947, direção de Jean Rouch.

Berlim, sinfonia de uma metrópole (Berlin: Die Symphonie der Großstadt), Alemanha, 1927-28, direção de Walter Ruttmann.

Bientôt Noël , Canadá, 1958, direção de Michel Braut, Georges Dufaux,

Macartney-Filgate, Wolf Koening.

Boca do lixo, Brasil, 1992, direção de Eduardo Coutinho.

Cabra marcado para morrer, Brasil, 1964-84, direção de Eduardo Coutinho.

Caso norte, Brasil, 1977, direção de João Batista de Andrade.

China, Brasil, 1987, direção de João Moreira Salles.

Cidade de Deus, Brasil, 2002, direção de Fernando Meireles e Kátia Lund.

Crônica de um verão, França, 1960-61, de Jean Rouch e Edgard Morin.

Don't look back (Bob Dylan), Estados Unidos, 1967, de D.A. Pennebaker.

Do outro lado da sua casa, Brasil, 1986, de Renato Barbieri, Marcelo Machado, Paulo Morelli.

Drifters, Inglaterra, 1929, direção de John Grierson.

Edifício Master, Brasil, 2002, direção de Eduardo Coutinho.

Entreatos, Brasil, 2004, direção de João Moreira Salles.

Eu, um negro (Moi un noir), França, 1958, direção de Jean Rouch.

Garrincha alegria do povo, Brasil, 1963, direção de Joaquim Pedro de Andrade. 
Gimme Shelter, Estados Unidos, 1970, direção de Albert e David Maysles e Charlotte Zwerin.

Grey gardens, Estados Unidos, 1975, direção de Albert e David Maysles.

Industrial Britain, Inglaterra, 1931, direção de Robert J. Flaherty.

Initiation à la danse des possédés, França, 1948, direção de Jean Rouch.

Integração racial, Brasil, 1964, direção de Paulo César Sarraceni.

Jaguar, França, 1954-67, direção de Jean Rouch.

Japão, uma viagem no tempo, Brasil, 1986, direção de Walter Salles.

Jardim nova bahia, Brasil, 1971, direção de Aloysio Raulino.

Krajcberg, o poeta dos vestígios, Brasil, 1989, direção de Walter Salles.

La chasse à l'hippopotame, França/Nigéria, 1951, direção de Jean Rouch.

La pyramide humaine, França, 1959, direção de Jean Rouch.

Liberdade de imprensa, Brasil, 1967, direção de João Batista de Andrade.

Maioria absoluta, Brasil, 1964-66, direção de Leon Hirszman.

Migrantes, Brasil, 1972, direção de João Batista de Andrade.

Moana, Estados Unidos, 1926, direção de Robert J. Flaherty.

Nanook of the north, Estados Unidos/Canadá, 1922, direção de Robert J.

Flaherty.

Nem gravata nem honra, Brasil, 2001, direção de Marcelo Masagão.

Nossa escola de samba, Brasil, 1964, direção de Manuel Horácio Gimenez.

Notícias de uma guerra particular, Brasil/Espanha, 1999, direção de João Salles e Kátia Lund.

Ônibus 174, Brasil, 2002, direção de José Padilha e Felipe Lacerda.

O invasor, Brasil, 2001, direção de Beto Brant.

O primeiro dia, França/Brasil 1998, direção de Daniela Thomas e Walter Salles.

O prisioneiro da grade de ferro, Brasil, 2003, direção de Paulo Sacramento.

Os mestres loucos, (Les maîtres fous), França/Gana, 1954, direção de Jean Rouch.

Povos de São Paulo, Vídeo Crônicas, Brasil, 2004, direção de Kiko Goifman.

Primárias, Estados Unidos, 1960, direção de Robert Drew e Richard Leacok.

Primeira visita dos Beatles aos EUA (The Beatles in the USA), Estados Unidos, 1964, direção de Albert e David Maysles. 
Rua de mão dupla, Brasil, 2004, direção de Cao Guimarães.

Ryan, Canadá, 2004, direção de Chris Landreth.

Santa Marta, duas semanas no morro, Brasil, 1987, direção de Eduardo Coutinho.

Santo Forte, Brasil, 1999, direção de Eduardo Coutinho.

São Paulo, terra do amor, Brasil, 1971, direção de Carlos Augusto Oliveira.

Shoah, França/Polônia, 1986, direção de Claude Lanzman.

Stromboli, Itália, 1949, direção de Roberto Rossellini.

Subterrâneos do futebol, Brasil, 1964, direção de Maurice Capovilla.

Tarumã, 1975, direção de Aloysio Raulino, Guilherme Lisboa, Mário Kuperman e Romeu Quinto.

Território vermelho, Brasil, 2004, direção de Kiko Goifman.

Um homem com uma câmera, União Soviética, 1929, direção de Dziga Vertov.

Viramundo, Brasil, 1965, direção de Geraldo Sarno.

We are the lambeth boys, Inglaterra, 1959, direção de Karel Reisz. 